Universidade de São Paulo

Faculdade de Filosofia, Letras e Ciências Humanas

Departamento de Ciência Política

\title{
PARTIDOS E POLÍTICAS NOS GOVERNOS SUBNACIONAIS BRASILEIROS
}

Paulo Cesar Pereira Loyola

São Paulo

2014 
Paulo Cesar Pereira Loyola

\title{
PARTIDOS E POLÍTICAS NOS GOVERNOS SUBNACIONAIS BRASILEIROS
}

\begin{abstract}
Dissertação apresentada ao programa de pósgraduação do Departamento de Ciência Política da Universidade de São Paulo como requisito para a obtenção do título de Mestre em Ciência Política
\end{abstract}

Orientadora: Profa. Dra. Marta Arretche 
Paulo Cesar Pereira Loyola

Partidos e Políticas nos Governos Subnacionais Brasileiros

Dissertação apresentada ao programa de pósgraduação do Departamento de Ciência Política da Universidade de São Paulo como requisito para a obtenção do título de Mestre em Ciência Política

Orientadora: Profa. Dra. Marta Arretche

Aprovado em:

Banca Examinadora

Prof. Dr.: Instituição:

Julgamento: Assinatura:

Prof. Dr.: Instituição: Julgamento: Assinatura:

Prof. Dr.: Instituição:

Julgamento: Assinatura: 
Para meus pais 


\section{AGRADECIMENTOS}

Sou grato à Professora Marta Arretche que orientou este trabalho com muita seriedade e dedicação. Suas críticas e sugestões acrescentaram muito ao resultado final desta dissertação. Devo muito à sua orientação o meu amadurecimento como pesquisador, que se refletiu neste trabalho.

A contribuição da Professora Lorena Barberia também foi determinante. Sua disposição em discutir esta pesquisa e em me auxiliar em questões metodológicas foram centrais ao desenvolvimento deste trabalho.

Minha banca de qualificação, composta pelos Professores Fernando Limongi e Lorena Barberia, também teve importante influência nos resultados de trabalho. Seus comentários levaram à elaboração de um novo desenho de pesquisa e trouxeram maior consistência aos achados desta pesquisa.

Também agradeço aos Professores George Avelino, Milan Svolik, Paula Louzano e Scott Greer que em algum momento encontraram tempo para ter conversas comigo e fazer comentários que foram muito importantes para este trabalho.

Aos meus colegas de grupo de estudos agradeço os comentários feitos a este trabalho em suas muitas fases anteriores e às estimulantes discussões das quais participamos: Diogo Ferrari, Edney Dias, Elize Massard, Fernando Marques, Murilo Junqueira, Patrick Silva e Rogério Schlegel. Também agradeço aos meus colegas interessados em teoria dos jogos: Rafael Magalhães, Ricardo Ribeiro e Vitor Oliveira. Obrigado também a Edgard Fusaro que me auxiliou em questões importantes referentes ao tratamento de meu banco de dados. Pelos comentários, conversas, por todo apoio recebido e pela amizade também agradeço Clara Oliveira e Maurício Izumi. Agradeço também Júlio Costa, Carolina Requena, Leandro Rodrigues, Telma Hoyler, Júlia, Márcia e João Farias pela amizade e por todo o apoio.

Agradeço a Joana Farias por todo o companheirismo e apoio. Tudo sempre foi melhor com você ao meu lado. Nestas poucas linhas não cabe minha gratidão a você.

Agradeço aos meus pais, Alaides e Paulo. Sem as oportunidades que me proporcionaram nada disto existiria.

Por fim, agradeço a CAPES e a FAPESP (processo $n$ ㅇ 2012/07001-0) pelo apoio financeiro e a todas as pessoas com as quais convivi nestes anos e que me deram forças para concluir mais esta etapa de minha vida. 
"Quando Newton formulou a lei da gravitação, não disse que o Sol ou a Terra tinham a propriedade de se atraírem mutuamente, disse que todos os corpos, do maior ao menor, se comportavam como se se atraíssem uns aos outros, isto é, deixando-se de lado o problema da causa do movimento dos corpos, enunciou uma propriedade comum a todos, do infinitamente grande ao infinitamente pequeno. As ciências naturais procedem da mesma maneira: abandonam a procura das causas para pesquisarem as leis. Também a História segue esse caminho. E se o objeto da História é o estudo do movimento dos povos, e não a descrição de alguns episódios da vida dos homens, ei-la que deve, afastando a noção das causas, procurar as leis comuns a todos os elementos infinitamente pequenos da liberdade, iguais, indissoluvelmente vinculados entre si e infinitamente pequenos"

(Leon Tolstói) 


\section{Resumo}

Ao observarmos como os partidos políticos se posicionam na arena federal, podemos perceber que eles se distinguem em relação às suas prioridades estabelecidas para as políticas públicas. Entretanto, não sabemos se estas prioridades, expressas por parlamentares na arena federal, traduzem-se em políticas quando seus respectivos partidos estão no controle do poder executivo local. Poucos estudos têm se dedicado à investigação da influência dos partidos políticos brasileiros sobre as políticas que são implementadas pelos governos subnacionais. O objetivo deste trabalho é dar uma contribuição para esta agenda de pesquisa mediante i) a apresentação de um modelo formal que simplifique e exponha as melhores opções dos prefeitos de diferentes partidos quando há preferências partidárias sobre políticas e quando estas preferências estão ausentes; e ii) a análise da política de educação desenvolvida pelos prefeitos e seus partidos. Os resultados encontrados indicam que a demanda por políticas, o comportamento dos diferentes níveis de governo e a existência de serviços similares ofertados por outras redes são fatores importantes que influenciam a provisão de políticas. Não há relação entre o partido do prefeito e a política de educação local, mas há relação entre a política local de educação e o partido do governador. Ainda assim, os resultados não indicam que esta relação seja constante ao longo do tempo.

Palavras-chave: Partidos políticos; prefeitos; governadores; política de educação; federalismo. 


\begin{abstract}
When we observe how political parties position themselves in the federal arena, we can see that they differ in their priorities established for public policy. However, we do not know if these priorities expressed by legislators in the federal arena, translate into policies when their parties are in control of the local executive power. Few studies have been devoted to the investigation of the influence of Brazilian political parties on the policies implemented by subnational governments. This work aim to give a contribution to this research agenda by i) the presentation of a formal model that simplifies and exposes the best options of mayors from different parties when there are party preferences on policy and when these preferences are absent; and ii) by the analysis of the education policy developed by the mayors and their parties. The results indicate that the policies demand, the behaviour of the different levels of government and the existence of similar services offered by other networks are important factors that influence the provision of policies. There is no relation between the mayor's party and the local education policy, but there is a relation between the local education policy and the governor's party. Still, the results do not indicate that this relation is constant over time.
\end{abstract}

Keywords: Political parties; mayors; governors; education policy; federalism. 


\section{Sumário}

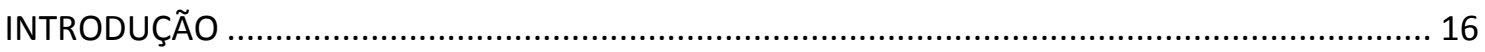

CAPÍTULO 1: GASTOS E ACESSO À EDUCAÇÃO NOS MUNICÍPIOS BRASILEIROS (2000 - 2012).. 19

1.1 A Educação Municipal e seu Contexto Institucional ........................................................... 20

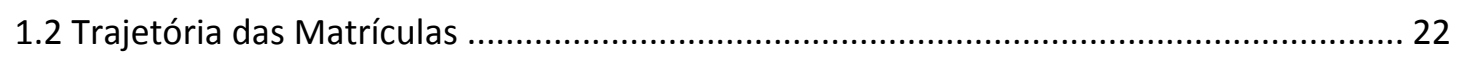

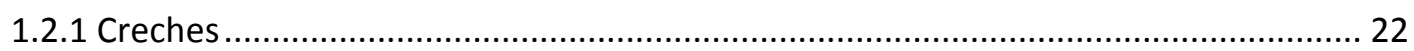

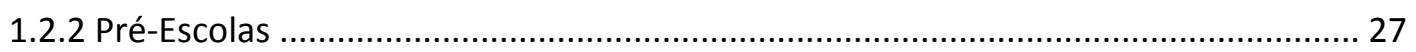

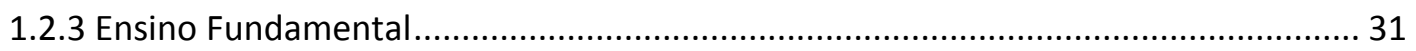

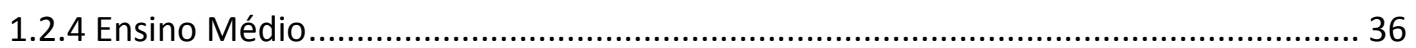

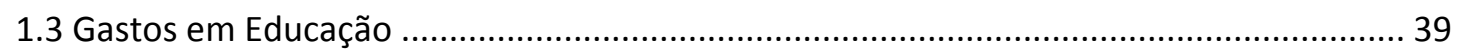

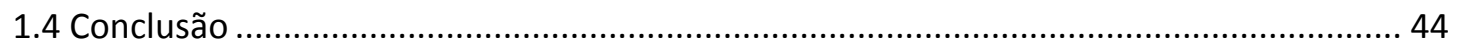

CAPÍTULO 2: PARTIDOS POLÍTICOS E POLÍTICAS PÚBLICAS - ABORDAGENS CLÁSSICAS E

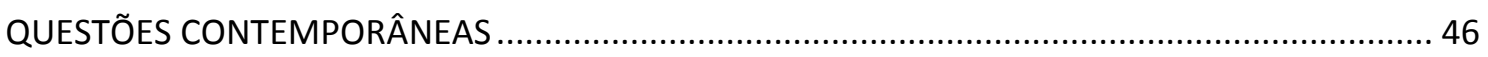

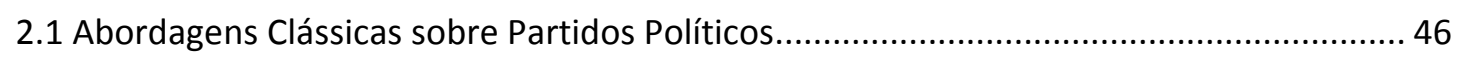

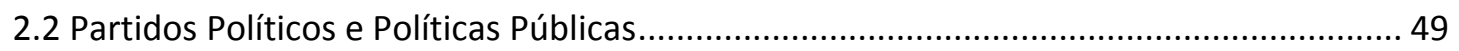

2.3 Política Partidária em Governos Subnacionais.................................................................. 52

2.4 A Questão da Interação na Agenda de Estudos Brasileira ................................................ 54

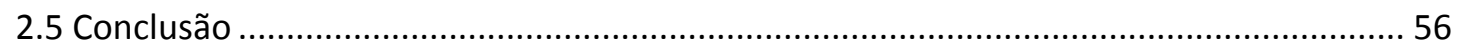

CAPÍTULO 3: UM MODELO FORMAL DE INFLUÊNCIA PARTIDÁRIA.............................................. 58

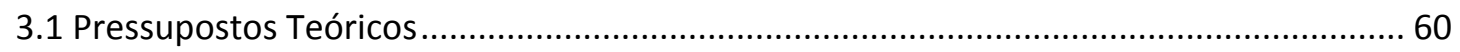

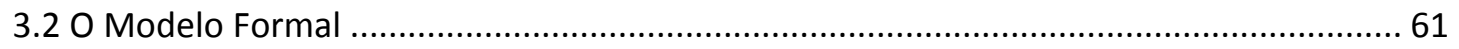

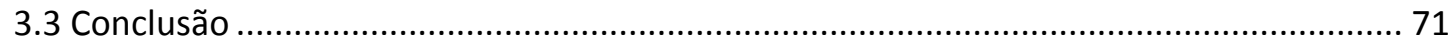

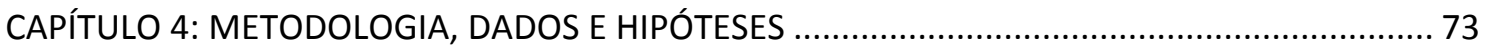

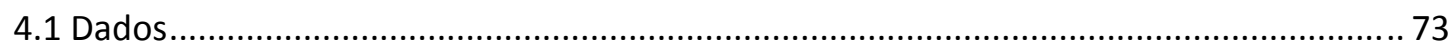

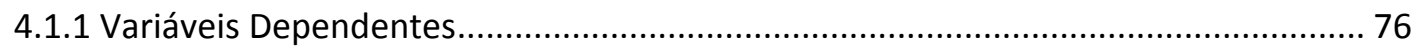

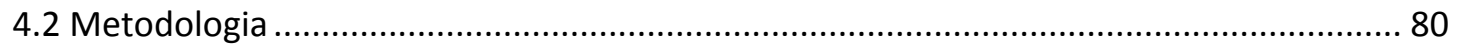

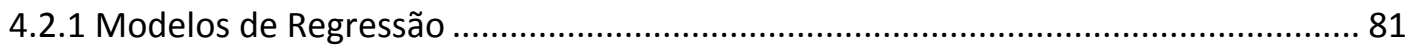

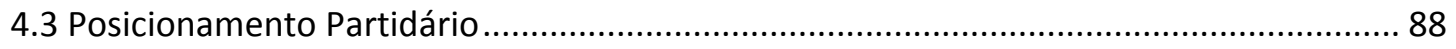

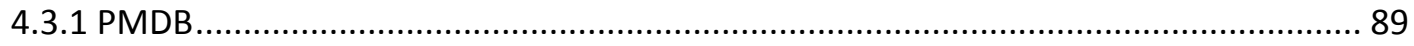

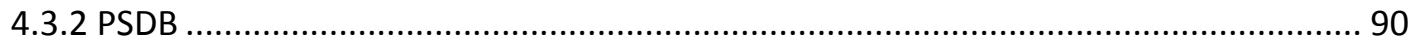

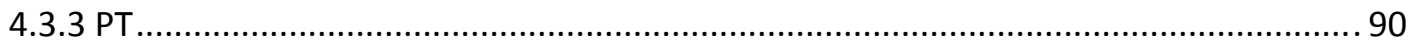

4.3.4 Influência do Partido dos Governadores................................................................. 91

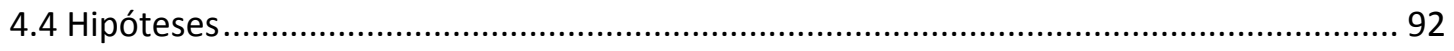

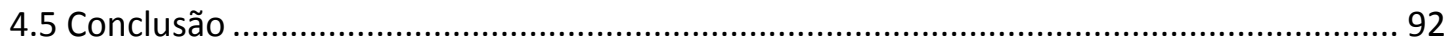


CAPÍTULO 5: GOVERNOS MUNICIPAIS E POLÍTICA PARTIDÁRIA - A POLÍTICA DE EDUCAÇÃO NOS

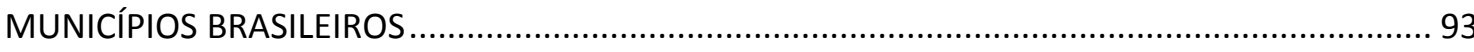

5.1 Criação de Vagas na Rede Municipal de Ensino ................................................................ 94

5.1.1 Criação de Vagas nas Creches Municipais................................................................ 94

5.1.2 Criação de Vagas nas Pré-Escolas Municipais .......................................................... 100

5.1.3 Criação de Vagas no Ensino Fundamental Municipal ................................................ 104

5.1.4 Partidos Políticos e Criação de Vagas nas Redes Municipais de Ensino .................. 109

5.2 Gastos na Rede Municipal de Ensino …….................................................................... 113

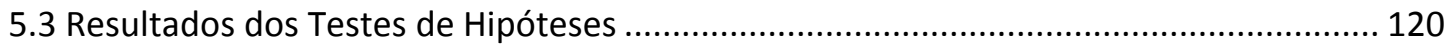

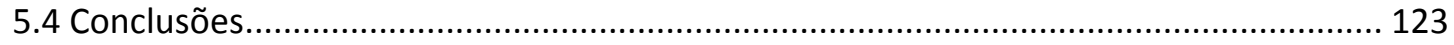

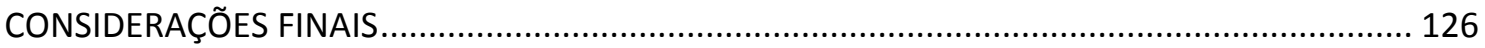

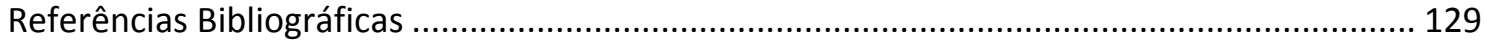

APÊNDICE A: ESTATÍSTICAS DESCRITIVAS DAS VARIÁVEIS UTILIZADAS NOS MODELOS DE

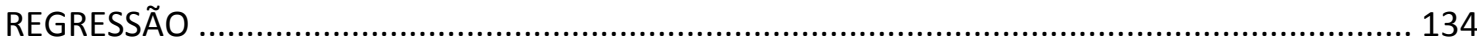

APÊNDICE B: MATRIZES DE CORRELAÇÃO DAS VARIÁVEIS UTILIZADAS NOS MODELOS DE

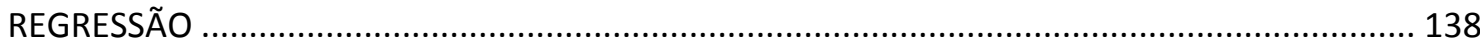

APÊNDICE C: GRÁFICOS DE EFEITO MARGINAL DA DEMANDA SOBRE A CRIAÇÃO DE VAGAS EM CRECHES, PRÉ-ESCOLAS E ENSINO FUNDAMENTAL NO GOVERNO DOS PREFEITOS DOS PARTIDOS DESTACADOS.

APÊNDICE D: GRÁFICOS DE EFEITO MARGINAL DOS PARTIDOS DOS PREFEITOS SOBRE A CRIAÇÃO DE VAGAS EM CRECHES, PRÉ-ESCOLAS E ENSINO FUNDAMENTAL QUANDO A DEMANDA POR VAGAS VARIA

APÊNDICE E: ESTADOS GOVERNADOS PELO PMDB, PSDB E PT (1999-2014) 


\section{LISTA DE FIGURAS}

Figura 3.1: Partido P Assume o Governo após Saída do Partido O.................................................. 64

Figura 3.2: Posicionamento Relativo do Partido $O$ e do Partido P no Cenário 1 e no Cenário 265

Figura 3.3: Partido O Assume o Governo após Saída do Partido P ............................................. 65

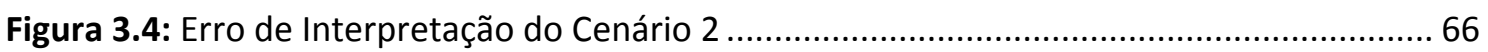

Figura 3.5: Partido O Assume seu Segundo Mandato Consecutivo...............................................6 66

Figura 3.6: Competição Política e Convergência entre Dois Partidos O ...................................... 67

Figura 3.7: Partido P Assume seu Segundo Mandato Consecutivo ..............................................6 67

Figura 3.8: Partido $P$ Assume o Governo após Saída de Partido $P$ com Preferências Opostas às

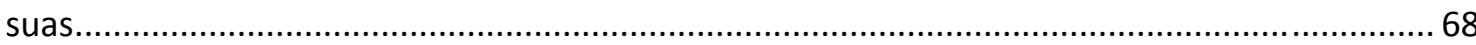

Figura 3.9: Cenário Procurado pela Mainstream dos Estudos sobre Influência Partidária ......... 68

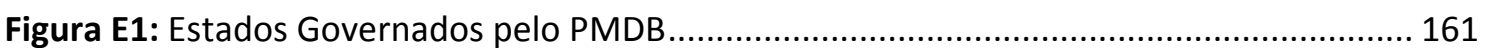

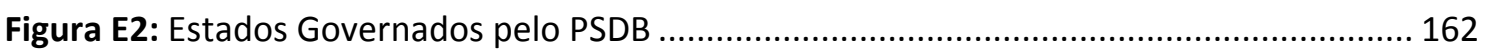

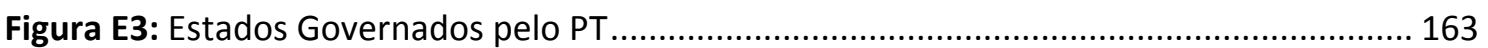




\section{LISTA DE TABELAS}

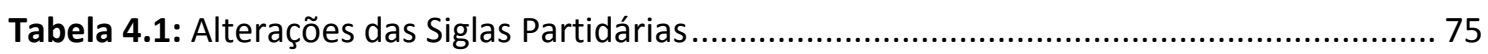

Tabela 4.2: Estatísticas Descritivas das Vagas Criadas na Rede Municipal de Ensino ................. 76

Tabela 4.3: Critérios para a Identificação e Exclusão de Casos Inconsistentes ............................ 78

Tabela 4.4: Estatísticas Descritivas da Variação nos Gastos em Educação e em suas Subfunções na Rede Municipal de Ensino

Tabela 4.5: Variáveis Incluídas nos Modelos para a Estimação da Criação de Vagas na Rede Municipal de Ensino

Tabela 4.6: Variáveis Incluídas nos Modelos para a Estimação da Variação nos Gastos da Rede Municipal de Ensino em Educação e suas Subfunções

Tabela 5.1: Modelos de Regressão para a Criação de Vagas em Creches Municipais (2000 2004)

Tabela 5.2: Modelos de Regressão para a Criação de Vagas em Creches Municipais (2004 2008)

Tabela 5.3: Modelos de Regressão para a Criação de Vagas em Creches Municipais (2008 2012)

Tabela 5.4: Modelos de Regressão para a Criação de Vagas em Pré-Escolas Municipais (2000 2004)

Tabela 5.5: Modelos de Regressão para a Criação de Vagas em Pré-Escolas Municipais (2004 2008)

Tabela 5.6: Modelos de Regressão para a Criação de Vagas em Pré-Escolas Municipais (2008 -

Tabela 5.7: Modelos de Regressão para a Criação de Vagas no Ensino Fundamental Municipal (2000 - 2004)

Tabela 5.8: Modelos de Regressão para a Criação de Vagas no Ensino Fundamental Municipal (2004 - 2008) 106

Tabela 5.9: Modelos de Regressão para a Criação de Vagas no Ensino Fundamental Municipal (2008 - 2012)

Tabela 5.10: Modelos de Regressão para a Variação dos Gastos na Educação Municipal (2005 2008)

Tabela 5.11: Modelos de Regressão para a Variação dos Gastos na Educação Municipal (2009 2012)

Tabela 5.12: Modelos de Regressão para a Variação dos Gastos em Educação Infantil Municipal (2009 - 2012)

Tabela 5.13: Modelos de Regressão para a Variação dos Gastos em Ensino Fundamental Municipal (2009 - 2012)

Tabela A1: Estatísticas descritivas das variáveis utilizadas nos modelos de regressão 134 


\section{LISTA DE GRÁFICOS}

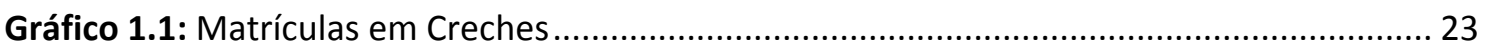

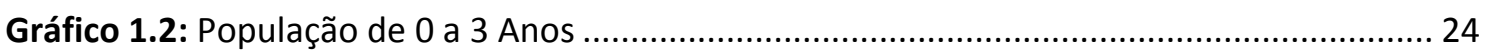

Gráfico 1.3: Demanda Atendida por Vagas em Creches ............................................................. 24

Gráfico 1.4: Matrículas em Creches por Rede de Ensino........................................................... 26

Gráfico 1.5: Participação das Redes de Ensino no Total de Matrículas em Creches ................... 26

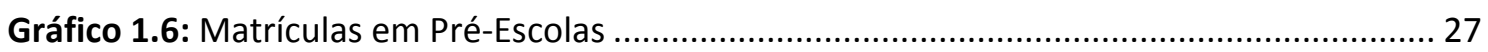

Gráfico 1.7: População em Idade Ideal para a Pré-Escola ............................................................. 28

Gráfico 1.8: Demanda Atendida por Vagas em Pré-Escolas ........................................................ 28

Gráfico 1.9: Matrículas em Pré-Escolas por Rede de Ensino ....................................................... 30

Gráfico 1.10: Participação das Redes de Ensino no Total de Matrículas em Pré-Escolas............ 31

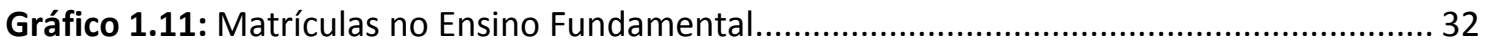

Gráfico 1.12: Matrículas no Ensino Fundamental de 8 e 9 Anos ................................................. 33

Gráfico 1.13: População em Idade Ideal para o Ensino Fundamental....................................... 33

Gráfico 1.14: Demanda Atendida por Vagas no Ensino Fundamental ...................................... 34

Gráfico 1.15: Matrículas no Ensino Fundamental por Rede de Ensino .................................... 35

Gráfico 1.16: Participação das Redes de Ensino no Total de Matrículas no Ensino Fundamental .35

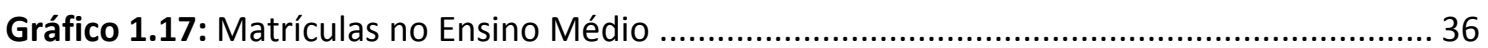

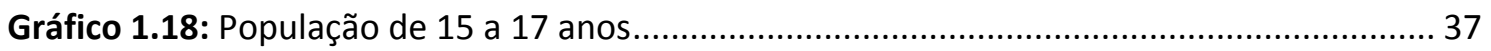

Gráfico 1.19: Demanda Atendida por Vagas no Ensino Médio ................................................. 37

Gráfico 1.20: Matrículas no Ensino Médio por Rede de Ensino .................................................. 38

Gráfico 1.21: Participação das Redes de Ensino no Total de Matrículas no Ensino Médio......... 39

Gráfico 1.22: Valor Mínimo de Gasto por Aluno/Ano Estabelecido pelo Governo Federal ....... 41

Gráfico 1.23: Percentual da Receita Orçamentária Destinado à Educação nos Municípios com até 50 Mil Moradores.

Gráfico 1.24: Percentual dos Gastos em Educação Destinado ao Ensino Fundamental nos Municípios com até 50 Mil Moradores

Gráfico 1.25: Percentual dos Gastos em Educação Destinado à Educação Infantil nos Municípios com até 50 Mil Moradores.

Gráfico 5.1: Partidos dos prefeitos e criação de vagas em creches municipais (2000 - 2004)...110

Gráfico 5.2: Partidos dos prefeitos e criação de vagas em creches municipais (2004 - 2008)... 110

Gráfico 5.3: Partidos dos prefeitos e criação de vagas em creches municipais (2008 - 2012)... 110

Gráfico 5.4: Partidos dos prefeitos e criação de vagas em pré escolas municipais (2000 - 2004)

Gráfico 5.5: Partidos dos prefeitos e criação de vagas em pré escolas municipais (2004 - 2008) 
Gráfico 5.6: Partidos dos prefeitos e criação de vagas em pré escolas municipais (2008 - 2012)

Gráfico 5.7: Partidos dos prefeitos e criação de vagas no ensino fundamental municipal (2000 2004)

Gráfico 5.8: Partidos dos prefeitos e criação de vagas no ensino fundamental municipal (2004 2008)

Gráfico 5.9: Partidos dos prefeitos e criação de vagas no ensino fundamental municipal (2008 2012)

Gráfico 5.10: Partidos dos governadores e criação de vagas em creches municipais (2000 - 2004)

Gráfico 5.11: Partidos dos governadores e criação de vagas em creches municipais (2004 - 2008)

Gráfico 5.12: Partidos dos governadores e criação de vagas em creches municipais (2008 - 2012)

Gráfico 5.13: Partidos dos governadores e criação de vagas em pré escolas municipais (2000 2004)

Gráfico 5.14: Partidos dos governadores e criação de vagas em pré escolas municipais (2004 2008)

Gráfico 5.15: Partidos dos governadores e criação de vagas em pré escolas municipais (2008 2012)

Gráfico 5.16: Partidos dos governadores e criação de vagas no ensino fundamental municipal (2000 - 2004)

Gráfico 5.17: Partidos dos governadores e criação de vagas no ensino fundamental municipal (2004 - 2008)

Gráfico 5.18: Partidos dos governadores e criação de vagas no ensino fundamental municipal (2008 - 2012)

Gráfico 5.19: Partidos dos prefeitos e variação dos gastos (\%) em educação municipal (2005 2008)

Gráfico 5.20: Partidos dos prefeitos e variação dos gastos (\%) em educação municipal (2009 2012)

Gráfico 5.21: Partidos dos prefeitos e variação dos gastos (\%) em educação Infantil municipal (2009 - 2012)

Gráfico 5.22: Partidos dos prefeitos e variação dos gastos (\%) em ensino fundamental municipal (2009 - 2012)

Gráfico 5.23: Partidos dos governadores e variação dos gastos (\%) em educação municipal (2005 - 2008)

Gráfico 5.24: Partidos dos governadores e variação dos gastos (\%) em educação municipal (2009 - 2012)

Gráfico 5.25: Partidos dos governadores e variação dos gastos (\%) em educação infantil municipal (2009 - 2012) 
Gráfico 5.26: Partidos dos governadores e variação dos gastos (\%) em ensino fundamental municipal (2009 - 2012) 119

Gráfico C1: Efeito marginal da demanda sobre a criação de vagas em creches no governo dos prefeitos dos partidos destacados (2000-2004)

Gráfico C2: Efeito marginal da demanda sobre a criação de vagas em creches no governo dos prefeitos dos partidos destacados (2004-2008)

Gráfico C3: Efeito marginal da demanda sobre a criação de vagas em creches no governo dos prefeitos dos partidos destacados (2008-2012) 151

Gráfico C4: Efeito marginal da demanda sobre a criação de vagas em pré escolas no governo dos prefeitos dos partidos destacados (2000-2004) 151

Gráfico C5: Efeito marginal da demanda sobre a criação de vagas em pré escolas no governo dos prefeitos dos partidos destacados (2004-2008) 151

Gráfico C6: Efeito marginal da demanda sobre a criação de vagas em pré escolas no governo dos prefeitos dos partidos destacados (2008-2012) 151

Gráfico C7: Efeito marginal da demanda sobre a criação de vagas em ensino fundamental no governo dos prefeitos dos partidos destacados (2000-2004) 151

Gráfico C8: Efeito marginal da demanda sobre a criação de vagas em ensino fundamental no governo dos prefeitos dos partidos destacados (2004-2008) 151

Gráfico C9: Efeito marginal da demanda sobre a criação de vagas em ensino fundamental no governo dos prefeitos dos partidos destacados (2008-2012) 151

Gráfico D1: Efeito marginal dos partidos dos prefeitos sobre a criação de vagas em creches quando a demanda por vagas varia (2000 - 2004)

Gráfico D2: Efeito marginal dos partidos dos prefeitos sobre a criação de vagas em creches quando a demanda por vagas varia (2004 - 2008) 153

Gráfico D3: Efeito marginal dos partidos dos prefeitos sobre a criação de vagas em creches quando a demanda por vagas varia (2008 - 2012) 154

Gráfico D4: Efeito marginal dos partidos dos prefeitos sobre a criação de vagas em pré escolas quando a demanda por vagas varia (2000 - 2004)

Gráfico D5: Efeito marginal dos partidos dos prefeitos sobre a criação de vagas em pré escolas quando a demanda por vagas varia (2004 - 2008) 156

Gráfico D6: Efeito marginal dos partidos dos prefeitos sobre a criação de vagas em pré escolas quando a demanda por vagas varia (2008 - 2012)

Gráfico D7: Efeito marginal dos partidos dos prefeitos sobre a criação de vagas no ensino fundamental quando a demanda por vagas varia (2000 - 2004) 158

Gráfico D8: Efeito marginal dos partidos dos prefeitos sobre a criação de vagas no ensino fundamental quando a demanda por vagas varia (2004 - 2008) 159

Gráfico D9: Efeito marginal dos partidos dos prefeitos sobre a criação de vagas no ensino fundamental quando a demanda por vagas varia (2008 - 2012) 160 


\title{
INTRODUÇÃO
}

\begin{abstract}
"Quanto mais a humanidade for consciente das vantagens que uma democracia, mesmo imperfeita, apresenta em relação a uma aristocracia, mesmo que esta funcione relativamente bem, menos provável será que o reconhecimento dos defeitos da democracia provoque um retorno à aristocracia"
\end{abstract}

(Robert Michels)

Atores centrais dos governos democráticos, os partidos políticos ainda estão para receber a atenção que merecem em estudos sobre os governos subnacionais no Brasil. A relevância desta agenda é conjunta à necessidade de entender como nosso sistema partidário funciona para além da arena federal. Se os estudos sobre o comportamento dos partidos políticos na arena federal são abundantes, a atuação dos partidos políticos na implementação de políticas ainda é muito pouco estudada.

Consoante com esta interpretação, este trabalho pretende entender como partidos políticos interagem nos governos subnacionais de uma federação com grau razoavelmente elevado de centralização da autoridade sobre políticas e quais são os resultados observáveis destas interações sobre a implementação de políticas públicas. Neste caso, este trabalho examina o comportamento dos partidos tendo em vista as políticas que são implementadas.

Estudar a importância dos partidos sobre todas as políticas implementadas pelos governos subnacionais seria tarefa impossível. Por isto, optei por limitar a dimensão empírica deste trabalho a apenas uma política social: a política de educação.

A escolha por uma política social se deve ao objetivo de entender o comportamento dos partidos políticos em políticas nas quais seu discurso comum não aponta clivagens e oposições claras. A educação apresenta esta característica, pois não há partido que afirme que educação não será prioridade de seu governo. Esta também é uma área em que o governo federal exerce forte influência sobre as políticas implementadas pelos governos subnacionais. Assim, a política de educação permite observar se os partidos políticos se diferenciam em contextos em que os governos subnacionais desempenham 
papel importante na implementação ao mesmo tempo que os partidos não apresentam um discurso antagônico.

Como é mostrado no capítulo 1 desta dissertação, o exame da implementação da política de educação indica que deve ser dada atenção ao papel dos municípios. A maior parte do ensino em creches, pré escolas e ensino fundamental é gerida pelas redes municipais de ensino, nos municípios com até 50 mil habitantes. A política municipal de educação será mensurada de duas formas: i) o acesso ao ensino (a criação de vagas nos diferentes níveis de ensino); e ii) a variação dos gastos em educação, em educação infantil e em ensino fundamental.

Este trabalho se divide em cinco capítulos, além desta introdução e das considerações finais. O primeiro capítulo analisa o acesso e os gastos em educação nas diferentes redes e nos diferentes níveis de ensino de 2000 a 2012. Neste capítulo, também se discute o papel central que o governo federal desempenha na política educacional dos governos subnacionais. A análise se concentra sobre o ensino infantil e o ensino fundamental nos governos municipais.

O segundo capítulo faz um balanço da literatura sobre partidos políticos com a qual este trabalho dialoga. Parte-se de visões clássicas para estabelecer um diálogo entre tais visões e as proposições da agenda de pesquisa que estuda a influência dos partidos políticos sobre políticas públicas.

No capítulo 3, é desenvolvido um modelo formal que busca explicitar os fatores que afetam a relação entre os programas dos partidos políticos e as políticas públicas que estes implementam quando estão à frente de governos subnacionais. Este modelo pretende ser aplicável na análise da influência de partidos políticos sobre qualquer tipo de política, indo além da aplicação imediata deste trabalho na área da educação.

O capítulo 4 apresenta os dados utilizados nesta pesquisa, a metodologia empregada, as hipóteses de trabalho testadas e observações sobre as preferências do PMDB, PSDB e PT em relação à política de educação.

O capítulo 5 apresenta resultados dos modelos de regressão. Neste é discutida a compatibilidade do modelo apresentado no capítulo 3 para a análise das políticas de educação nos governos locais, ao mesmo tempo em que são apresentadas as relações 
entre as variações ocorridas na política de educação dos municípios e os partidos dos prefeitos. Por fim, são retomadas as hipóteses do capítulo 4 e são apresentados os resultados encontrados.

As considerações finais apresentam as principais contribuições deste trabalho e indicam questões importantes para estudos futuros sobre a influência dos partidos políticos sobre políticas públicas.

Este trabalho concluiu que a principal motivação dos prefeitos para expandir suas redes de ensino é atender a demanda por serviços educacionais em seus respectivos municípios, independentemente de sua filiação partidária. Entretanto, a decisão pela expansão de vagas leva em consideração a oferta de vagas por parte do governo estadual e da rede privada de ensino. Assim, as decisões dos demais provedores exercem influência importante sobre as políticas implementadas pelos prefeitos. Os incentivos federais também exercem influência sobre as decisões dos prefeitos, independentemente de sua filiação partidária. O Fundo de Manutenção e Desenvolvimento do Ensino Fundamental e de Valorização do Magistério (FUNDEF) teve maior impacto sobre a política local de educação que o Fundo de Manutenção e Desenvolvimento da Educação Básica e de Valorização dos Profissionais da Educação (FUNDEB) e isto ocorreu provavelmente porque quando o segundo entrou em vigência os orçamentos municipais estavam mais comprometidos do que quando o primeiro foi implementado. Por fim, os partidos dos governadores exercem influência sobre a políticas adotadas pelos prefeitos de seus respectivos municípios, mas esta relação não é constante ao longo do tempo, sendo orientada por fatores para além daqueles analisados neste trabalho. 


\title{
CAPÍTULO 1: GASTOS E ACESSO À EDUCAÇÃO NOS MUNICÍPIOS BRASILEIROS (2000 -
} 2012)

\begin{abstract}
"Não se deve alimentar a ilusão de que as normas legais 'resolvem', por si mesmas, os dilemas sociais. Mas os Pioneiros estavam certos: elas criam deveres mínimos (do poder público [...]), estimulam a distribuição crescente das oportunidades educacionais e abrem aos trabalhadores canais de acesso a todos os níveis de ensino"
\end{abstract}

(Florestan Fernandes)

Os prefeitos são atores chave na condução da política local de educação. O prefeito escolhe o secretário de educação de seu município; tem poder para influenciar o funcionamento do Conselho Municipal de Educação (CME), do Conselho de Acompanhamento e Controle Social do FUNDEF/FUNDEB (CACS) e dos demais órgãos instituídos localmente para gerir a educação municipal. O prefeito também pode determinar a construção de estabelecimentos de ensino e iniciar a legislação que determina os gastos em educação, incluindo aqueles destinados aos salários dos professores. Assim, os prefeitos são atores centrais da política local de educação nos municípios brasileiros. Resta saber se a agenda que eles adotam tem algum viés capaz de tornar previsível a implementação de determinadas políticas. Tendo em mente que o comportamento dos partidos políticos brasileiros é tema constante de diversos estudos, é de grande interesse saber se os partidos políticos afetam o comportamento dos prefeitos, influenciando na implementação de políticas no nível local.

Antes de discutir o papel dos partidos políticos na arena local, é preciso contextualizar melhor a política de educação nos municípios brasileiros. Este é o objetivo deste capítulo, que se divide em três seções. Na primeira seção, é apresentada breve discussão das relações entre a federação brasileira e a política de educação municipal. Na segunda seção, discorre-se sobre o comportamento das matrículas nos diferentes níveis de ensino e o papel da rede municipal em comparação com as redes estadual, federal e particular. Na terceira seção, é dada atenção aos gastos em educação nos municípios e à influência da legislação federal. Ao final, conclui-se que para compreender adequadamente a política de educação nos municípios é preciso levar em consideração 
o papel das diferentes redes de ensino, a influência da legislação federal, a interação com outros níveis de governo e da demanda local por políticas de educação.

\subsection{A Educação Municipal e seu Contexto Institucional}

A constituição de 1988, ao reconhecer os municípios como entes da federação brasileira, fez com que o número de sistemas de ensino existentes no país, que antes equivalia a um sistema para cada estado, crescesse ao ponto de termos um sistema de ensino para cada município mais os antigos sistemas estaduais que já existiam (DUARTE, 2005; RODRIGUEZ, 2001; SOUZA; FARIA, 2004). À fragmentação oriunda desta medida somouse outra medida centralizadora e limitadora da autonomia dos entes subnacionais: a obrigação constitucional de que os municípios e estados gastem em ensino $25 \%$ de suas receitas arrecadadas de impostos. Desta forma, enquanto houve multiplicação das instâncias responsáveis administrativamente por gerir a política de educação, houve manutenção da obrigação de direcionar gastos para a educação ${ }^{1}$.

O estabelecimento pela Constituição de competências concorrentes entre os entes federados em matéria de educação também deixa a relação aqui investigada mais complexa do que ela seria caso houvessem competências privativas. Como estados e municípios podem legislar sobre os mesmos temas, pode acontecer de eles se focarem em um mesmo público e competirem entre si para a oferta de um serviço, gerando baixa eficiência e desperdício de recursos públicos. Desta forma, para entender as políticas implementadas pelos prefeitos é preciso também saber em que contexto elas se inserem. Por isso, é necessário examinar a política implementada por outras redes de ensino, sejam políticas da rede estadual, federal ou privada.

Quando a atuação do governo federal é integrada à análise da política, é possível visualizar um quadro mais completo da influência que o sistema federativo brasileiro desempenha sobre a política local de educação. A participação do governo federal

\footnotetext{
${ }^{1}$ A Emenda Constitucional número 24 de 1983, mais conhecida como emenda Calmon, havia estabelecido que a União aplicaria em ensino, no mínimo, 13\% de suas receitas de imposto e que os estados municípios e o Distrito Federal aplicariam, no mínimo, $25 \%$ de suas receitas também em ensino. Esta obrigatoriedade vigorava no contexto de elaboração da Constituição de 1987 e certamente influenciou a decisão dos patamares mínimos de gasto então estabelecidos pela nova Constituição.
} 
cresceu significativamente em importância a partir do governo Fernando Henrique Cardoso (FHC), seja em termos específicos em relação à política de educação (PINTO, 2002) seja no que diz respeito ao conjunto das relações intergovernamentais (ARRETCHE, 2009; SÁTYRO, 2008). Em termos gerais, pode ser citada aqui a Lei de Responsabilidade Fiscal. Em termos mais específicos, podemos citar a Lei de Diretrizes e Bases da Educação Nacional (LDB), o FUNDEF e o Plano Nacional de Educação (PNE). A LDB e o FUNDEF influenciaram significativamente a política local de educação.

Entre os pontos mais destacados da LDB, está a definição de quais gastos seriam reconhecidos como gastos em Manutenção e Desenvolvimento do Ensino (MDE), medida realizada para impedir que governadores e prefeitos desviassem recursos da educação e os destinassem a outras áreas.

O FUNDEF se constituiu em um sistema de fundos estaduais que recolhia parte da receita arrecadada dos municípios e estados e a redistribuía de acordo com o número de matrículas que os governos subnacionais apresentaram no ano anterior. A emenda constitucional do FUNDEF foi parte de uma política do governo federal para estimular a expansão da oferta de matrículas no ensino fundamental visando sua universalização. Apesar de muito criticado, é possível dizer que o Fundo alcançou seu objetivo principal. Como consequência do FUNDEF (COSTA; DUARTE, 2008; PINTO, 2002) e da articulação entre governadores e prefeitos (GOMES, 2009), a rede municipal passou a ser a principal gestora do ensino fundamental na federação. No entanto, o FUNDEF, implementado a partir de 1998, possuía um prazo de duração limitado até 2006; a partir de 2007 o fundo foi substituído pelo FUNDEB (Fundo de Manutenção e Desenvolvimento da Educação Básica e de Valorização dos Profissionais da Educação), que manteve boa parte da lógica de funcionamento do fundo anterior, mas passou a realizar os repasses de receita de acordo com as matrículas realizadas em toda a educação básica de acordo com diferentes pesos atribuídos para matrículas em diferentes níveis e modalidades de ensino.

A expansão da abrangência do FUNDEB em relação ao seu antecessor pode ser explicada, em parte, pelas preferências do PT, que controlava a Presidência quando este foi apresentado e finalmente aprovado no último ano do primeiro mandato de Lula 
(2003 - 2006). O PT quando estava na oposição, durante o governo FHC, fez inúmeras críticas ao FUNDEF sendo uma das principais o fato de que, ao direcionar receitas apenas para o ensino fundamental, o fundo atrofiaria os demais níveis de ensino e acabaria trazendo mais prejuízo para a educação do que melhoras. Ainda assim, é preciso destacar que o projeto inicial do FUNDEB proposto pelo Executivo não contemplava o atendimento às creches (PINTO, 2007), algo não justificável de acordo com o posicionamento que o PT adotou durante todo o processo de votação do FUNDEF.

\subsection{Trajetória das Matrículas}

Para melhor entendimento da análise desenvolvida nos capítulos posteriores, é preciso levar em consideração os movimentos de expansão e de retração de matrículas no período analisado. Por isso, esta seção apresenta dados sobre o número total de matrículas por nível (creche, pré-escola, ensino fundamental e ensino médio) e por rede de ensino (municipal, estadual, federal e particular) em todos os municípios brasileiros com até 50 mil moradores.

O período examinado diz respeito aos anos 2000 a 2012. Para o período anterior à implementação do FUNDEF não dispomos de micro dados passíveis de desagregação por municípios em intervalos anuais. Por isso, a análise se restringe a um período de tempo tão restrito. Durante o desenvolvimento deste trabalho, foi observado que municípios grandes e pequenos não se comportam de forma similar em relação à gestão das suas matrículas. Assim, optou-se pela análise dos municípios com até 50 mil habitantes por eles representarem a maioria dos municípios brasileiros. Os dados apresentados neste capítulo também são auxiliares na exploração dos dados e na análise desenvolvida nos capítulos 4 e 5, respectivamente.

\subsubsection{Creches}

As creches no Brasil sempre apresentaram baixo atendimento de sua demanda potencial, com os mais baixos índices de atendimento de todos os níveis de ensino aqui analisados. Apesar de este nível de ensino apresentar significativo crescimento nos anos 
analisados, ele ainda é o nível de ensino que mais precisa melhorar no que diz respeito à inclusão. Os gráficos a seguir demonstram isso:

Gráfico 1.1: Matrículas em Creches

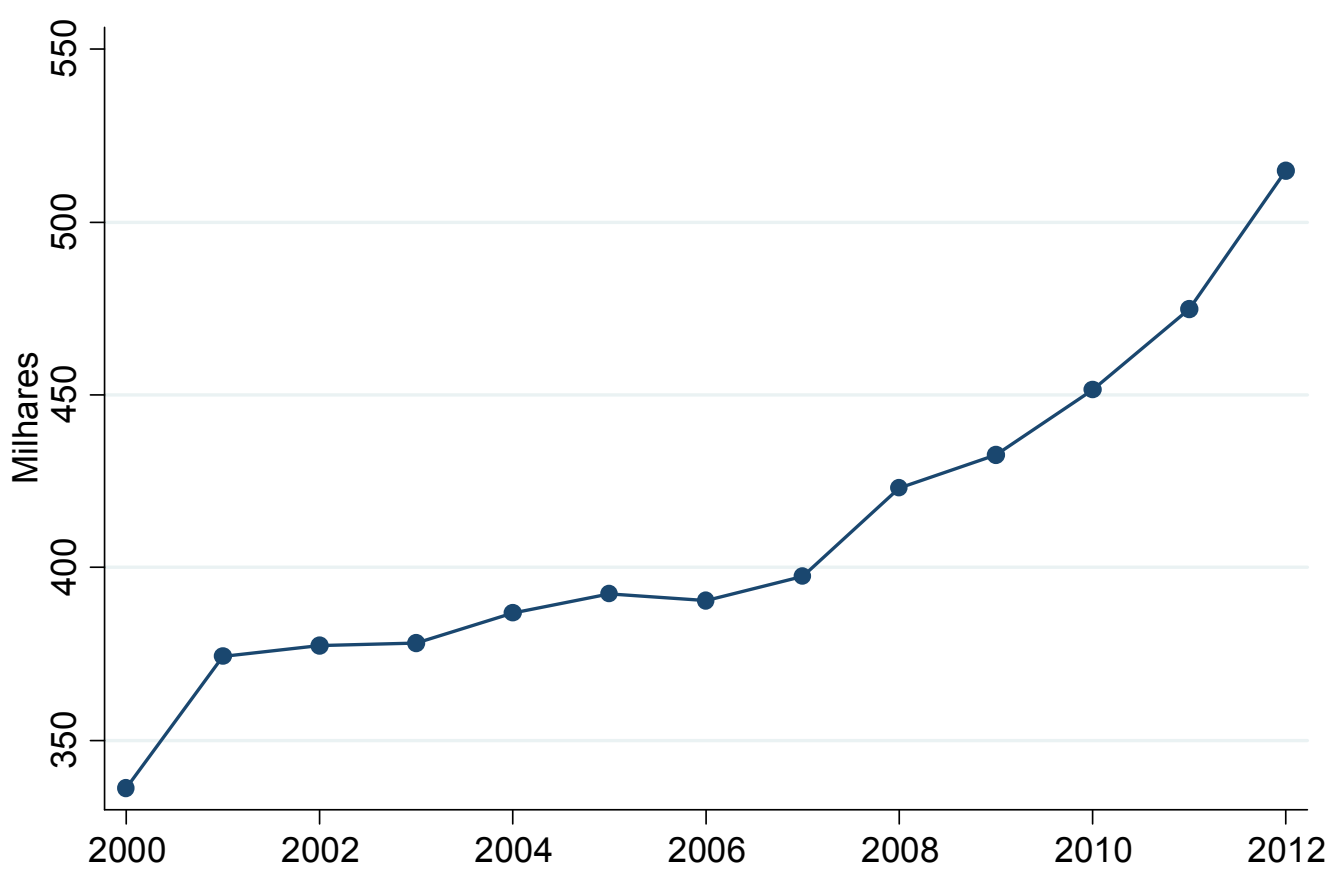

Fonte: Censo Escolar (2000 - 2012). 
Gráfico 1.2: População de 0 a 3 Anos

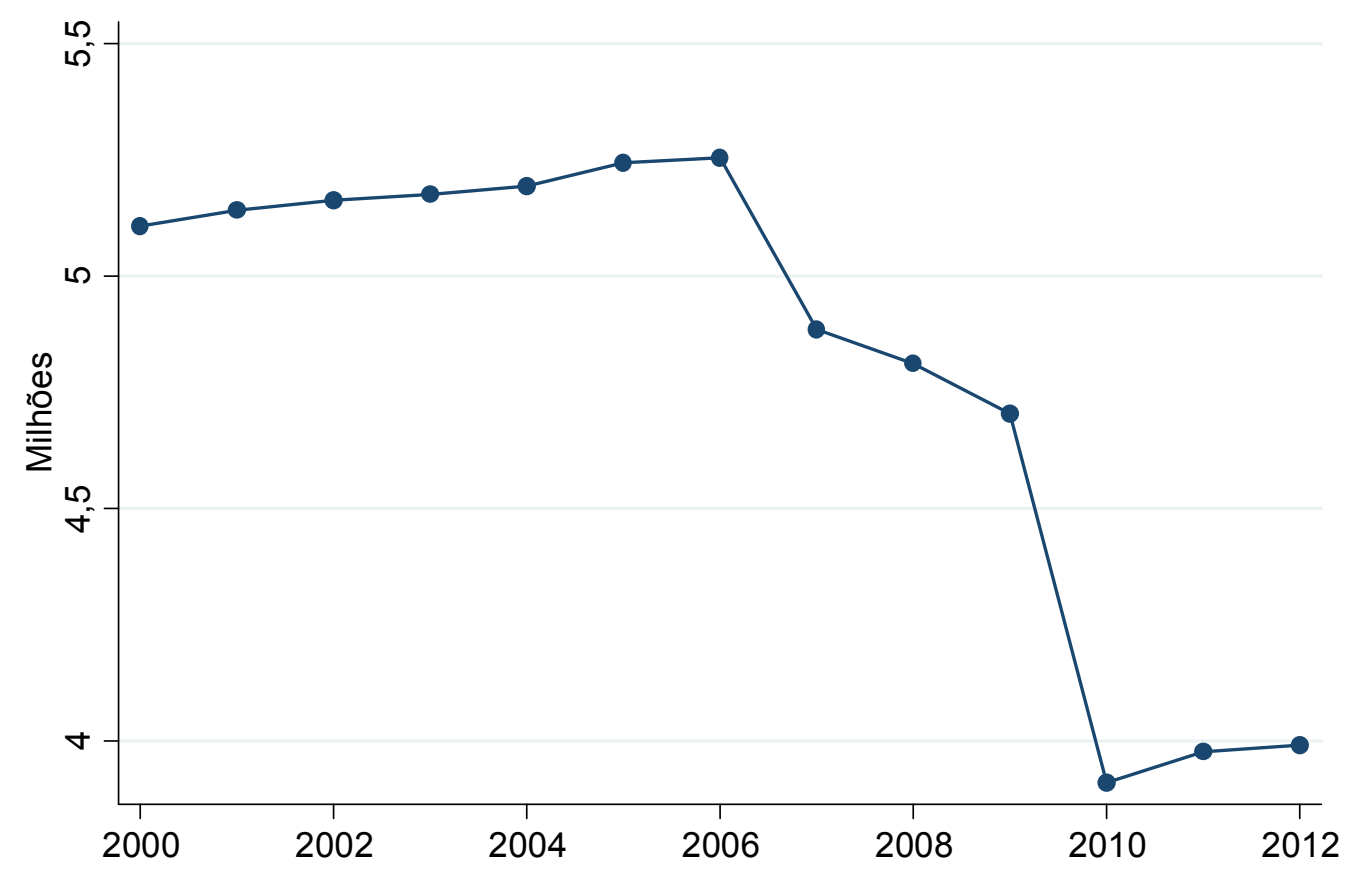

Fonte: Estimativas Populacionais do DATASUS (2000 - 2012).

Gráfico 1.3: Demanda Atendida por Vagas em Creches

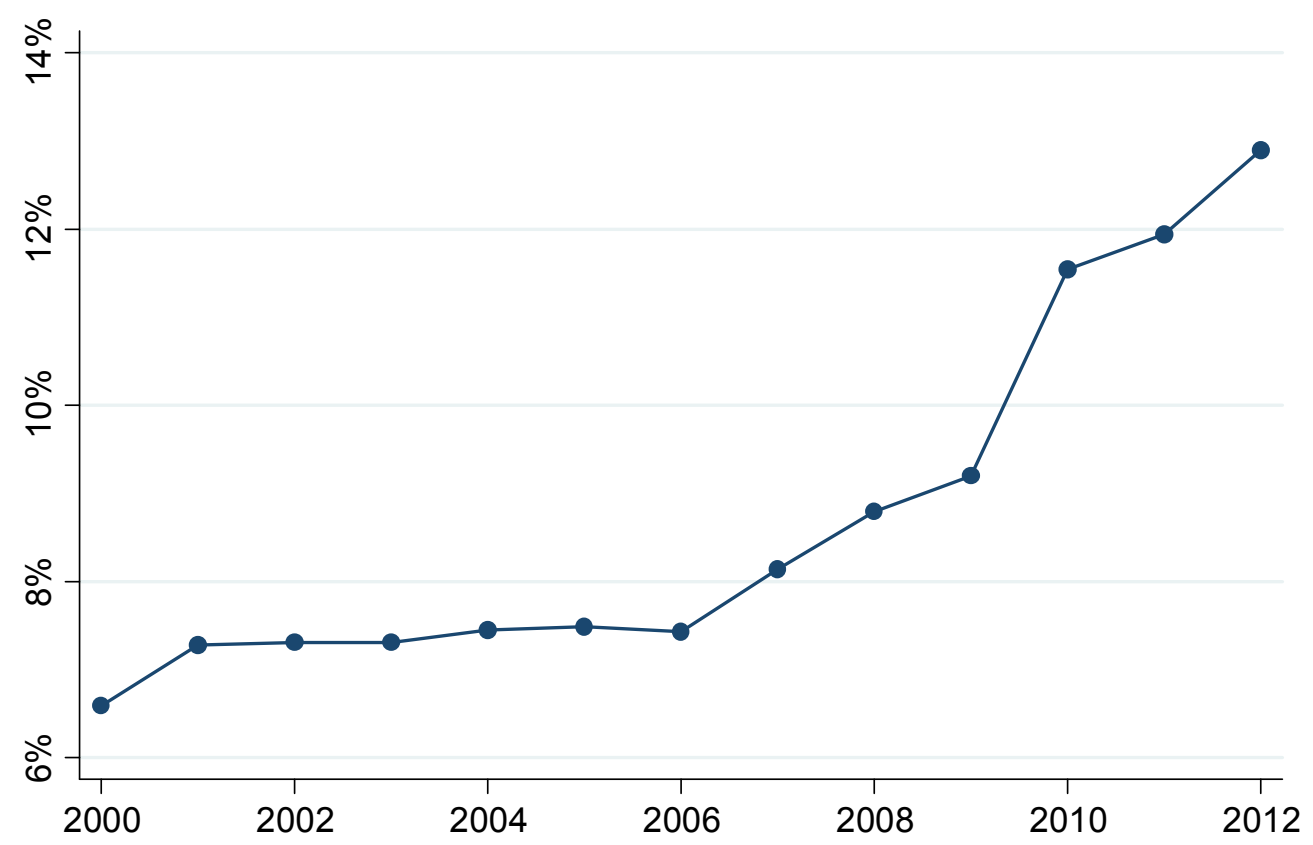

Fonte: Censo Escolar (2000 - 2012) e

Estimativas Populacionais do DATASUS (2000 - 2012). 
Como mostram os gráficos, houve considerável expansão das matrículas em creches no período analisado. Chama atenção o fato de que, apesar de o FUNDEF desestimular o investimento em creches devido à clara prioridade dada ao ensino fundamental (COSTA; DUARTE, 2008; OLIVEIRA, 2012), em seu período de vigência houve crescimento razoável do número de matrículas nas creches dos municípios de até 50 mil moradores. Mas certamente se destaca o período posterior à implementação do FUNDEB, ocorrendo significativa alteração para cima da inclinação da reta representante do número de matrículas.

Estes dados mostram que houve um crescimento das matrículas em creches e que o atendimento à demanda por vagas em creches $^{2}$ cresceu significativamente a partir de 2007. O gráfico da população na faixa etária ideal para ser atendida por creches deixa claro que em 2007 também houve grande queda da população de 0 a 3 anos no país, o que implicou que a expansão do número de matrículas em creche fosse combinada com a queda na demanda, fazendo com que ao final do período um percentual próximo a $13 \%$ da demanda do país por vagas em creches tivesse atendimento.

Os gráficos a seguir mostram os mesmos dados do gráfico 1, mas desagregados por rede de ensino:

\footnotetext{
${ }^{2}$ Para simplificar a análise, foi assumido que em nenhum nível de ensino há distorção idade-série e que a demanda por vagas em cada nível de ensino se limita à população em idade ideal para cursar cada um desses níveis. Apesar de esta premissa ser irreal, ela não prejudica o desenvolvimento do trabalho, pois é justificável acreditar que a distorção idade-série tem distribuição normal entre os municípios e que ela não apresenta relação com o partido no governo.
} 
Gráfico 1.4: Matrículas em Creches por Rede de Ensino

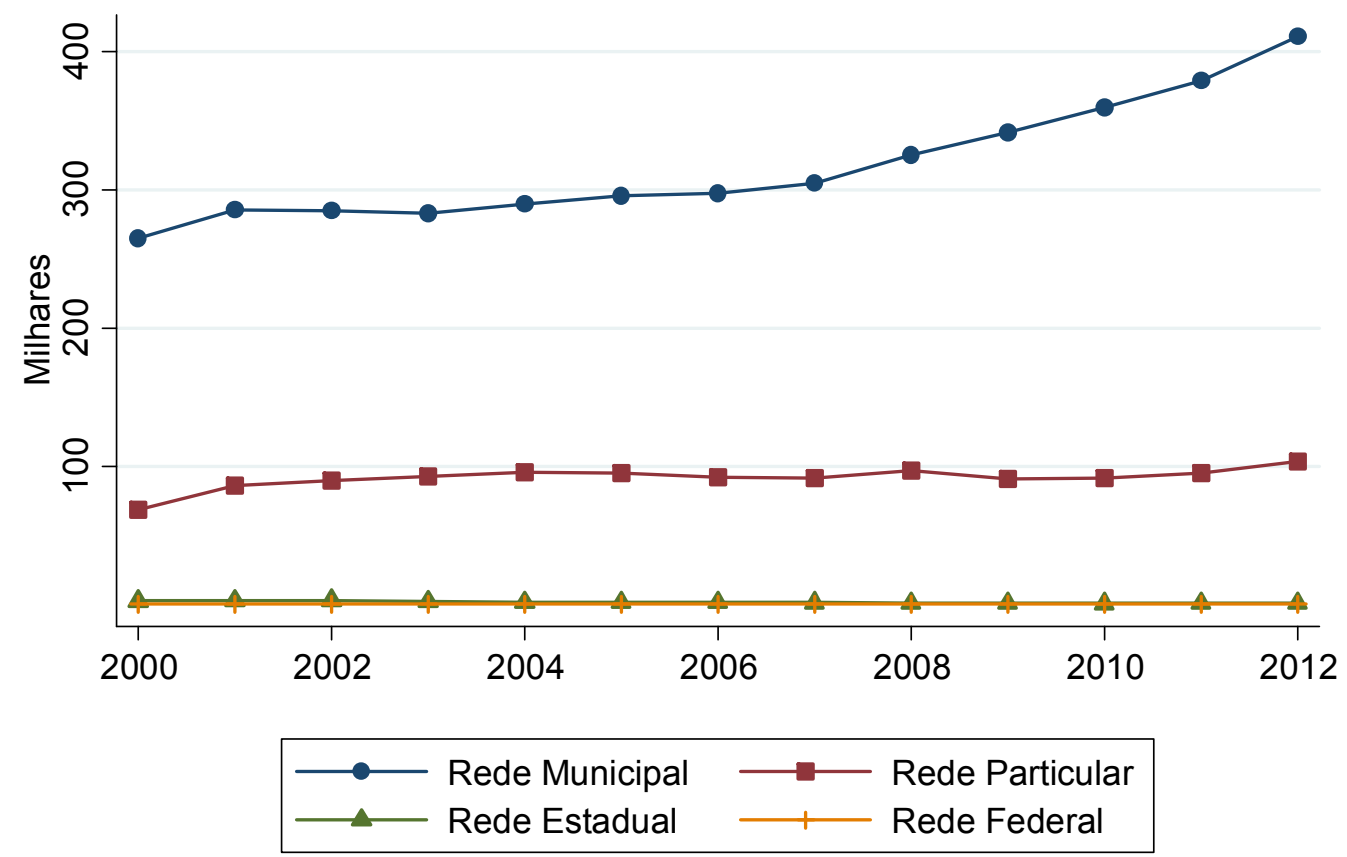

Fonte: Censo Escolar (2000 - 2012).

Gráfico 1.5: Participação das Redes de Ensino no Total de Matrículas em Creches

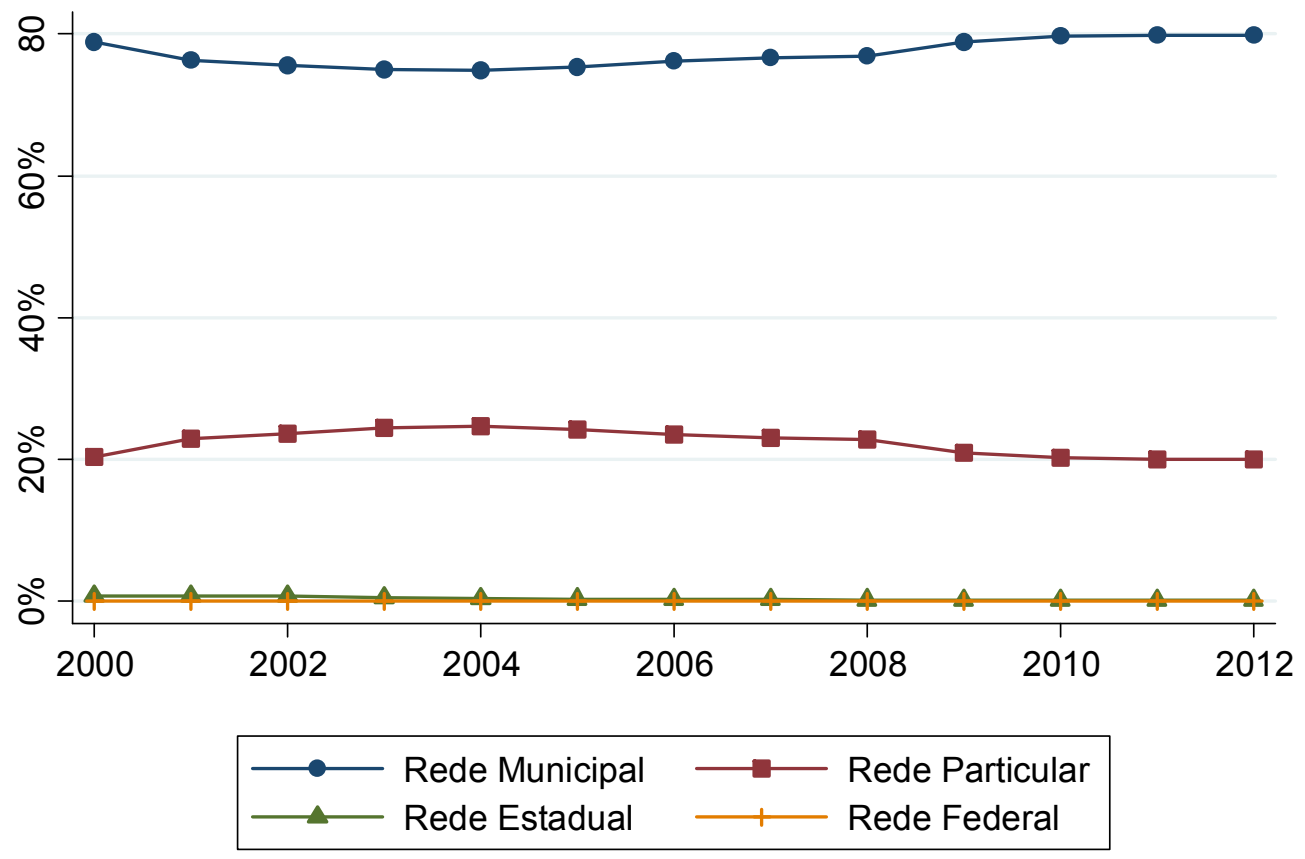

Fonte: Censo Escolar (2000 - 2012). 
Os gráficos evidenciam o papel central que a rede municipal e a rede particular têm na oferta de vagas em creches, uma vez que ambas as redes, juntas, respondem por quase $100 \%$ da oferta de matrículas em creches nos municípios de até 50 mil moradores. A partir da implementação do FUNDEB, houve clara expansão das redes municipais. Podemos, portanto, concluir que os municípios são atores centrais na expansão das matrículas em creches e que os estímulos federais certamente influenciaram na expansão deste nível de ensino.

\subsubsection{Pré-Escolas}

Apesar de as pré-escolas também integrarem a educação infantil, a evolução das matrículas neste nível de ensino apresenta comportamento diferente daquele visto nas creches. Contrariamente ao esperado, o número de matrículas na pré-escola apresenta crescimento durante o período de vigência do FUNDEF e queda durante o período de vigência do FUNDEB. Os gráficos para o período são exibidos abaixo:

Gráfico 1.6: Matrículas em Pré-Escolas

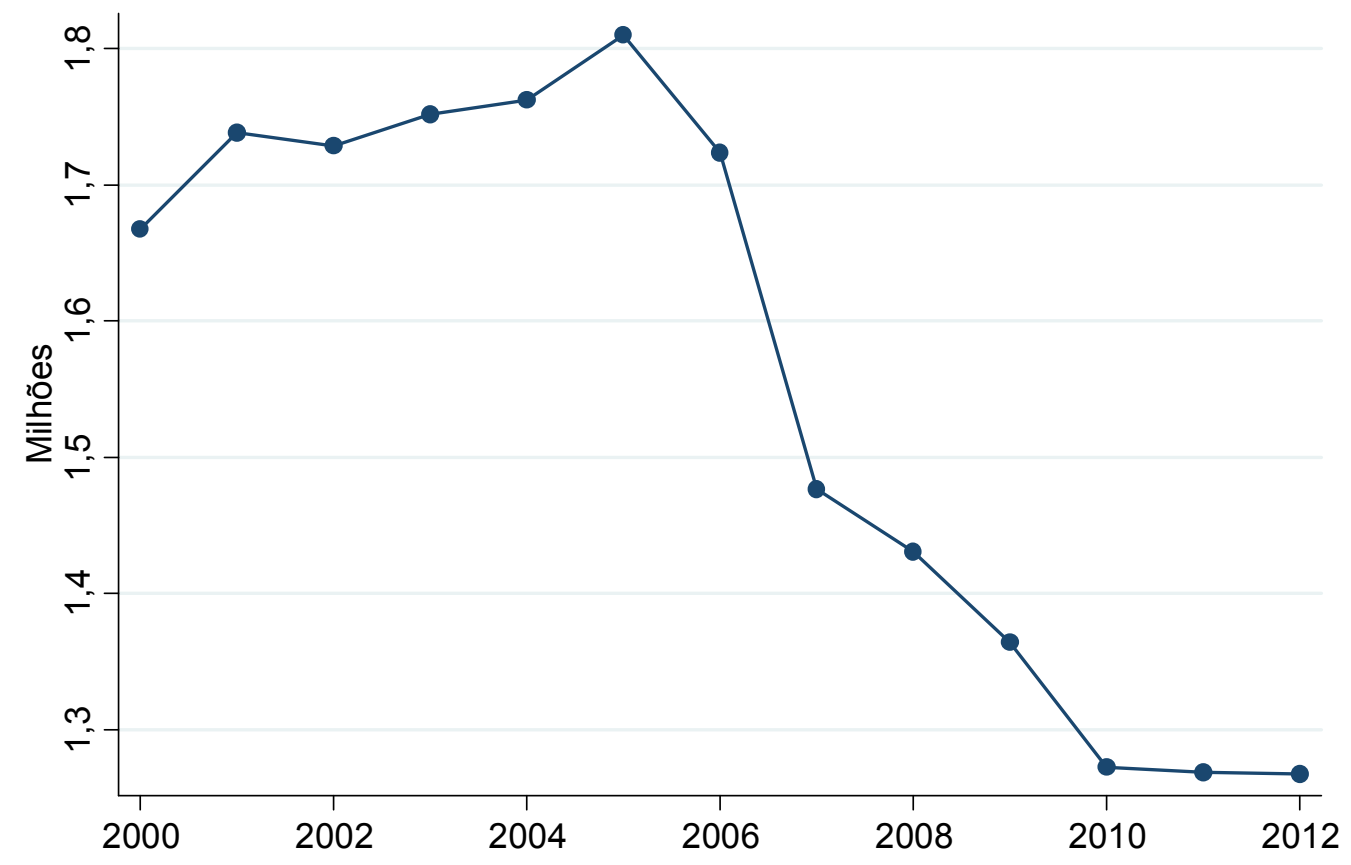

Fonte: Censo Escolar (2000 - 2012). 
Gráfico 1.7: População em Idade Ideal para a Pré-Escola

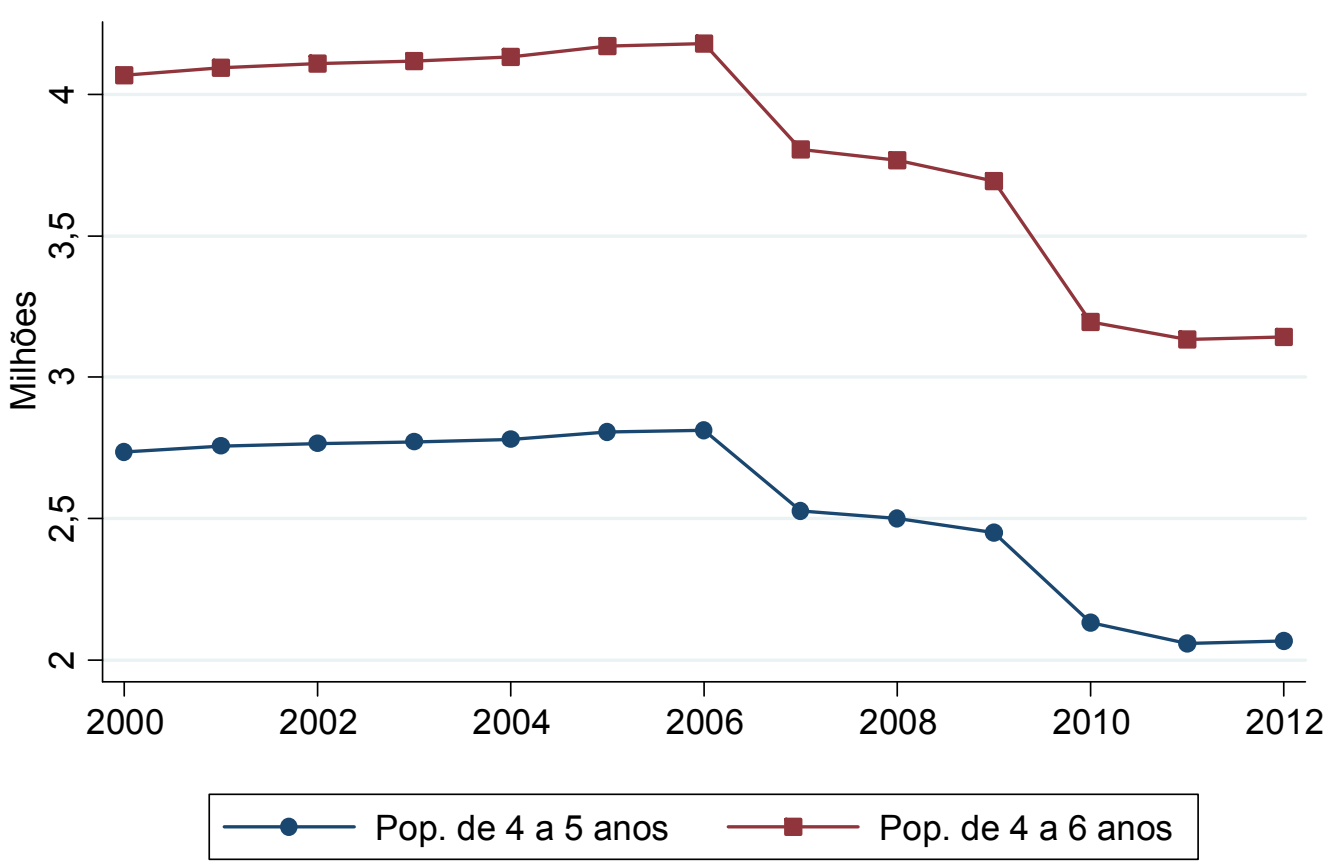

Fonte: Estimativas Populacionais do DATASUS (2000 - 2012).

Gráfico 1.8: Demanda Atendida por Vagas em Pré-Escolas

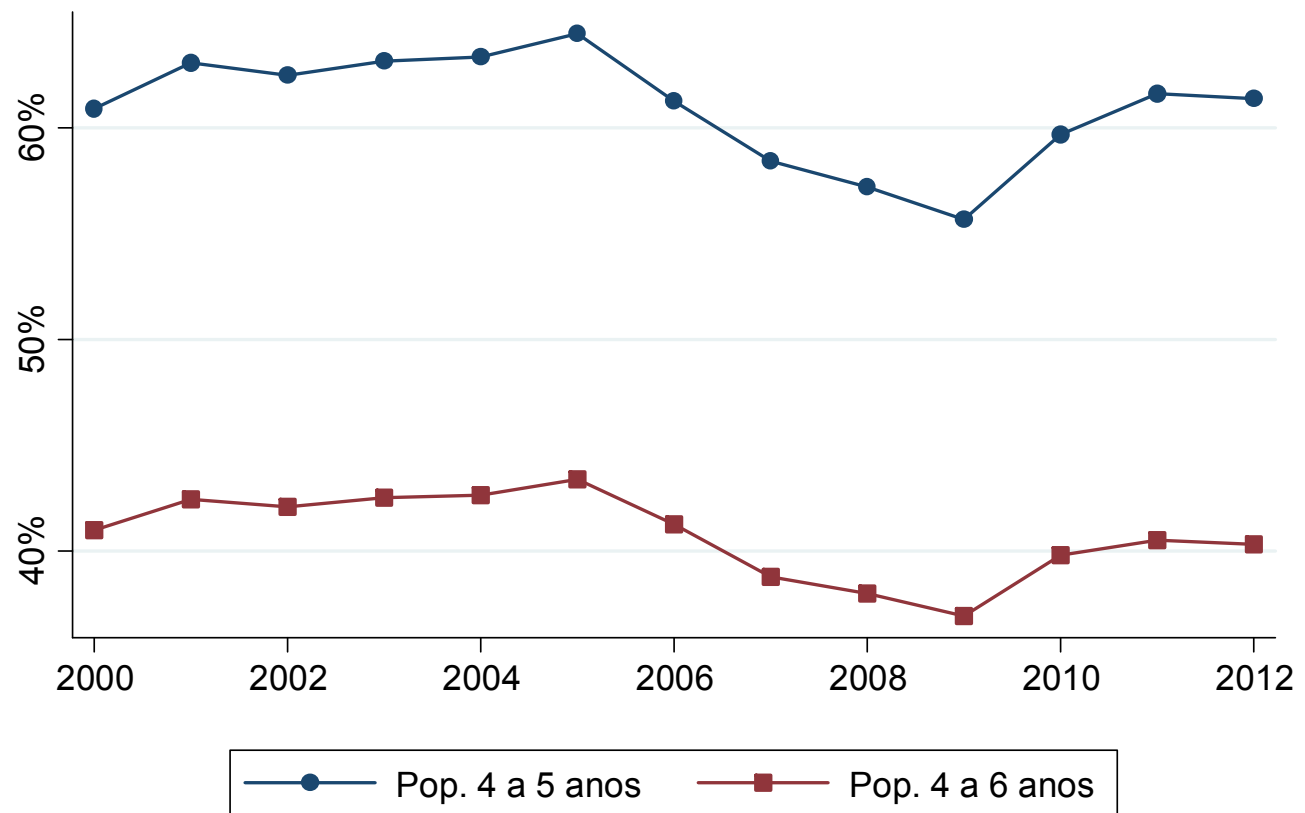

Fonte: Censo Escolar (2000 - 2012) e

Estimativas Populacionais do DATASUS (2000 - 2012). 
Em 2012, temos um número de matrículas na pré-escola inferior aos valores observados em 2000. Este comportamento das matrículas é afetado pela implementação do ensino fundamental de nove anos (Lei 11.274/06), que ocorreu com a incorporação de crianças de seis anos no ensino fundamental e fez com que o ensino pré-escolar, ao final do período analisado, fosse um ciclo de apenas dois anos, destinado a crianças de quatro e cinco anos apenas ${ }^{3}$. Assim, quando é observada a oferta de matrículas nas pré-escolas no período destacado, é necessário considerar que esta oferta também é afetada pelas matrículas do ensino fundamental de nove anos.

Esta alteração na idade ideal para frequentar a pré-escola torna mais complexo entender a relação entre matrículas e demanda para este nível de ensino. No começo do período analisado, as pré-escolas tinham como público ideal crianças de quatro a seis anos de idade. Entretanto a lei 11.276/06 estabeleceu que até 2010 todos os municípios deveriam ter se adaptado para oferecer nove anos de ensino fundamental às suas crianças. Isto implica que a população em idade ideal para se matricular nas pré-escolas passou a ser as crianças com quatro ou cinco anos de idade. Desta forma, a população em idade ideal para cursar este nível de ensino diminuiu e aumentou o percentual de crianças em idade ideal atendida. $O$ atendimento à demanda por vagas em pré-escolas que estava em torno de $40 \%$ em 2000 passa para pouco mais de 60\% em 2012, apesar da diminuição no número absoluto de matrículas neste nível de ensino.

Abaixo são apresentados dados sobre o comportamento das diferentes redes de ensino durante o período destacado:

\footnotetext{
${ }^{3}$ A lei 11.274/06 estabeleceu a implementação gradual do ensino fundamental de 9 anos a partir da incorporação de crianças de 6 anos ao ensino fundamental. A lei previa que até o ano de 2010 todos os entes federados deveriam estabelecer a obrigatoriedade do ensino fundamental de 9 anos. Entretanto, em 2012 ainda é possível observar no Censo Escolar municípios que matriculam crianças de 6 anos no ensino pré-escolar, apesar de em número cada vez menor.
} 
Gráfico 1.9: Matrículas em Pré-Escolas por Rede de Ensino

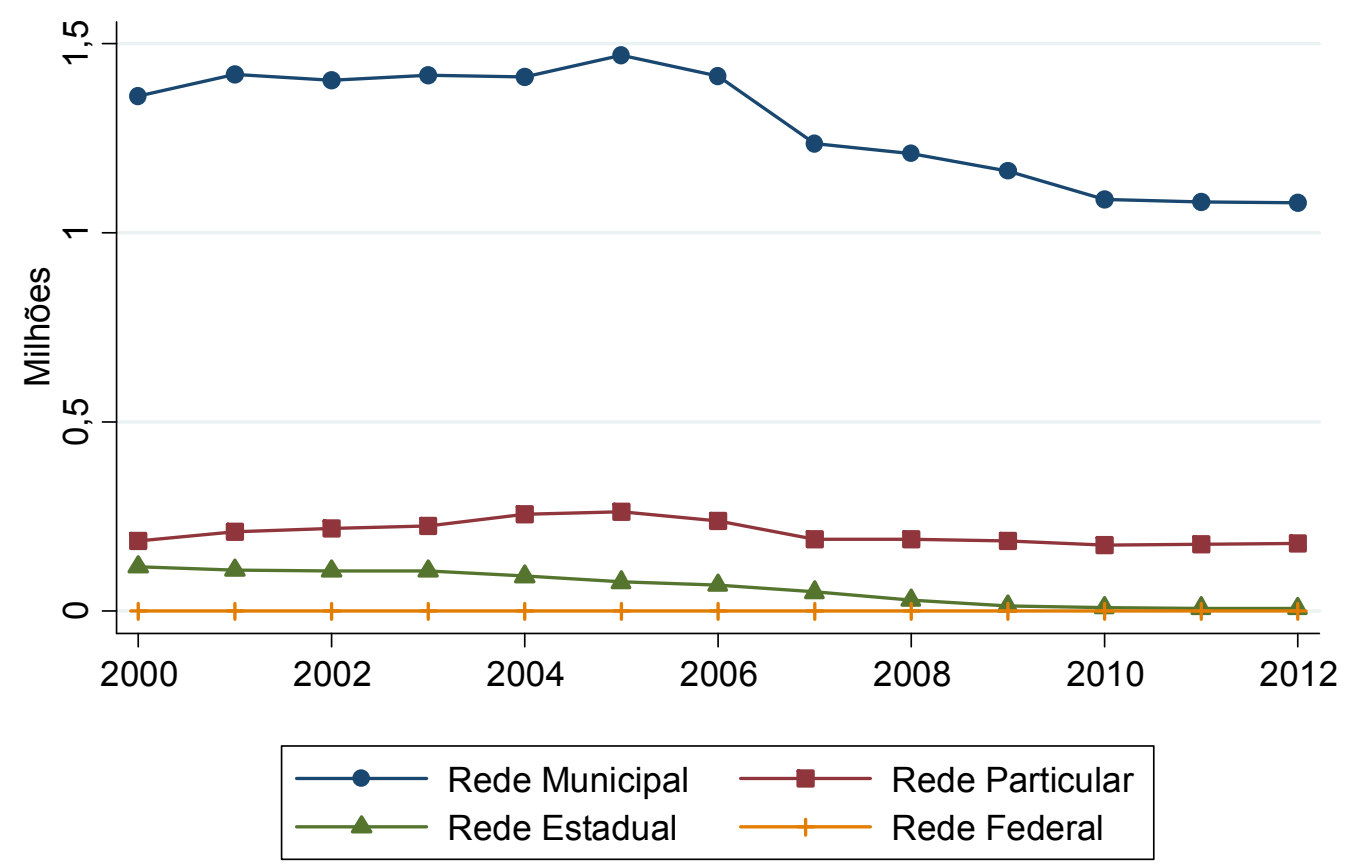

Fonte: Censo Escolar (2000 - 2012).

O gráfico 1.9 mostra que o comportamento das matrículas observado no gráfico 1.6 foi fortemente influenciado pela rede municipal de ensino. Observa-se, também, que a rede municipal e a rede estadual apresentaram declínio ao longo do período, embora cada uma apresente trajetória própria. A rede particular oscila para cima até 2005 e sofre decréscimo em 2006 e 2007, mantendo-se estável desde então e permanecendo em um patamar bem próximo de seu valor inicial. Novamente, a rede federal se mostra irrelevante. O declínio no número de matrículas exibido pela rede municipal, sem reflexo positivo nas matrículas das outras redes de ensino, é decorrente da variação demográfica ocorrida no período, que resultou em declínio das crianças em idade ideal para cursar este nível de ensino no período de 2006 a 2010. O declínio das matrículas na rede municipal também pode ser afetado pela população dos municípios pequenos terem passado a matricular seus filhos em pré-escolas dos municípios maiores.

A seguir são apresentados dados sobre a participação relativa das diferentes redes de ensino no total de matrículas oferecidas no ensino pré-escolar: 
Gráfico 1.10: Participação das Redes de Ensino no Total de Matrículas em Pré-Escolas

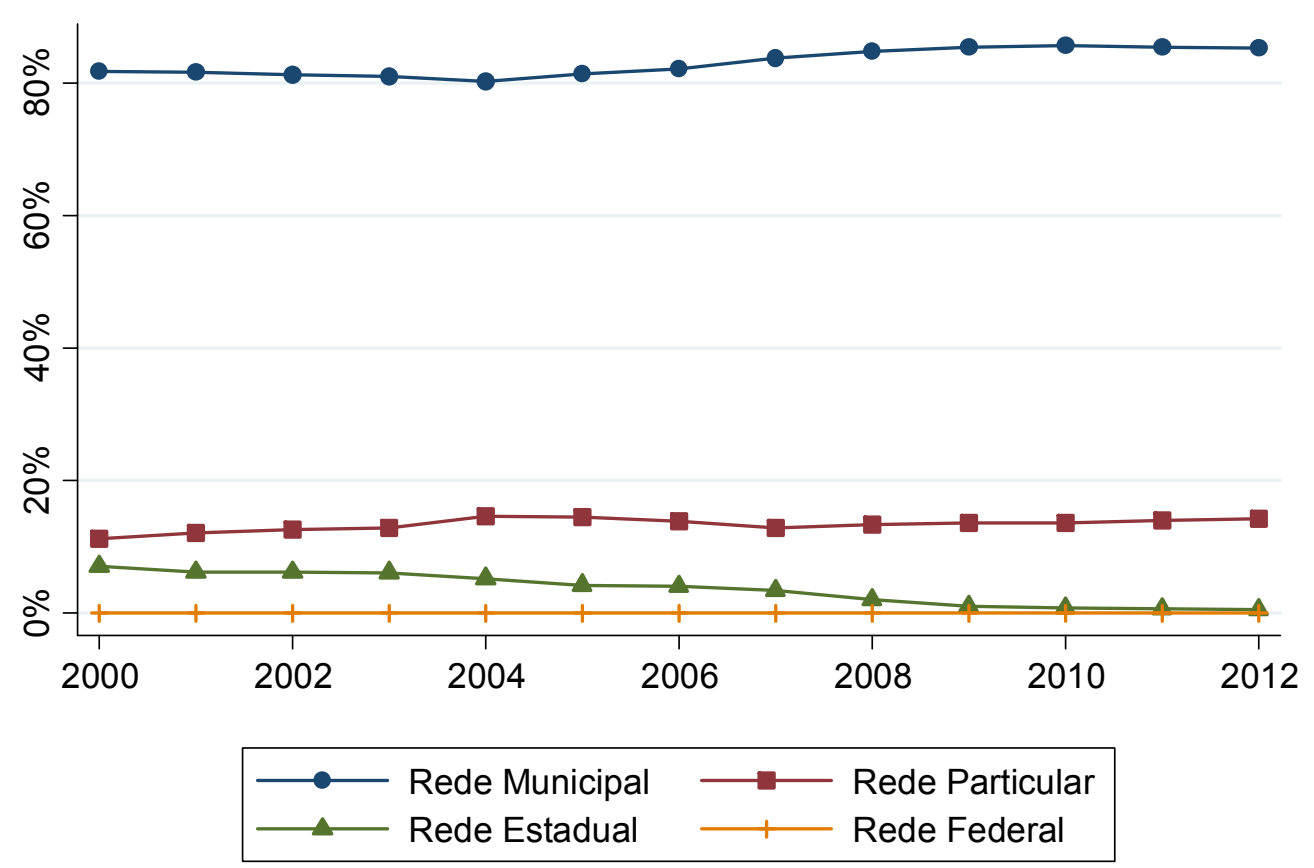

Fonte: Censo Escolar (2000 - 2012).

O declínio no número de matrículas da rede estadual fez com que a rede municipal apresentasse aumento significativo em sua participação relativa no percentual de matrículas oferecidas, mesmo tendo enfrentado queda em seu número absoluto de matrículas. Esta mesma observação é válida para a rede particular que manteve ao final do período número de matrículas bastante similar àquele apresentado em 2000, mas teve sua participação relativa aumentada devido ao declínio das redes estaduais.

\subsubsection{Ensino Fundamental}

O ensino fundamental difere dos demais níveis de ensino por seu acesso estar praticamente universalizado (AGUIAR, 2010; CAMPOS; CRUZ, 2009). Observa-se nos gráficos a seguir que tem ocorrido diminuição em ritmo quase constante do número absoluto de matrículas neste nível de ensino. Isto somado ao fato de que a razão entre o número de matrículas no ensino fundamental e a população em idade ideal para frequentar este nível de ensino demonstra um número maior de matrículas do que o esperado. O total de matrículas que equivale a mais de $100 \%$ da população em idade 
ideal para frequentar este nível de ensino reflete o desvio idade-série presente no ensino fundamental somado à universalização do acesso. Ao longo dos anos, o total de matrículas em relação à população em idade ideal diminuiu e se aproximou de 100\%, o que também sugere melhora no fluxo e diminuiç̧ão da distorção idade-série.

Gráfico 1.11: Matrículas no Ensino Fundamental

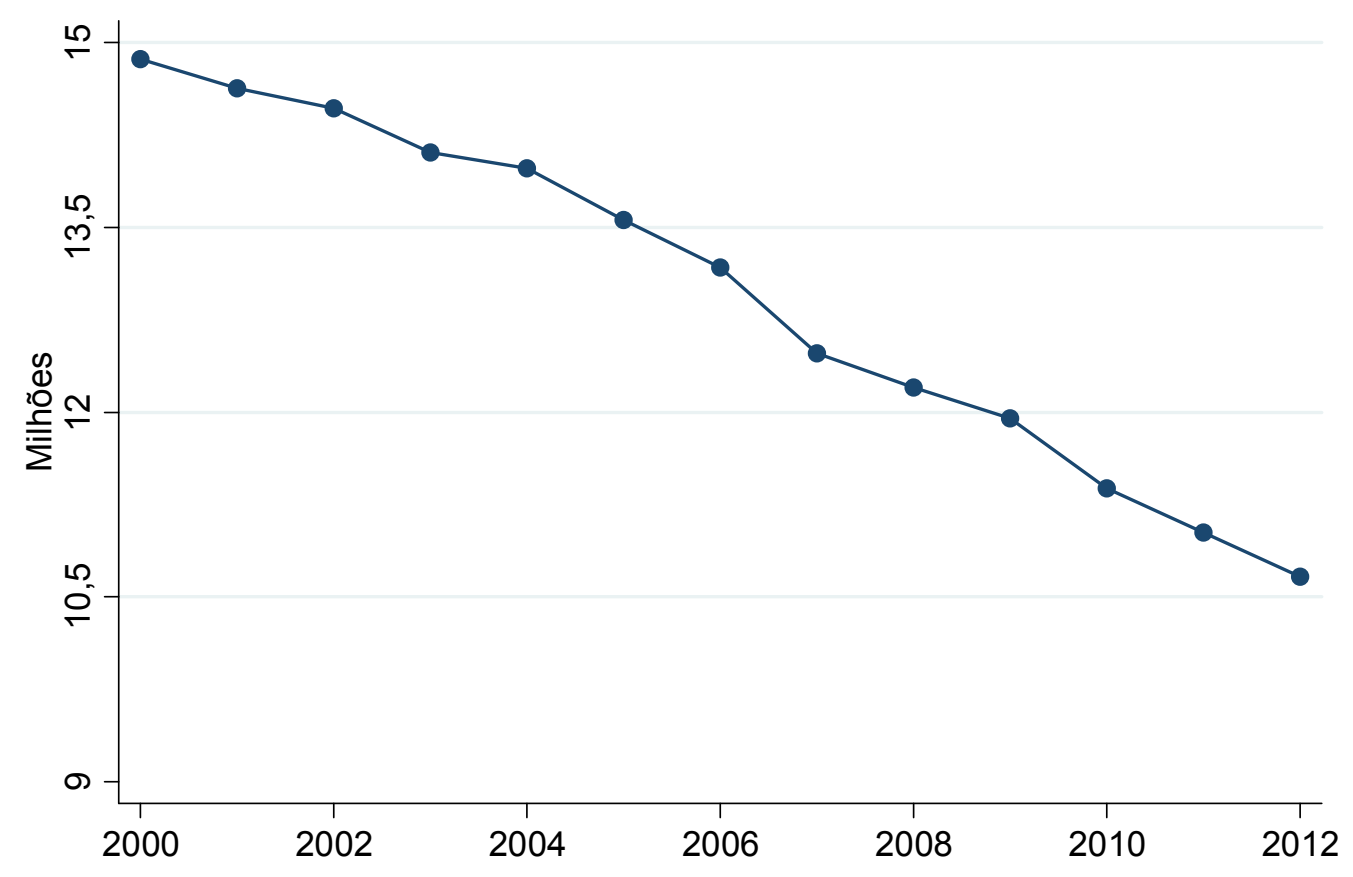

Fonte: Censo Escolar (2000 - 2012). 
Gráfico 1.12: Matrículas no Ensino Fundamental de 8 e 9 Anos

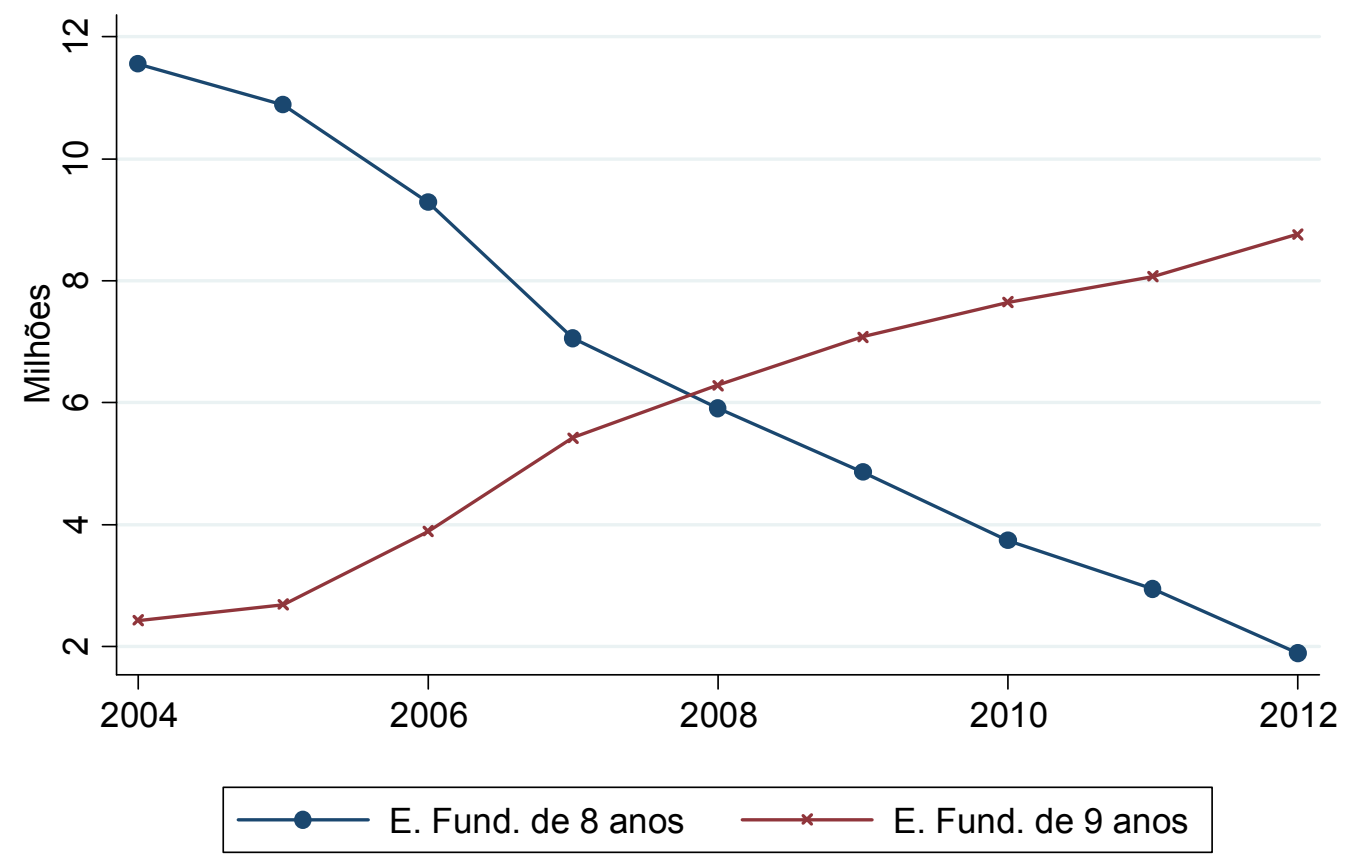

Fonte: Censo Escolar (2000 - 2012).

Gráfico 1.13: População em Idade Ideal para o Ensino Fundamental

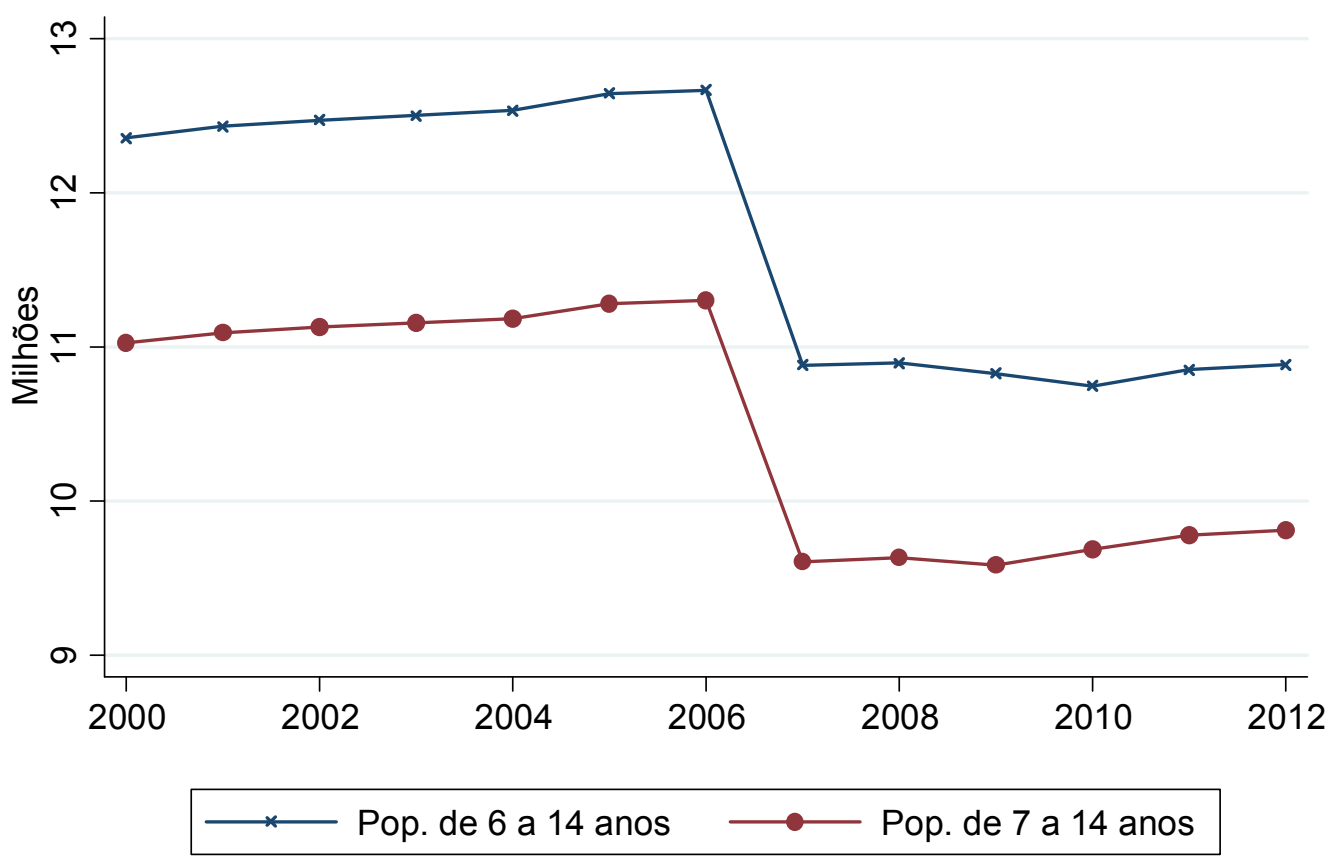

Fonte: Estimativas Populacionais do DATASUS (2000 - 2012). 
Gráfico 1.14: Demanda Atendida por Vagas no Ensino Fundamental

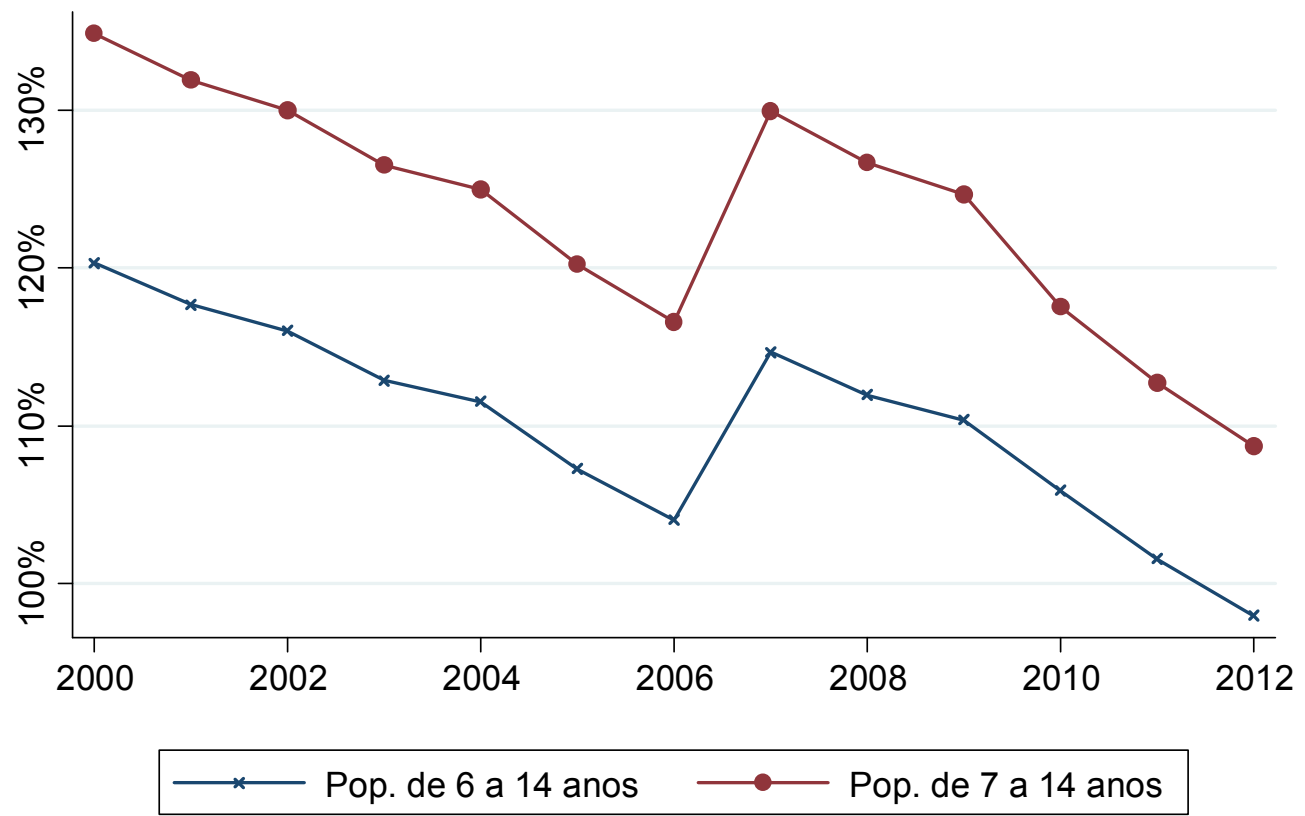

Fonte: Censo Escolar (2000 - 2012) e

Estimativas Populacionais do DATASUS (2000 - 2012).

O número de matrículas por rede de ensino mostra que cada uma das redes teve comportamento próprio durante o período. A rede municipal apresentou leve aumento até 2004, mas passou a declinar de 2005 em diante. A rede estadual se manteve em ritmo constante de declínio, tendo em 2012 metade dos alunos que tinha em 2000. A rede particular sofreu leve aumento e a rede federal permaneceu com oferta próxima de zero. 
Gráfico 1.15: Matrículas no Ensino Fundamental por Rede de Ensino

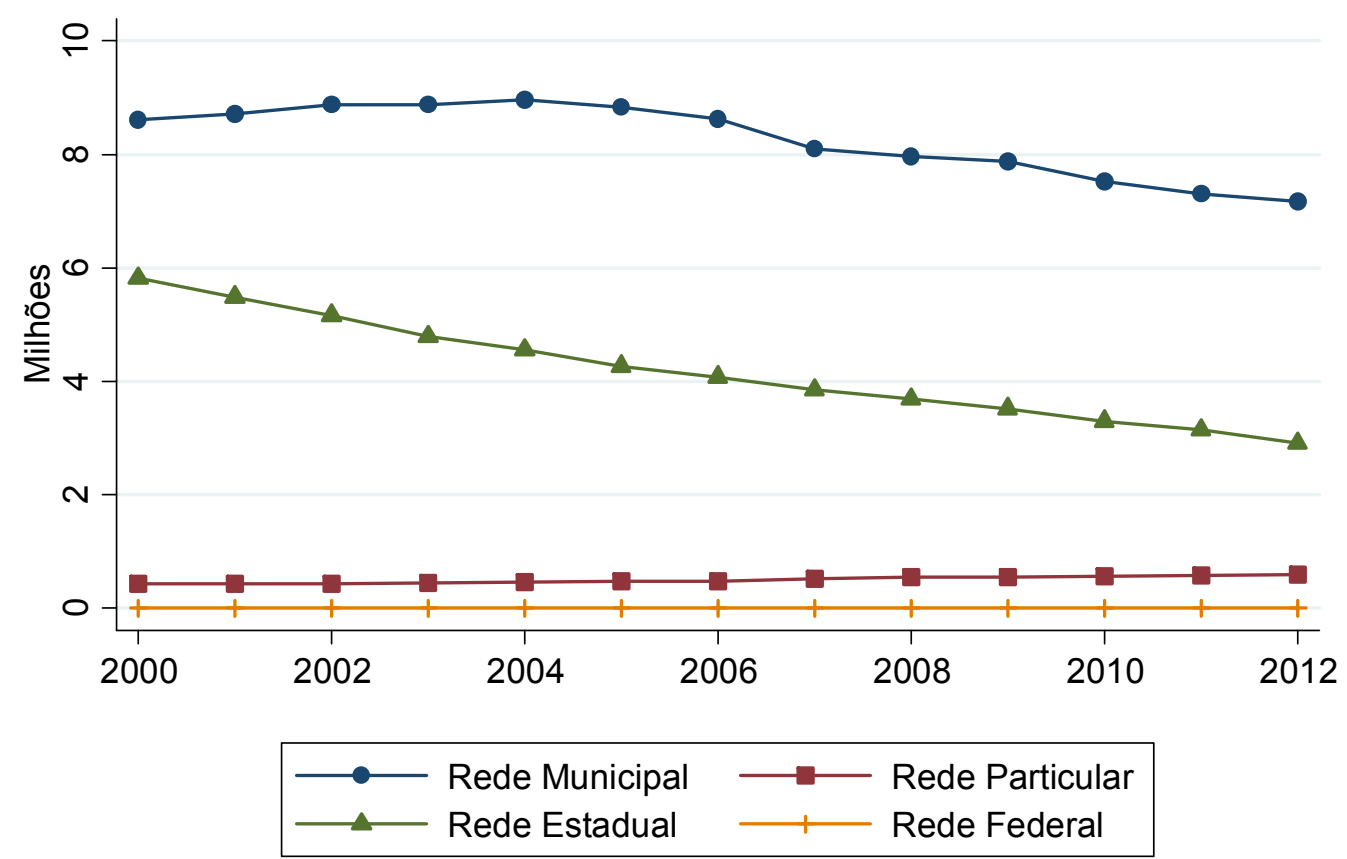

Fonte: Censo Escolar (2000 - 2012).

Gráfico 1.16: Participação das Redes de Ensino no Total de Matrículas no Ensino Fundamental

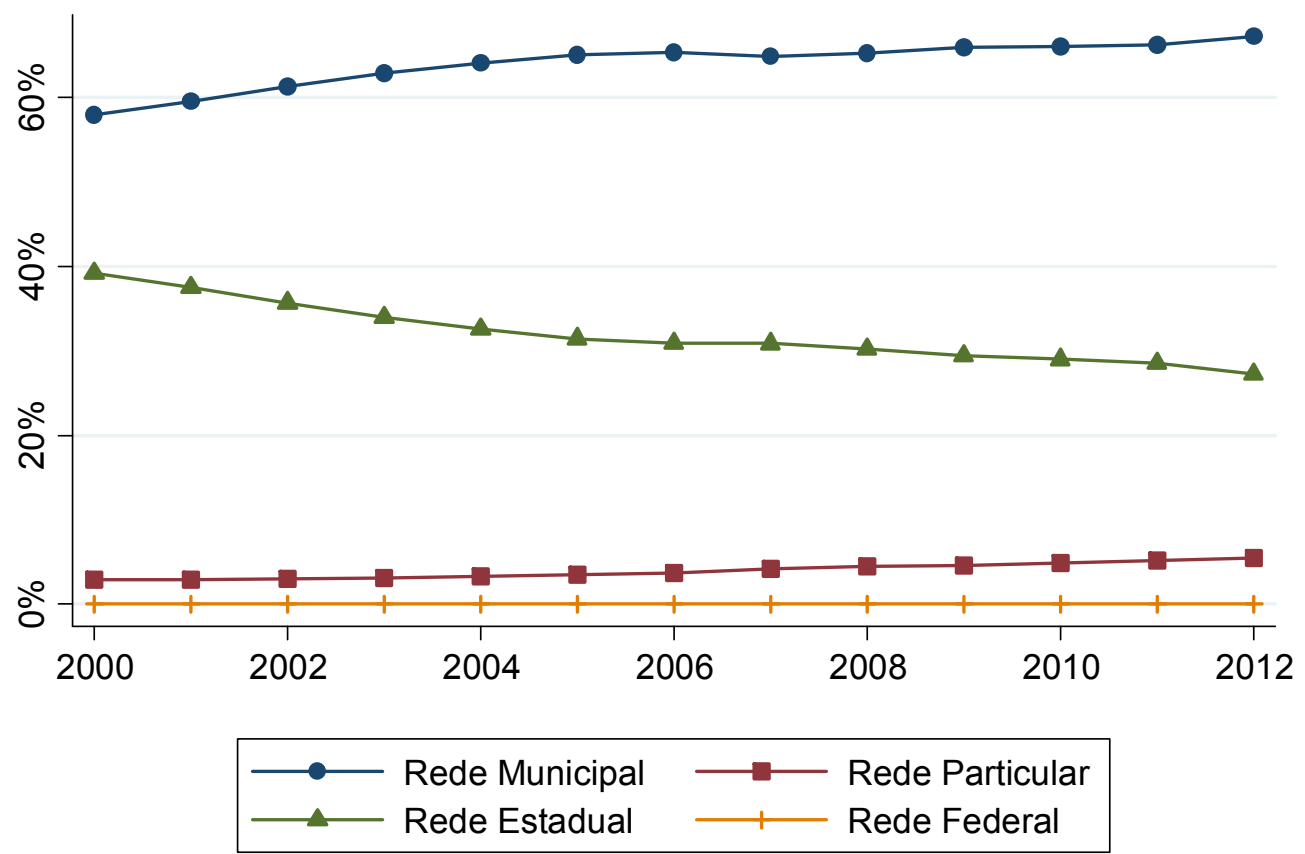

Fonte: Censo Escolar (2000 - 2012). 
A rede municipal é a principal ofertante deste serviço durante o período analisado, a rede estadual tem sua participação cada vez mais reduzida, a rede particular tem papel pequeno, porém crescente e a rede federal tem participação insignificante. A rede estadual tem presença forte e certamente influencia nas decisões dos prefeitos em expandir as redes municipais. Esta breve observação do comportamento das diferentes redes de ensino mostra que a rede estadual é essencial para entender o comportamento da rede municipal de ensino fundamental.

\subsubsection{Ensino Médio}

Por fim, examinemos dados sobre as matrículas, a população em idade ideal e a demanda atendida para o ensino médio.

Gráfico 1.17: Matrículas no Ensino Médio

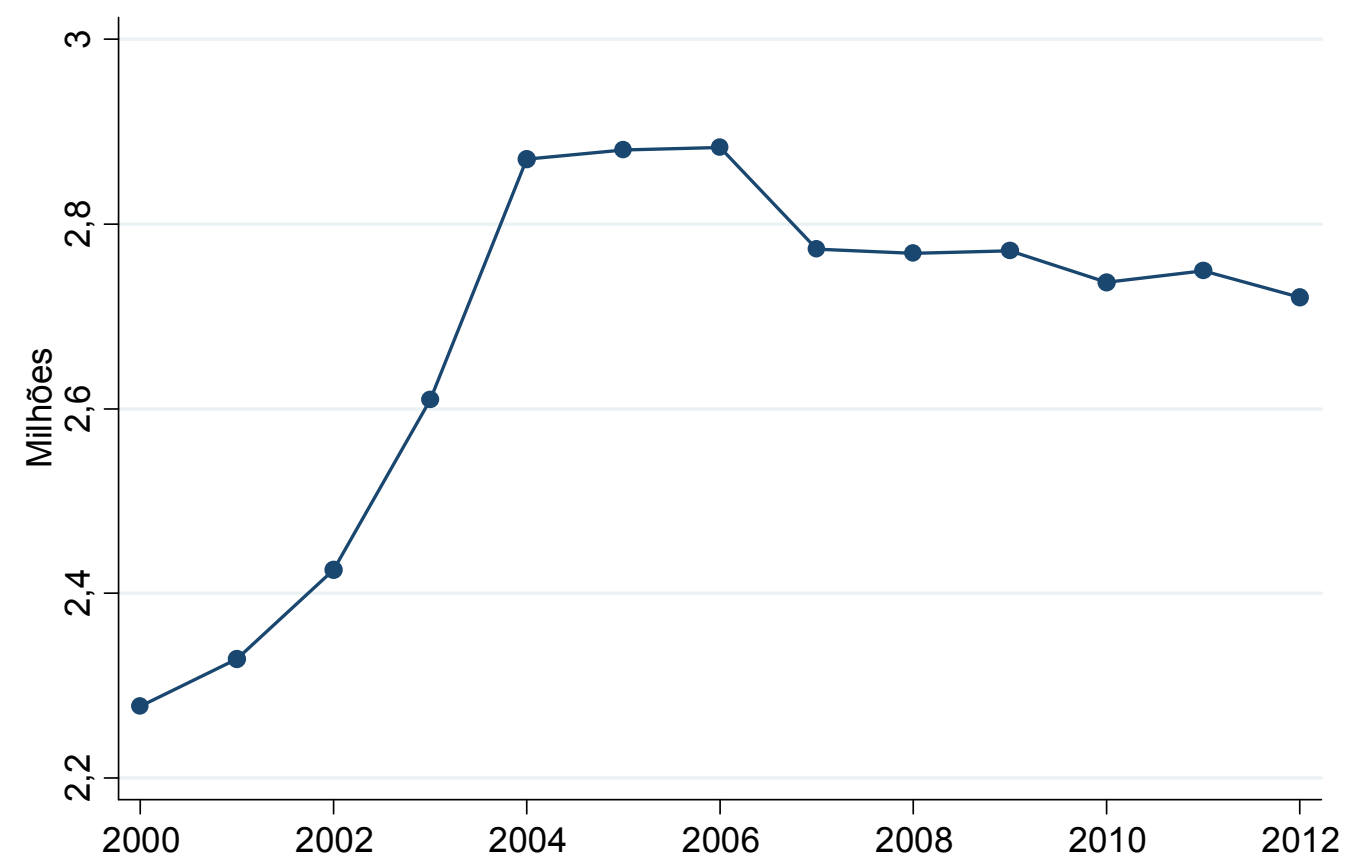

Fonte: Censo Escolar (2000 - 2012). 
Gráfico 1.18: População de 15 a 17 anos

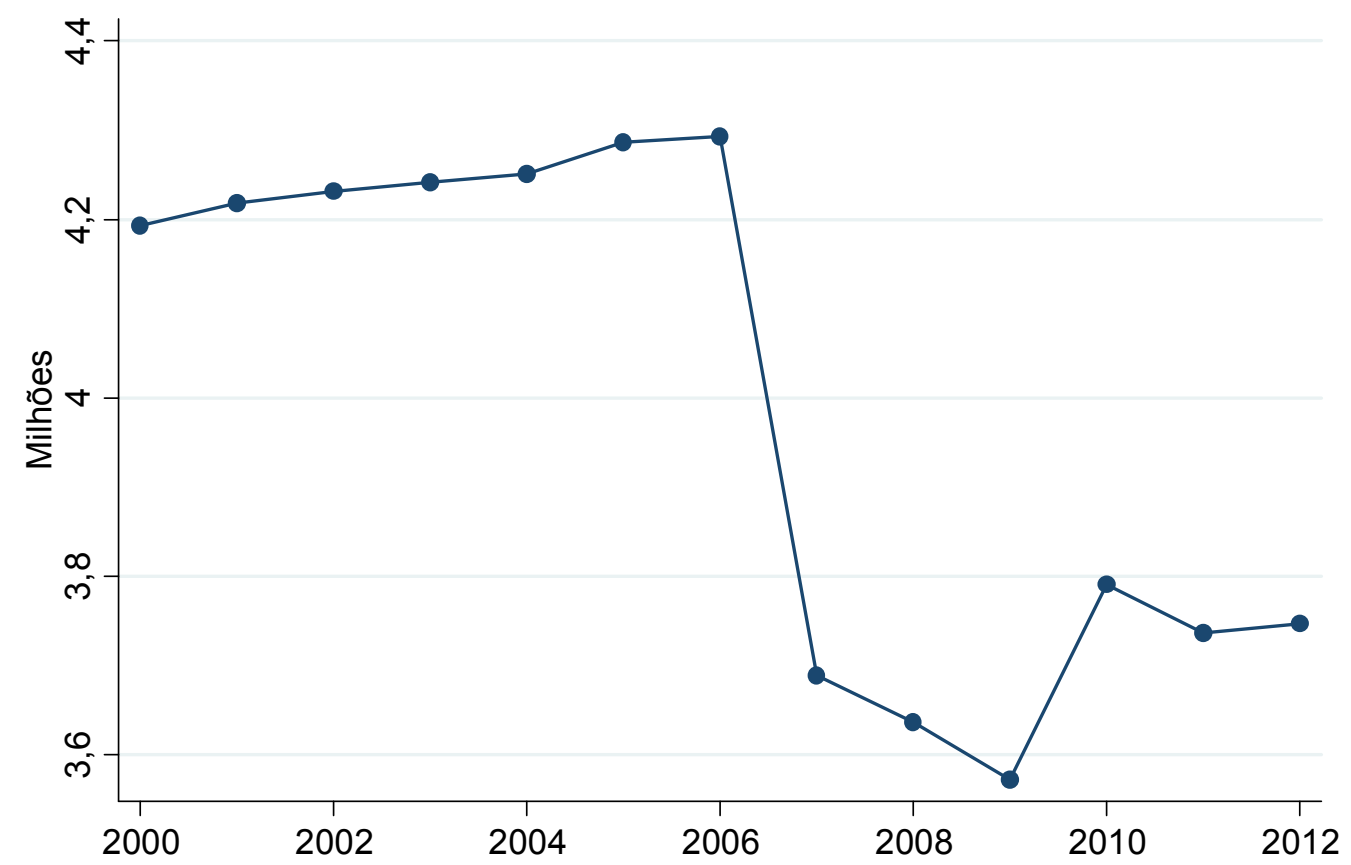

Fonte: Estimativas Populacionais do DATASUS (2000 - 2012).

Gráfico 1.19: Demanda Atendida por Vagas no Ensino Médio

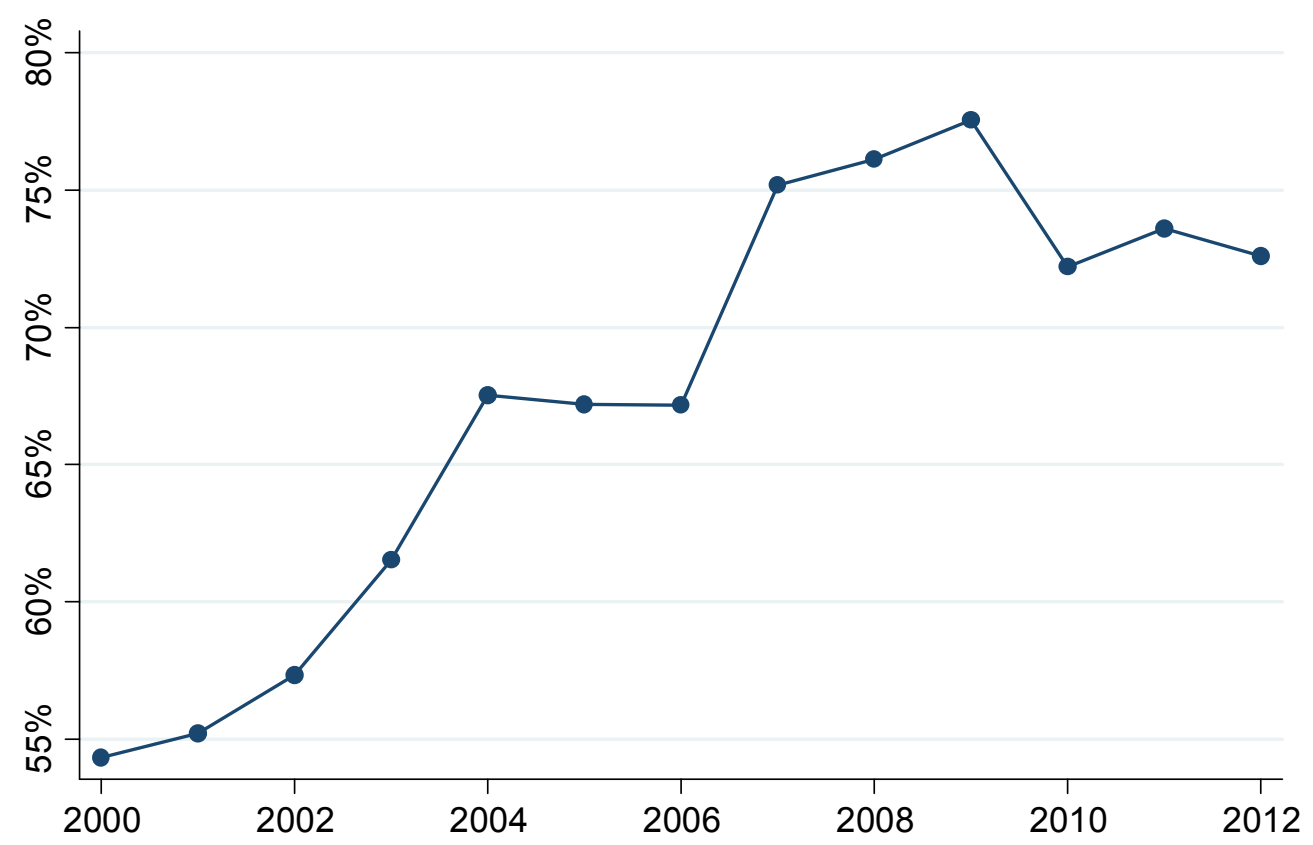

Fonte: Censo Escolar (2000 - 2012) e

Estimativas Populacionais do DATASUS (2000 - 2012). 
As matrículas no ensino médio não seguem trajetória linear. Elas crescem exponencialmente no período de 2000 a 2004, apresentam estabilidade em 2005 e 2006, queda em 2007 e a partir de 2008 apresentam estabilidade com leves declínios. Destes movimentos, o único que certamente reflete uma mudança demográfica é a queda em 2007, que traduz para o número de matrículas a queda ocorrida na população em idade ideal para cursar este nível de ensino.

O gráfico abaixo mostra como as diferentes redes de ensino se dividem na oferta de matrículas para o ensino médio:

Gráfico 1.20: Matrículas no Ensino Médio por Rede de Ensino

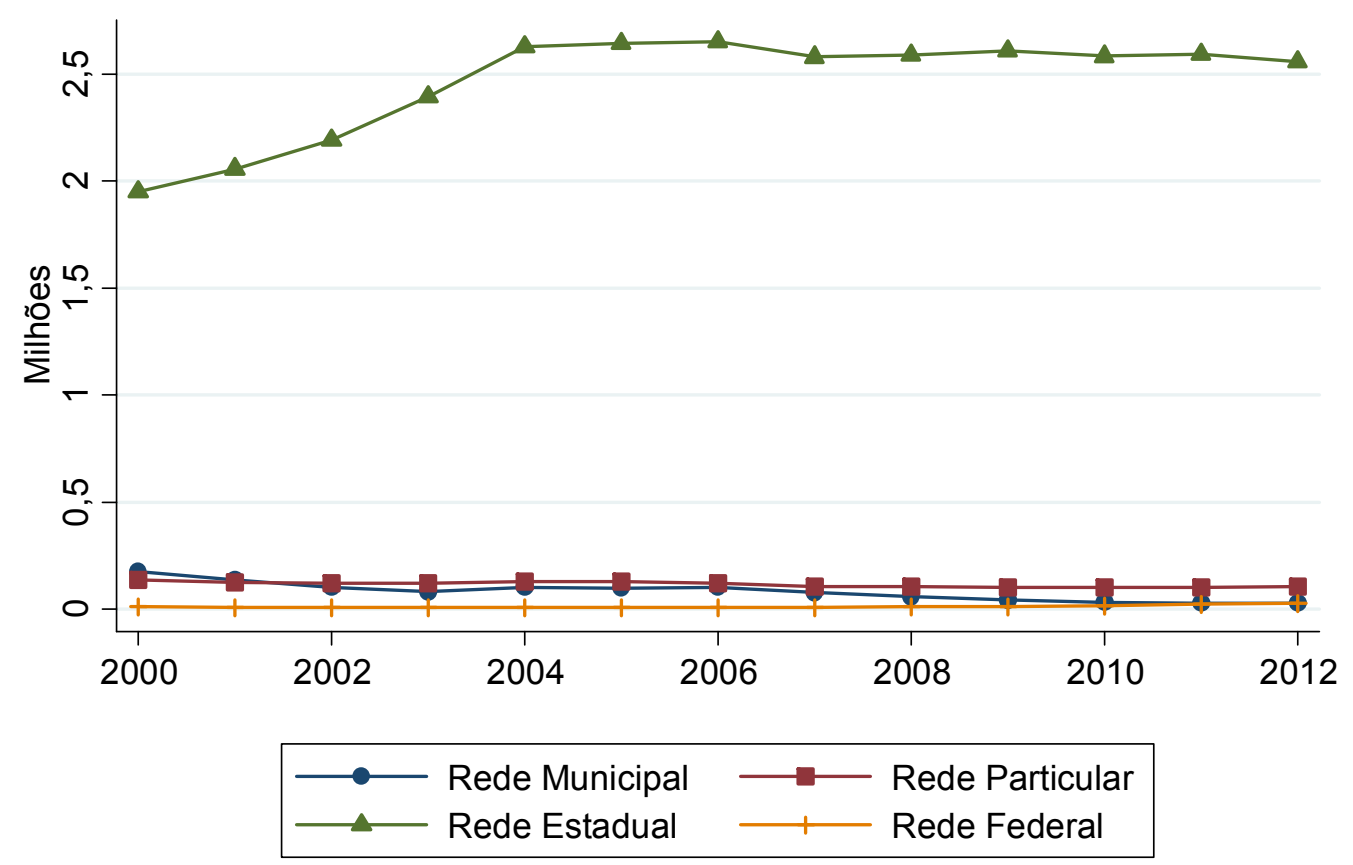

Fonte: Censo Escolar (2000 - 2012).

É clara a predominância da rede estadual na oferta de matrículas para o ensino fundamental. Chama a atenção o fato de que a rede municipal no ano de 2012 tem participação residual na oferta de matrículas para o ensino médio. $O$ gráfico a seguir, com a participação relativa de cada uma das redes de ensino confirma esta conclusão. 
Gráfico 1.21: Participação das Redes de Ensino no Total de Matrículas no Ensino Médio

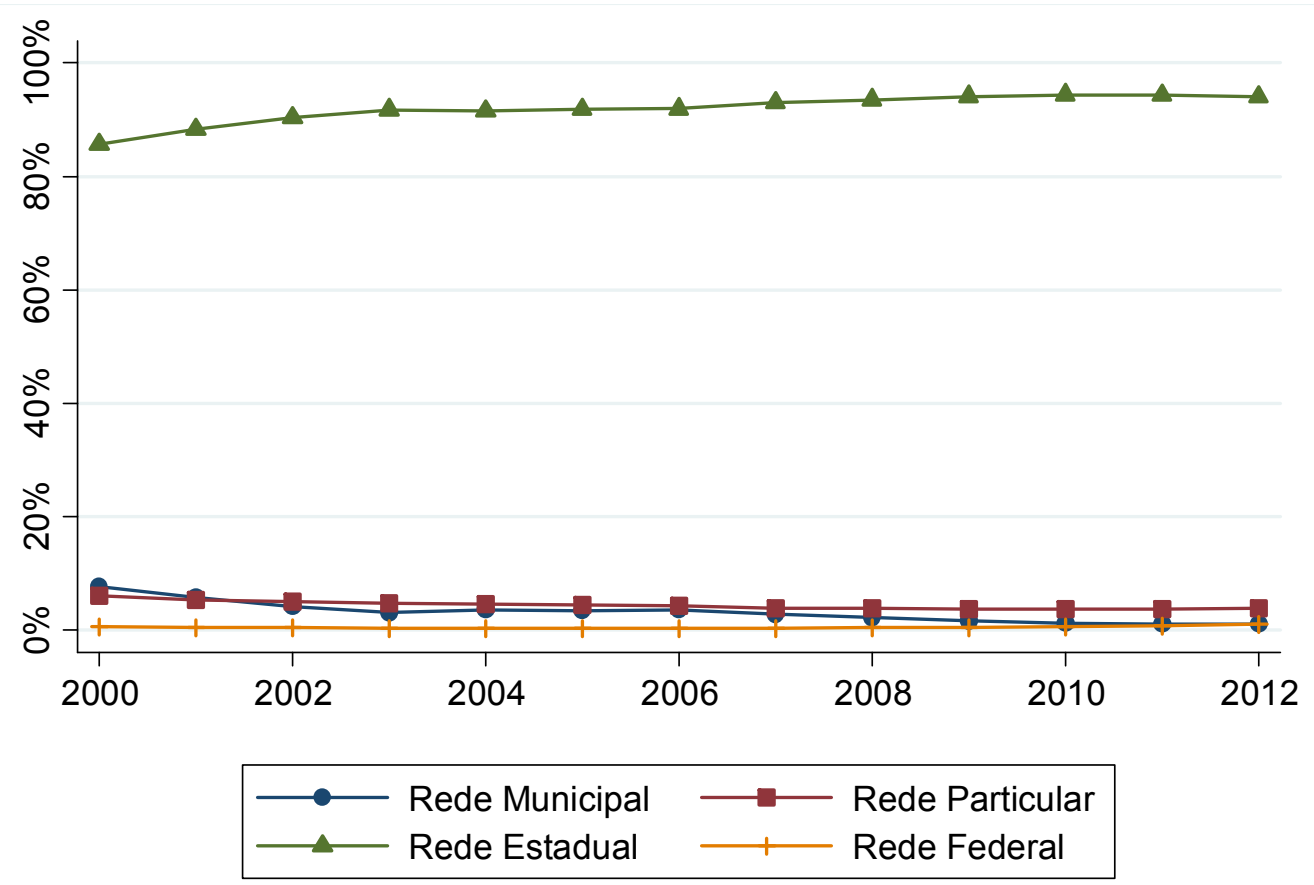

Fonte: Censo Escolar (2000 - 2012).

Diferentemente do ocorrido para os outros níveis de ensino, no ensino médio a rede municipal tem presença consideravelmente pequena, chegando a ser menor que a rede federal. Logo, diferentemente das creches, pré-escolas e ensino fundamental, no ensino médio o papel do governo local tende a ser insignificante. As decisões dos prefeitos, portanto, pouco afetam este nível de ensino. Assim, pesquisar o ensino médio faz mais sentido quando o foco da análise é o papel dos governadores no plano estadual, e não o papel dos prefeitos nos municípios.

\subsection{Gastos em Educação}

Esta seção analisa o gasto em educação nos municípios. Examina este item de gasto em relação ao total da receita orçamentária, discriminando por subfunções. Pode-se argumentar que estes indicadores não representam fielmente as preferências dos prefeitos, uma vez que gastos não revelam políticas (ESPING-ANDERSEN, 1991). Entretanto, eles ainda são informativos do papel dos prefeitos e de seus partidos nas escolhas no nível local. Os estímulos da União para expandir as matrículas municipais 
poderiam ser ignorados caso o prefeito estivesse disposto a arcar com os custos desta ação.

O efeito significativo das políticas do governo federal sobre os demais entes federados pode ser examinado pela determinação federal dos valores mínimos por aluno a serem gastos $^{4}$, como mostra o gráfico abaixo ${ }^{5}$ para o período 1998 a 2012:

\footnotetext{
${ }^{4}$ A determinação destes valores se deu mediante decretos presidenciais e portarias interministeriais.

${ }^{5}$ A partir de 1999, o governo federal passou a distinguir o ensino fundamental em anos iniciais e anos finais. O valor exibido é uma média dos dois valores. A partir de 2005, além da divisão já existente no ensino fundamental, o governo federal passou a determinar valores diferentes para o ensino fundamental rural e para o urbano. Novamente, os valores exibidos são a média resultante dos valores dos anos iniciais e finais do ensino fundamental e do ensino fundamental urbano e rural. A partir de 2006, o governo federal passou a declarar valores mínimos no gasto por aluno específicos para cada estado do país. 0 valor exibido no gráfico a partir de então também é a média dos valores mínimos que cada estado deveria gastar. O exercício de tirar a média do gasto mínimo por município retorna valores muito semelhantes aos exibidos. Os valores do gráfico estão inflacionados tendo o ano de 2012 como ano base.

As fontes consultadas para a criação deste gráfico foram os decretos 2.440/97, 2.935/99, 3.326/99, $3.742 / 01,4.103 / 02,4.580 / 03,4.861 / 03,4.966 / 04$ e 5.299/04, as portarias interministeriais 1.030/07, $1.027 / 08,221 / 09,1227 / 09,477 / 11$ e $1.809 / 11$ e os dados disponíveis em "Valor por aluno/ano, por Estado e Distrito Federal, do Fundo de Manutenção e Desenvolvimento do Ensino Fundamental e de Valorização do Magistério - 2006", nota disponível em: http://www.fnde.gov.br/arquivos/category/54consultas?download=3083:valor-aluno-estado2006-fundef acessada em 06/07/2013.

Os valores mínimos de gasto por aluno/ano são definidos em decretos e em portarias devido às diretrizes estabelecidas nas leis $9424 / 96$ e 11.494/07, leis que regulamentam o FUNDEF e o FUNDEB, respectivamente.
} 
Gráfico 1.22: Valor Mínimo de Gasto por Aluno/Ano Estabelecido pelo Governo Federal

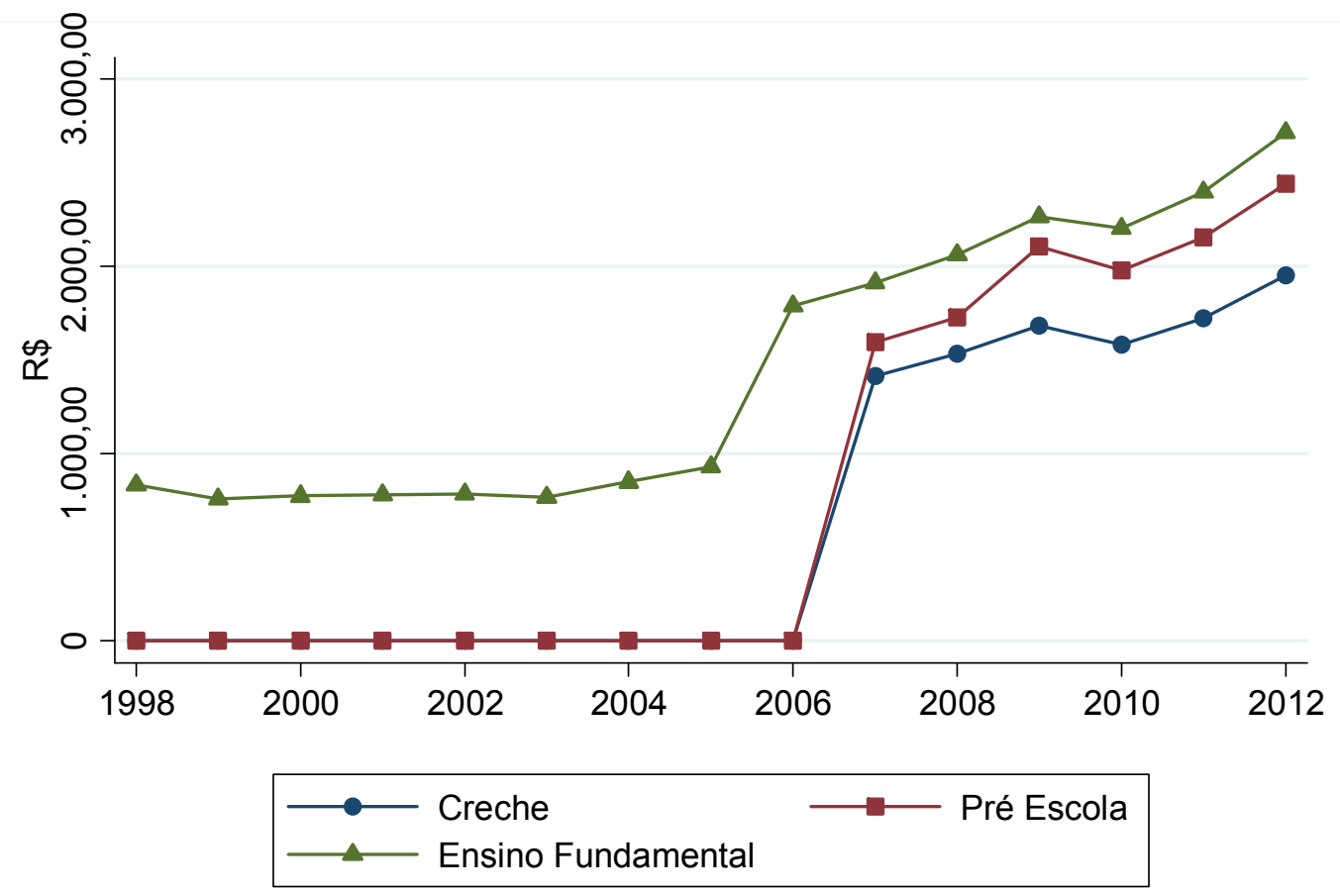

Fonte: diversos decretos presidenciais e portarias interministeriais.

Em conjunto com as informações sobre a trajetória das matrículas, estes dados confirmam que, durante o período de vigência do FUNDEF, o governo federal estabeleceu valores mínimos de gastos por aluno abaixo do legalmente estabelecido pela própria lei do FUNDEF (OLIVEIRA, 2012; PINTO, 2007; RODRIGUEZ, 2001; VAZQUEZ, 2005), pois estes valores tenderam apenas a corrigir a inflação. Apenas a partir de 2006 houve aumento considerável do valor mínimo estabelecido por aluno do ensino fundamental. Também revelam a importância do FUNDEB para os demais níveis de ensino uma vez que valores mínimos a serem gastos por aluno/ano de creches e préescolas também passam a ser determinados pela legislação federal.

O gráfico a seguir mostra que de 2002 a 2012, o percentual da receita orçamentária destinada à educação nos municípios com até 50 mil moradores tendeu a oscilar próximo de $29 \%$ de seu total. 
Gráfico 1.23: Percentual da Receita Orçamentária Destinado à Educação nos Municípios com até 50 Mil Moradores

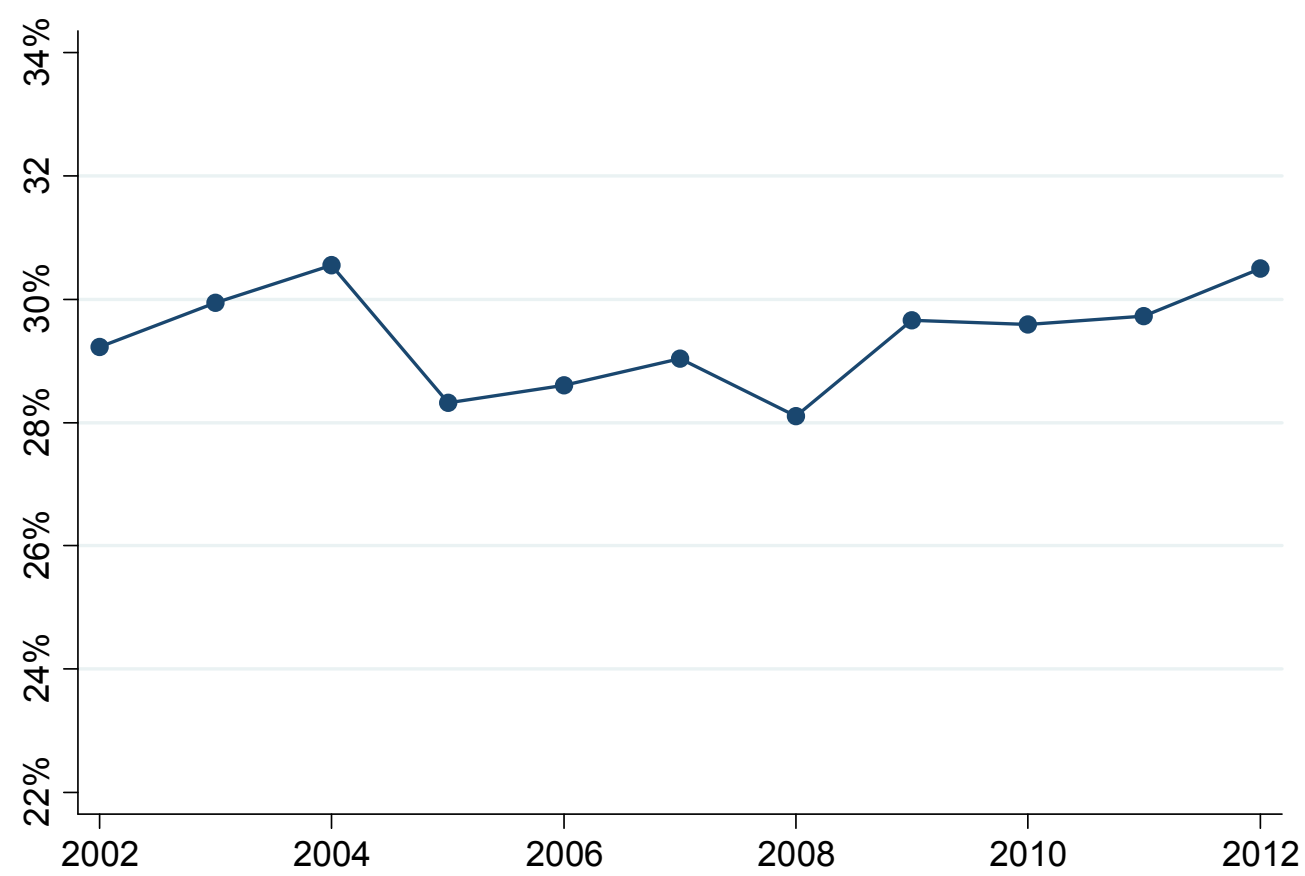

Fonte: Finanças do Brasil (FINBRA - Secretaria do Tesouro Nacional).

Entretanto, esta média não revela prioridades de política. Estas podem ser observadas com base no gasto nas subfunções da educação. O percentual dos gastos em ensino fundamental e educação infantil são bons indicadores das prioridades dos governos municipais, como mostra o gráfico a seguir. 
Gráfico 1.24: Percentual dos Gastos em Educação Destinado ao Ensino Fundamental nos Municípios com até 50 Mil Moradores

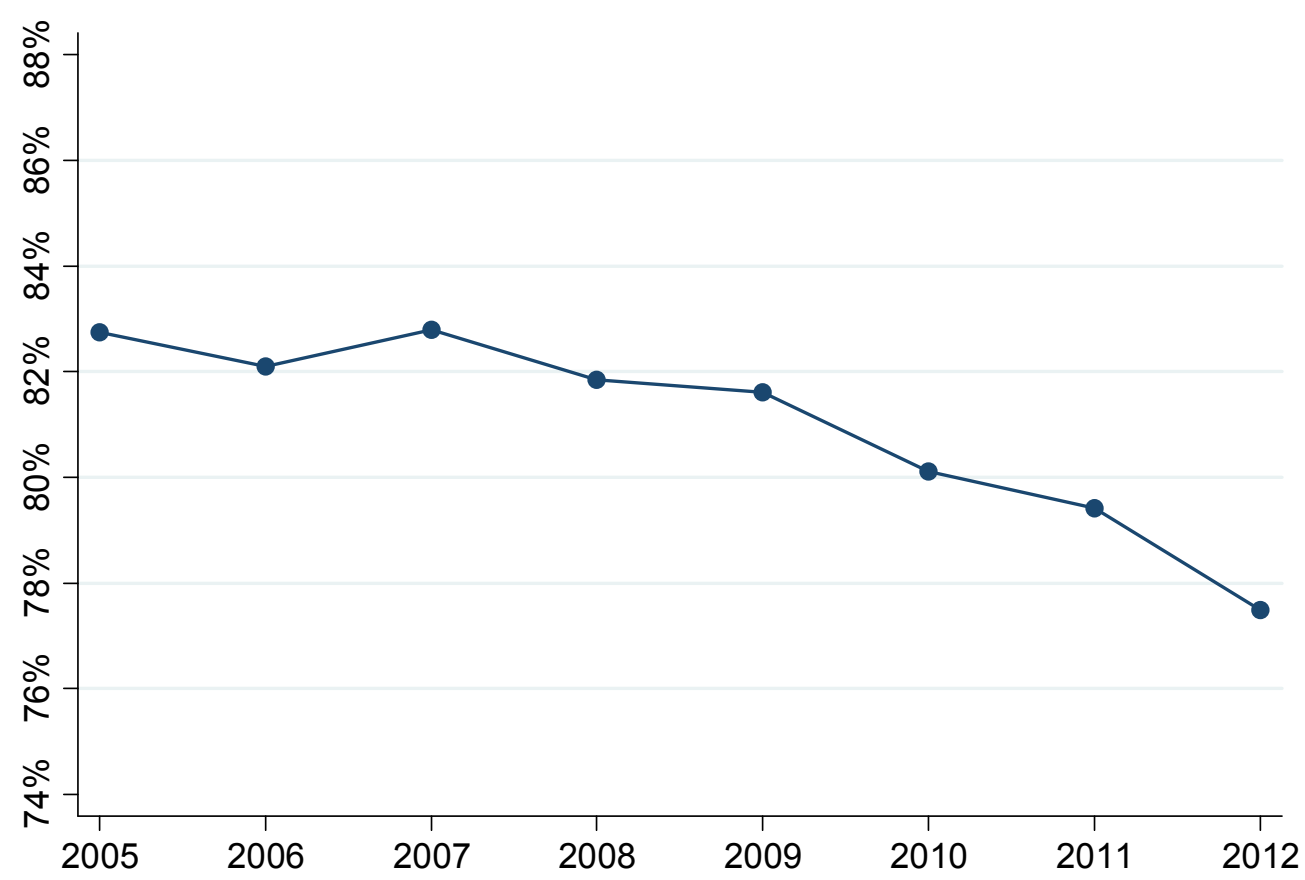

Fonte: Finanças do Brasil (FINBRA - Secretaria do Tesouro Nacional).

Gráfico 1.25: Percentual dos Gastos em Educação Destinado à Educação Infantil nos Municípios com até 50 Mil Moradores

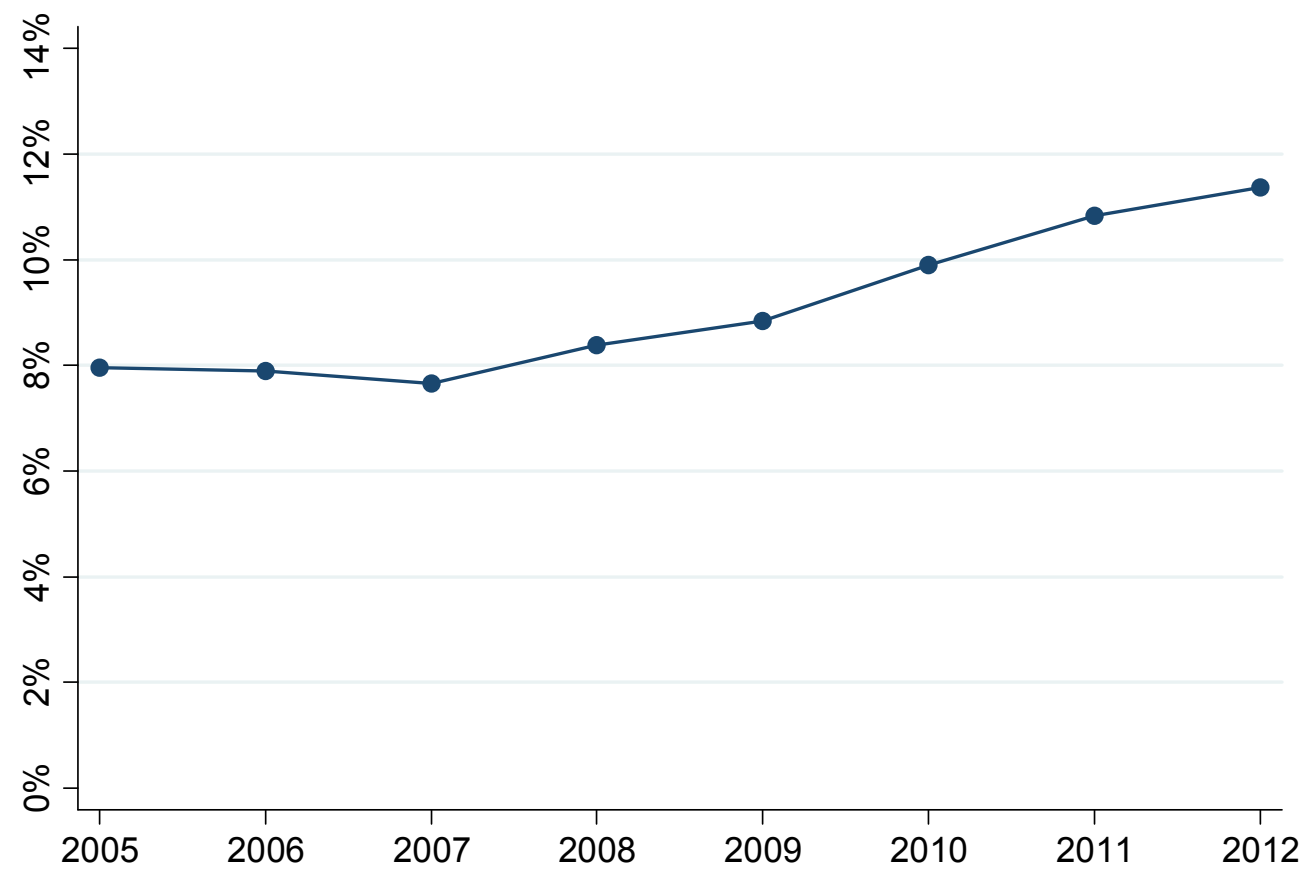

Fonte: Finanças do Brasil (FINBRA - Secretaria do Tesouro Nacional). 
A partir de 2008 começa a ocorrer um declínio na proporção dos gastos destinados ao ensino fundamental. Este declínio favorece o gasto em educação infantil. Estes dados sugerem que o FUNDEB influenciou as escolhas dos prefeitos na alocação de seus gastos em educação. Sugerem ainda que as creches foram as principais beneficiárias do aumento no gasto em educação infantil, dado que as matrículas em creches municipais cresceram significativamente a partir de 2008 ao passo que pré-escolas municipais passaram por declínio neste mesmo período.

\subsection{Conclusão}

O governo federal tem um papel importante nas escolhas da política local de educação, mas sua participação é irrelevante no que diz respeito à oferta de ensino. A participação da rede federal em creches, escolas de ensino pré-escolar, fundamental e médio é residual no total de matrículas oferecidas no país. Portanto, o governo federal influencia a política local de educação através de sua legislação, mas não através de sua própria rede de ensino.

O mesmo não se pode dizer da rede estadual de ensino. Apesar de a rede estadual não ter presença significativa na oferta de creches ou pré-escolas, tem forte participação na oferta de ensino fundamental. A despeito da redução em tamanho, a rede estadual de ensino fundamental continua importante para entender o comportamento das redes municipais de ensino. Uma vez que o ensino fundamental foi universalizado (AGUIAR, 2010; CAMPOS; CRUZ, 2009) e a rede estadual não se retrai por igual em todos os estados, torna-se interessante observar qual a relação entre a filiação partidária do governador e a trajetória das redes municipais de ensino.

O comportamento das matrículas na rede particular de ensino mostra que esta rede não deve ser ignorada nas análises sobre a oferta de educação. A participação expressiva da rede particular na oferta de vagas em creches e pré-escolas the confere lugar de destaque, juntamente com a rede municipal. É preciso entender melhor como estas redes interagem entre si para se ter uma boa compreensão de como funciona a política local de educação. 
Por fim, conclui-se que o município é o principal agente da política de educação no que diz respeito ao atendimento em creches, pré-escolas e ensino fundamental. O ensino médio é o único nível de ensino em que o governo local não tem presença significativa. Este é o objeto de análise mais indicado para um estudo com foco no governo estadual. Assim, ele não é explorado nos capítulos seguintes.

Em síntese, a política local de educação deve ser entendida como parte de um quadro maior, estruturado pela legislação e pelas políticas do governo federal. Porém, as políticas dos governos estaduais não podem ser ignoradas, em particular a oferta de matrícula, por sua interação com as redes de ensino municipais e particulares. Em interação com a demanda existente, estes são elementos essenciais para o entendimento da política local de educação, que vá além de análises extensivas baseadas em estudos de caso. Uma compreensão geral destes processos requer uma análise que envolva a maioria dos municípios brasileiros. No capítulo seguinte é apresentada a literatura sobre partidos políticos e políticas públicas com a qual este trabalho dialoga. 


\title{
CAPÍTULO 2: PARTIDOS POLÍTICOS E POLÍTICAS PÚBLICAS - ABORDAGENS CLÁSSICAS E QUESTÕES CONTEMPORÂNEAS
}

\begin{abstract}
"Para o químico, o átomo do hélio era uma molécula porque se comportava como tal desde o ponto de vista da teoria cinética dos gases. Para o físico, o hélio não era uma molécula porque não apresentava um espectro molecular. Podemos supor que ambos falavam da mesma partícula, mas a encaravam a partir de suas respectivas formações e práticas de pesquisa”
\end{abstract}

(Thomas Kuhn)

O foco deste trabalho é a influência que partidos políticos podem exercer sobre escolhas em políticas públicas. A discussão desenvolvida neste capítulo pretende relacionar esta abordagem mais específica com outros estudos clássicos sobre partidos políticos, de modo a propiciar o resgate de visões que são comuns a mais de uma agenda de pesquisa. Assim, neste capítulo, é apresentada ao leitor a literatura sobre partidos políticos com a qual este trabalho dialoga.

Ao observar a influência dos partidos políticos sobre as políticas públicas, há alguns fatores que precisam ser levados em consideração: o interesse do partido em promover determinadas políticas, a influência da demografia e da demanda, os constrangimentos enfrentados pelos partidos na implementação de suas políticas e a configuração do sistema partidário. Este trabalho supõe que estes fatores são os fatores mais relevantes na determinação da influência dos partidos sobre políticas públicas e, mais especificamente, sobre as políticas de educação.

\subsection{Abordagens Clássicas sobre Partidos Políticos}

Apesar de não serem reconhecidos como essenciais aos governos democráticos por teóricos clássicos da política, como Aristóteles ou Tocqueville, os partidos políticos hoje são vistos de forma unânime como indispensáveis ao funcionamento da democracia. A maior parte dos pensadores da época do surgimento dos primeiros partidos se questionava se estes seriam um mal necessário a um Estado livre ou se eles poderiam ser contidos e eliminados. Entretanto, o que ocorreu foi que os partidos precederam as 
teorias que, posteriormente, justificariam sua existência como benéfica à democracia (HOFSTADTER, 1969). Aldrich (1995) mostra como o surgimento dos partidos políticos nos EUA não seguiu apenas critérios ideológicos, mas também estratégicos. Enquanto os parlamentares já se identificavam ideologicamente com determinadas pautas, era necessária uma instituição que coordenasse a ação dos parlamentares para que estes conseguissem obter a aprovação das políticas que buscavam. Segundo Aldrich, os partidos políticos solucionaram um problema de coordenação enfrentado pelos parlamentares. Entretanto, uma visão mais clássica dos partidos políticos associa tanto seu surgimento quanto seu desempenho à representação de classes ou clivagens sociais. Dois clássicos representantes desta literatura são Duverger ([1951]/1980) e Lipset e Rokkan (1967).

O trabalho de Duverger atribui aos partidos políticos o papel central de representar politicamente os diversos grupos presentes na sociedade. Segundo o autor, todo governo é oligárquico e a diferença entre a democracia representativa e outras formas de governo seria o fato de que a primeira permite que o povo seja governado por uma elite oriunda do próprio povo. Caberia aos partidos de massas, portanto, o papel de representar aqueles indivíduos que entraram na arena eleitoral como consequência da expansão do sufrágio. O surgimento dos partidos de massa significou a consolidação da democracia representativa e uma alteração significativa do sistema partidário. Duverger leva em consideração que os sistemas partidários não se desenvolvem todos da mesma maneira e por isso destaca que uma questão essencial para compreender o comportamento dos partidos políticos é considerar o contexto no qual cada um deles surgiu. Neste contexto, a configuração vigente do sistema partidário tem forte influência, pois ela define, por exemplo, se há grupos que podem ser mobilizados para tornar um novo partido eleitoralmente viável.

A questão da representação da sociedade é o que torna o trabalho de Lipset e Rokkan comparável ao de Duverger. Segundo os autores, os partidos 
estabelecer frentes comuns com potenciais inimigos e oponentes. ${ }^{6}$ (LIPSET; ROKKAN, 1967, p.5)

Para os autores, a representação política que os partidos promovem é algo essencial para sua própria viabilidade. No entanto, este papel atribuído aos partidos de representar grupos e clivagens sociais não é igualmente percebido por outros autores. Na mesma linha de argumentação, de um comportamento evolutivo dos partidos políticos, Kirchheimer ([1966]/2012) descreveu o comportamento dos partidos catch all. Segundo o autor, os partidos catch all não estariam interessados em representar grupos específicos da sociedade e, portanto, passariam a adotar bandeiras cada vez mais difusas e genéricas de modo que pudessem conquistar ampla parcela do eleitorado sem se prender a nenhum grupo específico. Seu comportamento criaria vínculos mais fracos com suas bases eleitorais. Eles não teriam compromissos claros com grupos específicos e mudariam suas agendas de acordo com interesses próprios, ignorando os desejos de seus representados.

Katz e Mair (1995) não só reconhecem a contribuição dos autores anteriormente citados, como identificam um novo tipo de partido, que teria surgido na Europa em decorrência do afastamento dos partidos políticos de suas bases eleitorais: o partido cartel. Segundo os autores, os partidos políticos fazem um movimento de distanciamento de suas bases de apoio - ou de forma mais ampla, pode-se dizer que os partidos se afastam cada vez mais da sociedade - e voltam-se cada vez mais para o interior do Estado. Desta forma, como consequência do financiamento público de campanhas, os partidos não precisariam mais da própria sociedade para existir e, portanto, não teriam motivos para manter vínculos com seus representados.

Parte da literatura - entre os quais estão os clássicos discutidos anteriormente apresenta motivos para que seja questionada a existência de um vínculo entre cidadãos e partidos da forma como os estudos de Duverger e de Lipset e Rokkan descreveram. Mesmo antes destes clássicos, já havia críticas a esta visão de partidos como

\footnotetext{
${ }^{6}$ No original: "force the spokesmen for the many contrasting interest and outlooks to strike bargains, to stagger demands, and to aggregate pressures. Small parties may content themselves with expressive functions, but no party can hope to gain decisive influence on the affairs of a community without some willingness to cut across existing cleavages to establish common fronts with potential enemies and opponents".
} 
representantes de grupos ou classes específicas. Por exemplo, Schattschneider (1942), em seu estudo clássico afirma que:

Descrever o partido como se ele fosse esse tipo de associação de eleitores significa produzir confusão, e, ainda mais, tornar-se vítima de um veículo promocional tão antigo que não deveria enganar ninguém. $O$ conceito de partidos enquanto uma associação de massa de partidários não tem bases históricas e tem pouca relação com os fatos da organização partidária. Basta examinar as plataformas dos partidos, entretanto, para ver o quão persistentemente os partidos têm tentado se identificar com todos os eleitores que podem ter apoiado seus candidatos. ${ }^{7}$ (SCHATTSCHNEIDER, 1942, p.54)

Michels em 1915 escreveu em sua obra clássica que:

O partido, enquanto forma exterior, mecanismo, máquina, não se identifica necessariamente com o conjunto de membros inscritos e menos ainda com a classe. Tornando-se um fim em si mesmo, atribuindo-se objetivos e interesses próprios, ele pouco a pouco se separa da classe que representa. (MICHELS, 1982, p.241)

A referência a Michels e a Schattschneider busca auxiliar na orientação deste estudo para uma abordagem mais voltada para o comportamento dos partidos políticos, ao invés de focar-se em discussões sobre o surgimento de novos tipos de partidos políticos ou sobre o declínio dos partidos de massa. Vemos que, apesar de estudos clássicos terem ressaltado os vínculos entre os partidos e suas constituencies, os argumentos apresentados pelos autores que posteriormente explicaram a fragilização desta conexão com base no surgimento de um novo tipo de partido, já poderiam ter sido apresentados quando do surgimento dos partidos de massa. Logo, não há como concluir se foram os partidos ou as análises sobre eles que mudaram, dando ênfase a diferentes a características que sempre estiveram presentes.

\subsection{Partidos Políticos e Políticas Públicas}

A evidência de que os partidos políticos se diferenciam costuma ser tratada como prova de que os partidos políticos vocalizam os interesses de diferentes grupos sociais. Apesar

\footnotetext{
${ }^{7}$ No original: "To describe the party as if it were this sort of association of voters is to produce confusion, and, moreover, to be victimized by a promotional device so old that it should deceive no one. The concept of the parties as a mass association of partisans has no historical basis and has little relation to the facts of party organization. It is only necessary to examine the platforms of the parties, however, to see how persistently the parties have tried to identify themselves with all voters who may have supported their candidates".
} 
de nem sempre haver menção direta, a afinidade de muitos autores com as análises de Duverger e de Lipset e Rokkan são bem claras. Por exemplo, um dos autores mais citados desta literatura concluiu que

As políticas macroeconômicas seguidas pelos governos de esquerda e de direita estão em amplo acordo com os interesses econômicos objetivos e preferências subjetivas de suas bases eleitorais definidas por classe. ${ }^{8}$ (HIBBS, 1977, p.1468)

Ao analisar as preferências dos eleitores, divididos por renda e por grupos ocupacionais, e os padrões das políticas macroeconômicas e seus efeitos sobre o desemprego e a inflação (o trade off descrito pela curva de Phillips), Hibbs (1977) mostra que os interesses de diferentes grupos de eleitores são representados por partidos diferentes. Assim, defende que os partidos políticos produzem políticas distintas porque representam os interesses políticos de diferentes bases eleitorais.

Entretanto estudos com conclusões opostas implicam que a agenda de pesquisa sobre a influência dos partidos políticos sobre as políticas públicas seja inconclusiva. Levando em consideração fatores como educação, urbanização e desenvolvimento regional, os estudos de Hofferbert (1966), Fry e Winters (1970) e Winters (1976) concluem que os partidos políticos em pouco influenciam a implementação de políticas públicas.

Wilenski (1975), que segue esta mesma linha de argumentação, afirma que o gasto com seguridade social tem quatro quintos de sua variação explicada pela antiguidade dos sistemas de seguridade social e por seu desenvolvimento econômico, o que leva o autor a negar a importância dos partidos políticos.

Garrett e Lange (1991) pesquisaram as políticas macroeconômicas de países da OCDE e concluíram que teria ocorrido uma redução no espaço da ação partidária, ocasionada pela maior interdependência econômica das nações. Os Estados nacionais já não possuiriam autonomia para perseguir estratégias macroeconômicas independentes. Por vezes, seus governantes deveriam subordinar objetivos partidários às exigências da competição eleitoral. Mas ainda haveria espaço, na arena do governo, para a adoção de estratégias distintas, explicadas pelas siglas partidárias. Logo, não haveria uma

\footnotetext{
${ }^{8}$ No original: "the macroeconomic policies pursued by left and right-wing governments are broadly in accordance with the objective economic interests and subjective preferences of their class defined core political constituencies".
} 
neutralização das diferenças partidárias e uma convergência na direção de políticas neoliberais. Apenas mudariam as estratégias partidárias, que ainda continuariam consistentes com preferências programáticas.

Análises dos efeitos de partidos políticos sobre as políticas continuaram a receber atenção de importantes estudiosos, que tenderam a destacar a importância dos partidos políticos. Boix (1998), por exemplo, destaca que o crescimento da desigualdade tende a ser um reflexo das escolhas de governos conservadores em priorizar o crescimento econômico mediante o estímulo ao investimento privado. Esta agenda de pesquisa continua produtiva e autores influentes ainda afirmam que "enquanto fatores socioeconômicos podem explicar o quanto as sociedades gastam em provisões sociais, a política continua a chave para quem ganha o quê, quando e com qual efeito na arena do welfare" (CASTLES; OBINGER, 2007, p. 217) 9

Assim, o fato de esta agenda de pesquisa continuar tão ativa mostra que a influência dos partidos políticos sobre as escolhas dos governos não é uma questão encerrada na ciência política. Exemplo disto é o estudo de Imbeau et al (2001) que, apesar de não ser capaz de descartar a hipótese da convergência partidária, mostra mediante uma metaanálise a inflexão nos estudos sobre partidos políticos. As análises anteriores a 1973 coincidiam com o crescimento econômico elevado dos países da OCDE. Neste contexto, os conflitos partidários ocorreram basicamente em relação às despesas com welfare, sobre quais políticas seriam adotadas para redistribuir recursos abundantes. Porém, 0 período posterior a 1973 trouxe baixas taxas de crescimento, alta inflação e desemprego. $O$ resultado foi que o conflito entre a esquerda e a direita moveu-se para a questão relativa ao tamanho apropriado do setor público. A conclusão mais importante deste trabalho é que o contexto altera as expectativas plausíveis sobre o comportamento dos partidos políticos.

Dadas as divergências da literatura, os estudos que mais contribuem para esta agenda são aqueles que levam em consideração os contextos em que os partidos políticos atuam. Rose $(1984 ; 1990)$ argumenta que os partidos podem ter preferências programáticas, mas que também é preciso considerar que estes assumem governos sob

\footnotetext{
${ }^{9}$ No original: "while socioeconomic factors may explain how much societies ultimately spend on social provision, politics remains the key to who gets what, when and with what effect in the welfare arena".
} 
condições que não permitem que políticas sejam cortadas sem custos eleitorais graves. Logo, as políticas existentes constrangem e influenciam o universo de escolhas dos governantes tanto quanto as instituições (PIERSON, 2004). Portanto, o legado de políticas sobre as escolhas dos governos do dia implica que governos não contam com inteira liberdade de escolha. Antes de fazer suas escolhas, devem dar seguimento a compromissos herdados. Ainda assim, políticas herdadas hoje são frutos de decisões de governos passados (SCHMIDT, 1996). Desta forma, o legado também carrega efeitos partidários. Mas o legado de políticas é apenas um dos importantes constrangimentos que os partidos encontram quando governam. As decisões dos governos locais são resultantes, também, de interações entre diferentes níveis de governo e da influência que o sistema partidário tem sobre as decisões dos governantes.

\subsection{Política Partidária em Governos Subnacionais}

A influência da União sobre as políticas dos governos subnacionais pode ser fator determinante para constranger a influência dos partidos políticos. Em estudo sobre a influência dos partidos políticos sobre as políticas de assistência social, trabalhista e de educação nos Lander alemães, Turner (2011) mostra como na política de educação, a área de política menos regulamentada na federação alemã, a influência dos partidos políticos é mais clara. Levando em consideração a influência dos níveis superiores de governo, Saéz e Sinha (2010) argumentam em favor de ir além das análises agregadas de gastos e examinar variações nos gastos desagregados.

Assim como no Brasil, os governos locais nos E.U.A. têm capacidade limitada para produzir políticas. Levando isso em consideração, Gerber e Hopkins (2011) investigaram se os constrangimentos impostos pela União na federação norte americana minam a influência do partido do prefeito nas políticas implementadas. Os resultados encontrados pelos autores mostram que governos Republicanos estão associados com o aumento substantivo e estatisticamente significativo dos gastos orçamentários com polícia e com proteção contra incêndios, duas das poucas políticas em que a sobreposição entre autoridade federal, estadual e local é relativamente pequena. Desta 
forma, os autores concluem que as áreas menos regulamentadas pelo governo federal são aquelas em que há maior espaço para que os partidos exerçam influência.

A conclusão de Gerber e Hopkins é coerente com a literatura que, analisando o caso brasileiro, argumenta que os constrangimentos impostos pela União podem ser o motivo que impede a identificação de efeitos partidários nas políticas analisadas (RIBEIRO, 2005; RODRIGUES, 2007; SÁTYRO, 2008). Mas a comparação com os EUA não ajuda muito, pois um sistema partidário que é monopolizado por dois partidos na federação inteira não reflete bem as estratégias que um mesmo partido deve adotar quando compete com diversos rivais pela conquista do governo em diferentes localidades. Neste sentido, o trabalho de Greer (2005) parece dialogar melhor com o cenário brasileiro. Greer argumenta que o Partido Trabalhista na Escócia é opositor ao Partido Nacional Escocês, que está ideologicamente à sua esquerda, enquanto o Partido Trabalhista na Inglaterra se opõe ao Partido Conservador, que está ideologicamente à sua direita. A consequência disto é que o Partido Trabalhista na Escócia deve adotar políticas mais à sua esquerda enquanto o Partido Trabalhista na Inglaterra deve adotar políticas à sua direita. Isso ocorre porque o mesmo partido disputa batalhas eleitorais distintas e, para ganhá-las em contextos diversos, precisa adotar estratégias diferentes. Pensar nas opções que os partidos têm quando competem no nível local implica assumir que eles podem agir estrategicamente em relação às políticas adotadas. Um exemplo de comportamento estratégico da parte dos partidos políticos é elaborado por Persson e Svensson (1989). Os autores demonstram formalmente que, se um partido acredita que tem chances significativas de perder a eleição para seu rival, tenderá a imitar as políticas que seu rival implementaria se eleito. No entanto, nem todas as análises que consideram o comportamento estratégico dos atores concluem que haverá convergência. Segundo Krasa e Polborn (2010), se há dois partidos com habilidades diferentes para prover diferentes tipos de políticas e um orçamento que não aumenta de acordo com seus desejos de gastos, a melhor escolha que eles podem fazer é investir mais dinheiro nas políticas em que conseguem garantir melhores resultados, pois fazer o contrário significa investir dinheiro em políticas que não terão retornos tão bons e reduzir o gasto em políticas que permitem maior retorno eleitoral. 


\subsection{A Questão da Interação na Agenda de Estudos Brasileira}

Assumir que ao fazer suas escolhas os governos levam em consideração fatores demográficos, a relação com outros níveis de governo e a configuração do sistema partidário local pode enriquecer a agenda de estudos brasileira. Um exemplo do estado da arte é o trabalho de Rodrigues (2007), que simplesmente calcula a média dos gastos sociais dos prefeitos de um mesmo partido e compara-os com a média dos gastos dos prefeitos de outros partidos. Ele analisa apenas a execução dos gastos sociais dos prefeitos dos municípios de até 30 mil moradores ${ }^{10}$ do estado de Santa Catarina durante duas legislaturas para observar se a sigla partidária do prefeito pode ser classificada como um indicador de ideologia política e, consequentemente, se seus gastos em políticas sociais seguem algum padrão ideológico ou partidário. Os resultados encontrados por Rodrigues são todos negativos. Mas este tipo de procedimento ignora quaisquer constrangimentos que os prefeitos possam enfrentar e simplifica a análise de tal maneira que nenhum resultado encontrado desta forma pode ser considerado conclusivo.

Outro tipo de abordagem é a de Cavalcante (2011), que cria um índice de gasto social somando as despesas municipais em educação, saúde, assistência social e habitação e dividindo-as pelo total das despesas municipais. O problema deste tipo de análise é a criação de um indicador que mistura políticas diferentes que são afetadas por constrangimentos específicos (como educação e saúde), tratando-as como similares simplesmente porque ambas são políticas sociais. Além disto, questões de valência são tratadas superficialmente, pressupondo que partidos de direita diminuirão os gastos em políticas sociais e ignorando qualquer posicionamento público que os representantes dos partidos tenham feito sobre as políticas analisadas. Os problemas apresentados na pesquisa de Rodrigues (2007) e de Cavalcante (2011) são comuns na literatura com a qual este trabalho discute. A contribuição pretendida aqui é desenvolver uma análise que leva em consideração as melhores opções de ação que os prefeitos devem adotar caso tenham preferências sobre políticas ou caso busquem apenas ganhar a próxima eleição. Neste caso, devemos considerar o contexto em que estas decisões são tomadas.

\footnotetext{
10 O pressuposto do autor é que municípios com menos de 30 mil habitantes tendem a possuir um Executivo mais forte, evidência que fortaleceria seu argumento.
} 
Este trabalho assume que fatores demográficos, demandas populacionais, políticas federais, interações com os demais níveis de governo e a configuração do sistema partidário são os elementos mais importantes deste contexto.

Muitos estudos desta agenda têm grandes ambições e acabam abordando muitas políticas complexas ao mesmo tempo. Os resultados negativos deixam dúvidas se a metodologia utilizada foi a mais adequada, em particular se o exame de diversas políticas examinadas de modo agregado - como educação, saúde, assistência social não afetaria os resultados, posto que sua trajetória é afetada por fatores específicos. Por exemplo, os estudos de Rodrigues (2007) e de Sátyro (2008) tratam da política de educação, entre outras políticas sociais, mas nenhum deles dá atenção ao fato de que a demanda populacional pode ter efeito significativo sobre as decisões que os prefeitos e governadores tomam nestas áreas.

Sátyro (2008) observa os gastos em políticas sociais dos governadores do Distrito Federal e de todos os estados do Brasil de 1987 a 2006. Sua análise é mais bem sucedida que a anterior. Entretanto, a autora só encontra diferenças partidárias para o período anterior ao governo $\mathrm{FHC}$, o que lhe permite concluir que os constrangimentos impostos pelo governo FHC homogeneizaram os gastos sociais e eliminaram as distinções partidárias.

Quando consideramos os constrangimentos impostos pelas políticas federais à implementação das políticas, começamos a ter um retrato mais detalhado do espaço de manobra em que se movem os prefeitos. Por exemplo, como foi mostrado no capítulo anterior, a aprovação do FUNDEF significou o estabelecimento de que $15 \%$, dos $25 \%$ de receita que os municípios são constitucionalmente obrigados a gastar em educação, deveriam ser destinados ao ensino fundamental (ARRETCHE, 2002). Assim, a gestão dos recursos em educação tendeu a uma homogeneização dos gastos (ARRETCHE, 2010). A exemplo disto, Menezes-Filho e Pazello (2004) demonstram como o remanejamento orçamentário causado pelo FUNDEF foi responsável pela elevação da média salarial dos professores de ensino fundamental -, mesmo em municípios que perderam receitas. 


\subsection{Conclusão}

É possível observar o comportamento dos partidos políticos com base em muitas teorias diferentes. Entretanto, teorias clássicas sobre os partidos políticos não necessariamente ajudam na análise de suas escolhas sobre políticas públicas. Ainda que as teorias clássicas sustentem que os partidos políticos terão preferências distintas, pois estão associados a constituencies diferentes, visões que já existiam quando estas teorias surgiram mostram como, desde o surgimento, elas já seriam contestáveis em muitos de seus pontos considerados centrais. Por esta razão, testar empiricamente a influência dos partidos políticos sobre as políticas públicas permanece uma questão em aberto na ciência política.

Entretanto, este trabalho argumenta que esta relação não pode ser examinada ignorando o contexto em que governos tomam decisões. A influência das políticas federais (ARRETCHE, 2009), a influência que o governo estadual pode exercer sobre as políticas locais de educação (ARRETCHE, 2000; GOMES, 2009) bem como a competição com outros partidos políticas e preferências ideológicas afetam as escolhas dos governos (KRASA; POLBORN, 2010; WHITTEN; WILLIAMS, 2011). Estes são subsídios para analisar como os partidos políticos que têm preferências sobre políticas públicas se comportam quando comparados com aqueles sem preferências.

É importante notar que, para saber se partidos importam, é necessário que haja oposição de preferências entre eles. Se apenas um partido adotar uma política e o outro apenas der continuidade a esta política, estudos que não considerem a ação estratégica dos partidos políticos podem chegar à conclusão que os partidos não importam, quando na verdade um deles implementa uma agenda e o outro apenas age com indiferença, preservando o status quo. Tal conclusão seria similar à de Rose (1990), que afirma que o legado é mais forte que os partidos, mas esquece que as políticas herdadas só foram implementadas devido às decisões tomadas por um partido político no início da trajetória (SCHMIDT, 1996). Por isso, uma análise que contribua para o atual estado da arte nesta agenda deve levar em consideração o interesse (ou não) dos partidos promoverem determinadas políticas, a influência da demografia, os constrangimentos enfrentados pelos partidos na implementação de suas políticas e a configuração do sistema partidário. No capítulo seguinte é apresentado um modelo teórico que 
pretende contribuir para a análise empírica da relação entre partidos incumbentes e suas escolhas que leva rigorosamente em consideração os elementos do contexto. 


\section{CAPÍTULO 3: UM MODELO FORMAL DE INFLUÊNCIA PARTIDÁRIA}

"Essentially, all models are wrong, but some are useful" (George Box e Norman Draper)

O objetivo deste capítulo é, com base na discussão apresentada nos capítulos anteriores, desenvolver um modelo formal para a análise da influência partidária sobre as políticas públicas. Mais pontualmente, o modelo será utilizado para analisar a influência partidária sobre a política de educação nos municípios brasileiros. Entretanto, ele foi elaborado de modo a ser simultaneamente amplo o suficiente para ser aplicado à análise de outras políticas e de outros níveis de governo e restrito o suficiente para que não se torne inútil. O objetivo do modelo é tornar explícitos os pressupostos da análise e articular o conteúdo dos dois capítulos anteriores à análise empírica e a interpretação dos resultados desenvolvida nos próximos capítulos.

Os estudos que utilizam modelos formais para estimar o comportamento dos partidos tendem a pressupor partidos que se comportam de maneira semelhante, como se houvesse apenas um tipo de partido. Esta simplificação é conseqüência do trabalho de Downs (1957) ser uma das principais referências desta literatura.

Downs (1957) foi um dos primeiros autores a pensar como seria o comportamento racional e estratégico dos partidos políticos. Seu objetivo era contribuir com a teoria econômica, que descreve o comportamento de indivíduos egoístas interagindo no mercado, mediante a elaboração teórica de um ator governamental que não seria neutro no desempenho de seu papel. A teoria de Downs supõe impulsos egoístas e descreve a competição política entre indivíduos tão egoístas quanto aqueles que eles buscam governar. Há muitas críticas à sua teoria, mas sua contribuição é clara: é possível olhar para o governo e analisá-lo em termos de comportamento estratégico entre indivíduos que possuem objetivos próprios.

A proposta deste modelo é comparar o comportamento de dois tipos de partidos enquanto eles se alternam no governo. Estes partidos podem ser classificados como policy seekers e office seekers. Diferentemente do modelo downsiano, que analisa os 
partidos tomando decisões simultâneas sobre o lugar que devem ocupar no contínuo esquerda-direita, aqui é considerado que os partidos tomam suas decisões sobre políticas em momentos distintos. O motivo desta escolha é que, uma vez que as políticas são nosso indicador de preferência partidária, é necessário considerar a situação que o partido encontra quando assume o governo, para só então examinar como o governante pode modificá-la. Mudanças nas políticas realizadas por um partido no governo são sempre relativas às políticas que este herdou. Esta abordagem permite que contextos diferentes sejam levados em consideração.

Para discorrer sobre as opções de ação que os partidos têm no que diz respeito às políticas que implementam, é necessário deixar explícito o que o total de políticas públicas de um governo significa. A equação (3.1), retirada de Rose (1990), expressa formalmente o total de políticas públicas existentes em um governo:

$$
T P P_{t n}=S P H_{t n-x}+\Delta P H+N P
$$

Onde TPP equivale ao total de políticas públicas, $t n$ expressa o tempo $n, S P H$ é a soma de todas as políticas herdadas pelo governo, $\Delta P H$ é a variação nas políticas herdadas que o governo atual realizou e $N P$ são as novas políticas implementadas pelo governo atual. Como o governo do dia não escolhe as políticas que herda, suas ações se limitam ao segundo e ao terceiro termo do lado direito da equação (3.1). Entretanto, podemos incluir a criação de novas políticas à alteração do legado sem prejuízo da análise, de modo que temos:

$$
A=\Delta P H
$$

Onde $A$ representa as ações que o governo toma em relação às políticas públicas. Cabe agora investigar qual o comportamento ótimo para cada tipo de partido em cada um dos cenários possíveis. $\mathrm{O}$ argumento básico da literatura com a qual se discute aqui é que, se os partidos importam, eles vão diminuir ou encerrar as políticas que são contrárias à sua ideologia ou, alternativamente, vão implementar novas políticas ${ }^{11}$. As análises que investigam este fenômeno com um grande número de casos esperam que

\footnotetext{
11 Estas premissas são seriamente influenciadas por estudos focados em políticas fiscais e macroeconômicas e por estudos sobre o welfare state. Exemplos destas abordagens podem ser encontrados em Boix (1998), Obinger, Liebfried e Castles (2005) e Wilenski (1975).
} 
este comportamento seja repetido sistematicamente. No entanto, quando levamos a análise para o plano local, em um sistema multipartidário, os partidos que lideram a competição política nos municípios podem não ser os mesmos que a comandam no governo central. Desta forma, podemos ter partidos com preferências claras sobre políticas competindo com partidos que são apenas office seekers. Isto não implica que partidos com preferências sobre políticas em determinada área tenham preferências claras sobre políticas em quaisquer outras áreas. Assim, "um partido pode se comportar como um ator unitário em uma dimensão política, mas ser esquizofrênico em outra"12 (LAVER; SCHOFIELD, 1998, p. 33). Ou seja, definir os partidos políticos como direita e esquerda e daí derivar suas preferências sobre políticas pode ser uma estratégia de pesquisa pouco produtiva para investigar seu comportamento. Por isto, apesar de esta análise ser dividida entre dois tipos de partido, é necessário deixar claro que um partido com preferências sobre políticas pode ser um partido ideologicamente de esquerda ou de direita. É importante o posicionamento do partido sobre a política em questão e como partidos com e sem preferências interagem com o legado de políticas que herdam.

\subsection{Pressupostos Teóricos}

Antes de analisar o comportamento esperado dos diferentes tipos de partidos, é preciso deixar claros alguns pressupostos do modelo proposto. Eles simplificam o modelo e reduzem o número de variáveis às características essenciais ao cálculo estratégico dos atores. Os pressupostos do modelo são:

- Considera-se apenas o comportamento partidário no Poder Executivo.

O ocupante do cargo de chefe do Poder Executivo tem poder para implementar políticas e, apesar de ter que negociar com o Poder Legislativo para implementar suas políticas, é considerado forte o suficiente para direcionar a agenda do Legislativo no sentido desejado. Os custos destas negociações podem ser considerados como parte do esforço que os governantes devem fazer para alterar o legado de políticas herdado.

\footnotetext{
${ }^{12}$ No original "A party may behave as a unitary actor on one policy dimension, but be schizophrenic on another".
} 
- Os atores ideológicos não enfrentam problemas de coordenação.

Este pressuposto afirma que os governantes que têm preferências sobre políticas e pertencem a um mesmo partido também têm visão comum sobre objetivos e que todos desejam da mesma maneira alcançar tais objetivos. Desta forma, se referir ao prefeito de um partido ideológico atuando no governo local é o mesmo que se referir ao próprio partido no mesmo local.

- As preferências dos partidos sobre determinadas políticas estão em um contínuo.

As preferências não são multidimensionais. Os partidos ideológicos simplesmente desejam mais ou menos em determinada política. Assim, todas as questões podem ser consideradas em um contínuo. Tornar as preferências multidimensionais complicaria o problema aqui descrito sem necessariamente trazer ganho substantivo aos resultados apresentados.

- A única forma de o governo aumentar suas intenções de votos é mediante a produção de políticas.

Investimentos em campanhas eleitorais ou em outras formas de obter votos são ineficazes. O governante que desejar obter mais votos deverá necessariamente alterar o legado de políticas que herdou e implementar novas políticas. Considerar campanhas eleitorais desviaria o foco da análise para as interações entre o incumbent e o eleitorado, enquanto que a análise aqui apresentada é voltada para o incumbent e o legado de políticas herdadas.

Tendo apresentado estes quatro pressupostos a seguir é discutido o comportamento estratégico dos partidos políticos.

\subsection{O Modelo Formal}

Primeiramente será considerado o comportamento esperado de um governante pertencente a um partido office seeker, $\boldsymbol{O}$. Como o governante $\boldsymbol{O}$ retira benefícios de ocupar o gabinete, mas não se beneficia de implementar políticas além do mínimo 
necessário para garantir sua reeleição, em um cenário sem constrangimentos, sua função de utilidade é definida por:

$$
E(U)_{O}=u p_{O}+r e_{O}-e f_{O}
$$

Onde up é o uso pessoal que o governante $\boldsymbol{O}$ faz de seu cargo para ganhar benefícios para si mesmo, re indica a utilidade que ele retira de ganhar a próxima eleição e ef o esforço que ele faz para conseguir ganhar a próxima eleição implementando novas políticas e modificando políticas herdadas. Portanto, o cenário ideal para o governante $\boldsymbol{O}$ é aquele em que ele consegue maximizar seus benefícios presentes e suas chances de ganhar a próxima eleição e minimizar as alterações que promove no legado de políticas que herda.

Entretanto, este cenário não leva em consideração que o governo local possa enfrentar constrangimentos impostos pelo governo central. No modelo aqui proposto, as intervenções do governo central restringem as ações dos governantes, descritas na equação (3.2), exatamente para impedir que os governantes reduzam ao mínimo o esforço que fazem. $\gamma$ representa o mínimo de alterações que o governo central induz os governos subnacionais a realizar, ou o mínimo de esforço que o governo central força os governantes locais a colocar em suas políticas. O ponto central é que os governantes que não têm preferências partidárias, acreditando que possuem boas chances de reeleição, farão com que as mudanças implementadas sobre o legado que eles herdaram convirjam para $\gamma$ de modo que a equação (3.2) do governante $\boldsymbol{O}$ tenderá a (3.4):

$$
A_{O}=\gamma
$$

Ou seja, em uma situação favorável à sua reeleição, o governante $\boldsymbol{O}$ fará o mínimo a que for constitucionalmente obrigado de alterações em seu legado de políticas.

O passo seguinte é levar em consideração a estratégia ótima do governante de um partido policy seeker, $\boldsymbol{P}$. O que distingue $\boldsymbol{P}$ é ele possuir preferências sobre políticas que se justificam ideologicamente. Ao implementar suas políticas preferidas, o governante $\boldsymbol{P}$ também recebe ganhos positivos de utilidade que são referentes a promover mudanças nas políticas, deixando-as mais próximas de suas preferências ideológicas, $I_{P}$. É este ganho ideológico que faz com que ele considere que alterar políticas herdadas 
possa valer a pena mesmo acreditando que sua reeleição já esteja garantida. Ainda assim, este tipo de ator também retira benefícios pessoais de ocupar seu cargo e também busca a reeleição.

Para implementar suas políticas preferidas, o governante $\boldsymbol{P}$ deverá modificar o legado de políticas que herdou em relação àquele que ele deixará para seu sucessor. Assim suas políticas preferidas, $P P_{P}$, podem ser formalizadas como segue em (3.5):

$$
P P_{P}=I_{P}-e f_{P}
$$

Ou seja, as políticas preferidas de $\boldsymbol{P}, P P_{P}$, equivalem ao seu ganho em ideologia menos o esforço que é necessário para implementá-las. Uma condição necessária para que P continue implementando novas políticas é que:

$$
I_{P}>e f_{P}
$$

Desta forma, o governante $\boldsymbol{P}$ continuará implementando alterações em seu legado herdado até que os dois termos de (3.6) se igualem. Aceitar a equação (3.5) implica aceitar que a ideologia deste ator pode ser representada como a soma entre suas políticas desejadas e o esforço que ele está disposto a realizar para implementar tais políticas:

$$
I_{P}=P P_{P}+e f_{P}
$$

O ganho que a ideologia proporciona ao governante $\boldsymbol{P}$ é relativo ao quão distante de suas preferências sobre políticas está o legado de políticas que ele herdou. Assim, a utilidade recebida pela ideologia do governante $\boldsymbol{P}$ é um produto da interação entre a ideologia, $I$, e sua distância, $\theta$, em relação ao legado de políticas. $\theta$ está contido dentro do intervalo $0 \leq \theta \leq 1$ e expressa os retornos marginais decrescentes que a ideologia dá ao Governante $\boldsymbol{P}$ conforme este reduz a distância entre as políticas herdadas e suas preferências ideológicas. Ao decompor a ideologia e ao considerar seu efeito interativo com a distância em relação ao legado herdado, a função de utilidade do governante $\boldsymbol{P}$ pode ser descrita como:

$$
E(U)_{P}=\theta(P P+e f)_{P}+u p_{P}+r e_{P}-e f_{P}
$$

Isso significa que quando $\theta$ é igualado a zero, o esforço que o governante $\boldsymbol{P}$ faz para implementar uma política compatível com sua preferência ideológica se anula com o 
esforço que ele faz para alterar o legado de políticas herdado. Assim, quando $\theta$ se iguala a zero, a equação (3.8) torna-se a equação (3.3) e o governante $\boldsymbol{P}$ passa a agir como o governante $\boldsymbol{O}$.

Quando a distância entre o cenário ideal desejado pelo governante $\boldsymbol{P}$ tende a zero, seu comportamento se iguala ao comportamento do governante do partido $\boldsymbol{O}$. Entretanto, destaca-se que a ideologia de $\boldsymbol{P}, I_{P}$, terá efeitos sobre suas ações e políticas implementadas e este efeito será maior quanto maior for $\theta$, a distância do legado de políticas por ele herdado em relação às suas preferências ideológicas.

O passo seguinte é considerar quais são os possíveis resultados conforme os dois tipos de governantes se alternam no poder.

Cenário 1: $\boldsymbol{O}$ partido $\boldsymbol{P}$ assume o governo após saída do partido $\boldsymbol{O}$.

Figura 3.1: Partido P Assume o Governo após Saída do Partido $O$

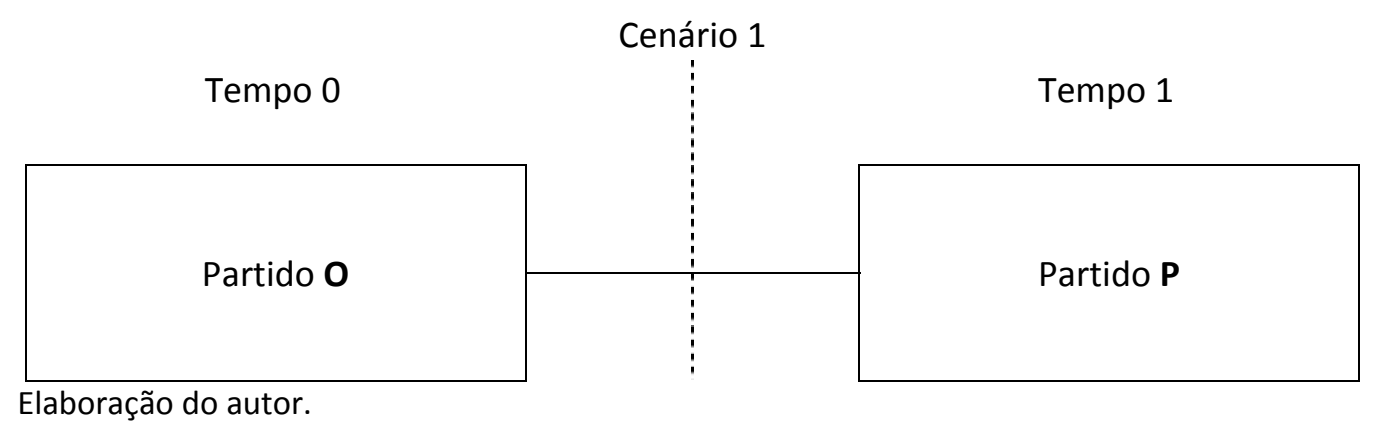

Neste cenário, o quanto as políticas implementadas por $\boldsymbol{P}$ vão se diferenciar das políticas de seu antecessor depende basicamente das restrições impostas pelo governo central, $\gamma$. Ou seja, quanto mais elevadas forem as restrições impostas aos governos subnacionais pelo governo central, menor é o campo de ação de $\boldsymbol{P}$, reduzindo-se o efeito de $\theta$ a um valor próximo de zero quando as preferências de $\boldsymbol{P}$ convergem para $\gamma$, ou elevando-se o ef necessário para diminuir $\theta$, quando as preferências de $\boldsymbol{P}$ são contrárias a $\gamma$. Caso não haja restrições à ação dos governos subnacionais e haja preferências sobre políticas, a distinção entre $\boldsymbol{P}$ e $\boldsymbol{O}$ será perceptível de forma sistemática.

Exemplo de posicionamento espacial dos partidos em relação a uma determinada política no cenário 1 quando $\gamma=0$ é exibido na figura a seguir: 
Figura 3.2: Posicionamento Relativo do Partido $O$ e do Partido P no Cenário 1 e no Cenário 2

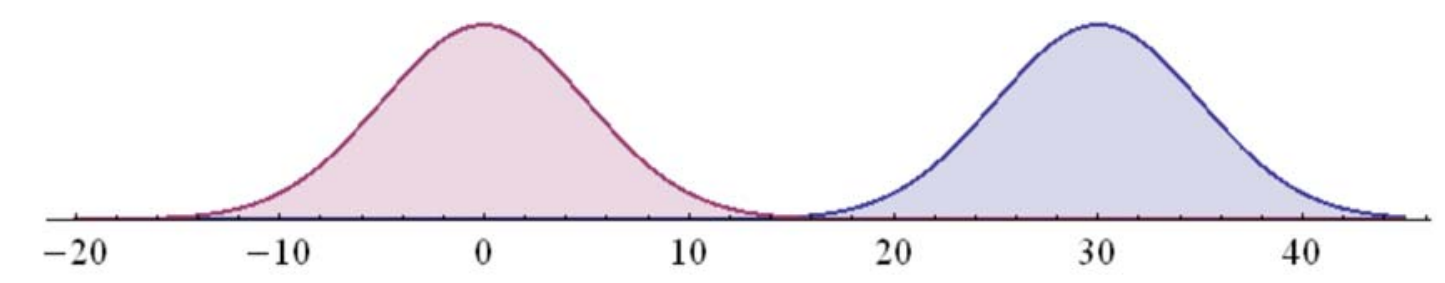

Elaboração do autor.

Cenário 2: $\boldsymbol{O}$ partido $\boldsymbol{O}$ assume o governo após saída do partido $\boldsymbol{P}$.

Figura 3.3: Partido O Assume o Governo após Saída do Partido P

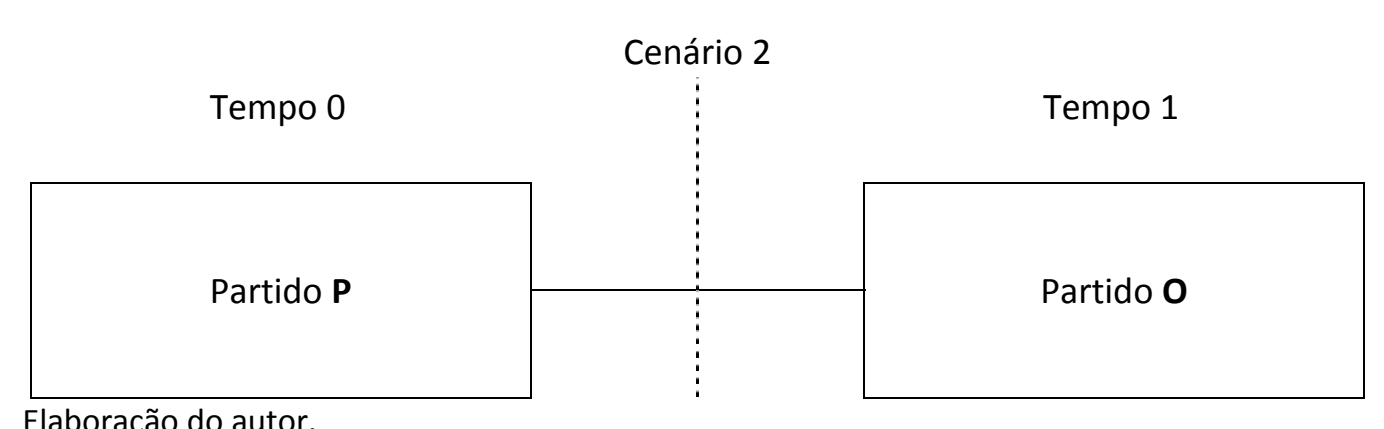

Elaboração do autor.

O legado de políticas, SPH,e os constrangimentos impostos pelo governo central, $\gamma$, são os fatores mais importantes para entender as políticas neste cenário. $\mathbf{O}$ partido $\boldsymbol{O}$ não ganha benefícios em cancelar as políticas que foram implementadas por $\boldsymbol{P}$. Deste modo, os únicos fatores capazes de fazê-lo implementar novas políticas é ter chances abaixo de $50 \%$ de vencer a próxima eleição ou estar diante de constrangimentos impostos pelo governo central que o obriguem a alterar o legado de políticas. É importante notar que, por não ganhar nenhum benefício acabando com políticas implementadas por $\boldsymbol{P}, 0$ governante $\boldsymbol{O}$ dificilmente interromperá políticas iniciadas por seu antecessor. Isso significa que, apesar de $\boldsymbol{P}$ e $\boldsymbol{O}$ claramente agirem de forma diferente, as análises que não levem em consideração as variações geradas pelos governos e o comportamento estratégico de $\boldsymbol{O}$ podem concluir que eles não se distinguem entre si. A figura abaixo mantém constante o posicionamento de $\boldsymbol{P}$ em relação à figura 3.1 e mostra como 0 comportamento de $\boldsymbol{O}$ poderia gerar interpretação equivocada de seu posicionamento espacial: 
Figura 3.4: Erro de Interpretação do Cenário 2

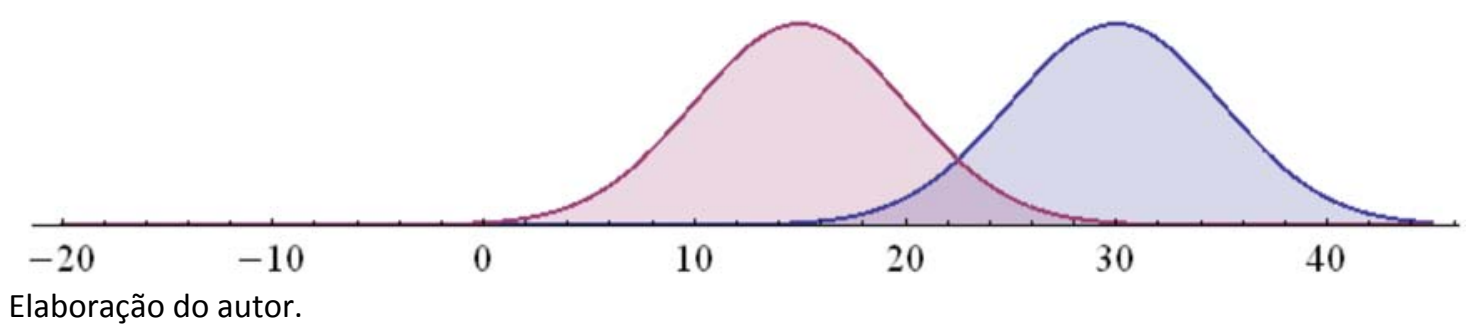

O tratamento indistinto do cenário 1 e 2 pode fazer parecer que o partido $\boldsymbol{O}$ está mais próximo de $\boldsymbol{P}$ em relação à implementação de políticas do que ele realmente está. Enquanto a Figura 3.2 reflete o posicionamento dos dois tipos de partidos, a Figura 3.4 mostra um possível erro de interpretação quando escolhas estratégicas não são consideradas.

Cenário 3: $O$ partido $O$ assume seu segundo mandato consecutivo.

Figura 3.5: Partido O Assume seu Segundo Mandato Consecutivo

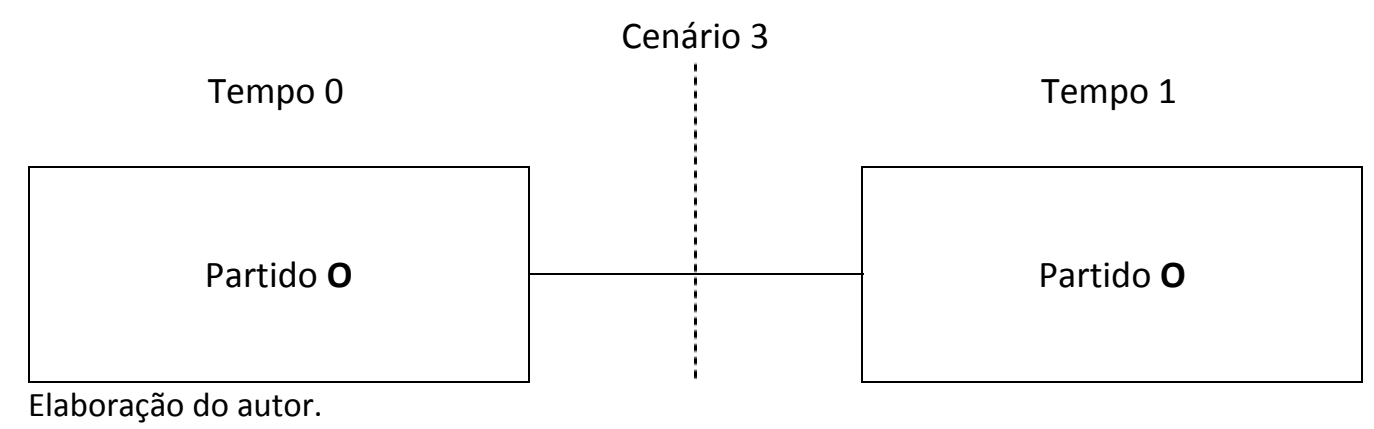

Aqui não ocorre mudança entre tipos de partidos no comando do governo. 0 governante $\boldsymbol{O}$ continua no governo e apenas chances declinantes de ganhar a próxima eleição ou constrangimentos impostos pelo governo central são capazes de fazê-lo alterar seu legado de políticas. De uma forma ou de outra, o ritmo de implementação de políticas tende a ser inercial neste cenário. Não havendo constrangimentos impostos por camadas superiores de governo, este é o cenário mais estático entre os analisados neste trabalho, pois só serão implementadas as mudanças no legado de políticas que forem necessárias para tornar positivas as chances de vitória do prefeito $\boldsymbol{O}$. É fácil perceber que os Estados que constrangem os governos subnacionais a adotar certas 
políticas consideram indesejada a possibilidade de que este cenário ocorra. A indução do governo central faz com que as alterações, consideradas as mínimas necessárias, ocorram independentemente do tipo de prefeito no comando do governo local. A figura abaixo mostra o comportamento esperado dos partidos quando se assume que fatores ideológicos não influenciam a implementação de políticas, não há constrangimentos que obriguem os partidos a implementarem políticas e ocorre convergência entre os partidos em direção ao centro:

Figura 3.6: Competição Política e Convergência entre Dois Partidos $O$

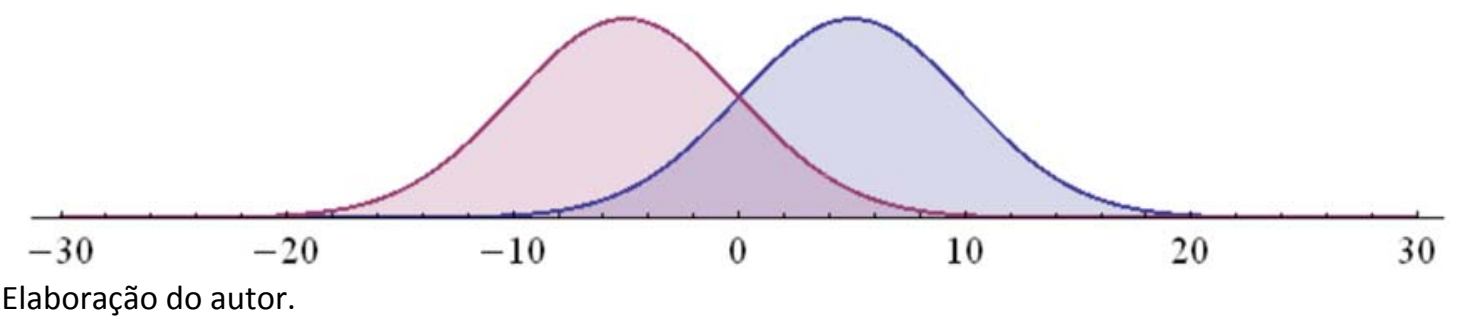

Cenário 4: $O$ partido $\boldsymbol{P}$ assume seu segundo mandato consecutivo.

Figura 3.7: Partido P Assume seu Segundo Mandato Consecutivo

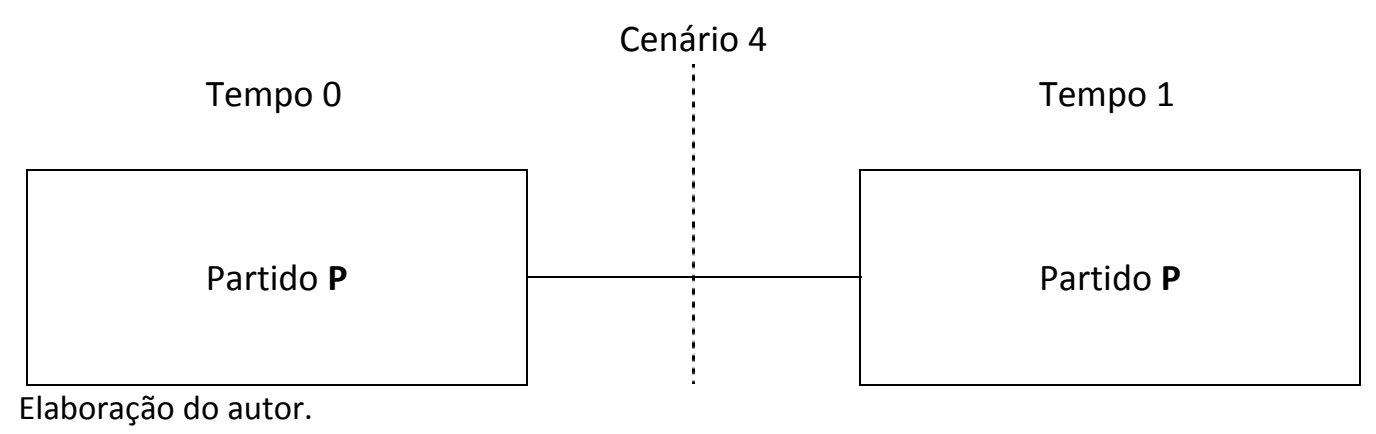

Assim como no cenário anterior, neste cenário não ocorre alteração do partido no governo. Observado $\theta(\mathrm{I})>\gamma+e f$, o prefeito $\boldsymbol{P}$ dá continuidade às alterações ocorridas no mandato anterior, mas como neste mandato o legado de políticas dele já se encontra mais próximo de seu ponto ideal $\left(\theta^{\prime}<\theta\right)$, tudo mais mantido constante, $\boldsymbol{P}$ implementa alterações em velocidade menor do que anteriormente. Caso $\theta(\mathrm{I})<\gamma+e f$, a variação gerada no legado de políticas por $\boldsymbol{P}$ não se distingue da mudança gerada por $\boldsymbol{O}$. 
Cenário 5: $\boldsymbol{O}$ partido $\boldsymbol{P}$ assume o governo após a saída de partido $\boldsymbol{P}$ com preferências opostas às suas.

Figura 3.8: Partido P Assume o Governo após Saída de Partido P com Preferências Opostas às suas

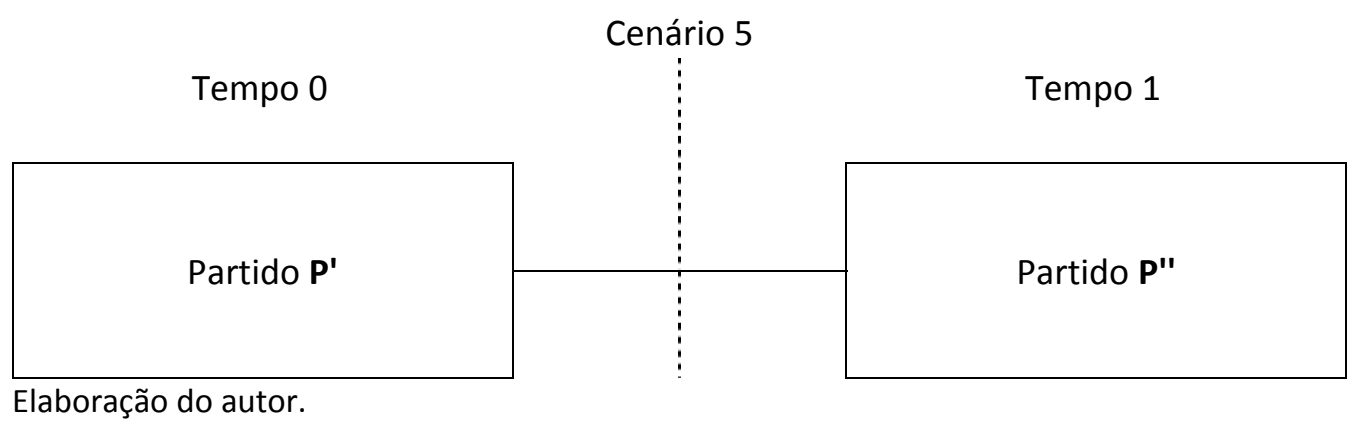

Este é o cenário clássico procurado pela maioria dos estudos de política comparada (ALT, 2010; BOIX, 1998; CASTLES; OBINGER, 2007; ESPING-ANDERSEN, 1991). Neste cenário, quando um partido assume o governo, ao reduzir seu $\theta$, ele necessariamente eleva o $\theta$ de seu opositor. Assim, sempre que se alternam no poder, tudo mais mantido constante, os partidos divergem entre si com muita clareza. Ainda assim, constrangimentos como $\gamma$ podem dificultar a identificação de tais divergências ao estabelecerem, indiretamente, um limite superior ou inferior para $\theta$. A figura 3.9 mostra o cenário que é majoritariamente esperado pelos estudos que analisam a influência partidária sobre as políticas públicas em um contexto em que constrangimentos externos às escolhas dos governos têm pouco peso:

Figura 3.9: Cenário Procurado pela Mainstream dos Estudos sobre Influência Partidária

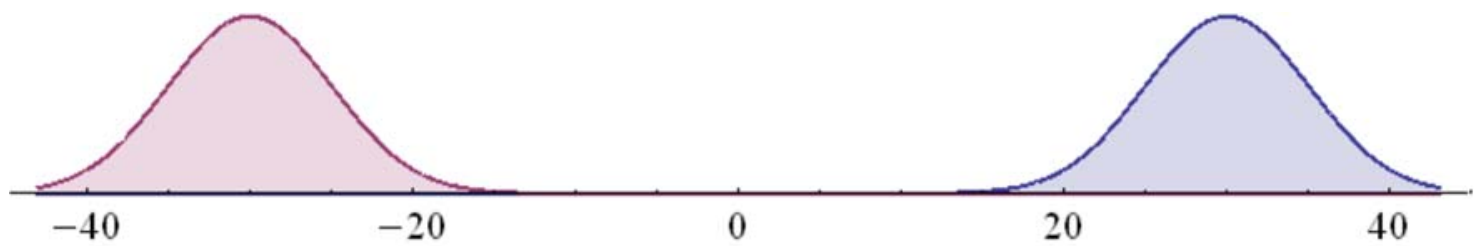

Elaboração do autor.

É importante notar que quando as análises não levam rigorosamente em consideração que estamos analisando o cenário 5, a tendência é assumir que os partidos não influenciam as políticas públicas. Desta forma, a hipótese nula tende a inferir que a situação existente é a da figura 3.6, retratando o cenário 3. No entanto, os cenários 1 e 2, que são tão possíveis de ocorrer quanto os demais, não costumam ser levados em 
consideração. Embora numerosos estudos reconheçam que constrangimentos externos possam fazer com que os partidos tendam a se comportar como na figura 3.4 (ALT, 2010; SAÉZ; SINHA, 2010), no momento de produção deste trabalho não se tem conhecimento de outro trabalho que tenha levado em consideração estes cinco contextos possíveis na implementação de políticas públicas.

Considerados os cinco cenários anteriores, é preciso ressaltar que a possibilidade de sua ocorrência varia de acordo com o sistema partidário e com a política em questão. Se considerarmos, por exemplo, políticas que tratam de questões de valência (STOKES, 1963), é muito pouco provável que o cenário 5 seja observado, pois um partido cujas preferências sobre políticas contrariem as preferências da maioria do eleitorado será punido eleitoralmente ao implementar suas políticas preferidas. Neste caso, o governante pertencente ao partido com preferências impopulares agiria como um governante $\boldsymbol{O}$ e reproduziria o comportamento previsto no cenário 2, ao invés de agir como previsto no cenário 5 .

Um ponto importante para traduzir estes cenários hipotéticos para análises empíricas é pensar quais seriam os resultados observados se estes cenários existissem e fossem estudados ignorando o comportamento estratégico dos governantes. Se os cenários 1 e 2 ocorrerem alternadamente em diferentes localidades, não importa a ordem em si, o que teremos é que análises de séries temporais sem os devidos controles poderão concluir que os partidos não se distinguem, apesar de só o prefeito $\boldsymbol{P}$ agir e implementar políticas ideologicamente coerentes. Isso ocorrerá porque, mesmo não estando no governo, o prefeito $\boldsymbol{P}$ direcionará as políticas da forma como preferir e, quando ele estiver fora do governo, o prefeito $\boldsymbol{O}$ dará continuidade a tais políticas. As análises de Rose $(1984 ; 1990)$ tendem a seguir este caminho.

Os cenários 3 e 4 são distintos, mas suas diferenças podem ser amenizadas caso os constrangimentos impostos pelo governo central aos governos subnacionais sejam fortes o bastante a ponto de deixar próxima de zero a distância entre o ponto ideal do prefeito $\boldsymbol{P}$ e as variações nas políticas oriundas da inércia do governo local; ou a ponto de elevar consideravelmente os custos de divergir das políticas induzidas pelo governo central. 
Este modelo formal pode ser muito útil para um melhor entendimento da política local no Brasil. A federação brasileira adotou um modelo que concentra policy decisionmaking na União, deixando aos governos locais basicamente decisões referentes ao policy-making (ARRETCHE, 2009, 2010). Isso significa que grande parte das decisões sobre políticas implementadas na área da educação no nível local são afetadas pela legislação federal ao passo que os governos locais decidem mais sobre detalhes referentes à execução de políticas do que sobre seu desenho. Ou seja, apesar de haver variação entre as políticas, é possível afirmar que no Brasil o $\gamma$ é razoavelmente elevado na educação. A isso se soma o fato de que o sistema partidário é composto, atualmente, por 32 partidos políticos ${ }^{13}$.

Limongi e Cortez (2010) mostraram como as alianças feitas pelos partidos para concorrer à presidência e ao cargo de governador nos estados brasileiros se estruturaram em torno do PT e do PSDB, dois dos principais partidos neste sistema político. Se for considerado que estes partidos se opõem por terem preferências programáticas distintas e, também, for considerado que o PMDB tende a apoiar 0 partido que estiver no controle da presidência no nível federal e a fazer alianças com o partido mais forte nos governos subnacionais, apenas estes três partidos já são suficientes para justificar a adoção do modelo aqui proposto.

$\mathrm{Na}$ análise da implementação de políticas sociais nos governos subnacionais brasileiros, lida-se com questões de valência e, portanto, os cenários 1, 2, 3 e 4 são possíveis de ocorrer. Ainda assim é um problema comum da literatura não dar a devida atenção ao uso estratégico que os governantes podem fazer das políticas para ganhar votos ou a pressupor que os partidos de direita simplesmente reduzirão as políticas sociais, o que no caso de questões de valência certamente leva a resultados subótimos para tais atores. Como Laver e Schofield (1998) afirmam

A descrição das funções inclui uma obrigação de, ao menos, fingir governar o país. Isto significa que um político guiado apenas pela mais pura das motivações de office-seeking deve camuflá-la, até certo ponto, mesmo após

\footnotetext{
${ }^{13}$ Fonte: http://www.tse.jus.br/partidos/partidos-politicos. Acessado em 22/06/2014.
} 
ter obtido sucesso na conquista do gabinete..$^{14}$ (LAVER; SCHOFIELD, 1998, p.38)

Análises mais atentas ao comportamento estratégico dos partidos devem levar em consideração suas preferências declaradas sobre políticas ${ }^{15}$. Sem controlar as preferências declaradas dos partidos, não há como saber onde os governantes/membros de partidos querem chegar, como eles são influenciados pelas políticas que herdam e que influência os partidos exercem sobre as políticas adotadas. Esta questão fundamental tende a ser ignorada pela maioria dos estudos sobre os governos subnacionais brasileiros. Como exemplo, é possível citar o caso do PT e do PSDB no que concerne à política de educação: o PT apresenta um discurso de que esta política deve ser voltada ao atendimento da demanda populacional, enquanto que 0 PSDB defende a priorização do ensino fundamental. No governo federal, as diferentes posições se materializaram em diferentes políticas. Assim, o PSDB criou um Fundo voltado para o ensino fundamental (FUNDEF) e o PT o substituiu por um Fundo voltado para toda a educação básica (FUNDEB).

\subsection{Conclusão}

Este capítulo mostrou que o comportamento dos partidos políticos, no que diz respeito à implementação de políticas públicas, pode ser melhor observado se levarmos rigorosamente a sério que governantes agem estrategicamente levando em consideração elementos do contexto em que operam, para além de suas preferências sobre políticas públicas. Cinco cenários de estratégia do governo local são hipoteticamente possíveis para entender melhor quais fatores podem intervir na relação entre partidos políticos e implementação de políticas.

\footnotetext{
${ }^{14}$ No original "The job description includes an obligation to pretend, at least, to run the country. This means that a politician driven only by the purest of office-seeking motivations must to a certain extent camouflage these, even after having succeeded in getting into office".

${ }^{15}$ São comuns críticas às formas de inferir as preferências dos atores políticos. Programas partidários podem ser interpretados apenas como propagandas e os discursos/entrevistas podem ser interpretados apenas como declarações, oportunísticas ou estratégicas, que se referem a contextos específicos. Entretanto, estas ferramentas permitem observar distinções partidárias e levantar hipóteses para futuros passos de pesquisas. Estas ferramentas possuem problemas, mas trazem contribuições importantes. Elas não devem ser descartadas porque possuem problemas. Elas devem ser utilizadas levando em consideração quais são suas limitações.
} 
No próximo capítulo, a metodologia utilizada neste trabalho é apresentada e discorrese sobre as variáveis empregadas para incluir controles essenciais para a análise empírica deste trabalho. 


\title{
CAPÍTULO 4: METODOLOGIA, DADOS E HIPÓTESES
}

\author{
"Experience with real-world data, however, soon convinces one that both \\ stationarity and Gaussianity are fairy tales invented for the amusement of \\ undergraduates"
}

(David Thomson)

Este capítulo apresenta a metodologia utilizada nesta pesquisa assim como os dados empregados e as principais hipóteses a serem testadas no capítulo 5. Ele está dividido em quatro seções. A primeira seção apresenta os dados usados nas análises empíricas e discorre sobre a construção das variáveis dependentes. A segunda seção discute a metodologia utilizada e apresenta os modelos de regressão a serem utilizados no capítulo 5. A terceira seção apresenta as preferências do PMDB, do PSDB e do PT sobre a educação tal como explicitados na arena federal. Esta seção também discorre sobre a influência que governadores podem ter sobre as políticas implementadas pelos prefeitos. A quarta seção apresenta as hipóteses de trabalho que serão testadas no capítulo cinco.

\subsection{Dados}

Os dados utilizados nesta pesquisa cobrem o período de 2000 a 2012. A criação de vagas na rede municipal de ensino é analisada com base em dados de matrículas extraídos do Censo Escolar. Estes dados foram acessados em 11/01/2014 no site do INEP.

Os gastos em educação, em educação infantil e no ensino fundamental dos municípios foram obtidos no banco de dados Finanças do Brasil (FINBRA), disponibilizado online no site da Secretaria do Tesouro Nacional e consultado em 28/03/2014. Os dados referentes aos gastos dos governos dos estados em educação, educação infantil e ensino fundamental estadual também foram acessados no mesmo local e data, mas foram extraídos do banco de dados Execução Orçamentária de Estados [1995-2013]. 
As estimativas populacionais foram coletadas no site do DATASUS em 11/01/2014. Os dados referentes ao partido dos prefeitos e resultados eleitorais foram extraídos o site do TSE na mesma data.

Ao longo do desenvolvimento deste trabalho foi observado que os municípios grandes geram viés considerável nos resultados estimados, de modo que apenas os municípios com até 50 mil habitantes foram mantidos na análise. Estes municípios representam cerca de $90 \%$ dos municípios brasileiros. Os outros 10\% dos municípios influenciam desproporcionalmente os coeficientes dos modelos estimados e por isso foram retirados da amostra.

O período investigado para a criação de vagas nos diferentes níveis de ensino se estende de 2000 a 2012. Para observar o número de vagas criadas no ensino municipal durante um governo, são comparados o número de vagas existentes no último ano da gestão atual com o número de vagas existentes no último ano da gestão anterior. Isto é feito para cada um dos níveis de ensino estudados. Assim, há observações de vagas criadas nas gestões de 2001-2004, 2005-2008 e 2009-2012 para creches, ensino pré-escolar e ensino fundamental.

Devido aos dados referentes aos gastos em educação dos municípios poderem ser separados dos gastos em cultura apenas a partir do ano de 2002 e devido aos dados referentes ao gasto em educação infantil e ensino fundamental estarem disponíveis apenas a partir de 2005, a análise sobre gasto em educação e em suas subfunções cobre período de tempo menor que aquela relativa à criação de vagas na rede municipal de ensino. No caso da educação, avalia-se a variação média do percentual da receita orçamentária destinada à educação em relação à gestão anterior. O mesmo procedimento é seguido com relação aos gastos na educação infantil e no ensino fundamental. A única diferença em relação à criação de vagas é que para o gasto observa-se a variação média do gasto total em educação e suas subfunções durante o mandato dos prefeitos.

Os gastos em educação são examinados para os mandatos de 2005-2008 e de 20092012. Os gastos em educação infantil e ensino fundamental são analisados para o 
mandato de 2009-2012. Todos estes gastos são comparados com os gastos no mandato anterior.

Como este trabalho assume que a variação nas matrículas na rede municipal de ensino e nos gastos em educação e em suas subfunções são indicadores confiáveis das preferências dos prefeitos sobre políticas públicas, são comparados os coeficientes estimados de onze partidos políticos dos prefeitos: DEM, PDT, PMDB, PP, PPS, PR, PSB, PSDB, PT, PTB e PV. Outros partidos que vieram a ser incorporados aos partidos destacados foram incluídos na análise como já pertencentes a estes. Esta escolha visou evitar que houvesse mudança nas variáveis dos partidos políticos utilizadas, isto é, para que partidos que deixaram de existir não fossem extraídos da análise em período subsequente ou para que partidos novos não entrassem no estudo apenas a partir de determinado período. Todas as mudanças feitas são listadas abaixo:

Tabela 4.1: Alterações das Siglas Partidárias

\begin{tabular}{lll}
\hline Antes & Depois & Observações \\
\hline PFL & DEM & O PFL virou o DEM em 2007 \\
\hline PPB & PP & O PPB virou o PP em 2003 \\
\hline PST, PL e & O PST, o PL e o PRONA foram registrados como PR, porque o primeiro \\
PRONA & Poi incorporado ao segundo em 2003 e o segundo e o terceiro \\
\hline PSD & fundaram o PR em 2006 \\
\hline PAN & PTB & O PSD foi incorporado ao PTB em 2003 \\
\hline PRN & PTC & O PAN foi incorporado ao PTB em 2006 \\
\hline PSN & PHS & O PRN se tornou PTC em 2000 \\
\hline
\end{tabular}

Fonte: www.tse.jus.br.

Os partidos selecionados para a análise, após as transformações realizadas, são os partidos que governaram cerca de $90 \%$ dos municípios brasileiros durante o período analisado. Portanto, esta análise utilizou um quadro representativo dos partidos nos municípios brasileiros.

Nos municípios em que houveram eleições suplementares, estes resultados foram considerados definitivos para identificar os partidos dos prefeitos. Esta escolha foi feita para tornar o banco mais representativo das mudanças que ocorreram após as eleições. 


\subsubsection{Variáveis Dependentes}

A variável dependente de cada um dos modelos referentes à criação de vagas na rede municipal de ensino foi criada a partir do número de matrículas existentes no último ano de mandato do prefeito menos o número de matrículas existentes no último ano do mandato do prefeito da gestão anterior. As variáveis de controle referentes à variação no tamanho da rede estadual e particular foram criadas da mesma forma.

A escolha por mensurar a variável dependente em nível se deveu ao fato de que em muitos casos os municípios não apresentam nenhuma matrícula no primeiro período analisado, principalmente quando observamos as vagas em creches. Se fosse feito uso da variação no percentual de matrículas no ensino municipal, os casos em que os municípios inicialmente estão com zero matrículas seriam descartados dos modelos, implicando perda significativa para a análise.

Estatísticas descritivas das variáveis dependentes referentes às vagas criadas nos diferentes níveis de ensino são exibidas na tabela a seguir:

Tabela 4.2: Estatísticas Descritivas das Vagas Criadas na Rede Municipal de Ensino

\begin{tabular}{|c|c|c|c|c|c|c|c|}
\hline Variável & Período & Obs. & Mediana & Média & DP. & Min. & Max. \\
\hline \multirow{3}{*}{$\begin{array}{l}\text { Vagas criadas nas } \\
\text { creches municipais }\end{array}$} & 2001-2004 & 1993 & 0 & 16,68 & 62,70 & -693 & 660 \\
\hline & $2005-2008$ & 1993 & 0 & 18,91 & 76,66 & -648 & 567 \\
\hline & $2009-2012$ & 1993 & 12 & 30,67 & 71,70 & -289 & 520 \\
\hline \multirow{3}{*}{$\begin{array}{c}\text { Vagas criadas nas } \\
\text { pré-escolas } \\
\text { municipais }\end{array}$} & 2001-2004 & 2067 & 14 & 31,92 & 150,60 & -1101 & 1217 \\
\hline & $2005-2008$ & 2067 & -15 & $-34,82$ & 146,04 & -1276 & 647 \\
\hline & $2009-2012$ & 2067 & -2 & $-14,72$ & 122,76 & -1116 & 558 \\
\hline \multirow{3}{*}{$\begin{array}{c}\text { Vagas criadas no } \\
\text { ensino fundamental } \\
\text { municipal }\end{array}$} & 2001-2004 & 2514 & 3 & 54,52 & 450,82 & -3852 & 2904 \\
\hline & $2005-2008$ & 2514 & -61 & $-171,09$ & 482,75 & -3572 & 2916 \\
\hline & 2009-2012 & 2514 & -82 & $-140,10$ & 323,89 & -2596 & 2927 \\
\hline
\end{tabular}

Fonte: Banco de Dados Matrículas e Gastos nos Municípios Brasileiros.

Estas estatísticas refletem as trajetórias descritas no capítulo 1. Os valores mínimos e máximos de vagas criadas nas creches municipais mostram que no último período houve aumento importante na criação de vagas neste nível de ensino. A diferença entre o mínimo de vagas e o máximo ficou menor e o valor mínimo é maior que nos períodos anteriores. O mesmo pode-se dizer da média e mediana de vagas criadas em creches neste período. 
A pré-escola mostra um cenário de ajustamento. Um balanço positivo na criação de vagas no primeiro período é sucedido pela retração na oferta de vagas nos demais períodos. Esta mudança é explicada pela expansão do ensino fundamental para 9 anos que desviou parte da população em idade ideal para a pré-escola para este nível de ensino. Assim, os potenciais efeitos positivos que o FUNDEB poderia ter sobre a expansão de vagas na pré-escola foi compensado pela legislação que expandiu os anos escolares no ensino fundamental.

O ensino fundamental também passou por ajustes. A variação na média de vagas criadas neste nível mostra isto. No primeiro período (2001-2004) a média de vagas criadas foi de 55,38 enquanto nos demais períodos ela foi negativa. Ainda assim, não é possível apontar uma tendência uma vez que o número de vagas criadas no segundo período (2005-2008) é menor que o número de vagas criadas no terceiro período (2009-2012). Este comportamento é bastante similar ao comportamento da criação de vagas em préescolas, entretanto, diferentemente do ocorrido com as pré-escolas, não há redução significativa no número máximo de vagas criadas neste nível de ensino. A redução no número de vagas criadas no ensino fundamental sugere que tenha ocorrido diminuição na distorção idade-série, uma vez que o acesso a este nível de ensino já foi universalizado.

Nos modelos estimados para um mesmo nível de ensino ou tipo de gasto foram inclusos nas amostras apenas os municípios presentes em todos os períodos analisados. Entretanto, utilizar a mesma amostra para todos os modelos aplicados neste estudo implicaria significativa redução no número de casos observados. Deste modo, as amostras variam para os diferentes níveis de ensino ou tipos de gasto, mas permanecem as mesmas quando se observa apenas um nível de ensino ao longo de diferentes períodos.

O número de casos utilizados foi afetado pelos testes realizados para remover casos inconsistentes. Os critérios adotados para classificar observações como inconsistentes são apresentados a seguir: 
Tabela 4.3: Critérios para a Identificação e Exclusão de Casos Inconsistentes

\begin{tabular}{|c|c|}
\hline Variáveis & Critérios de exclusão de casos \\
\hline Receita per capita & $\begin{array}{l}\text { Aumento de mais de } 100 \% \text { de um ano para o outro e a variação percentual da } \\
\text { média da receita per capita do município durante o mandato do prefeito ser maior } \\
\text { que } 100 \% \text {. }\end{array}$ \\
\hline $\begin{array}{l}\text { Transferências do } \\
\text { FUNDEF/FUNDEB }\end{array}$ & $\begin{array}{l}\text { Transferências acima de } \mathrm{R} \$ 10.000,00 \text { sendo que no ano anterior o valor foi igual a } \\
\text { zero. } \\
\text { Transferências acima de } 3 \text { vezes as transferências do ano anterior, sendo que no } \\
\text { ano anterior houve alguma transferência. }\end{array}$ \\
\hline $\begin{array}{c}\text { Matrículas em creches / } \\
\text { pré-escolas }\end{array}$ & $\begin{array}{l}\text { Mais de } 200 \text { matrículas observadas, mas no ano anterior não havia nenhuma } \\
\text { matrícula. } \\
\text { Matrículas acima de } 3 \text { vezes as matrículas no ano anterior, quando estas eram } \\
\text { maiores que zero e menores que cem. } \\
\text { Matrículas acima de } 2 \text { vezes as matrículas no ano anterior, quando estas eram } \\
\text { maiores que cem. }\end{array}$ \\
\hline $\begin{array}{l}\text { Matrículas no ensino } \\
\text { fundamental }\end{array}$ & $\begin{array}{l}\text { Mais de } 300 \text { matrículas observadas, mas no ano anterior não havia nenhuma } \\
\text { matrícula. } \\
\text { Matrículas acima de } 3 \text { vezes as matrículas no ano anterior, quando estas eram } \\
\text { maiores que zero e menores que } 200 \text {. } \\
\text { Matrículas acima de } 2 \text { vezes as observadas no ano anterior, quando estas eram } \\
\text { maiores que } 300 \text {. }\end{array}$ \\
\hline Gastos em educação & Gastos em educação maiores que a receita do município. \\
\hline Gasto com pessoal & Gastos com pessoal maiores que receita do município. \\
\hline $\begin{array}{l}\text { Gastos em educação } \\
\text { infantil / ensino } \\
\text { fundamental }\end{array}$ & Gastos nestas subfunções da educação maiores que os gastos em educação. \\
\hline
\end{tabular}

Elaboração do autor.

A adoção destes critérios de exclusão de casos trouxe maior consistência e confiabilidade para a análise uma vez que a seleção dos casos em nada se relaciona com os partidos políticos e este processo eliminou casos que influenciariam demasiadamente os resultados mediante a apresentação de valores pouco plausíveis.

As variáveis dependentes referentes ao gasto percentual médio do governo municipal em educação, educação infantil e ensino fundamental foi criada a partir da média desses valores durante a gestão observada. Nos casos em que não havia dados para os 4 anos, foi feita a média dos gastos dos três anos disponíveis. Apesar de a variável dependente destes modelos não ser uma variável de diferença, como a utilizada nos modelos que estimam a criação de vagas nas diferentes redes de ensino, a interpretação para ambos os modelos é a mesma devido ao uso de uma variável dependente defasada nas análises dos gastos em educação e em suas subfunções.

O uso de variáveis dependentes defasadas traz ganho considerável para a análise, pois além de transformar os modelos em modelos de variação, este uso também permite 
que se observe em quanto os valores passados das variáveis influenciaram seus valores presentes. Nos modelos sobre as vagas na rede municipal de ensino, estas variáveis não foram incluídas devido à sua forte correlação com as variáveis de demanda. Devido à importância das variáveis de demanda, optou-se por não fazer uso de variáveis dependentes defasadas naqueles modelos.

A seguir são apresentadas as estatísticas descritivas da variável dependente de gasto após a subtração do valor da variável dependente defasada inclusa em cada um dos modelos de gasto:

Tabela 4.4: Estatísticas Descritivas da Variação nos Gastos em Educação e em suas Subfunções na Rede Municipal de Ensino

\begin{tabular}{cccccccc}
\hline Variável & Período & Obs. & Mediana & Média & DP. & Min. & Max. \\
\hline $\begin{array}{c}\text { Variação (\%) do gasto } \\
\text { médio em educação }\end{array}$ & $2005-2008$ & 1501 & $-2,05$ & $-5,97$ & 15,28 & $-78,83$ & 29,45 \\
\hline $\begin{array}{c}\text { Variação (\%) do gasto } \\
\text { médio em educação } \\
\text { infantil }\end{array}$ & $2009-2012$ & 1501 & 1,15 & 1,28 & 3,67 & $-13,85$ & 21,75 \\
\hline $\begin{array}{c}\text { Variação (\%) do gasto } \\
\text { médio em ensino } \\
\text { fundamental }\end{array}$ & $2009-2012$ & 2785 & 1,79 & 2,76 & 6,82 & $-32,47$ & 47,09 \\
\hline
\end{tabular}

Fonte: Banco de Dados Matrículas e Gastos nos Municípios Brasileiros.

O número de casos apresentado na tabela 4.4 é resultado das exclusões descritas acima e dos missings no banco de dados de gastos municipais, em particular o critério para cálculo do gasto médio que requer que os municípios apresentassem observações para pelo menos 3 anos do mandato do prefeito. Uma vez que os gastos em educação foram separados dos gastos em cultura apenas a partir de 2002, não foi possível estender a análise para o período anterior ao mandato de 2001-2004.

É importante observar que na variação percentual do gasto em educação no segundo período observado (2009-2012), a amplitude e o desvio padrão são consideravelmente menores que no período anterior. Isto sugere maior estabilidade dos gastos em educação, o que é confirmado pela análise apresentada no capítulo 5. 


\subsection{Metodologia}

Este tipo de estudo geralmente emprega técnicas de análise em painel, devido à unidade de análise ser o município e o estudo se referir à variação ocorrida no tempo. Entretanto, para manter o uso de uma mesma técnica para a análise das matrículas e dos gastos e porque variáveis importantes apresentam não-estacionaridade, que se mantém mesmo após número razoável de diferenciações, optou-se por fazer uso da técnica de Mínimos Quadrados Ordinários (MQO) com erros padrões robustos.

Esta opção decorreu da observação de que não seria possível fazer uso do modelo de correção de erro (error correction model), pois os erros dos modelos de regressão não são cointegrados. Ou seja, não há estacionaridade entre os erros dos modelos de regressão, o que impossibilita o uso deste modelo (ENGLE; GRANGER, 1987). A impossibilidade de estimar os modelos desenvolvidos com técnicas para a análise de séries temporais e de dados em painel também influenciou a escolha pelas técnicas de MQO com a inclusão de variáveis defasadas.

O uso de modelos de MQO implica que o banco de dados não seja tratado como um painel. Para isto, a análise da criação de vagas na rede municipal de ensino foi fragmentada em três períodos: 2000-2004; 2004-2008 e 2008-2012. Apesar de esta fragmentação multiplicar os modelos e alongar a análise, ela permite observar como os coeficientes estimados para as mesmas variáveis podem variar ao longo do tempo. Há um ganho substantivo para a análise derivada desta escolha.

A existência de heterocedasticidade nos modelos de MQO utilizados fez com que se optasse pelo uso de erros padrões robustos. A comparação de modelos sem e com erros padrões robustos mostrou, também, que os modelos com erros padrões robustos apresentam desvios padrões maiores, o que dificulta que se incorra em erro do tipo I. Ou seja, nos modelos apresentados, esta correção torna mais difícil que seja afirmado que os partidos políticos estão relacionados às variações nos gastos e nas matrículas quando na realidade eles não estão. 


\subsubsection{Modelos de Regressão}

O modelo básico de regressão aplicado nas análises apresenta a seguinte especificação:

$$
Y=\beta_{0}+\beta_{1} X_{1}+\beta_{2} X_{2}+\cdots+u
$$

Nas análises de matrículas, $Y$ corresponde ao número de vagas criadas durante a gestão atual da prefeitura nos diferentes níveis de ensino. Nas análises de gastos em educação e em suas subfunções, $Y$ corresponde, em percentuais, à variação do gasto médio em educação e em suas subfunções na gestão atual quando comparado com estes mesmos valores na gestão passada.

As variáveis independentes e variáveis de controle incluídas nos modelos utilizados para estimar a criação de vagas nos diferentes níveis de ensino são apresentadas nas tabelas a seguir:

Tabela 4.5: Variáveis Incluídas nos Modelos para a Estimação da Criação de Vagas na Rede Municipal de Ensino

\begin{tabular}{l|l|l}
\hline Modelos para as creches & Modelos para as pré-escolas & $\begin{array}{l}\text { Modelos para o ensino } \\
\text { fundamental }\end{array}$ \\
\hline Creches estaduais & Pré-escolas estaduais & Ensino fundamental estadual \\
Creches particulares & Pré-escolas particulares & Ensino fundamental particular \\
L4.Demanda (\%) & L4.Demanda (\%) & L4.Demanda (\%) \\
L4.Pop. idade ideal (\%) & L4.Pop. idade ideal (\%) & L4.Pop. idade ideal (\%) \\
Receita per capita média & Receita per capita média & Receita per capita média \\
L4.Gasto com pessoal (\%) & L4.Gasto com pessoal (\%) & L4.Gasto com pessoal (\%) \\
Gasto médio (\%) dos & Gasto médio (\%) dos \\
governadores em educação & governadores em educação \\
Média de Transferências do & Média de Transferências do & governadores em educação \\
FUNDEF/FUNDEB & FUnDEF/FUNDEB de Transferências do \\
L4.Crescimento das creches & L4.Crescimento das pré- & FUNDEF/FUNDEB \\
municipais & L4.Crescimento do ensino \\
Continuidade & fundamental municipal \\
Distância entre eleito e & Continuidade & Distância entre eleito e \\
segundo mais votado & segundo mais votado \\
Antecedido pelo PSDB & Antecedido pelo PSDB & Distância entre eleito e \\
Antecedido pelo PT & Antecedido pelo PT & segundo mais votado \\
Governador do PMDB & Governador do PMDB & Antecedido pelo PT \\
Governador do PSDB & Governador do PSDB & Governador do PMDB \\
Governador do PT & Governador do PT & Governador do PSDB \\
\hline
\end{tabular}

Fonte: Banco de Dados Matrículas e Gastos nos Municípios Brasileiros.

Os modelos são bastante similares, de modo que a diferença entre eles são as duas primeiras variáveis que servem como variáveis de controle e indicam o número de vagas criadas em cada nível de ensino nas redes estaduais e particulares. 
A variável referente à demanda por vagas indica o percentual estimado de crianças em idade escolar nos municípios que estariam fora da escola. Este percentual corresponde ao número de crianças em idade escolar no município que não estão matriculadas em nenhuma rede de ensino no nível observado. Esta variável é utilizada para estimar qual era a situação do município em relação à cobertura em educação no cenário em que o atual prefeito assumiu seu mandato. Ela corresponde à distância do município em relação a uma situação em que todas suas crianças em idade ideal estão matriculadas. Diminuir para zero a demanda por vagas pode ser entendido como uma estratégia do prefeito para aumentar sua base eleitoral mediante a inclusão de crianças na rede municipal de ensino.

Todas as variáveis referentes a percentuais foram multiplicadas por 100 para facilitar a interpretação dos coeficientes. É possível que a demanda seja negativa em caso de haver mais matrículas em determinado nível de ensino do que crianças em idade ideal no município para frequentar este mesmo nível de ensino. Isto pode tanto ser efeito de significativa distorção idade-série quanto efeito de migração de alunos de outros municípios para frequentar a rede de ensino em determinada cidade.

A população em idade ideal do município corresponde ao percentual da população do município que está em idade ideal para frequentar o nível de ensino observado. Assim como a variável de demanda, esta variável é incorporada nos modelos com seu valor assumido no último ano de mandato do prefeito anterior para que haja um controle pela situação que o prefeito herdou no que diz respeito ao tamanho da população em idade ideal no município para cursar cada nível de ensino em relação ao tamanho total da população local. A população em idade ideal do município ajuda a controlar pela importância que a política de educação pode vir a ter na agenda local em situações em que a parcela da população nesta faixa seja grande o suficiente para fazer com que os prefeitos tenham que dar mais atenção que os demais à política de educação.

Como houve alteração na duração em anos do ensino fundamental, incluindo as crianças de 6 anos no ano inicial do primeiro ciclo, tanto para as pré-escolas quanto para o ensino fundamental houveram mudança acerca da população em idade ideal considerada. No que diz respeito à pré-escola, a população de 4 a 6 anos de idade foi considerada a população em idade ideal para o período de 2000 a 2004 e as crianças de 4 a 5 anos de 
idade foram as consideradas em idade ideal para o período seguinte. No ensino fundamental, as crianças de 7 a 14 anos de idade foram consideradas estar em idade ideal no período de 2000 a 2004 e as crianças de 6 a 14 anos foram consideradas estar em idade ideal o período seguinte.

A receita per capita média do município foi utilizada para controlar pela disponibilidade de recursos do município. Esta variável foi criada a partir da divisão da receita total do município por sua população total. Após esta operação foi calculada a média da receita per capita do município durante os quatro anos da gestão do prefeito.

O gasto percentual médio dos governadores em educação é incluído nos modelos para controlar pela participação do governo do estado no percentual de sua receita destinada à educação. Esta variável equivale ao percentual médio da receita dos estados destinada à educação durante o mandato dos prefeitos. Outras variáveis referentes aos gastos dos governadores em educação, como o gasto médio em valores absolutos ou o gasto em subfunções da educação, não foram incluídas nos modelos devido à apresentação de forte correlação com o partido dos governadores.

O valor médio transferido pelo FUNDEF/FUNDEB aos municípios também equivale à média dos repasses recebidos pelos municípios durante os quatro anos da gestão do prefeito. Sua inclusão nos modelos busca mensurar como esses Fundos influenciaram o policy-making local e as estratégias dos prefeitos em relação à criação de vagas de ensino e aos gastos.

O crescimento prévio do nível de ensino analisado é uma variável binária que assume o valor 1 caso o prefeito anterior tenha aumentado o número de vagas no nível de ensino em questão e assume o valor zero caso isto não tenha ocorrido. Como esta variável necessita que seja feita uma comparação entre a gestão de quatro anos atrás com a gestão de oito anos atrás, ela não é apresentada nos modelos que analisam a criação de vagas do mandato que terminou em 2004, pois os dados para o ano de 1996 não foram incluídos nesta análise devido a inconsistências observadas no banco de dados do Censo Escolar para esses anos.

A variável referente ao crescimento prévio de determinado nível de ensino da rede municipal foi incluída no modelo para testar a hipótese de Rose (1990) de que gestões 
passadas são mais influentes do que as gestões presentes. A confirmação desta hipótese também indica o ajuste do modelo formal apresentado no capítulo anterior ao comportamento dos partidos políticos, pois indica como o crescimento prévio pode influenciar as políticas adotadas pelos prefeitos para continuar criando vagas de ensino.

A continuidade é uma variável binária que indica se o partido do prefeito já estava no controle da prefeitura na gestão passada. Ela assume o valor 1 em caso afirmativo e 0 do contrário. Esta variável é utilizada para testar se a continuidade do partido na prefeitura afeta negativamente a expansão da rede de ensino e a variação dos gastos.

A distância no número de votos obtidos pelo prefeito eleito em relação ao candidato que ficou em segundo lugar é utilizada como um indicador de quanto competitiva foi a última eleição. O esperado é que eleições mais competitivas gerem maior aumento de vagas na rede municipal de ensino. Isto quer dizer que quanto maior a distância entre o candidato eleito e o segundo mais votado, menor é a quantidade esperada de vagas criadas. No caso dos gastos, esta variável é incluída para controlar pela competição eleitoral, mas não necessariamente se espera que maior competição gere maior gasto da receita direcionado para a educação, pois isto implicaria também redução de gasto em outras áreas. Esta escolha só seria justificável caso a educação fosse uma prioridade do eleitorado, porém não é possível afirmar que assim seja.

Nos modelos também é observado se a gestão atual foi antecedida por um prefeito do PSDB ou por um prefeito do PT. Como estes dois partidos apresentam preferências distintas sobre políticas na arena federal, estas variáveis binárias são incluídas nos modelos para testar possíveis tendências nas políticas que estes partidos possam iniciar.

As variáveis referentes ao partido dos governadores se concentram no PMDB, PSDB e PT por estes serem os três principais partidos no cenário nacional e, consequentemente, os três partidos sobre os quais é possível fazer inferências sobre seus posicionamentos ideais em relação às políticas de educação. Estas variáveis assumem três valores (zero, um e dois) que informam: se o prefeito não teve sua gestão coincidente com o governador de tal partido no estado (zero); se o prefeito teve apenas metade de sua gestão coincidente com o governador do partido indicado (1); ou se o prefeito teve seu 
mandato inteiro coincidente com o do governador do partido destacado (2). Esta última implica, necessariamente, que o partido do governador se reelegeu.

Variáveis de controle para estados não foram incluídas porque estas variáveis tendem a apresentar forte correlação com o partido dos governadores que se reelegem, de modo que a forte correlação entre estas variáveis faz com que parte dos estados governados por estes partidos não possa ser incluída nos modelos de regressão, retirando parte significativa do ganho em controlar as variações por estados.

Devido à importância que parte das variáveis tem para o modelo teórico utilizado para interpretar os resultados apresentados no capítulo 5, cada uma das análises para cada um dos períodos gerou 8 modelos de regressão diferentes. O primeiro modelo contém todas as variáveis listadas na tabela anterior até a variável de continuidade, as demais não são incluídas. O segundo modelo apenas substitui a variável de continuidade pela variável da distância entre o candidato eleito e o segundo mais votado. O terceiro substitui esta última variável pela variável que indica se o prefeito foi antecedido pelo prefeito do PSDB; e o quarto substitui esta variável pela variável que indica se o prefeito foi antecedido por um prefeito do PT. O objetivo destes modelos é tornar comparável o quanto estas variáveis, individualmente, colaboram para a compreensão do fenômeno observado. Isto também é feito para captar melhor o efeito estimado que o legado do PSDB e do PT pode ter sobre a gestão atual, pois para captar adequadamente a relação destas variáveis ambas não devem estar no mesmo modelo. Caso contrário, isto seria o mesmo que afirmar que o legado do PSDB pode ser influenciado pelo legado do PT em municípios diferentes e vice versa. Estes quatro modelos incluem e comparam variáveis que, necessariamente, traduziriam alguma estratégia dos prefeitos para adaptar suas políticas às condições políticas observadas no plano local.

O modelo cinco inclui todas as variáveis anteriores e a variável que indica a presença de um governador do PMDB; o sexto modelo substitui esta última variável por outra que indica a presença de um governador do PSDB; e o sétimo modelo exclui a variável do governador do PSDB e coloca no lugar outra que indica a presença de um governador do PT. Novamente, este conjunto de substituições de variáveis foi realizado para estimar o efeito que os governadores destes partidos apresentam sobre as políticas locais, presumindo-se que as decisões que os governadores tomam orientadas por seus 
respectivos partidos não é influenciada pelas decisões que outros governadores de outros partidos estão tomando no mesmo momento.

Por fim, o oitavo modelo inclui todas as variáveis anteriores e é o modelo de referência utilizado para testar a relação entre o partido dos prefeitos e as variações ocorridas nas vagas e nos gastos. Os modelos estimados para cada um dos onze partidos observados são estimados, também, mediante a inclusão e substituição de variáveis binárias que identificam estas siglas partidárias. Deste modo, nunca há duas siglas partidárias no mesmo modelo, pelos mesmos motivos que estas substituições foram realizadas nos modelos anteriores. Interpreta-se que a relação entre um partido e as variações ocorridas nas matrículas e nos gastos não estão relacionadas às variações ocorridas nestes mesmos objetos devido à ação de outros partidos em outros municípios. Para facilitar a interpretação e comparação do efeito estimado para os partidos nestes onze novos modelos, os coeficientes estimados para os partidos são plotados em gráficos juntamente com seus intervalos de confiança e estes modelos são omitidos.

Os modelos estimados para os gastos em educação, em ensino infantil e fundamental apresentam similaridade considerável com os modelos estimados para as vagas em creches, pré-escolas e ensino fundamental. As variáveis independentes e de controle inclusas nestes modelos são exibidas a seguir: 
Tabela 4.6: Variáveis Incluídas nos Modelos para a Estimação da Variação nos Gastos da Rede Municipal de Ensino

\begin{tabular}{|c|c|c|}
\hline $\begin{array}{l}\text { Modelos para o gasto em } \\
\text { educação (\%) }\end{array}$ & $\begin{array}{l}\text { Modelos para o gasto em } \\
\text { educação infantil (\%) }\end{array}$ & $\begin{array}{l}\text { Modelos para o gasto em } \\
\text { ensino fundamental (\%) }\end{array}$ \\
\hline $\begin{array}{l}\text { L4.Gasto (\%) médio em } \\
\text { educação }\end{array}$ & $\begin{array}{l}\text { L4.Gasto (\%) médio em } \\
\text { educação infantil } \\
\text { Pop. idade ideal (\%) }\end{array}$ & $\begin{array}{l}\text { L4.Gasto (\%) médio em ensino } \\
\text { fundamental } \\
\text { Pop. idade ideal (\%) }\end{array}$ \\
\hline $\begin{array}{l}\text { Média das matrículas na rede } \\
\text { municipal de ensino }\end{array}$ & $\begin{array}{l}\text { Média de matrículas na } \\
\text { educação infantil municipal } \\
\text { Média de matrículas na } \\
\text { educação infantil estadual } \\
\text { Receita per capita média }\end{array}$ & $\begin{array}{l}\text { Média de matrículas no } \\
\text { ensino fundamental municipal } \\
\text { Média de matrículas no } \\
\text { ensino fundamental estadual } \\
\text { Receita per capita média }\end{array}$ \\
\hline $\begin{array}{l}\text { Gasto médio (\%) dos } \\
\text { governadores em educação }\end{array}$ & $\begin{array}{l}\text { Gasto médio (\%) dos } \\
\text { governadores em educação }\end{array}$ & $\begin{array}{l}\text { Gasto médio (\%) dos } \\
\text { governadores em ensino } \\
\text { fundamental }\end{array}$ \\
\hline Continuidade & Continuidade & Continuidade \\
\hline $\begin{array}{l}\text { Distância entre eleito e } \\
\text { segundo mais votado } \\
\text { Antecedido pelo PSDB }\end{array}$ & $\begin{array}{l}\text { Distância entre eleito e } \\
\text { segundo mais votado } \\
\text { Antecedido pelo PSDB }\end{array}$ & $\begin{array}{l}\text { Distância entre eleito e } \\
\text { segundo mais votado } \\
\text { Antecedido pelo PSDB }\end{array}$ \\
\hline Antecedido pelo PT & Antecedido pelo PT & Antecedido pelo PT \\
\hline Governador do PMDB & Governador do PMDB & Governador do PMDB \\
\hline Governador do PSDB & Governador do PSDB & Governador do PSDB \\
\hline Governador do PT & Governador do PT & Governador do PT \\
\hline
\end{tabular}

Fonte: Banco de Dados Matrículas e Gastos nos Municípios Brasileiros.

Estes modelos pretendem avaliar as alterações ocorridas em relação ao gasto médio em educação, em educação infantil e em ensino fundamental em comparação com o gasto médio nestas mesmas áreas pelo governo anterior. Estes modelos incluem variáveis dependentes defasadas com o valor do gasto percentual médio da gestão anterior em cada uma das atribuições destacadas.

A média das matrículas na rede municipal de ensino de acordo com o nível de ensino correspondente ao gasto observado é uma variável de controle utilizada para mensurar se a variação no tamanho da rede de ensino municipal influencia no percentual gasto nas áreas observadas. Esta variável também traduz efeitos do FUNDEB, pois há forte correlação entre estas variáveis. Isto é esperado, uma vez que as transferências do FUNDEB são condicionadas aos municípios e estados de acordo com o número de matrículas em suas redes de ensino.

O gasto percentual médio dos governos estaduais em educação foi mantido como variável de controle nestes modelos e apenas no modelo referente aos gastos dos prefeitos com o ensino fundamental esta variável foi substituída pelo percentual que os governadores gastaram com o ensino fundamental. Isto foi feito para obter maior 
precisão nas estimações. $\mathrm{Na}$ análise dos gastos no ensino fundamental foram incluídos apenas os municípios que também estavam presentes nos modelos de criação de vagas no ensino fundamental. Devido à falta de alguns dados sobre gastos, há número menor de municípios nestas análises, mas todos os municípios nela incluídos também estão presentes nas análises de matrículas.

Na educação infantil não foi possível incluir uma variável que indicasse o gasto dos governos estaduais com esta subfunção por haver omissão da declaração destes valores em muitos estados. Assim, nestes modelos foi mantido o percentual que o governo do estado gastou em educação como variável de controle para os gastos do governo do estado. As demais variáveis incluídas nos modelos repetem as apresentadas nos modelos para a criação de vagas na rede municipal de ensino.

Durante o processo de análise destes dados, os mesmos passos são seguidos em relação aos modelos de regressão desenvolvidos para a avaliação da criação de vagas na rede municipal de ensino. Assim, são gerados oito modelos para testar as variáveis que, de alguma forma, refletem estratégias políticas em nível local e são apresentados gráficos com os efeitos estimados dos partidos dos prefeitos sobre os gastos.

\subsection{Posicionamento Partidário}

Um dos pontos que distingue o presente trabalho de outros que buscam estudar o efeito dos partidos políticos sobre políticas públicas é não pressupor que partidos de esquerda propõem mais políticas sociais e os de direita menos. Em uma federação centralizada como a brasileira, onde os governos subnacionais são obrigados a gastar parte significativa de seus recursos em políticas sociais, a opção de governos de direita por reduzir os gastos sociais seria subótima, pois eles ainda gastariam parte elevada de seus recursos em políticas sociais, mas seria mais visível ao eleitorado que partidos de esquerda gastam mais nessas políticas. Como afirmado no capítulo 3, o esperado neste caso seria que partidos com posicionamento específico sobre determinadas políticas se diferenciassem dos demais e que os demais partidos tentassem se assemelhar a seus antecessores quando estes tivessem preferências específicas sobre políticas aprovadas pelo eleitorado. 
Esta dissertação adotou uma estratégia distinta daquela que atribui exogenamente preferências aos partidos políticos. Estas foram determinadas a partir do posicionamento dos partidos na arena federal. A hipótese de que partidos com preferências sobre políticas possuem uma agenda que pode ser apresentada de forma única, mesmo nos diferentes níveis de governo de uma federação, é uma hipótese que envolve fortes pressupostos de coesão e disciplina partidárias. Ainda assim, é difícil iniciar uma pesquisa sobre influência partidária flexibilizando este pressuposto, que continua central para esta agenda de pesquisa.

Uma vez assumido que partidos políticos com preferências sobre políticas tendem a agir como atores unitários, é possível observar seu comportamento na arena em que estas preferências são mais claramente explicitadas -- no caso brasileiro, a arena federal -- e formular hipóteses sobre seu comportamento nos governos subnacionais. Como o comportamento dos partidos políticos no Congresso Nacional se baseia em uma lógica de governo e oposição (IZUMI, 2013; LEONI, 2002), não é necessário acompanhar cada um dos partidos políticos para captar seus principais posicionamentos nas matérias votadas. Como forma de apresentar uma síntese destes posicionamentos, foram acompanhados o PMDB, o PSDB e o PT, com base em pronunciamentos partidários e no conteúdo de suas propostas durante a tramitação da LDB, do FUNDEF, do PNE de 2001 e do FUNDEB na Câmara dos Deputados. Com base nesta análise, nesta seção, são apresentados os posicionamentos do PT e do PSDB em relação à política de educação bem como o motivo pelo qual se acredita que o PMDB é um partido sem preferências sobre esta política, e que, portanto, se comportará como um partido $\boldsymbol{O}$.

\subsubsection{PMDB}

O PMDB, como nas demais áreas de políticas, tende a ser um partido de apoio do governo em seus posicionamentos sobre a política de educação. Na maior parte das discussões sobre as emendas constitucionais e projetos de leis que versaram sobre a questão educacional, seu posicionamento foi a favor do projeto do governo. Seu apoio ao FUNDEF foi feito mediante o argumento de que o Fundo seria um avanço em relação à situação presente do Brasil, apesar de não representar tudo o que o país precisava 
(BRASIL, 1996). Quando foi a vez do FUNDEB, seus parlamentares se alinharam ao governo afirmando ser sua aprovação um grande passo (BRASIL, 2006c). Apesar de haver vozes destoantes no partido em relação à aprovação do FUNDEB (BRASIL, 2006e), prevaleceu a posição de apoio à aprovação do Fundo.

\subsubsection{PSDB}

Em matéria de políticas de educação, o PSDB se destacou dos demais partidos durante o governo FHC ao defender a priorização do ensino fundamental. Este posicionamento se materializou na Emenda Constitucional 14/96, que criou o FUNDEF. Durante os governos $\mathrm{FHC}$, O PSDB teve seu posicionamento em educação centrado no ensino fundamental. Mas após ter deixado o governo, mais precisamente durante a votação da Emenda Constitucional 53/06, que criou o FUNDEB, os pronunciamentos do partido foram favoráveis ao FUNDEB, como uma continuidade do FUNDEF (BRASIL, 2006b). O partido em momento algum escondeu a prioridade dada ao ensino fundamental quando escolheu fazer uma reforma na educação, mas quando esteve na oposição, não fez oposição efetiva ao FUNDEB, pois o fundo implicou antes uma ampliação do FUNDEF que sua revogação.

\subsubsection{PT}

Durante todo o processo de discussão do FUNDEF, o PT se posicionou contrário a tal reforma. $\mathrm{O}$ argumento básico do partido foi de que a emenda fazia parte de um processo de desconstitucionalização do setor educacional, ou de que a priorização ao ensino fundamental significaria deixar os outros níveis de ensino de lado (BRASIL, 2006d). Durante o governo FHC, o discurso do PT era de que a educação básica como um todo deveria ser priorizada, ao invés de dar foco apenas ao ensino fundamental, como buscava o governo (BRASIL, 2000). Os discursos do PT se materializaram em políticas quando a Emenda Constitucional do FUNDEB foi aprovada ao final do primeiro mandato do governo Lula (2006). Apesar de a primeira versão da Emenda não incluir as creches no cálculo de repasses do Fundo (PINTO, 2007), novas negociações no interior do partido e no Congresso garantiram esta inclusão (BRASIL, 2006a). 
Como o PSDB e o PT lideraram o governo e a oposição em momentos diferentes e como o comportamento dos partidos no Congresso seguiu a lógica de governo e oposição, pesquisar o posicionamento dos demais partidos políticos em educação pouco acrescenta em conteúdo às hipóteses que podem ser formuladas a partir das posições destes dois partidos. O posicionamento do PMDB é tomado como suficiente para representar os partidos que estão mais ao centro do sistema partidário brasileiro, que ora oscilam para o PT, ora para o PSDB. Não parece razoável fazer inferências sobre as preferências do PMDB em relação à política de educação porque o posicionamento do partido muda de acordo com o partido no governo.

\subsubsection{Influência do Partido dos Governadores}

De acordo com o modelo apresentado no capítulo 3, deve-se testar, também, a relação entre a posição dos governadores e a expansão das matrículas e dos gastos na rede municipal de ensino. Os governadores têm capacidade de influenciar a agenda dos prefeitos de seus respectivos municípios mediante parcerias ou expansões/retrações na própria rede de ensino estadual. Desta forma, os governadores, assim como o governo federal, podem diminuir os custos para que os prefeitos adotem certas políticas, de modo que podem induzir a implementação de políticas de educação nos municípios.

Exemplos da influência dos governadores sobre a política local de educação podem ser encontrados em Arretche (2000) e em Gomes (2009). As autoras mostram que incentivos vindos dos governos estaduais tiveram papel central na expansão da oferta de matrículas no ensino fundamental municipal nos estados em que os governadores apresentaram adotaram políticas que favoreceram a municipalização. Uma vez que os governadores podem induzir a adoção de determinadas políticas no plano local, cabe observar se esta indução ocorre de acordo com a agenda defendida pelo partido do governador.

A inclusão dos partidos dos governadores aos modelos adiciona uma camada a mais de complexidade à análise que é necessária para que seja observado como os três principais partidos aqui tratados se comportam nos governos estaduais em relação aos governos locais. Esta comparação é apresentada no próximo capítulo. 


\subsection{Hipóteses}

As hipóteses elaboradas a partir da observação do posicionamento do PMDB, do PSDB e do PT sobre políticas de educação na arena federal e aquelas elaboradas a partir da observação dos dados apresentados nos capítulos anteriores são apresentadas abaixo:

1) As transferências do FUNDEF e o FUNDEB tiveram efeitos distintos sobre as matrículas e sobre a forma como os prefeitos distribuíram seus gastos em educação.

2) Os prefeitos do PSDB se destacam na criação de vagas no ensino fundamental municipal.

3) Os prefeitos do PT tendem a ser mais responsivos na política educacional às demandas locais que os prefeitos dos demais partidos.

4) A variação na distribuição dos gastos dos prefeitos em educação, educação infantil e ensino fundamental refletem posicionamentos de seus respectivos partidos políticos adotados na arena federal.

5) Os governadores influenciam a criação de vagas na rede municipal de ensino e os gastos em educação dos prefeitos de acordo com o posicionamento de seus respectivos partidos na arena federal.

6) A demanda por vagas é central na expansão da rede municipal de educação.

\subsection{Conclusão}

Neste capítulo foi discorrido sobre o uso de modelos de MQO com erros padrões robustos e variáveis defasadas como alternativas viáveis para a exploração do problema de pesquisa exposto. Foram apresentadas todas as variáveis inclusas nos modelos e as hipóteses com as quais se trabalha. Deu-se destaque ao papel do partido dos governadores pois os governadores também são atores importantes com poder para influenciar a política local de educação. Neste caso, é importante saber se esta influência é exercida mediante diretrizes partidárias. O capítulo seguinte apresenta os modelos estimados e os resultados obtidos. 


\section{CAPÍTULO 5: GOVERNOS MUNICIPAIS E POLÍTICA PARTIDÁRIA - A POLÍTICA DE EDUCAÇÃO NOS MUNICÍPIOS BRASILEIROS}

"Se a vontade do homem é livre, isto é, se cada um de nós pode agir como quer, a História inteira não passa de uma série de azares incoerentes”

(Leon Tolstói)

O objetivo deste capítulo é apresentar o resultado da análise sobre as relações entre os partidos políticos e a política municipal de educação, política esta que é observada na criação de vagas na rede municipal de ensino e na variação nos gastos em educação e em suas subfunções. Os resultados encontrados sugerem que os prefeitos orientam suas políticas de criação de vagas no ensino municipal basicamente busacndo atender a demanda existente em seu município. Dada esta prioridade, não se observam diferenças importantes entre os partidos políticos no que diz respeito às políticas municipais de educação, mesmo nas poucas vezes em que uma relação estatisticamente significativa entre as políticas e o pertencimento partidário do prefeito é observada.

Ainda que seja possível encontrar uma relação estatisticamente significativa entre os partidos dos governadores e as políticas adotadas pelas redes municipais de ensino de seus respectivos estados, sendo mesmo possível diferenciar o comportamento estimado destes partidos, os resultados encontrados não possibilitam vincular as políticas adotadas pelos governadores com a agenda de seus respectivos partidos na arena federal.

O capítulo se divide em quatro seções. Na primeira seção são apresentados os resultados dos modelos referentes à criação de vagas na rede municipal de ensino. $\mathrm{Na}$ segunda seção são apresentados os resultados dos modelos referentes à variação no gasto médio em educação, em educação infantil e em ensino fundamental. Na terceira seção discorre-se sobre o resultado dos testes de hipóteses realizados. Na quarta seção é apresentada a síntese dos achados deste capítulo. 


\subsection{Criação de Vagas na Rede Municipal de Ensino}

Como mostrado no capítulo 1 , a rede municipal de ensino apresenta características específicas para cada nível de ensino. Brevemente, pode-se destacar que a expansão do acesso às creches foi consideravelmente limitada no período recente; que a expansão das pré-escolas foi negativamente afetada pela implementação do ensino fundamental de nove anos e que o ensino fundamental, já universalizado, apresenta uma dinâmica inercial mais forte que os demais níveis de ensino no que diz respeito à expansão das matrículas das redes municipais de ensino.

A seguir são exibidos os modelos estimados para a criação de vagas em creches, em préescolas e no ensino fundamental, respectivamente. A análise do papel dos partidos políticos, segundo estes modelos, é apresentada em subseção posterior.

\subsubsection{Criação de Vagas nas Creches Municipais}

A baixa cobertura das creches poderia servir de estímulo para que os prefeitos fizessem uso da criação de vagas neste nível de ensino como meio de se aproximar dos eleitores e ganhar votos. Se por um lado o atendimento à demanda corrobora com este raciocínio, o efeito estimado do crescimento da rede de creches municipais na gestão anterior mostra que os prefeitos não ajustam a criação de vagas durante seu mandato à expansão ocorrida na gestão passada. Isto sugere que, uma vez que a demanda seja mantida constante, a criação de vagas da gestão anterior não é importante para explicar a criação de vagas da gestão atual e dificilmente influencia as escolhas dos prefeitos. Nas tabelas a seguir são exibidos os modelos utilizados para estimar a criação de vagas em creches municipais: 
Tabela 5.7: Modelos de Regressão para a Criação de Vagas em Creches Municipais (2000-2004)

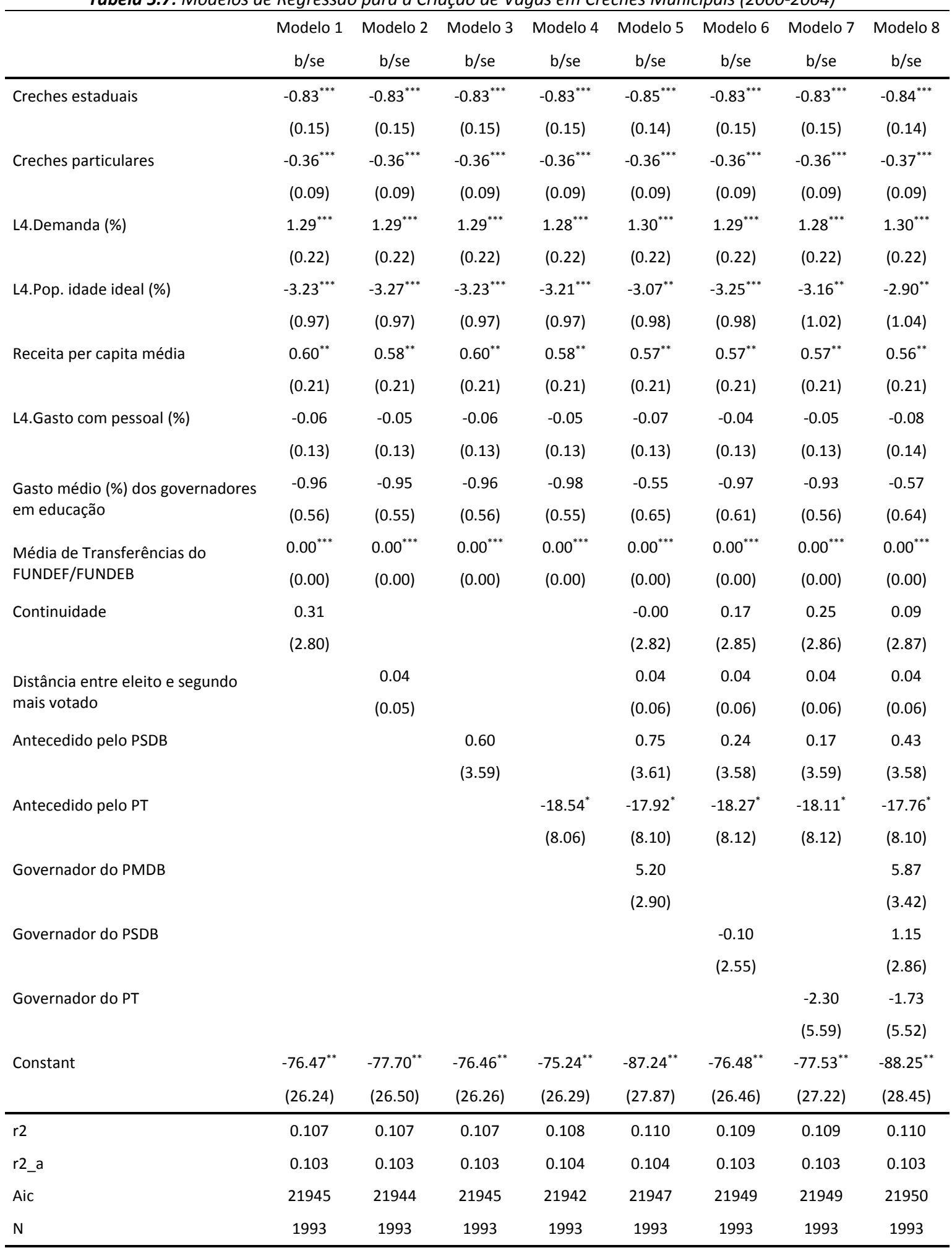

$* \mathrm{p}<0.05, * * \mathrm{p}<0.01, * * * \mathrm{p}<0.001$

Fonte: Banco de Dados Matrículas e Gastos nos Municípios Brasileiros. 
Tabela 5.8: Modelos de Regressão para a Criação de Vagas em Creches Municipais (2004 - 2008)

\begin{tabular}{|c|c|c|c|c|c|c|c|c|}
\hline & $\begin{array}{c}\text { Modelo } 1 \\
\text { b/se }\end{array}$ & $\begin{array}{c}\text { Modelo } 2 \\
\text { b/se }\end{array}$ & $\begin{array}{c}\text { Modelo } 3 \\
\text { b/se }\end{array}$ & $\begin{array}{c}\text { Modelo } 4 \\
\text { b/se }\end{array}$ & $\begin{array}{c}\text { Modelo } 5 \\
\text { b/se }\end{array}$ & $\begin{array}{c}\text { Modelo } 6 \\
\text { b/se }\end{array}$ & $\begin{array}{c}\text { Modelo } 7 \\
\text { b/se }\end{array}$ & $\begin{array}{c}\text { Modelo } 8 \\
\text { b/se }\end{array}$ \\
\hline \multirow[t]{2}{*}{ Creches estaduais } & -0.58 & -0.57 & -0.58 & -0.59 & -0.57 & -0.56 & -0.59 & -0.57 \\
\hline & $(0.43)$ & $(0.44)$ & $(0.43)$ & $(0.42)$ & $(0.42)$ & $(0.42)$ & $(0.41)$ & $(0.42)$ \\
\hline \multirow[t]{2}{*}{ Creches particulares } & $-0.24^{* *}$ & $-0.23^{*}$ & $-0.23^{*}$ & $-0.23^{*}$ & $-0.24^{* *}$ & $-0.24^{* *}$ & $-0.24^{* *}$ & $-0.24^{* *}$ \\
\hline & $(0.09)$ & $(0.09)$ & $(0.09)$ & $(0.09)$ & $(0.09)$ & $(0.09)$ & $(0.09)$ & $(0.09)$ \\
\hline \multirow[t]{2}{*}{ L4.Demanda (\%) } & $1.70^{* * *}$ & $1.70^{* * *}$ & $1.69^{* * *}$ & $1.69^{* * *}$ & $1.66^{* * *}$ & $1.71^{* * *}$ & $1.69^{* * *}$ & $1.65^{* * *}$ \\
\hline & $(0.26)$ & $(0.26)$ & $(0.26)$ & $(0.26)$ & $(0.26)$ & $(0.26)$ & $(0.26)$ & $(0.26)$ \\
\hline \multirow[t]{2}{*}{ L4.Pop. idade ideal (\%) } & $-6.45^{* * *}$ & $-6.53^{* * *}$ & $-6.43^{* * *}$ & $-6.42^{* * *}$ & $-6.53^{* * *}$ & $-6.75^{* * *}$ & $-6.25^{* * *}$ & $-6.32^{* * *}$ \\
\hline & $(1.13)$ & $(1.13)$ & $(1.12)$ & $(1.12)$ & $(1.13)$ & $(1.10)$ & $(1.12)$ & $(1.09)$ \\
\hline \multirow[t]{2}{*}{ Receita per capita média } & $0.58^{*}$ & $0.53^{*}$ & $0.55^{*}$ & $0.55^{*}$ & $0.52^{*}$ & $0.55^{*}$ & $0.50^{*}$ & $0.47^{*}$ \\
\hline & $(0.23)$ & $(0.23)$ & $(0.23)$ & $(0.23)$ & $(0.23)$ & $(0.23)$ & $(0.23)$ & $(0.24)$ \\
\hline \multirow[t]{2}{*}{ L4.Gasto com pessoal (\%) } & 0.02 & 0.07 & 0.06 & 0.06 & 0.07 & 0.09 & -0.04 & 0.01 \\
\hline & $(0.25)$ & $(0.25)$ & $(0.25)$ & $(0.25)$ & $(0.25)$ & $(0.26)$ & $(0.26)$ & $(0.27)$ \\
\hline \multirow{2}{*}{$\begin{array}{l}\text { Gasto médio (\%) dos governadores } \\
\text { em educação }\end{array}$} & -0.26 & -0.21 & -0.21 & -0.21 & -1.34 & -0.43 & -0.34 & -1.37 \\
\hline & $(0.60)$ & $(0.59)$ & $(0.59)$ & $(0.59)$ & $(0.73)$ & $(0.67)$ & $(0.59)$ & $(0.74)$ \\
\hline \multirow{2}{*}{$\begin{array}{l}\text { Média de Transferências do } \\
\text { FUNDEF/FUNDEB }\end{array}$} & $0.00^{* * *}$ & $0.00^{* * *}$ & $0.00^{* * *}$ & $0.00^{* * *}$ & $0.00^{* * *}$ & $0.00^{* * *}$ & $0.00^{* * *}$ & $0.00^{* * *}$ \\
\hline & $(0.00)$ & $(0.00)$ & $(0.00)$ & $(0.00)$ & $(0.00)$ & $(0.00)$ & $(0.00)$ & $(0.00)$ \\
\hline \multirow{2}{*}{$\begin{array}{l}\text { L4.Crescimento das creches } \\
\text { municipais }\end{array}$} & -2.22 & -2.34 & -2.48 & -2.48 & -3.70 & -2.42 & -2.60 & -4.09 \\
\hline & $(4.24)$ & $(4.24)$ & $(4.25)$ & $(4.23)$ & $(4.24)$ & $(4.26)$ & $(4.30)$ & $(4.26)$ \\
\hline \multirow[t]{2}{*}{ Continuidade } & $-8.65^{*}$ & & & & $-8.80^{*}$ & $-9.03^{*}$ & $-8.16^{*}$ & $-8.14^{*}$ \\
\hline & (3.69) & & & & $(3.66)$ & $(3.70)$ & $(3.76)$ & $(3.74)$ \\
\hline \multirow{2}{*}{$\begin{array}{l}\text { Distância entre eleito e segundo } \\
\text { mais votado }\end{array}$} & & 0.11 & & & 0.12 & 0.12 & 0.12 & 0.12 \\
\hline & & $(0.07)$ & & & $(0.07)$ & $(0.07)$ & $(0.07)$ & $(0.07)$ \\
\hline \multirow[t]{2}{*}{ Antecedido pelo PSDB } & & & -0.60 & & 1.27 & 0.17 & -0.06 & 1.04 \\
\hline & & & $(4.81)$ & & $(4.76)$ & $(4.79)$ & $(4.80)$ & $(4.76)$ \\
\hline \multirow[t]{2}{*}{ Antecedido pelo PT } & & & & 7.67 & 9.27 & 9.82 & 9.08 & 8.71 \\
\hline & & & & $(12.36)$ & $(12.63)$ & $(12.45)$ & $(12.46)$ & $(12.67)$ \\
\hline \multirow[t]{2}{*}{ Governador do PMDB } & & & & & $10.25^{* * *}$ & & & $9.49^{* *}$ \\
\hline & & & & & $(3.01)$ & & & $(3.43)$ \\
\hline \multirow[t]{2}{*}{ Governador do PSDB } & & & & & & -1.95 & & -0.40 \\
\hline & & & & & & $(2.01)$ & & $(2.29)$ \\
\hline \multirow[t]{2}{*}{ Governador do PT } & & & & & & & -8.17 & -6.85 \\
\hline & & & & & & & $(4.20)$ & $(4.74)$ \\
\hline \multirow[t]{2}{*}{ Constant } & $-105.70^{* *}$ & $-111.85^{* *}$ & $-109.52^{* *}$ & $-109.83^{* *}$ & $-92.58^{* *}$ & $-104.52^{* *}$ & $-102.34^{* *}$ & $-87.87^{*}$ \\
\hline & $(34.56)$ & $(34.90)$ & $(34.66)$ & (34.65) & $(34.52)$ & (34.95) & $(35.45)$ & (35.58) \\
\hline r2 & 0.108 & 0.106 & 0.105 & 0.105 & 0.115 & 0.109 & 0.111 & 0.116 \\
\hline r2_a & 0.103 & 0.101 & 0.101 & 0.101 & 0.109 & 0.103 & 0.105 & 0.109 \\
\hline Aic & 22746 & 22750 & 22752 & 22752 & 22738 & 22751 & 22747 & 22739 \\
\hline $\mathrm{N}$ & 1993 & 1993 & 1993 & 1993 & 1993 & 1993 & 1993 & 1993 \\
\hline
\end{tabular}

$* \mathrm{p}<0.05, * * \mathrm{p}<0.01, * * * \mathrm{p}<0.001$

Fonte: Banco de Dados Matrículas e Gastos nos Municípios Brasileiros. 
Tabela 5.9: Modelos de Regressão para a Criação de Vagas em Creches Municipais (2008 - 2012)

\begin{tabular}{|c|c|c|c|c|c|c|c|c|}
\hline & $\begin{array}{c}\text { Modelo } 1 \\
\text { b/se }\end{array}$ & $\begin{array}{c}\text { Modelo } 2 \\
\text { b/se }\end{array}$ & $\begin{array}{c}\text { Modelo } 3 \\
\text { b/se }\end{array}$ & $\begin{array}{c}\text { Modelo } 4 \\
\text { b/se }\end{array}$ & $\begin{array}{c}\text { Modelo } 5 \\
\text { b/se }\end{array}$ & $\begin{array}{c}\text { Modelo } 6 \\
\text { b/se }\end{array}$ & $\begin{array}{c}\text { Modelo } 7 \\
\text { b/se }\end{array}$ & $\begin{array}{c}\text { Modelo } 8 \\
\text { b/se }\end{array}$ \\
\hline \multirow[t]{2}{*}{ Creches estaduais } & $-1.62^{*}$ & $-1.63^{*}$ & $-1.63^{*}$ & $-1.63^{*}$ & $-1.61^{*}$ & $-1.61^{*}$ & $-1.52^{*}$ & $-1.53^{*}$ \\
\hline & $(0.67)$ & $(0.66)$ & $(0.66)$ & $(0.66)$ & $(0.67)$ & $(0.66)$ & $(0.68)$ & $(0.67)$ \\
\hline \multirow[t]{2}{*}{ Creches particulares } & -0.12 & -0.12 & -0.12 & -0.12 & -0.13 & -0.13 & -0.13 & -0.13 \\
\hline & $(0.10)$ & $(0.10)$ & $(0.10)$ & $(0.10)$ & $(0.10)$ & $(0.10)$ & $(0.10)$ & $(0.10)$ \\
\hline \multirow[t]{2}{*}{ L4.Demanda (\%) } & $0.54^{* * *}$ & $0.54^{* *}$ & $0.54^{* * *}$ & $0.54^{* *}$ & $0.53^{* *}$ & $0.57^{* * *}$ & $0.61^{* * *}$ & $0.61^{* * *}$ \\
\hline & $(0.16)$ & $(0.16)$ & $(0.16)$ & $(0.16)$ & $(0.16)$ & $(0.16)$ & $(0.16)$ & $(0.16)$ \\
\hline \multirow[t]{2}{*}{ L4.Pop. idade ideal (\%) } & $-9.63^{* * *}$ & $-9.68^{* * *}$ & $-9.66^{* * *}$ & $-9.66^{* * *}$ & $-9.91^{* * *}$ & $-9.22^{* * *}$ & $-9.96^{* * *}$ & $-9.88^{* * *}$ \\
\hline & (1.05) & $(1.04)$ & (1.05) & (1.04) & $(1.04)$ & (1.01) & (1.04) & (1.03) \\
\hline \multirow[t]{2}{*}{ Receita per capita média } & $0.42^{*}$ & $0.42^{*}$ & $0.43^{*}$ & $0.43^{*}$ & 0.37 & 0.35 & $0.39^{*}$ & 0.31 \\
\hline & (0.19) & $(0.20)$ & $(0.19)$ & (0.19) & $(0.20)$ & (0.19) & $(0.19)$ & $(0.19)$ \\
\hline \multirow[t]{2}{*}{ L4.Gasto com pessoal (\%) } & $-0.66^{* *}$ & $-0.68^{* *}$ & $-0.68^{* *}$ & $-0.67^{* *}$ & $-0.62^{* *}$ & $-0.63^{* *}$ & $-0.69^{* *}$ & $-0.64^{* *}$ \\
\hline & $(0.23)$ & $(0.23)$ & $(0.23)$ & $(0.23)$ & $(0.23)$ & $(0.23)$ & $(0.22)$ & $(0.22)$ \\
\hline \multirow{2}{*}{$\begin{array}{l}\text { Gasto médio (\%) dos governadores } \\
\text { em educação }\end{array}$} & 0.21 & 0.21 & 0.21 & 0.23 & 0.27 & 0.25 & -0.08 & 0.04 \\
\hline & $(0.43)$ & $(0.43)$ & $(0.43)$ & $(0.43)$ & $(0.43)$ & $(0.43)$ & $(0.43)$ & $(0.44)$ \\
\hline \multirow{2}{*}{$\begin{array}{l}\text { Média de Transferências do } \\
\text { FUNDEF/FUNDEB }\end{array}$} & $0.00^{* * *}$ & $0.00^{* * *}$ & $0.00^{* * *}$ & $0.00^{* * *}$ & $0.00^{* * *}$ & $0.00^{* * *}$ & $0.00^{* * *}$ & $0.00^{* * *}$ \\
\hline & $(0.00)$ & $(0.00)$ & $(0.00)$ & $(0.00)$ & $(0.00)$ & $(0.00)$ & $(0.00)$ & $(0.00)$ \\
\hline \multirow{2}{*}{$\begin{array}{l}\text { L4.Crescimento das creches } \\
\text { municipais }\end{array}$} & -0.22 & -0.21 & -0.21 & -0.28 & -0.72 & 0.43 & -0.58 & -0.46 \\
\hline & $(3.36)$ & (3.36) & $(3.36)$ & $(3.36)$ & (3.37) & (3.34) & (3.31) & $(3.32)$ \\
\hline \multirow[t]{2}{*}{ Continuidade } & 2.55 & & & & 2.36 & 2.42 & 1.05 & 1.57 \\
\hline & (3.10) & & & & (3.16) & (3.15) & (3.11) & (3.13) \\
\hline \multirow{2}{*}{$\begin{array}{l}\text { Distância entre eleito e segundo } \\
\text { mais votado }\end{array}$} & & 0.03 & & & 0.02 & 0.02 & 0.01 & 0.00 \\
\hline & & $(0.06)$ & & & $(0.06)$ & $(0.06)$ & $(0.06)$ & $(0.06)$ \\
\hline \multirow[t]{2}{*}{ Antecedido pelo PSDB } & & & 0.58 & & 1.40 & -2.01 & -2.70 & -3.54 \\
\hline & & & (3.99) & & (3.97) & (3.99) & $(4.00)$ & (3.98) \\
\hline \multirow[t]{2}{*}{ Antecedido pelo PT } & & & & 4.81 & 3.81 & 2.98 & 4.04 & 2.58 \\
\hline & & & & (6.55) & $(6.62)$ & (6.54) & $(6.56)$ & (6.55) \\
\hline \multirow[t]{2}{*}{ Governador do PMDB } & & & & & 9.35 & & & 8.26 \\
\hline & & & & & $(4.91)$ & & & (5.09) \\
\hline \multirow[t]{2}{*}{ Governador do PSDB } & & & & & & $9.83^{* * *}$ & & $6.14^{*}$ \\
\hline & & & & & & $(2.45)$ & & $(2.73)$ \\
\hline \multirow[t]{2}{*}{ Governador do PT } & & & & & & & $-20.77^{* * *}$ & $-17.41^{* * *}$ \\
\hline & & & & & & & $(3.05)$ & $(3.38)$ \\
\hline \multirow[t]{2}{*}{ Constant } & 32.68 & 34.10 & 34.39 & 33.79 & 33.55 & 20.66 & 37.59 & 30.81 \\
\hline & $(22.71)$ & $(22.58)$ & $(22.64)$ & $(22.67)$ & $(22.71)$ & $(22.90)$ & $(22.67)$ & $(23.13)$ \\
\hline r2 & 0.151 & 0.151 & 0.151 & 0.151 & 0.154 & 0.160 & 0.176 & 0.179 \\
\hline r2_a & 0.147 & 0.147 & 0.147 & 0.147 & 0.148 & 0.154 & 0.170 & 0.173 \\
\hline Aic & 22380 & 22381 & 22381 & 22380 & 22383 & 22368 & 22329 & 22325 \\
\hline $\mathrm{N}$ & 1993 & 1993 & 1993 & 1993 & 1993 & 1993 & 1993 & 1993 \\
\hline
\end{tabular}

$* \mathrm{p}<0.05, * * \mathrm{p}<0.01, * * * \mathrm{p}<0.001$

Fonte: Banco de Dados Matrículas e Gastos nos Municípios Brasileiros. 
A rede estadual e particular de ensino e a receita per capita média dos municípios apresentam sinais nas direções esperadas. São fatores que dependem menos de articulações dos prefeitos e estão mais relacionadas ao contexto no qual cada gestão local se insere. Desta forma, municípios com maior renda per capita tendem a criar mais vagas em creches, enquanto que municípios em que as redes estaduais e particulares crescem tendem a reduzir o tamanho das creches municipais.

Conforme o esperado, a demanda por vagas em creches apresenta relação estatisticamente significativa e positiva com a criação de vagas em creches municipais. O percentual da população local em idade ideal para frequentar creches tem uma relação com a criação de vagas contrária à esperada. Tudo mais constante, quanto maior a população em idade ideal para frequentar este nível de ensino, menor é a criação de novas vagas ${ }^{16}$.

As transferências do FUNDEF e do FUNDEB apresentam relação positiva com a expansão das creches municipais. Apesar de não estar de acordo com o esperado quando é lembrado que o FUNDEF foi um Fundo que recompensou estados e municípios apenas pelas matrículas realizadas no ensino fundamental, o capítulo 1 demonstrou que, mesmo durante o período de vigência do FUNDEF, a rede municipal de creches cresceu. Nenhuma diferença é apresentada entre os dois Fundos nas tabelas anteriores. Os coeficientes mostram que mesmo uma transferência média de $\mathrm{R} \$ 10.000,00$ a mais não resulta na criação de uma vaga em creche em nenhum dos períodos observados, sugerindo que, apesar de estatisticamente significativa, a transferência dos Fundos tem pouco reflexo na criação de vagas nas creches municipais.

O gasto do município com pessoal no último ano da gestão anterior afeta negativamente a expansão da rede municipal de creches apenas no último período observado. Apesar de não ser estatisticamente significativa nos demais períodos, a inclusão desta variável nos modelos de regressão impede que constrangimentos impostos ao prefeito devido a escolhas das gestões anteriores gerem viés na análise.

\footnotetext{
${ }^{16}$ O coeficiente desta variável é afetado pelas demais variáveis do modelo, pois em uma análise bivariada a relação desta variável com a criação de vagas é positiva.
} 
Os prefeitos não tendem a adaptar suas políticas de criação de vagas em creches quando houve crescimento no mandato anterior. Este comportamento indiferente sugere que, com a demanda mantida constante, não há uma compensação para os prefeitos manterem a política de expansão das matrículas em creches. O percentual das receitas estaduais destinadas pelos governadores à educação também não afetou a criação de vagas em creches.

Outras variáveis incluídas nos modelos para controlar pelo possível comportamento estratégico dos prefeitos não demonstraram os sinais esperados, ou são inconsistentes ao longo do tempo. Assim, o fato de um mesmo partido ter continuado no governo local só possui efeito estatisticamente significativo e na direção esperada no mandato dos prefeitos que vai de 2005 a 2008. Para este mandato, observa-se que os partidos que se mantiveram na prefeitura tenderam a criar 8,65 vagas a menos em seus municípios quando comparados com os municípios onde houve alternância, ou 8,14 vagas a menos quando controlamos por todas as outras variáveis que poderiam afetar a criação de vagas, com exceção das variáveis referentes ao partido dos prefeitos.

Algo semelhante ocorre no período que vai de 2000 a 2004 nos municípios em que o governo prévio havia sido do PT. Neste período, ter sido antecedido pelo PT significou uma redução de 18,54 vagas em média na criação de vagas nas creches municipais, ou 17,76 quando controla-se por todos os demais fatores dos modelos, com exceção do partido dos prefeitos. Entretanto, a falta de relação estatisticamente significativa entre os prefeitos do PT e o aumento de vagas não permite fazer inferências sobre o significado desta variável: o efeito de uma gestão prévia do PT pode tanto ser negativo porque o partido aumentou vagas em seu mandato terminado em 2000 e o prefeito seguinte, por não acreditar que isto Ihe traria algum retorno eleitoral positivo, não continuou suas políticas e manteve o mesmo número de vagas quando a tendência era de aumento; ou o PT não deu atenção às creches municipais, prejudicando seus sucessores que, então, teriam enfrentado dificuldades em promover o crescimento da sua rede municipal de creches. Ambos os cenários são possíveis, mas não há dados suficientes para confirmar nenhum dos dois. Mesmo estatísticas descritivas destas variáveis retornam valores que não tendem para nenhum dos dois lados. 
Com exceção do partido dos governadores, cujo efeito será explorado mais à frente, as demais variáveis não apresentam relação significativa com a criação de vagas nas creches da rede municipal de ensino.

\subsubsection{Criação de Vagas nas Pré-Escolas Municipais}

As pré-escolas municipais passaram por declínio importante durante o período que vai de 2000 a 2012. Um dos principais fatores para este declínio foi a implementação do ensino fundamental de 9 anos, que significou a diminuição de 1 ano da pré-escola e incorporação das crianças deste último ano no ensino fundamental. Assim, ao final do período, este nível de ensino era composto por apenas um ciclo de 2 anos. Somado a isto também ocorreu diminuição na população em idade ideal para frequentar este nível de ensino.

A seguir são apresentadas tabelas com os modelos de regressão utilizados para analisar a criação de vagas nas pré-escolas municipais. Devido às similaridades entre estes modelos e os modelos para a criação de vagas em creches municipais, apenas os pontos mais relevantes são destacados. 
Tabela 5.10: Modelos de Regressão para a Criação de Vagas em Pré-Escolas Municipais (2000 - 2004)

\begin{tabular}{|c|c|c|c|c|c|c|c|c|}
\hline & $\begin{array}{l}\text { Modelo } 1 \\
\text { b/se }\end{array}$ & $\begin{array}{c}\text { Modelo } 2 \\
\text { b/se }\end{array}$ & $\begin{array}{l}\text { Modelo } 3 \\
\text { b/se }\end{array}$ & $\begin{array}{c}\text { Modelo } 4 \\
\text { b/se }\end{array}$ & $\begin{array}{l}\text { Modelo } 5 \\
\text { b/se }\end{array}$ & $\begin{array}{c}\text { Modelo } 6 \\
\text { b/se }\end{array}$ & $\begin{array}{l}\text { Modelo } 7 \\
\text { b/se }\end{array}$ & $\begin{array}{c}\text { Modelo } 8 \\
\text { b/se }\end{array}$ \\
\hline \multirow[t]{2}{*}{ Pré-Escolas estaduais } & $-0.87^{* * *}$ & $-0.87^{* * *}$ & $-0.86^{* * *}$ & $-0.87^{* * *}$ & $-0.86^{* * *}$ & $-0.90^{* * *}$ & $-0.86^{* * *}$ & $-0.91^{* * *}$ \\
\hline & $(0.15)$ & $(0.15)$ & $(0.15)$ & $(0.15)$ & $(0.15)$ & $(0.15)$ & $(0.15)$ & $(0.15)$ \\
\hline \multirow[t]{2}{*}{ Pré-Escolas particulares } & -0.06 & -0.06 & -0.06 & -0.06 & -0.06 & -0.07 & -0.06 & -0.08 \\
\hline & $(0.12)$ & $(0.12)$ & $(0.12)$ & $(0.12)$ & $(0.12)$ & $(0.12)$ & $(0.12)$ & $(0.12)$ \\
\hline \multirow[t]{2}{*}{ L4.Demanda (\%) } & $1.77^{* * *}$ & $1.77^{* * *}$ & $1.77^{* * *}$ & $1.77^{* * *}$ & $1.76^{* * *}$ & $1.77^{* * *}$ & $1.76^{* * *}$ & $1.71^{* * *}$ \\
\hline & $(0.14)$ & $(0.14)$ & $(0.14)$ & $(0.14)$ & $(0.14)$ & $(0.14)$ & $(0.14)$ & $(0.14)$ \\
\hline \multirow[t]{2}{*}{ L4.Pop. idade ideal (\%) } & 0.34 & 0.20 & 0.25 & 0.20 & 0.77 & 1.59 & -0.03 & 2.90 \\
\hline & $(3.27)$ & $(3.30)$ & (3.29) & (3.29) & (3.33) & (3.34) & (3.37) & $(3.51)$ \\
\hline \multirow[t]{2}{*}{ Receita per capita média } & $2.04^{* * *}$ & $1.98^{* * *}$ & $2.03^{* * *}$ & $1.99^{* * *}$ & $2.01^{* * *}$ & $1.90^{* * *}$ & $2.02^{* * *}$ & $1.77^{* * *}$ \\
\hline & $(0.41)$ & $(0.41)$ & $(0.40)$ & $(0.40)$ & $(0.41)$ & $(0.41)$ & $(0.41)$ & $(0.41)$ \\
\hline \multirow[t]{2}{*}{ L4.Gasto com pessoal (\%) } & -0.55 & -0.49 & -0.50 & -0.49 & -0.56 & -0.57 & -0.50 & $-0.70^{*}$ \\
\hline & $(0.34)$ & $(0.34)$ & $(0.34)$ & $(0.34)$ & $(0.34)$ & $(0.34)$ & $(0.35)$ & $(0.35)$ \\
\hline \multirow{2}{*}{$\begin{array}{l}\text { Gasto médio (\%) dos governadores } \\
\text { em educação }\end{array}$} & $-2.40^{*}$ & $-2.49^{*}$ & $-2.37^{*}$ & $-2.51^{*}$ & -1.78 & $-4.12^{* *}$ & $-2.45^{*}$ & $-3.99^{* *}$ \\
\hline & $(1.13)$ & $(1.14)$ & (1.15) & $(1.14)$ & $(1.32)$ & $(1.38)$ & $(1.18)$ & $(1.46)$ \\
\hline \multirow{2}{*}{$\begin{array}{l}\text { Média de Transferências do } \\
\text { FUNDEF/FUNDEB }\end{array}$} & $0.00^{* * *}$ & $0.00^{* * *}$ & $0.00^{* * *}$ & $0.00^{* * *}$ & $0.00^{* * *}$ & $0.00^{* * *}$ & $0.00^{* * *}$ & $0.00^{* * *}$ \\
\hline & $(0.00)$ & $(0.00)$ & $(0.00)$ & $(0.00)$ & $(0.00)$ & $(0.00)$ & $(0.00)$ & $(0.00)$ \\
\hline \multirow[t]{2}{*}{ Continuidade } & -7.51 & & & & -7.71 & -6.83 & -7.86 & -7.33 \\
\hline & $(6.26)$ & & & & $(6.27)$ & $(6.26)$ & (6.29) & $(6.26)$ \\
\hline \multirow{2}{*}{$\begin{array}{l}\text { Distância entre eleito e segundo } \\
\text { mais votado }\end{array}$} & & 0.05 & & & 0.08 & 0.06 & 0.07 & 0.07 \\
\hline & & $(0.12)$ & & & $(0.12)$ & $(0.12)$ & $(0.12)$ & $(0.12)$ \\
\hline \multirow[t]{2}{*}{ Antecedido pelo PSDB } & & & -6.92 & & -6.25 & -11.63 & -7.14 & -11.66 \\
\hline & & & $(7.33)$ & & (7.44) & (7.59) & (7.36) & $(7.55)$ \\
\hline \multirow[t]{2}{*}{ Antecedido pelo PT } & & & & -20.91 & -20.75 & -21.28 & -21.61 & -22.80 \\
\hline & & & & $(20.19)$ & $(20.16)$ & $(20.42)$ & $(20.21)$ & $(20.17)$ \\
\hline \multirow[t]{2}{*}{ Governador do PMDB } & & & & & 7.95 & & & $21.64^{* *}$ \\
\hline & & & & & $(6.10)$ & & & $(7.66)$ \\
\hline \multirow[t]{2}{*}{ Governador do PSDB } & & & & & & $14.59^{* *}$ & & $22.59^{* * *}$ \\
\hline & & & & & & $(5.43)$ & & $(6.78)$ \\
\hline \multirow[t]{2}{*}{ Governador do PT } & & & & & & & 7.71 & $22.34^{*}$ \\
\hline & & & & & & & $(8.79)$ & $(10.02)$ \\
\hline \multirow[t]{2}{*}{ Constant } & -66.27 & -68.41 & -69.33 & -66.96 & $-80.91^{*}$ & -48.14 & -64.25 & -60.86 \\
\hline & (36.33) & (36.27) & (36.39) & (36.34) & (39.54) & (37.73) & (37.29) & $(40.58)$ \\
\hline$r 2$ & 0.185 & 0.185 & 0.185 & 0.185 & 0.186 & 0.190 & 0.186 & 0.194 \\
\hline r2_a & 0.182 & 0.181 & 0.181 & 0.181 & 0.181 & 0.185 & 0.181 & 0.188 \\
\hline Aic & 26192 & 26193 & 26192 & 26192 & 26197 & 26188 & 26198 & 26182 \\
\hline $\mathrm{N}$ & 2067 & 2067 & 2067 & 2067 & 2067 & 2067 & 2067 & 2067 \\
\hline
\end{tabular}

${ }^{*} \mathrm{p}<0.05,{ }^{* *} \mathrm{p}<0.01, * * * \mathrm{p}<0.001$

Fonte: Banco de Dados Matrículas e Gastos nos Municípios Brasileiros. 
Tabela 5.11: Modelos de Regressão para a Criação de Vagas em Pré-Escolas Municipais (2004 - 2008)

\begin{tabular}{|c|c|c|c|c|c|c|c|c|}
\hline & $\begin{array}{l}\text { Modelo } 1 \\
\text { b/se }\end{array}$ & $\begin{array}{c}\text { Modelo } 2 \\
\text { b/se }\end{array}$ & $\begin{array}{c}\text { Modelo } 3 \\
\text { b/se }\end{array}$ & $\begin{array}{c}\text { Modelo } 4 \\
\text { b/se }\end{array}$ & $\begin{array}{l}\text { Modelo } 5 \\
\text { b/se }\end{array}$ & $\begin{array}{c}\text { Modelo } 6 \\
\text { b/se }\end{array}$ & $\begin{array}{c}\text { Modelo } 7 \\
\text { b/se }\end{array}$ & $\begin{array}{c}\text { Modelo } 8 \\
\text { b/se }\end{array}$ \\
\hline \multirow[t]{2}{*}{ Pré-Escolas estaduais } & $-0.44^{* * *}$ & $-0.44^{* * *}$ & $-0.45^{* * *}$ & $-0.44^{* * *}$ & $-0.45^{* * *}$ & $-0.46^{* * *}$ & $-0.45^{* * *}$ & $-0.47^{* * *}$ \\
\hline & $(0.12)$ & $(0.12)$ & $(0.12)$ & $(0.12)$ & $(0.12)$ & $(0.12)$ & $(0.12)$ & $(0.12)$ \\
\hline \multirow[t]{2}{*}{ Pré-Escolas particulares } & 0.05 & 0.05 & 0.05 & 0.05 & 0.05 & 0.05 & 0.03 & 0.04 \\
\hline & $(0.10)$ & $(0.10)$ & $(0.10)$ & $(0.10)$ & $(0.10)$ & $(0.10)$ & $(0.10)$ & $(0.10)$ \\
\hline \multirow[t]{2}{*}{ L4.Demanda (\%) } & $2.82^{* * *}$ & $2.82^{* * *}$ & $2.82^{* * *}$ & $2.83^{* * *}$ & $2.83^{* * *}$ & $2.83^{* * *}$ & $2.88^{* * *}$ & $2.92^{* * *}$ \\
\hline & $(0.18)$ & $(0.18)$ & $(0.18)$ & $(0.18)$ & $(0.18)$ & $(0.18)$ & $(0.18)$ & $(0.18)$ \\
\hline \multirow[t]{2}{*}{ L4.Pop. idade ideal (\%) } & 0.51 & 0.67 & 0.56 & 0.50 & 0.22 & -1.83 & -1.05 & -3.11 \\
\hline & (3.23) & (3.24) & $(3.24)$ & $(3.23)$ & $(3.22)$ & $(3.17)$ & $(3.25)$ & $(3.16)$ \\
\hline \multirow[t]{2}{*}{ Receita per capita média } & $2.58^{* * *}$ & $2.54^{* * *}$ & $2.53^{* * *}$ & $2.53^{* * *}$ & $2.62^{* * *}$ & $2.54^{* * *}$ & $2.79^{* * *}$ & $2.71^{* * *}$ \\
\hline & $(0.33)$ & $(0.33)$ & $(0.34)$ & $(0.33)$ & $(0.34)$ & $(0.34)$ & $(0.34)$ & $(0.34)$ \\
\hline \multirow[t]{2}{*}{ L4.Gasto com pessoal (\%) } & $1.04^{* *}$ & $1.08^{* *}$ & $1.04^{* *}$ & $1.07^{* *}$ & $0.94^{*}$ & $1.31^{* *}$ & $1.18^{* *}$ & $1.39^{* * *}$ \\
\hline & $(0.39)$ & $(0.39)$ & $(0.39)$ & $(0.39)$ & (0.39) & $(0.40)$ & $(0.39)$ & $(0.40)$ \\
\hline \multirow{2}{*}{$\begin{array}{l}\text { Gasto médio (\%) dos governadores } \\
\text { em educação }\end{array}$} & $-3.23^{* *}$ & $-3.19^{* *}$ & $-3.38^{* *}$ & $-3.24^{* *}$ & $-2.80^{*}$ & $-4.84^{* * *}$ & $-3.05^{* *}$ & $-3.40^{* *}$ \\
\hline & $(1.03)$ & $(1.03)$ & $(1.03)$ & $(1.03)$ & $(1.19)$ & (1.19) & $(1.01)$ & $(1.23)$ \\
\hline \multirow{4}{*}{$\begin{array}{l}\text { Média de Transferências do } \\
\text { FUNDEF/FUNDEB } \\
\text { L4.Crescimento das pré-escolas } \\
\text { municipais }\end{array}$} & $-0.00^{* *}$ & $-0.00^{* *}$ & $-0.00^{* *}$ & $-0.00^{* *}$ & $-0.00^{* *}$ & $-0.00^{* *}$ & $-0.00^{* *}$ & $-0.00^{* * *}$ \\
\hline & $(0.00)$ & $(0.00)$ & $(0.00)$ & $(0.00)$ & $(0.00)$ & $(0.00)$ & $(0.00)$ & $(0.00)$ \\
\hline & 3.49 & 2.83 & 2.87 & 3.07 & 4.20 & -0.42 & 3.31 & -0.59 \\
\hline & $(5.42)$ & $(5.45)$ & $(5.43)$ & $(5.44)$ & $(5.45)$ & $(5.52)$ & $(5.41)$ & $(5.53)$ \\
\hline \multirow[t]{2}{*}{ Continuidade } & $-14.94^{*}$ & & & & $-15.36^{*}$ & $-14.98^{*}$ & $-16.97^{* *}$ & $-15.93^{*}$ \\
\hline & $(6.18)$ & & & & $(6.20)$ & $(6.18)$ & $(6.22)$ & $(6.21)$ \\
\hline \multirow{2}{*}{$\begin{array}{l}\text { Distância entre eleito e segundo } \\
\text { mais votado }\end{array}$} & & -0.02 & & & -0.02 & 0.01 & -0.01 & 0.01 \\
\hline & & $(0.12)$ & & & $(0.12)$ & $(0.12)$ & $(0.12)$ & $(0.12)$ \\
\hline \multirow[t]{2}{*}{ Antecedido pelo PSDB } & & & $16.89^{*}$ & & $16.40^{*}$ & $17.97^{*}$ & $17.96^{*}$ & $16.25^{*}$ \\
\hline & & & $(6.98)$ & & (7.01) & $(7.02)$ & $(7.02)$ & $(7.00)$ \\
\hline \multirow[t]{2}{*}{ Antecedido pelo PT } & & & & -24.44 & -18.31 & -16.48 & -15.43 & -13.32 \\
\hline & & & & $(15.78)$ & $(15.65)$ & $(15.86)$ & $(15.75)$ & $(16.04)$ \\
\hline \multirow[t]{2}{*}{ Governador do PMDB } & & & & & -6.54 & & & $-14.46^{* *}$ \\
\hline & & & & & (4.19) & & & $(4.89)$ \\
\hline \multirow[t]{2}{*}{ Governador do PSDB } & & & & & & $-15.14^{* * *}$ & & $-17.95^{* * *}$ \\
\hline & & & & & & $(3.88)$ & & $(4.59)$ \\
\hline \multirow[t]{2}{*}{ Governador do PT } & & & & & & & $24.94^{* *}$ & 12.46 \\
\hline & & & & & & & $(8.16)$ & $(8.87)$ \\
\hline \multirow[t]{2}{*}{ Constant } & $-198.32^{* * *}$ & $-205.30^{* * *}$ & $-202.33^{* * *}$ & $-203.05^{* * *}$ & $-199.98^{* * *}$ & $-156.79^{* * *}$ & $-208.26^{* * *}$ & $-173.13^{* * *}$ \\
\hline & (34.57) & $(34.40)$ & $(34.33)$ & $(34.23)$ & $(34.90)$ & $(36.43)$ & (34.29) & $(36.46)$ \\
\hline$r 2$ & 0.237 & 0.235 & 0.237 & 0.236 & 0.240 & 0.245 & 0.244 & 0.250 \\
\hline r2_a & 0.233 & 0.231 & 0.233 & 0.232 & 0.235 & 0.240 & 0.239 & 0.244 \\
\hline aic & 25931 & 25937 & 25931 & 25935 & 25930 & 25917 & 25920 & 25907 \\
\hline $\mathrm{N}$ & 2067 & 2067 & 2067 & 2067 & 2067 & 2067 & 2067 & 2067 \\
\hline
\end{tabular}

$* \mathrm{p}<0.05, * * \mathrm{p}<0.01, * * * \mathrm{p}<0.001$

Fonte: Banco de Dados Matrículas e Gastos nos Municípios Brasileiros. 
Tabela 5.12: Modelos de Regressão para a Criação de Vagas em Pré-Escolas Municipais (2008 - 2012)

\begin{tabular}{|c|c|c|c|c|c|c|c|c|}
\hline & $\begin{array}{l}\text { Modelo } 1 \\
\text { b/se }\end{array}$ & $\begin{array}{c}\text { Modelo } 2 \\
\text { b/se }\end{array}$ & $\begin{array}{l}\text { Modelo } 3 \\
\text { b/se }\end{array}$ & $\begin{array}{c}\text { Modelo } 4 \\
\text { b/se }\end{array}$ & $\begin{array}{c}\text { Modelo } 5 \\
\text { b/se }\end{array}$ & $\begin{array}{c}\text { Modelo } 6 \\
\text { b/se }\end{array}$ & $\begin{array}{c}\text { Modelo } 7 \\
\text { b/se }\end{array}$ & $\begin{array}{c}\text { Modelo } 8 \\
\text { b/se }\end{array}$ \\
\hline \multirow[t]{2}{*}{ Pré-Escolas estaduais } & $-0.94^{* * *}$ & $-0.94^{* * *}$ & $-0.94^{* * *}$ & $-0.94^{* * *}$ & $-0.94^{* * *}$ & $-0.96^{* * *}$ & $-0.96^{* * *}$ & $-0.96^{* * *}$ \\
\hline & $(0.10)$ & $(0.10)$ & $(0.10)$ & $(0.10)$ & $(0.10)$ & $(0.10)$ & $(0.10)$ & $(0.10)$ \\
\hline \multirow[t]{2}{*}{ Pré-Escolas particulares } & $-0.46^{* * *}$ & $-0.46^{* * *}$ & $-0.46^{* * *}$ & $-0.46^{* * *}$ & $-0.46^{* * *}$ & $-0.46^{* * *}$ & $-0.46^{* * *}$ & $-0.46^{* * *}$ \\
\hline & $(0.11)$ & $(0.11)$ & $(0.11)$ & $(0.11)$ & $(0.11)$ & $(0.11)$ & $(0.11)$ & $(0.11)$ \\
\hline \multirow[t]{2}{*}{ L4.Demanda (\%) } & $3.65^{* * *}$ & $3.65^{* * *}$ & $3.65^{* * *}$ & $3.64^{* * *}$ & $3.64^{* * *}$ & $3.66^{* * *}$ & $3.65^{* * *}$ & $3.65^{* * *}$ \\
\hline & $(0.18)$ & $(0.18)$ & $(0.18)$ & $(0.18)$ & $(0.17)$ & $(0.18)$ & $(0.17)$ & $(0.17)$ \\
\hline \multirow[t]{2}{*}{ L4.Pop. idade ideal (\%) } & $-23.06^{* * *}$ & $-22.94^{* * *}$ & $-22.99^{* * *}$ & $-22.81^{* * *}$ & $-22.67^{* * *}$ & $-21.85^{* * *}$ & $-23.40^{* * *}$ & $-22.86^{* * *}$ \\
\hline & $(3.77)$ & $(3.81)$ & (3.79) & $(3.80)$ & $(3.81)$ & $(3.72)$ & $(3.86)$ & (3.82) \\
\hline \multirow[t]{2}{*}{ Receita per capita média } & $1.34^{* * *}$ & $1.35^{* * *}$ & $1.34^{* * *}$ & $1.34^{* * *}$ & $1.37^{* * *}$ & $1.33^{* * *}$ & $1.31^{* * *}$ & $1.34^{* * *}$ \\
\hline & $(0.26)$ & $(0.26)$ & $(0.26)$ & $(0.26)$ & $(0.26)$ & $(0.26)$ & $(0.25)$ & $(0.26)$ \\
\hline \multirow[t]{2}{*}{ L4.Gasto com pessoal (\%) } & -0.31 & -0.31 & -0.31 & -0.29 & -0.31 & -0.27 & -0.29 & -0.31 \\
\hline & $(0.37)$ & $(0.37)$ & $(0.37)$ & $(0.38)$ & $(0.38)$ & $(0.37)$ & $(0.37)$ & $(0.38)$ \\
\hline \multirow{2}{*}{$\begin{array}{l}\text { Gasto médio (\%) dos governadores } \\
\text { em educação }\end{array}$} & 0.58 & 0.59 & 0.58 & 0.62 & 0.60 & 0.60 & 0.27 & 0.21 \\
\hline & $(0.56)$ & $(0.56)$ & $(0.56)$ & $(0.56)$ & $(0.57)$ & $(0.56)$ & $(0.56)$ & $(0.56)$ \\
\hline \multirow{2}{*}{$\begin{array}{l}\text { Média de Transferências do } \\
\text { FUNDEF/FUNDEB }\end{array}$} & -0.00 & -0.00 & -0.00 & -0.00 & -0.00 & -0.00 & -0.00 & -0.00 \\
\hline & $(0.00)$ & $(0.00)$ & $(0.00)$ & $(0.00)$ & $(0.00)$ & $(0.00)$ & $(0.00)$ & $(0.00)$ \\
\hline \multirow{2}{*}{$\begin{array}{l}\text { L4.Crescimento das pré-escolas } \\
\text { municipais }\end{array}$} & -5.47 & -5.49 & -5.46 & -5.64 & -5.68 & -5.72 & -5.51 & -5.44 \\
\hline & $(4.58)$ & (4.59) & $(4.58)$ & $(4.60)$ & (4.63) & $(4.61)$ & $(4.59)$ & $(4.61)$ \\
\hline \multirow[t]{2}{*}{ Continuidade } & -1.16 & & & & -1.43 & -1.33 & -1.80 & -1.94 \\
\hline & $(4.24)$ & & & & $(4.31)$ & (4.31) & $(4.26)$ & (4.29) \\
\hline \multirow{2}{*}{$\begin{array}{l}\text { Distância entre eleito e segundo } \\
\text { mais votado }\end{array}$} & & -0.05 & & & -0.04 & -0.05 & -0.05 & -0.05 \\
\hline & & $(0.10)$ & & & $(0.10)$ & $(0.10)$ & $(0.10)$ & $(0.10)$ \\
\hline \multirow[t]{2}{*}{ Antecedido pelo PSDB } & & & 1.04 & & 1.70 & -0.54 & -1.64 & -2.23 \\
\hline & & & (6.16) & & (6.14) & (6.19) & (6.18) & (6.14) \\
\hline \multirow[t]{2}{*}{ Antecedido pelo PT } & & & & 9.83 & 10.48 & 9.38 & 9.11 & 9.25 \\
\hline & & & & $(7.77)$ & (7.93) & $(7.93)$ & $(8.11)$ & $(8.17)$ \\
\hline \multirow[t]{2}{*}{ Governador do PMDB } & & & & & -1.40 & & & -5.41 \\
\hline & & & & & (7.93) & & & $(8.03)$ \\
\hline \multirow[t]{2}{*}{ Governador do PSDB } & & & & & & 6.75 & & 0.70 \\
\hline & & & & & & (3.45) & & $(3.73)$ \\
\hline \multirow[t]{2}{*}{ Governador do PT } & & & & & & & $-19.52^{* * *}$ & $-19.79^{* *}$ \\
\hline & & & & & & & $(5.69)$ & $(6.07)$ \\
\hline \multirow[t]{2}{*}{ Constant } & $-137.91^{* * *}$ & $-138.01^{* * *}$ & $-138.77^{* * *}$ & $-140.86^{* * *}$ & $-139.51^{* * *}$ & $-148.13^{* * *}$ & $-129.96^{* * *}$ & $-130.94^{* * *}$ \\
\hline & (26.48) & $(26.60)$ & $(26.58)$ & (26.74) & $(26.62)$ & (26.95) & (26.69) & (27.10) \\
\hline r2 & 0.358 & 0.358 & 0.358 & 0.358 & 0.359 & 0.360 & 0.366 & 0.366 \\
\hline$r_{2} a$ & 0.355 & 0.355 & 0.355 & 0.355 & 0.354 & 0.356 & 0.361 & 0.361 \\
\hline aic & 24856 & 24856 & 24856 & 24855 & 24862 & 24858 & 24839 & 24842 \\
\hline $\mathrm{N}$ & 2067 & 2067 & 2067 & 2067 & 2067 & 2067 & 2067 & 2067 \\
\hline
\end{tabular}

${ }^{*} p<0.05, * * p<0.01, * * * p<0.001$

Fonte: Banco de Dados Matrículas e Gastos nos Municípios Brasileiros. 
Contrariamente ao esperado, o FUNDEB apresentou relação negativa com o tamanho da rede municipal de pré-escolas. No primeiro período (2000-2004), o município que recebeu receitas do FUNDEF mostrou tendência de aumento em suas matrículas nas pré-escolas municipais, mas no período posterior, quando passou a vigorar o FUNDEB, este Fundo passou estar negativamente associado à expansão dessas matrículas. Por fim, no período de 2008-2012, as transferências do Fundo não apresentam associação com a expansão das matrículas em pré-escolas municipais. O efeito estimado das transferências dos Fundos sobre a criação de vagas em pré-escolas é bastante similar ao efeito estimado no caso das creches: apesar de haver uma relação estatisticamente significativa entre as transferências e a expansão das matrículas, a relação é pequena o suficiente a ponto de uma transferência de $\mathrm{R} \$ 10.000,00$ não se associar à criação de uma vaga a mais nestes níveis de ensino.

Semelhantemente ao ocorrido com as creches municipais, para as pré-escolas municipais a continuidade do mesmo partido na prefeitura no período que vai de 2004 a 2008 teve efeito negativo e estatisticamente significativo, mas isto só é observável neste período.

No período que vai de 2004 a 2008, os municípios em que o PSDB foi governo na gestão anterior tendem a apresentar maior crescimento na rede municipal de pré escolas que nos demais municípios. Entretanto, esta relação também só está presente neste período e traz os mesmos problemas do governo atual ser antecedido pelo PT na análise da criação de vagas em creches no período de 2000 a 2004.

\subsubsection{Criação de Vagas no Ensino Fundamental Municipal}

Diferentemente dos demais níveis de ensino, o acesso ao ensino fundamental está universalizado (AGUIAR, 2010; CAMPOS; CRUZ, 2009). Esta situação peculiar faz com que o ensino fundamental esteja em uma situação diferente dos demais níveis de ensino. No longo prazo, suas matrículas tenderam a convergir para a população em idade ideal e o aumento da rede municipal de ensino fundamental depende mais de articulações entre os governos municipais e estaduais sobre qual rede deveria ofertar tal serviço do que da necessidade de criar novas escolas para atender à demanda local. 
As tabelas a seguir expõem os modelos de regressão utilizados para estimar a criação de vagas no ensino fundamental municipal:

Tabela 5.13: Modelos de Regressão para a Criação de Vagas no Ensino Fundamental Municipal (2000 - 2004)

Modelo 1 Modelo 2 Modelo 3 Modelo 4 Modelo 5 Modelo 6 Modelo 7 Modelo 8

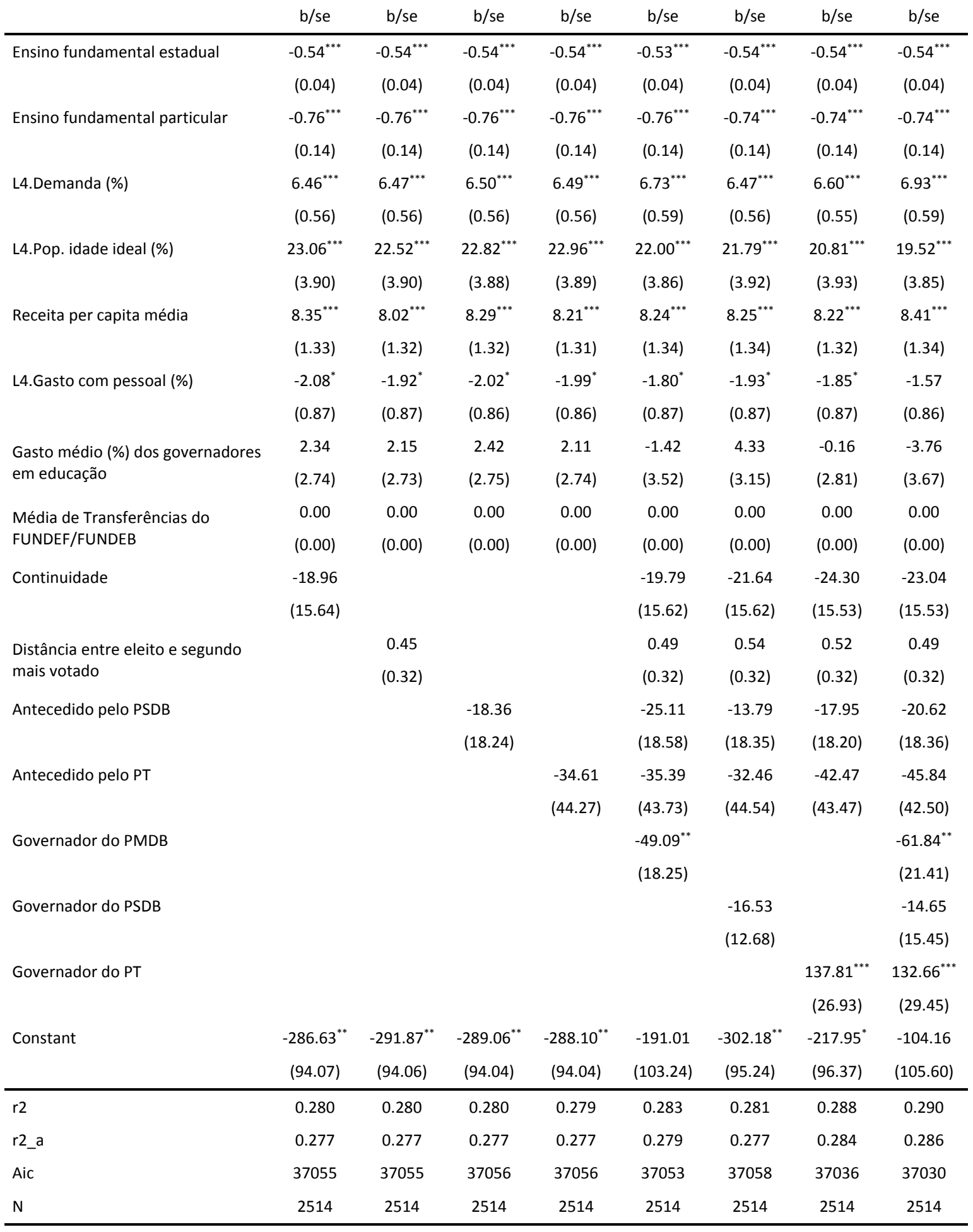

$* \mathrm{p}<0.05, * * \mathrm{p}<0.01, * * * \mathrm{p}<0.001$

Fonte: Banco de Dados Matrículas e Gastos nos Municípios Brasileiros. 
Tabela 5.14: Modelos de Regressão para a Criação de Vagas no Ensino Fundamental Municipal (2004 - 2008)

\begin{tabular}{|c|c|c|c|c|c|c|c|c|}
\hline & $\begin{array}{l}\text { Modelo } 1 \\
\text { b/se }\end{array}$ & $\begin{array}{c}\text { Modelo } 2 \\
\text { b/se }\end{array}$ & $\begin{array}{c}\text { Modelo } 3 \\
\text { b/se }\end{array}$ & $\begin{array}{c}\text { Modelo } 4 \\
\text { b/se }\end{array}$ & $\begin{array}{c}\text { Modelo } 5 \\
\text { b/se }\end{array}$ & $\begin{array}{c}\text { Modelo } 6 \\
\text { b/se }\end{array}$ & $\begin{array}{l}\text { Modelo } 7 \\
\text { b/se }\end{array}$ & $\begin{array}{c}\text { Modelo } 8 \\
\text { b/se }\end{array}$ \\
\hline \multirow[t]{2}{*}{ Ensino fundamental estadual } & $-0.51^{* * *}$ & $-0.51^{* * *}$ & $-0.51^{* * *}$ & $-0.51^{* * *}$ & $-0.52^{* * *}$ & $-0.51^{* * *}$ & $-0.50^{* * *}$ & $-0.51^{* * *}$ \\
\hline & $(0.06)$ & $(0.06)$ & $(0.06)$ & $(0.06)$ & $(0.06)$ & $(0.06)$ & $(0.06)$ & $(0.06)$ \\
\hline \multirow[t]{2}{*}{ Ensino fundamental particular } & -0.14 & -0.14 & -0.14 & -0.14 & -0.16 & -0.17 & -0.14 & -0.21 \\
\hline & $(0.19)$ & $(0.19)$ & $(0.19)$ & $(0.19)$ & $(0.19)$ & $(0.19)$ & $(0.19)$ & $(0.19)$ \\
\hline \multirow[t]{2}{*}{ L4.Demanda (\%) } & $7.60^{* * *}$ & $7.61^{* * *}$ & $7.60^{* * *}$ & $7.60^{* * *}$ & $7.51^{* * *}$ & $7.53^{* * *}$ & $7.21^{* * *}$ & $7.10^{* * *}$ \\
\hline & $(0.55)$ & $(0.55)$ & $(0.55)$ & $(0.55)$ & $(0.56)$ & $(0.55)$ & $(0.55)$ & $(0.56)$ \\
\hline \multirow[t]{2}{*}{ L4.Pop. idade ideal (\%) } & $-19.49^{* * *}$ & $-19.82^{* * *}$ & $-19.37^{* * *}$ & $-19.48^{* * *}$ & $-19.58^{* * *}$ & $-17.86^{* * *}$ & $-17.69^{* * *}$ & $-16.19^{* * *}$ \\
\hline & $(3.94)$ & $(3.95)$ & $(3.94)$ & $(3.94)$ & (3.97) & $(3.94)$ & $(3.97)$ & (3.96) \\
\hline \multirow[t]{2}{*}{ Receita per capita média } & $12.36^{* * *}$ & $12.14^{* * *}$ & $12.37^{* * *}$ & $12.33^{* * *}$ & $12.05^{* * *}$ & $12.31^{* * *}$ & $11.44^{* * *}$ & $11.53^{* * *}$ \\
\hline & $(1.24)$ & $(1.24)$ & $(1.24)$ & $(1.24)$ & $(1.22)$ & $(1.25)$ & $(1.23)$ & $(1.23)$ \\
\hline \multirow[t]{2}{*}{ L4.Gasto com pessoal (\%) } & 0.72 & 0.80 & 0.69 & 0.76 & 0.84 & -0.13 & -0.00 & -0.50 \\
\hline & (1.11) & $(1.11)$ & (1.11) & $(1.11)$ & $(1.11)$ & (1.16) & (1.14) & (1.17) \\
\hline \multirow{2}{*}{$\begin{array}{l}\text { Gasto médio (\%) dos governadores } \\
\text { em educação }\end{array}$} & $6.12^{*}$ & $6.04^{*}$ & $5.62^{*}$ & $6.15^{*}$ & 2.69 & $9.34^{* *}$ & 4.74 & 4.68 \\
\hline & (2.57) & $(2.57)$ & $(2.60)$ & (2.57) & $(3.18)$ & $(3.07)$ & (2.59) & $(3.32)$ \\
\hline \multirow{2}{*}{$\begin{array}{l}\text { Média de Transferências do } \\
\text { FUNDEF/FUNDEB }\end{array}$} & $-0.00^{* * *}$ & $-0.00^{* * *}$ & $-0.00^{* * *}$ & $-0.00^{* * *}$ & $-0.00^{* * *}$ & $-0.00^{* * *}$ & $-0.00^{* * *}$ & $-0.00^{* * *}$ \\
\hline & $(0.00)$ & $(0.00)$ & $(0.00)$ & $(0.00)$ & $(0.00)$ & $(0.00)$ & $(0.00)$ & $(0.00)$ \\
\hline \multirow{2}{*}{$\begin{array}{l}\text { L4.Crescimento do ensino } \\
\text { fundamental municipal }\end{array}$} & $79.42^{* * *}$ & $78.84^{* * *}$ & $78.77^{* * *}$ & $79.12^{* * *}$ & $79.97^{* * *}$ & $78.89^{* * *}$ & $76.15^{* * *}$ & $79.30^{* * *}$ \\
\hline & $(16.20)$ & (16.24) & (16.18) & $(16.23)$ & $(16.18)$ & (16.16) & (16.13) & (16.15) \\
\hline \multirow[t]{2}{*}{ Continuidade } & -8.32 & & & & -11.49 & -11.05 & -4.87 & -5.21 \\
\hline & (16.33) & & & & $(16.38)$ & (16.32) & $(16.34)$ & $(16.26)$ \\
\hline \multirow{2}{*}{$\begin{array}{l}\text { Distância entre eleito e segundo } \\
\text { mais votado }\end{array}$} & & 0.73 & & & 0.75 & 0.71 & 0.72 & 0.70 \\
\hline & & $(0.38)$ & & & $(0.38)$ & $(0.38)$ & $(0.38)$ & $(0.38)$ \\
\hline \multirow[t]{2}{*}{ Antecedido pelo PSDB } & & & 37.66 & & $43.23^{*}$ & 38.08 & 37.40 & $44.21^{*}$ \\
\hline & & & (19.84) & & (20.16) & (20.01) & (20.01) & (20.13) \\
\hline \multirow[t]{2}{*}{ Antecedido pelo PT } & & & & 7.59 & 16.46 & 12.93 & 8.07 & 3.13 \\
\hline & & & & (39.99) & $(40.55)$ & (39.55) & $(40.34)$ & (40.19) \\
\hline \multirow[t]{2}{*}{ Governador do PMDB } & & & & & $30.89^{*}$ & & & $48.53^{* * *}$ \\
\hline & & & & & (12.21) & & & $(13.41)$ \\
\hline \multirow[t]{2}{*}{ Governador do PSDB } & & & & & & $39.02^{* * *}$ & & $42.67^{* * *}$ \\
\hline & & & & & & $(9.56)$ & & $(10.91)$ \\
\hline \multirow[t]{2}{*}{ Governador do PT } & & & & & & & $-89.00^{* * *}$ & $-60.86^{*}$ \\
\hline & & & & & & & $(22.93)$ & (23.93) \\
\hline \multirow[t]{2}{*}{ Constant } & 41.75 & 34.77 & 40.03 & 37.54 & 61.68 & -55.31 & 63.05 & -11.72 \\
\hline & $(104.04)$ & $(104.05)$ & $(104.22)$ & $(104.30)$ & $(106.45)$ & (109.35) & $(105.15)$ & $(110.40)$ \\
\hline r2 & 0.333 & 0.334 & 0.334 & 0.333 & 0.336 & 0.339 & 0.341 & 0.345 \\
\hline r2_a & 0.331 & 0.331 & 0.332 & 0.331 & 0.333 & 0.335 & 0.337 & 0.341 \\
\hline Aic & 37206 & 37204 & 37203 & 37206 & 37203 & 37194 & 37185 & 37173 \\
\hline$N$ & 2514 & 2514 & 2514 & 2514 & 2514 & 2514 & 2514 & 2514 \\
\hline
\end{tabular}

$* p<0.05, * * p<0.01, * * * p<0.001$

Fonte: Banco de Dados Matrículas e Gastos nos Municípios Brasileiros. 
Tabela 5.15: Modelos de Regressão para a Criação de Vagas no Ensino Fundamental Municipal (2008 - 2012)

\begin{tabular}{|c|c|c|c|c|c|c|c|c|}
\hline & $\begin{array}{l}\text { Modelo } 1 \\
\text { b/se }\end{array}$ & $\begin{array}{c}\text { Modelo } 2 \\
\text { b/se }\end{array}$ & $\begin{array}{c}\text { Modelo } 3 \\
\text { b/se }\end{array}$ & $\begin{array}{c}\text { Modelo } 4 \\
\text { b/se }\end{array}$ & $\begin{array}{c}\text { Modelo } 5 \\
\text { b/se }\end{array}$ & $\begin{array}{c}\text { Modelo } 6 \\
\text { b/se }\end{array}$ & $\begin{array}{l}\text { Modelo } 7 \\
\text { b/se }\end{array}$ & $\begin{array}{c}\text { Modelo } 8 \\
\text { b/se }\end{array}$ \\
\hline \multirow[t]{2}{*}{ Ensino fundamental estadual } & $-0.59^{* * *}$ & $-0.59^{* * *}$ & $-0.59^{* * *}$ & $-0.59^{* * *}$ & $-0.59^{* * *}$ & $-0.59^{* * *}$ & $-0.58^{* * *}$ & $-0.58^{* * *}$ \\
\hline & $(0.06)$ & $(0.06)$ & $(0.06)$ & $(0.06)$ & $(0.06)$ & $(0.06)$ & $(0.06)$ & $(0.06)$ \\
\hline \multirow[t]{2}{*}{ Ensino fundamental particular } & $-0.41^{* *}$ & $-0.41^{* *}$ & $-0.41^{* *}$ & $-0.41^{* *}$ & $-0.41^{* *}$ & $-0.42^{* *}$ & $-0.40^{* *}$ & $-0.40^{* *}$ \\
\hline & $(0.13)$ & $(0.13)$ & $(0.13)$ & $(0.13)$ & $(0.13)$ & $(0.13)$ & $(0.13)$ & $(0.13)$ \\
\hline \multirow[t]{2}{*}{ L4.Demanda (\%) } & $5.42^{* * *}$ & $5.41^{* * *}$ & $5.41^{* * *}$ & $5.42^{* * *}$ & $5.39^{* * *}$ & $5.37^{* * *}$ & $5.30^{* * *}$ & $5.28^{* * *}$ \\
\hline & $(0.56)$ & $(0.56)$ & $(0.56)$ & $(0.56)$ & $(0.56)$ & $(0.55)$ & $(0.55)$ & $(0.55)$ \\
\hline \multirow[t]{2}{*}{ L4.Pop. idade ideal (\%) } & 0.11 & 0.20 & 0.17 & 0.09 & -0.54 & 1.13 & -0.87 & -0.65 \\
\hline & (2.99) & $(3.00)$ & (2.99) & (2.99) & (3.03) & (2.99) & $(3.00)$ & $(3.01)$ \\
\hline \multirow[t]{2}{*}{ Receita per capita média } & $7.28^{* * *}$ & $7.33^{* * *}$ & $7.29^{* * *}$ & $7.26^{* * *}$ & $7.10^{* * *}$ & $7.21^{* * *}$ & $7.09^{* * *}$ & $6.84^{* * *}$ \\
\hline & $(0.78)$ & $(0.78)$ & $(0.78)$ & $(0.77)$ & $(0.79)$ & $(0.78)$ & $(0.77)$ & $(0.78)$ \\
\hline \multirow[t]{2}{*}{ L4.Gasto com pessoal (\%) } & -1.12 & -1.14 & -1.11 & -1.15 & -1.08 & -1.16 & -1.29 & -1.13 \\
\hline & $(0.75)$ & $(0.75)$ & $(0.74)$ & $(0.75)$ & $(0.75)$ & $(0.75)$ & $(0.75)$ & $(0.75)$ \\
\hline \multirow{2}{*}{$\begin{array}{l}\text { Gasto médio (\%) dos governadores } \\
\text { em educação }\end{array}$} & -1.79 & -1.78 & -1.91 & -1.90 & -1.69 & -1.95 & $-2.88^{*}$ & -2.35 \\
\hline & $(1.30)$ & $(1.30)$ & $(1.29)$ & $(1.31)$ & $(1.31)$ & $(1.31)$ & $(1.29)$ & $(1.32)$ \\
\hline \multirow{2}{*}{$\begin{array}{l}\text { Média de Transferências do } \\
\text { FUNDEF/FUNDEB }\end{array}$} & $-0.00^{* * *}$ & $-0.00^{* * *}$ & $-0.00^{* * *}$ & $-0.00^{* * *}$ & $-0.00^{* * *}$ & $-0.00^{* * *}$ & $-0.00^{* * *}$ & $-0.00^{* * *}$ \\
\hline & $(0.00)$ & $(0.00)$ & $(0.00)$ & $(0.00)$ & $(0.00)$ & $(0.00)$ & $(0.00)$ & $(0.00)$ \\
\hline \multirow{2}{*}{$\begin{array}{l}\text { L4.Crescimento do ensino } \\
\text { fundamental municipal }\end{array}$} & $87.47^{* * *}$ & $87.71^{* * *}$ & $87.09^{* * *}$ & $88.03^{* * *}$ & $87.16^{* * *}$ & $84.26^{* * *}$ & $83.75^{* * *}$ & $80.95^{* * *}$ \\
\hline & (11.61) & $(11.60)$ & $(11.59)$ & $(11.66)$ & $(11.62)$ & (11.59) & $(11.63)$ & $(11.56)$ \\
\hline \multirow[t]{2}{*}{ Continuidade } & -2.25 & & & & 1.49 & 0.94 & -1.48 & 0.31 \\
\hline & $(10.31)$ & & & & $(10.53)$ & (10.49) & $(10.44)$ & (10.48) \\
\hline \multirow{2}{*}{$\begin{array}{l}\text { Distância entre eleito e segundo } \\
\text { mais votado }\end{array}$} & & -0.24 & & & -0.25 & -0.24 & -0.26 & -0.28 \\
\hline & & $(0.24)$ & & & $(0.24)$ & $(0.24)$ & $(0.24)$ & $(0.24)$ \\
\hline \multirow[t]{2}{*}{ Antecedido pelo PSDB } & & & 12.57 & & 12.30 & 4.71 & 3.90 & 2.81 \\
\hline & & & $(14.17)$ & & $(14.16)$ & $(14.12)$ & $(14.12)$ & $(14.06)$ \\
\hline \multirow[t]{2}{*}{ Antecedido pelo PT } & & & & -25.01 & -24.67 & -26.25 & -24.52 & -27.73 \\
\hline & & & & $(20.40)$ & $(20.37)$ & $(20.57)$ & (20.89) & $(20.85)$ \\
\hline \multirow[t]{2}{*}{ Governador do PMDB } & & & & & 31.91 & & & 31.57 \\
\hline & & & & & $(16.45)$ & & & $(17.07)$ \\
\hline \multirow[t]{2}{*}{ Governador do PSDB } & & & & & & $19.69^{* *}$ & & 15.11 \\
\hline & & & & & & (7.39) & & $(8.20)$ \\
\hline \multirow[t]{2}{*}{ Governador do PT } & & & & & & & $-37.64^{* *}$ & $-28.82^{*}$ \\
\hline & & & & & & & $(12.52)$ & $(13.66)$ \\
\hline \multirow[t]{2}{*}{ Constant } & -50.27 & -48.18 & -53.37 & -46.20 & -38.72 & -69.48 & -0.15 & -23.77 \\
\hline & (61.69) & $(61.88)$ & $(62.37)$ & $(62.15)$ & $(62.25)$ & (63.19) & (62.49) & $(64.12)$ \\
\hline r2 & 0.373 & 0.373 & 0.373 & 0.373 & 0.375 & 0.375 & 0.378 & 0.380 \\
\hline$r_{2} a^{a}$ & 0.371 & 0.371 & 0.371 & 0.371 & 0.372 & 0.372 & 0.375 & 0.376 \\
\hline aic & 35046 & 35045 & 35045 & 35044 & 35046 & 35044 & 35033 & 35031 \\
\hline $\mathrm{N}$ & 2514 & 2514 & 2514 & 2514 & 2514 & 2514 & 2514 & 2514 \\
\hline
\end{tabular}

$* p<0.05, * * p<0.01, * * * p<0.001$

Fonte: Banco de Dados Matrículas e Gastos nos Municípios Brasileiros. 
O ponto mais importante nos modelos utilizados para analisar o ensino fundamental é que o crescimento das matrículas no ensino fundamental municipal no mandato anterior está positivamente associado à expansão das matrículas nos períodos de 2004 a 2008 e de 2008 a 2012. Isto mostra o efeito inercial do crescimento da rede municipal de ensino fundamental uma vez que ela já tenha aumentado no período anterior. Ainda assim, o fato de o crescimento prévio da rede municipal de ensino ser estatisticamente significativo apenas nos modelos para o ensino fundamental evidencia como a dinâmica de criação de vagas varia mesmo entre diferentes níveis de ensino. Como foi visto no capítulo 1, o ensino fundamental é o nível de ensino em que os governos estaduais ainda apresentam presença importante, apesar de decrescente. Sabe-se, também, que o aumento da rede municipal de ensino fundamental é fortemente influenciado pelas escolhas feitas pelos governos estaduais (ARRETCHE, 2000; GOMES, 2009). Isto sugere que a influência que o crescimento prévio do ensino fundamental municipal tem sobre o crescimento presente se relaciona às parcerias e acordos feitos entre governo estadual e governo municipal. A necessidade de manter o acordo, ou o tempo necessário para rompê-lo seria traduzido nesta relação positiva entre crescimento prévio e crescimento presente da rede municipal de ensino fundamental.

No período de 2000 a 2004, as transferências do FUNDEF não demonstram efeito sobre o tamanho do ensino fundamental dos municípios, algo refletido no gráfico 1.15 (capítulo 1). Entretanto, a alteração para FUNDEB está negativamente correlacionada com o tamanho do ensino fundamental municipal. Nota-se, novamente, que o coeficiente estimado é pequeno a ponto de se questionar o quanto as transferências realmente afetaram a criação de novas vagas no ensino fundamental.

Os coeficientes estimados para as transferências do FUNDEF e do FUNDEB em todos os modelos anteriormente analisados são influenciados pela própria configuração destes Fundos, que determinou que, no mínimo, 60\% de seus montantes deveriam ser direcionados para o salário dos professores atuantes no ensino fundamental e na educação básica, respectivamente. Assim, apesar de o FUNDEB ter se relacionado positivamente com o aumento de vagas em creches e negativamente com o ensino fundamental, a prévia destinação dos recursos oriundos do FUNDEF e do FUNDEB ao salário dos professores impediu que, com tudo mais constante, diferenças nos valores 
transferidos aos municípios realmente influenciassem na expansão dos diferentes níveis de ensino.

\subsubsection{Partidos Políticos e Criação de Vagas nas Redes Municipais de Ensino}

O partido político do prefeito não tende a apresentar relação com a criação de vagas na rede municipal de ensino. Em momentos pontuais é possível observar uma relação estatisticamente significativa entre ambos, mas ela se desfaz no período seguinte ou é inexistente no período anterior. Os gráficos a seguir exibem o efeito estimado dos partidos observados sobre a criação de vagas na rede municipal de ensino: 
Grafico 5.1: Partidos dos prefeitos e criaçao de vagas em

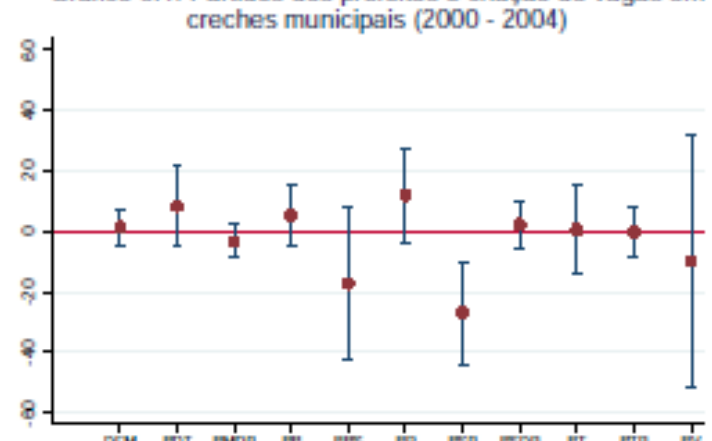

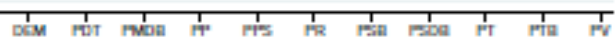

Grafico 5.4: Partidos dos prefeitos e criaçào de vagas em

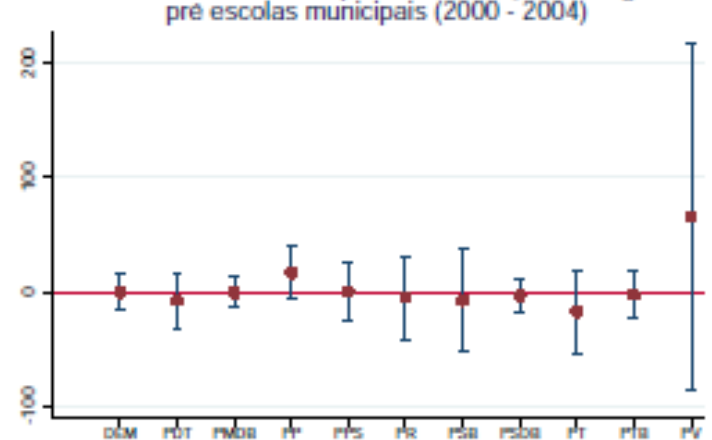

Grafico 5.7: Partidos dos prefeitos e criaçao de vagas no

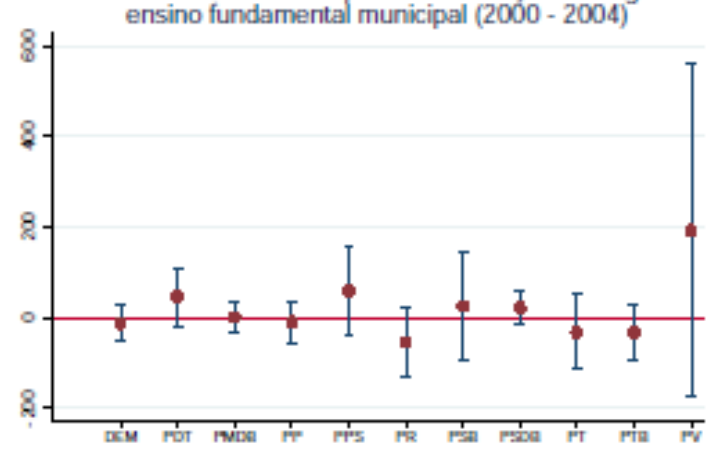

Fonte: Banco de Dados Matrículas e Gastos nos Municípios Brasileiros.

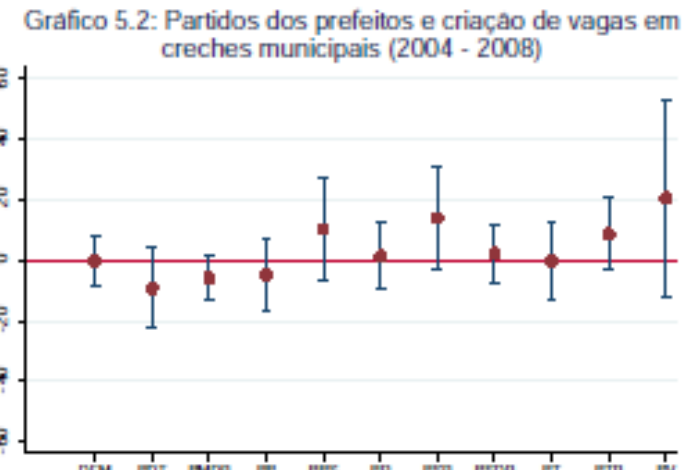

Grafico 5.5: Partidos dos prefeitos e criaçáo de vagas em

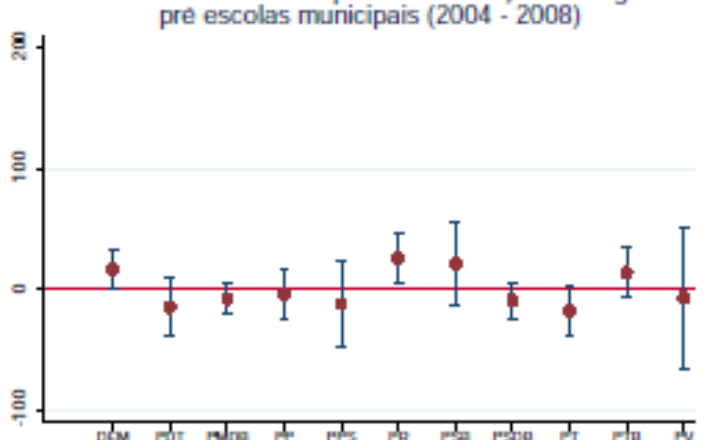

Grafico 5.8: Partidos dos prefeitos e criacáo de vagas no

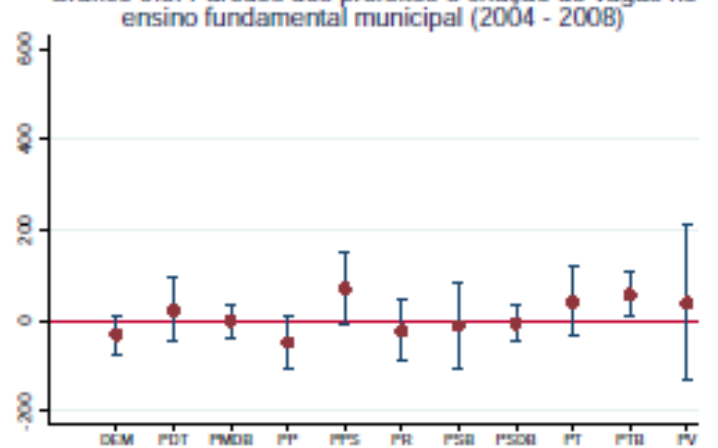

Grafico 5.3: Partidos dos prefeitos e criaçao de vagas em creches municipais (2008 - 2012)

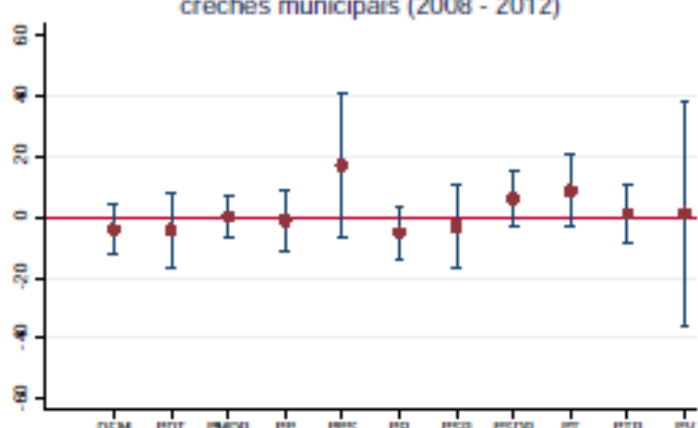

Grafico 5.6: Partidos dos prefeitos e criaçao de vagas em

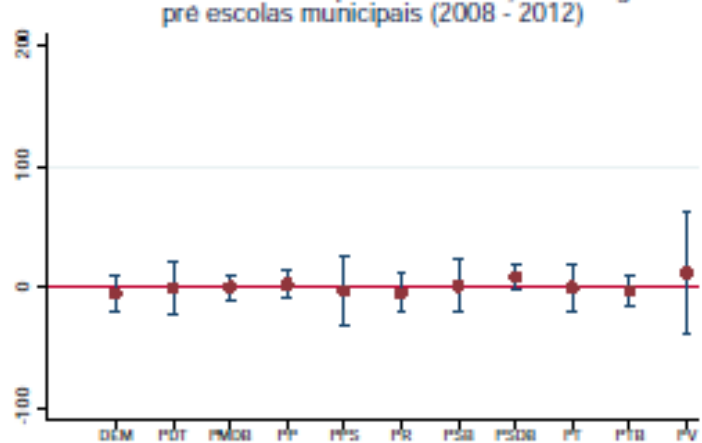

Grafico 5.9: Partidos dos prefeitos e criacáo de vagas no
ensino fundamental municipal (2008 - 2012)

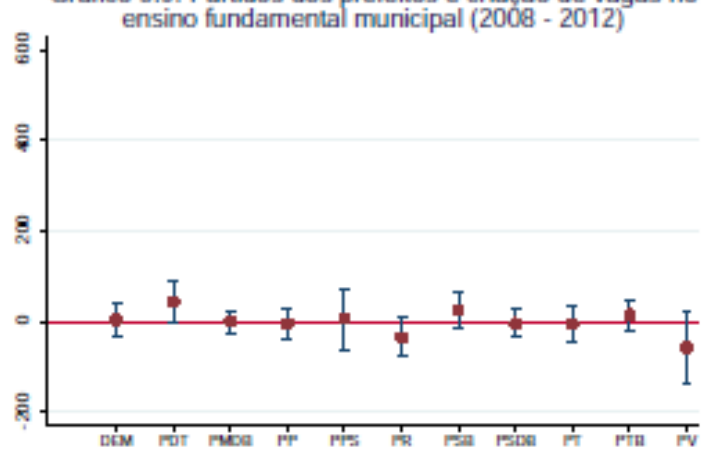


Os modelos utilizados para estimar a criação de vagas nos diferentes níveis de ensino municipal mostraram que o modelo formal desenvolvido anteriormente não se ajusta perfeitamente à política local de educação. Os gráficos acima mostram que nenhum partido parece ter preferências coesas na implementação da política local de educação, para apresentar uma relação estatisticamente significativa que se mantenha ao longo do tempo. Mesmo os partidos que apresentam em algum momento uma relação estatisticamente significativa com a criação de vagas na rede municipal de ensino exibem intervalos de confiança que tendem a se sobrepor ao intervalo de confiança estimado para a maioria dos demais partidos no mesmo período.

Os partidos dos governadores tendem a desempenhar papéis mais bem marcados que os partidos dos prefeitos. Ainda assim, as relações observadas entre estes partidos e a criação de vagas nas redes municipais de ensino não são consistentes ao longo do tempo, o que dificulta a interpretação do significado destas relações. Os gráficos com o efeito estimado dos partidos dos governadores são exibidos a seguir: 

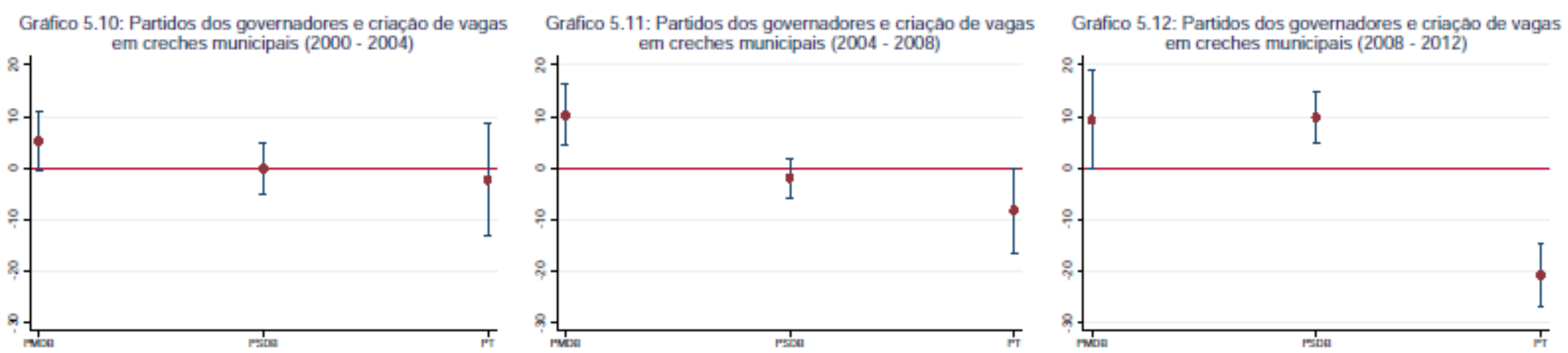

Grafico 5.13: Partidos dos governadores e criaçao de vagas

Grafico 5.14: Partidos dos gowernadores e criaçao de vagas

Grafico 5.15: Partidos dos governadores e criacao de vagas em pre escolas municipais (2000-2004)
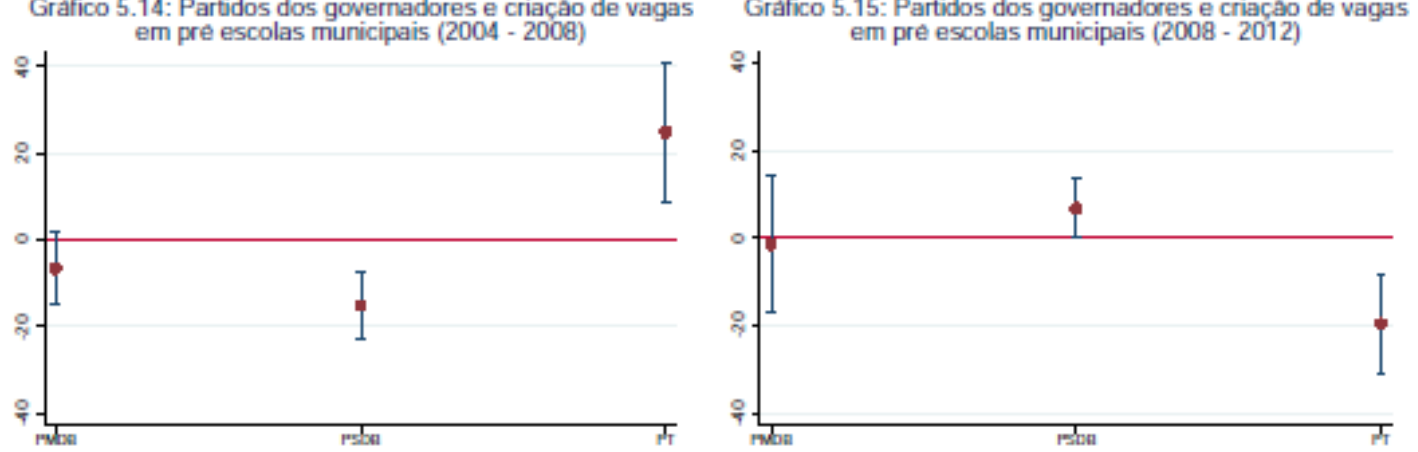

Grafico 5.16: Partidos dos governadores e criaçâo de vagas

Grafico 5.17: Partidos dos governadores e criaçáo de vagas
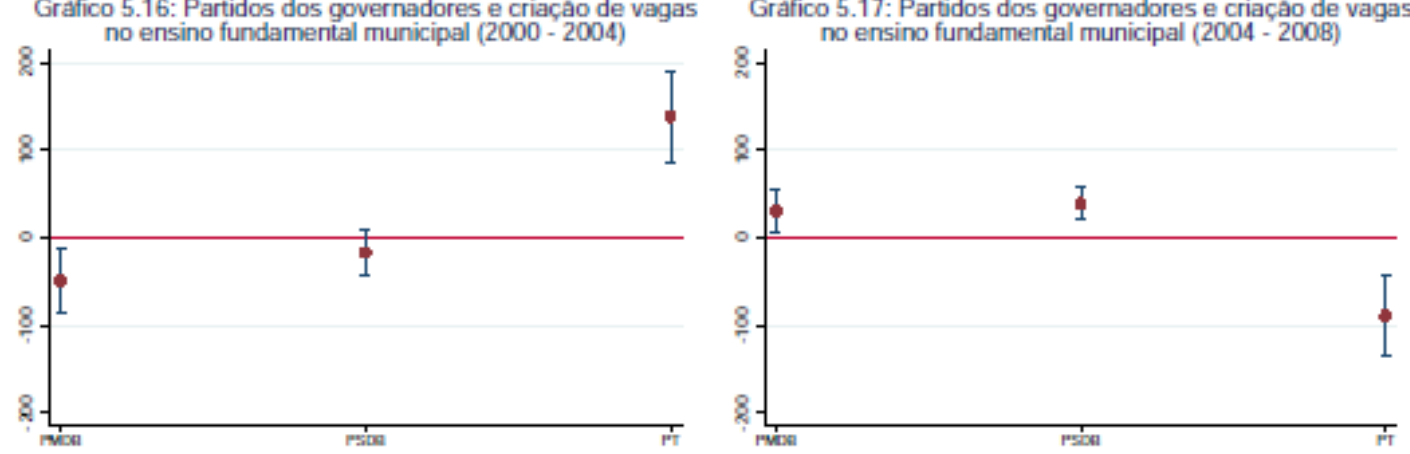

Grafico 5.18: Partidos dos governadores e criaçao de vagas

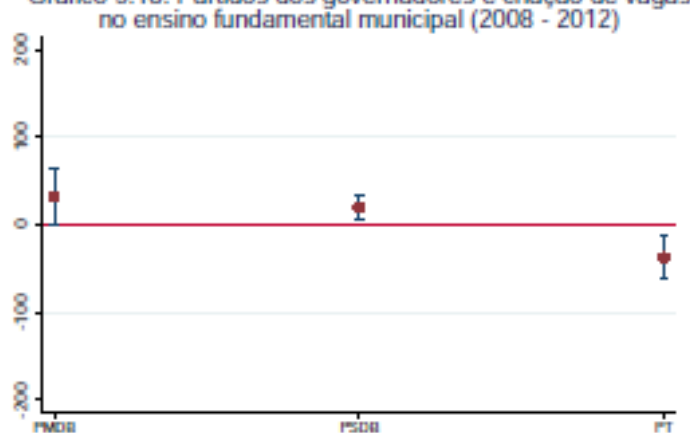

Fonte: Banco de Dados Matrículas e Gastos nos Municípios Brasileiros. 
Nestes gráficos, chamam atenção os seguintes resultados: i) no período de 2009-2012, os governadores do PT estiveram associados à queda no número de vagas nos três níveis das redes municipais de ensino; e ii) em parte das vezes em que os governadores do PT apresentam relação estatisticamente significativa com a criação de vagas nas redes municipais de ensino, esta relação tende a ser o inverso da relação observada para o PMDB e PSDB.

Embora o comportamento observado em i) e ii) não necessariamente reflitam posicionamentos do PT sobre educação na arena federal, estes sugerem que a ação do governo estadual afeta o policy making dos governos locais. O comportamento observador em ii) sugere que há algum fator que não está sendo considerado nos modelos que afeta o comportamento dos governadores. Diferentemente do ocorrido com os partidos dos prefeitos, é possível afirmar que as políticas dos governadores tiveram impacto na criação de vagas pelas redes municipais de ensino. Entretanto, não é possível indicar a lógica que orienta as decisões dos governadores. Apenas é possível afirmar que ela não se orienta necessariamente pela agenda de seu respectivo partido na arena federal.

\subsection{Gastos na Rede Municipal de Ensino}

Achados muito semelhantes foram obtidos com relação à influência dos partidos políticos sobre os gastos em educação e em suas subfunções. Os partidos dos prefeitos não apresentam relação estatisticamente significativa em relação aos gastos. Mesmo quando há relação, os intervalos de confiança dos coeficientes estimados tendem a se sobrepor aos intervalos de confiança dos coeficientes estimados para os demais partidos, de modo que não é possível afirmar que determinado partido influencia os gastos em educação de seus prefeitos e se distingue dos demais.

As tabelas a seguir mostram os modelos estimados para a média da variação no percentual da receita destinada à educação e para a média da variação do percentual dos gastos em educação destinados à educação infantil e ao ensino fundamental. 


\begin{tabular}{|c|c|c|c|c|c|c|c|c|}
\hline & $\begin{array}{l}\text { Modelo } 1 \\
\text { b/se }\end{array}$ & $\begin{array}{c}\text { Modelo } 2 \\
\text { b/se }\end{array}$ & $\begin{array}{l}\text { Modelo } 3 \\
\text { b/se }\end{array}$ & $\begin{array}{c}\text { Modelo } 4 \\
\text { b/se }\end{array}$ & $\begin{array}{l}\text { Modelo } 5 \\
\text { b/se }\end{array}$ & $\begin{array}{c}\text { Modelo } 6 \\
\text { b/se }\end{array}$ & $\begin{array}{c}\text { Modelo } 7 \\
\text { b/se }\end{array}$ & $\begin{array}{c}\text { Modelo } 8 \\
\text { b/se }\end{array}$ \\
\hline \multirow[t]{2}{*}{ L4.Gasto (\%) médio em educação } & $0.10^{* * *}$ & $0.10^{* * *}$ & $0.10^{* * *}$ & $0.10^{* * *}$ & $0.10^{* * *}$ & $0.10^{* * *}$ & $0.09^{* * *}$ & $0.08^{* * *}$ \\
\hline & $(0.01)$ & $(0.01)$ & $(0.01)$ & $(0.01)$ & $(0.01)$ & $(0.01)$ & $(0.01)$ & $(0.01)$ \\
\hline \multirow{2}{*}{$\begin{array}{l}\text { Média das matrículas na rede } \\
\text { municipal }\end{array}$} & $0.00^{* * *}$ & $0.00^{* * *}$ & $0.00^{* * *}$ & $0.00^{* * *}$ & $0.00^{* * *}$ & $0.00^{* * *}$ & $0.00^{* * *}$ & $0.00^{* * *}$ \\
\hline & $(0.00)$ & $(0.00)$ & $(0.00)$ & $(0.00)$ & $(0.00)$ & $(0.00)$ & $(0.00)$ & $(0.00)$ \\
\hline \multirow[t]{2}{*}{ Receita per capita média } & $-0.19^{* * *}$ & $-0.19^{* * *}$ & $-0.19^{* * *}$ & $-0.19^{* * *}$ & $-0.19^{* * *}$ & $-0.20^{* * *}$ & $-0.18^{* * *}$ & $-0.18^{* * *}$ \\
\hline & $(0.02)$ & $(0.02)$ & $(0.02)$ & $(0.02)$ & $(0.01)$ & $(0.02)$ & $(0.02)$ & $(0.01)$ \\
\hline \multirow{2}{*}{$\begin{array}{l}\text { Gasto médio (\%) dos governadores } \\
\text { em educação }\end{array}$} & $0.08^{*}$ & $0.08^{*}$ & $0.08^{*}$ & $0.08^{*}$ & $0.26^{* * *}$ & -0.03 & $0.10^{* *}$ & $0.19^{* * *}$ \\
\hline & $(0.04)$ & $(0.04)$ & $(0.04)$ & $(0.04)$ & $(0.05)$ & $(0.04)$ & $(0.04)$ & $(0.05)$ \\
\hline \multirow[t]{2}{*}{ Continuidade } & 0.29 & & & & 0.35 & 0.26 & 0.06 & 0.12 \\
\hline & $(0.28)$ & & & & $(0.27)$ & $(0.28)$ & $(0.26)$ & $(0.25)$ \\
\hline \multirow{2}{*}{$\begin{array}{l}\text { Distância entre eleito e segundo } \\
\text { mais votado }\end{array}$} & & 0.01 & & & 0.01 & 0.01 & 0.01 & 0.01 \\
\hline & & $(0.01)$ & & & $(0.01)$ & $(0.01)$ & $(0.01)$ & $(0.01)$ \\
\hline \multirow[t]{2}{*}{ Antecedido pelo PSDB } & & & -0.08 & & -0.33 & -0.04 & 0.03 & -0.18 \\
\hline & & & $(0.32)$ & & $(0.32)$ & $(0.32)$ & $(0.31)$ & $(0.31)$ \\
\hline \multirow[t]{2}{*}{ Antecedido pelo PT } & & & & -1.15 & -1.19 & -1.12 & -0.91 & -0.92 \\
\hline & & & & $(0.86)$ & $(0.86)$ & $(0.86)$ & $(0.86)$ & $(0.83)$ \\
\hline \multirow[t]{2}{*}{ Governador do PMDB } & & & & & $-1.53^{* * *}$ & & & $-1.95^{* * *}$ \\
\hline & & & & & $(0.19)$ & & & $(0.22)$ \\
\hline \multirow[t]{2}{*}{ Governador do PSDB } & & & & & & $-0.92^{* * *}$ & & $-1.10^{* * *}$ \\
\hline & & & & & & $(0.17)$ & & $(0.20)$ \\
\hline \multirow[t]{2}{*}{ Governador do PT } & & & & & & & $3.57^{* * *}$ & $2.59^{* * *}$ \\
\hline & & & & & & & $(0.33)$ & $(0.35)$ \\
\hline \multirow[t]{2}{*}{ Constant } & $22.50^{* * *}$ & $22.47^{* * *}$ & $22.57^{* * *}$ & $22.65^{* * *}$ & $20.73^{* * *}$ & $25.31^{* * *}$ & $22.20^{* * *}$ & $23.40^{* * *}$ \\
\hline & $(0.70)$ & $(0.70)$ & $(0.70)$ & $(0.70)$ & $(0.74)$ & $(0.91)$ & $(0.69)$ & $(0.88)$ \\
\hline r2 & 0.429 & 0.430 & 0.429 & 0.430 & 0.451 & 0.443 & 0.476 & 0.503 \\
\hline r2_a & 0.428 & 0.428 & 0.427 & 0.428 & 0.448 & 0.440 & 0.472 & 0.500 \\
\hline Aic & 9059 & 9058 & 9060 & 9059 & 9009 & 9031 & 8941 & 8863 \\
\hline $\mathrm{N}$ & 1501 & 1501 & 1501 & 1501 & 1501 & 1501 & 1501 & 1501 \\
\hline
\end{tabular}

$* \mathrm{p}<0.05, * * \mathrm{p}<0.01, * * * \mathrm{p}<0.001$

Fonte: Banco de Dados Matrículas e Gastos nos Municípios Brasileiros. 
Tabela 5.17: Modelos de Regressão para a Variação dos Gastos na Educação Municipal (2009 - 2012)

\begin{tabular}{|c|c|c|c|c|c|c|c|c|}
\hline & $\begin{array}{c}\text { Modelo } 1 \\
\text { b/se }\end{array}$ & $\begin{array}{c}\text { Modelo } 2 \\
\text { b/se }\end{array}$ & $\begin{array}{c}\text { Modelo } 3 \\
\text { b/se }\end{array}$ & $\begin{array}{c}\text { Modelo } 4 \\
\text { b/se }\end{array}$ & $\begin{array}{c}\text { Modelo } 5 \\
\text { b/se }\end{array}$ & $\begin{array}{c}\text { Modelo } 6 \\
\text { b/se }\end{array}$ & $\begin{array}{c}\text { Modelo } 7 \\
\text { b/se }\end{array}$ & $\begin{array}{c}\text { Modelo } 8 \\
\text { b/se }\end{array}$ \\
\hline \multirow[t]{2}{*}{ L4.Gasto (\%) Médio em educação } & $0.93^{* * *}$ & $0.93^{* * *}$ & $0.93^{* * *}$ & $0.93^{* * *}$ & $0.93^{* * *}$ & $0.92^{* * *}$ & $0.92^{* * *}$ & $0.92^{* * *}$ \\
\hline & $(0.02)$ & $(0.02)$ & $(0.02)$ & $(0.02)$ & $(0.02)$ & $(0.02)$ & $(0.02)$ & $(0.02)$ \\
\hline \multirow{2}{*}{$\begin{array}{l}\text { Média das matrículas na rede } \\
\text { municipal }\end{array}$} & $0.00^{* * *}$ & $0.00^{* * *}$ & $0.00^{* * *}$ & $0.00^{* * *}$ & $0.00^{* * *}$ & $0.00^{* * *}$ & $0.00^{* * *}$ & $0.00^{* * *}$ \\
\hline & $(0.00)$ & $(0.00)$ & $(0.00)$ & $(0.00)$ & $(0.00)$ & $(0.00)$ & $(0.00)$ & $(0.00)$ \\
\hline \multirow[t]{2}{*}{ Receita per capita média } & $-0.09^{* * *}$ & $-0.09^{* * *}$ & $-0.09^{* * *}$ & $-0.09^{* * *}$ & $-0.09^{* * *}$ & $-0.09^{* * *}$ & $-0.09^{* * *}$ & $-0.09^{* * *}$ \\
\hline & $(0.01)$ & $(0.01)$ & $(0.01)$ & $(0.01)$ & $(0.01)$ & $(0.01)$ & $(0.01)$ & $(0.01)$ \\
\hline \multirow{2}{*}{$\begin{array}{l}\text { Gasto médio (\%) dos governadores } \\
\text { em educação }\end{array}$} & $0.05^{*}$ & $0.05^{*}$ & $0.04^{*}$ & $0.05^{*}$ & 0.04 & $0.05^{*}$ & $0.05^{*}$ & $0.04^{*}$ \\
\hline & $(0.02)$ & $(0.02)$ & $(0.02)$ & $(0.02)$ & $(0.02)$ & $(0.02)$ & $(0.02)$ & $(0.02)$ \\
\hline \multirow[t]{2}{*}{ Continuidade } & -0.15 & & & & -0.21 & -0.21 & -0.20 & -0.22 \\
\hline & $(0.18)$ & & & & $(0.18)$ & $(0.18)$ & $(0.18)$ & $(0.18)$ \\
\hline \multirow{2}{*}{$\begin{array}{l}\text { Distância entre eleito e segundo } \\
\text { mais votado }\end{array}$} & & 0.00 & & & 0.00 & 0.00 & 0.00 & 0.01 \\
\hline & & $(0.00)$ & & & $(0.00)$ & $(0.00)$ & $(0.00)$ & $(0.00)$ \\
\hline \multirow[t]{2}{*}{ Antecedido pelo PSDB } & & & 0.37 & & 0.38 & $0.48^{*}$ & $0.45^{*}$ & $0.48^{*}$ \\
\hline & & & $(0.22)$ & & $(0.23)$ & $(0.23)$ & $(0.22)$ & $(0.23)$ \\
\hline \multirow[t]{2}{*}{ Antecedido pelo PT } & & & & 0.35 & 0.49 & 0.50 & 0.47 & 0.55 \\
\hline & & & & $(0.33)$ & $(0.33)$ & $(0.33)$ & $(0.33)$ & $(0.34)$ \\
\hline \multirow[t]{2}{*}{ Governador do PMDB } & & & & & -0.39 & & & -0.52 \\
\hline & & & & & $(0.26)$ & & & $(0.27)$ \\
\hline \multirow[t]{2}{*}{ Governador do PSDB } & & & & & & -0.24 & & $-0.30^{*}$ \\
\hline & & & & & & $(0.14)$ & & $(0.15)$ \\
\hline \multirow[t]{2}{*}{ Governador do PT } & & & & & & & 0.28 & 0.09 \\
\hline & & & & & & & $(0.25)$ & $(0.27)$ \\
\hline \multirow[t]{2}{*}{ Constant } & $4.04^{* * *}$ & $3.93^{* * *}$ & $3.93^{* * *}$ & $3.91^{* * *}$ & $3.92^{* * *}$ & $4.08^{* * *}$ & $3.92^{* * *}$ & $4.22^{* * *}$ \\
\hline & $(0.64)$ & $(0.64)$ & $(0.64)$ & $(0.64)$ & $(0.65)$ & $(0.66)$ & $(0.66)$ & $(0.66)$ \\
\hline r2 & 0.793 & 0.793 & 0.793 & 0.793 & 0.794 & 0.794 & 0.794 & 0.794 \\
\hline r2_a & 0.792 & 0.792 & 0.792 & 0.792 & 0.792 & 0.793 & 0.792 & 0.793 \\
\hline aic & 8033 & 8033 & 8031 & 8033 & 8033 & 8033 & 8034 & 8032 \\
\hline $\mathrm{N}$ & 1501 & 1501 & 1501 & 1501 & 1501 & 1501 & 1501 & 1501 \\
\hline
\end{tabular}

$* \mathrm{p}<0.05, * * \mathrm{p}<0.01, * * * \mathrm{p}<0.001$

Fonte: Banco de Dados Matrículas e Gastos nos Municípios Brasileiros. 
Tabela 5.18: Modelos de Regressão para a Variação dos Gastos em Educação Infantil Municipal (2009 - 2012)

\begin{tabular}{|c|c|c|c|c|c|c|c|c|}
\hline & $\begin{array}{l}\text { Modelo } 1 \\
\text { b/se }\end{array}$ & $\begin{array}{c}\text { Modelo } 2 \\
\text { b/se }\end{array}$ & $\begin{array}{c}\text { Modelo } 3 \\
\text { b/se }\end{array}$ & $\begin{array}{c}\text { Modelo } 4 \\
\text { b/se }\end{array}$ & $\begin{array}{c}\text { Modelo } 5 \\
\text { b/se }\end{array}$ & $\begin{array}{c}\text { Modelo } 6 \\
\text { b/se }\end{array}$ & $\begin{array}{c}\text { Modelo } 7 \\
\text { b/se }\end{array}$ & $\begin{array}{c}\text { Modelo } 8 \\
\text { b/se }\end{array}$ \\
\hline \multirow{2}{*}{$\begin{array}{l}\text { L4.Gasto (\%) médio em educação } \\
\text { infantil }\end{array}$} & $0.87^{* * *}$ & $0.87^{* * *}$ & $0.87^{* * *}$ & $0.87^{* * *}$ & $0.87^{* * *}$ & $0.87^{* * *}$ & $0.86^{* * *}$ & $0.87^{* * *}$ \\
\hline & $(0.02)$ & $(0.02)$ & $(0.02)$ & $(0.02)$ & $(0.02)$ & $(0.02)$ & $(0.02)$ & $(0.02)$ \\
\hline \multirow[t]{2}{*}{ Pop. idade ideal (\%) } & $-0.59^{* * *}$ & $-0.60^{* * *}$ & $-0.59^{* * *}$ & $-0.60^{* * *}$ & $-0.60^{* * *}$ & $-0.59^{* * *}$ & $-0.60^{* * *}$ & $-0.61^{* * *}$ \\
\hline & $(0.08)$ & $(0.08)$ & $(0.08)$ & $(0.08)$ & $(0.08)$ & $(0.08)$ & $(0.08)$ & $(0.09)$ \\
\hline \multirow{2}{*}{$\begin{array}{l}\text { Média de matrículas na educação } \\
\text { infantil municipal }\end{array}$} & 0.00 & 0.00 & 0.00 & 0.00 & 0.00 & 0.00 & $0.00^{*}$ & 0.00 \\
\hline & $(0.00)$ & $(0.00)$ & $(0.00)$ & $(0.00)$ & $(0.00)$ & $(0.00)$ & $(0.00)$ & $(0.00)$ \\
\hline \multirow{2}{*}{$\begin{array}{l}\text { Média de matrículas na educação } \\
\text { infantil estadual }\end{array}$} & 0.01 & 0.01 & 0.01 & 0.01 & 0.01 & 0.01 & 0.01 & 0.01 \\
\hline & $(0.01)$ & $(0.01)$ & $(0.01)$ & $(0.01)$ & $(0.01)$ & $(0.01)$ & $(0.01)$ & $(0.01)$ \\
\hline \multirow[t]{2}{*}{ Receita per capita média } & 0.02 & 0.02 & 0.02 & 0.02 & 0.02 & 0.02 & 0.02 & 0.02 \\
\hline & $(0.02)$ & $(0.02)$ & $(0.02)$ & $(0.02)$ & $(0.02)$ & $(0.02)$ & $(0.02)$ & $(0.02)$ \\
\hline \multirow{2}{*}{$\begin{array}{l}\text { Gasto médio (\%) dos governadores } \\
\text { em educação }\end{array}$} & -0.06 & $-0.06^{*}$ & -0.06 & -0.06 & -0.06 & -0.06 & $-0.07^{*}$ & $-0.06^{*}$ \\
\hline & $(0.03)$ & $(0.03)$ & $(0.03)$ & $(0.03)$ & $(0.03)$ & $(0.03)$ & $(0.03)$ & $(0.03)$ \\
\hline \multirow[t]{2}{*}{ Continuidade } & $0.66^{*}$ & & & & $0.55^{*}$ & $0.54^{*}$ & $0.53^{*}$ & $0.52^{*}$ \\
\hline & $(0.26)$ & & & & $(0.26)$ & $(0.26)$ & $(0.26)$ & $(0.26)$ \\
\hline \multirow{2}{*}{$\begin{array}{l}\text { Distância entre eleito e segundo } \\
\text { mais votado }\end{array}$} & & $0.01^{*}$ & & & 0.01 & 0.01 & 0.01 & 0.01 \\
\hline & & $(0.01)$ & & & $(0.01)$ & $(0.01)$ & $(0.01)$ & $(0.01)$ \\
\hline \multirow[t]{2}{*}{ Antecedido pelo PSDB } & & & $-0.81^{*}$ & & $-0.72^{*}$ & -0.69 & $-0.85^{*}$ & $-0.75^{*}$ \\
\hline & & & $(0.36)$ & & $(0.36)$ & $(0.36)$ & $(0.36)$ & $(0.36)$ \\
\hline \multirow[t]{2}{*}{ Antecedido pelo PT } & & & & $1.02^{*}$ & 0.77 & 0.83 & 0.80 & 0.81 \\
\hline & & & & $(0.52)$ & $(0.52)$ & $(0.52)$ & $(0.52)$ & $(0.52)$ \\
\hline \multirow[t]{2}{*}{ Governador do PMDB } & & & & & 0.38 & & & 0.11 \\
\hline & & & & & $(0.35)$ & & & $(0.37)$ \\
\hline \multirow[t]{2}{*}{ Governador do PSDB } & & & & & & -0.16 & & -0.31 \\
\hline & & & & & & $(0.22)$ & & $(0.24)$ \\
\hline \multirow[t]{2}{*}{ Governador do PT } & & & & & & & $-0.55^{*}$ & $-0.66^{*}$ \\
\hline & & & & & & & $(0.25)$ & $(0.26)$ \\
\hline \multirow[t]{2}{*}{ Constant } & $8.70^{* * *}$ & $8.85^{* * *}$ & $9.11^{* * *}$ & $8.95^{* * *}$ & $8.66^{* * *}$ & $8.64^{* * *}$ & $9.06^{* * *}$ & $9.22^{* * *}$ \\
\hline & $(1.07)$ & $(1.06)$ & $(1.07)$ & $(1.07)$ & $(1.06)$ & $(1.06)$ & (1.09) & $(1.09)$ \\
\hline r2 & 0.625 & 0.624 & 0.624 & 0.624 & 0.626 & 0.626 & 0.627 & 0.627 \\
\hline r2_a & 0.624 & 0.623 & 0.623 & 0.623 & 0.625 & 0.625 & 0.625 & 0.625 \\
\hline Aic & 18488 & 18489 & 18489 & 18491 & 18484 & 18484 & 18480 & 18481 \\
\hline N & 2785 & 2785 & 2785 & 2785 & 2785 & 2785 & 2785 & 2785 \\
\hline
\end{tabular}

${ }^{*} \mathrm{p}<0.05,{ }^{* *} \mathrm{p}<0.01,{ }^{* * *} \mathrm{p}<0.001$

Fonte: Banco de Dados Matrículas e Gastos nos Municípios Brasileiros. 


\begin{tabular}{|c|c|c|c|c|c|c|c|c|}
\hline & $\begin{array}{l}\text { Modelo } 1 \\
\text { b/se }\end{array}$ & $\begin{array}{c}\text { Modelo } 2 \\
\text { b/se }\end{array}$ & $\begin{array}{c}\text { Modelo } 3 \\
\text { b/se }\end{array}$ & $\begin{array}{c}\text { Modelo } 4 \\
\text { b/se }\end{array}$ & $\begin{array}{l}\text { Modelo } 5 \\
\text { b/se }\end{array}$ & $\begin{array}{c}\text { Modelo } 6 \\
\text { b/se }\end{array}$ & $\begin{array}{c}\text { Modelo } 7 \\
\text { b/se }\end{array}$ & $\begin{array}{c}\text { Modelo } 8 \\
\text { b/se }\end{array}$ \\
\hline $\begin{array}{l}\text { L4.Gasto }(\%) \text { médio em ensino } \\
\text { fundamental }\end{array}$ & $\begin{array}{l}0.54^{* * *} \\
(0.03)\end{array}$ & $\begin{array}{l}0.54^{* * *} \\
(0.03)\end{array}$ & $\begin{array}{l}0.54^{* * *} \\
(0.03)\end{array}$ & $\begin{array}{l}0.54^{* * *} \\
(0.03)\end{array}$ & $\begin{array}{l}0.54^{* * *} \\
(0.03)\end{array}$ & $\begin{array}{l}0.53^{* * *} \\
(0.03)\end{array}$ & $\begin{array}{l}0.54^{* * *} \\
(0.03)\end{array}$ & $\begin{array}{l}0.53^{* * *} \\
(0.03)\end{array}$ \\
\hline Pop. idade ideal (\%) & $\begin{array}{l}0.68^{* * *} \\
(0.12)\end{array}$ & $\begin{array}{l}0.69^{* * *} \\
(0.12)\end{array}$ & $\begin{array}{l}0.68^{* * *} \\
(0.12)\end{array}$ & $\begin{array}{l}0.69^{* * *} \\
(0.12)\end{array}$ & $\begin{array}{l}0.68^{* * *} \\
(0.12)\end{array}$ & $\begin{array}{l}0.64^{* * *} \\
(0.12)\end{array}$ & $\begin{array}{l}0.69^{* * *} \\
(0.12)\end{array}$ & $\begin{array}{l}0.66^{* * *} \\
(0.12)\end{array}$ \\
\hline $\begin{array}{l}\text { Média de matrículas no ensino } \\
\text { fundamental municipal }\end{array}$ & $\begin{array}{c}0.00 \\
(0.00)\end{array}$ & $\begin{array}{c}0.00 \\
(0.00)\end{array}$ & $\begin{array}{c}0.00 \\
(0.00)\end{array}$ & $\begin{array}{c}0.00 \\
(0.00)\end{array}$ & $\begin{array}{c}0.00 \\
(0.00)\end{array}$ & $\begin{array}{l}-0.00 \\
(0.00)\end{array}$ & $\begin{array}{l}-0.00 \\
(0.00)\end{array}$ & $\begin{array}{l}-0.00 \\
(0.00)\end{array}$ \\
\hline $\begin{array}{l}\text { Média de matrículas no ensino } \\
\text { fundamental estadual }\end{array}$ & $\begin{array}{l}-0.00^{* * *} \\
(0.00)\end{array}$ & $\begin{array}{l}-0.00^{* * *} \\
(0.00)\end{array}$ & $\begin{array}{l}-0.00^{* * *} \\
(0.00)\end{array}$ & $\begin{array}{l}-0.00^{* * *} \\
(0.00)\end{array}$ & $\begin{array}{l}-0.00^{* * *} \\
(0.00)\end{array}$ & $\begin{array}{l}-0.00^{* * *} \\
(0.00)\end{array}$ & $\begin{array}{l}-0.00^{* * *} \\
(0.00)\end{array}$ & $\begin{array}{l}-0.00^{* * *} \\
(0.00)\end{array}$ \\
\hline Receita per capita média & $\begin{array}{l}-0.13^{* * *} \\
(0.03)\end{array}$ & $\begin{array}{l}-0.13^{* * *} \\
(0.03)\end{array}$ & $\begin{array}{l}-0.13^{* * *} \\
(0.03)\end{array}$ & $\begin{array}{l}-0.13^{* * *} \\
(0.03)\end{array}$ & $\begin{array}{l}-0.13^{* * *} \\
(0.03)\end{array}$ & $\begin{array}{l}-0.12^{* * *} \\
(0.03)\end{array}$ & $\begin{array}{l}-0.12^{* * *} \\
(0.03)\end{array}$ & $\begin{array}{l}-0.11^{* * *} \\
(0.03)\end{array}$ \\
\hline $\begin{array}{l}\text { Gasto médio (\%) dos } \\
\text { governadores em ensino } \\
\text { fundamental }\end{array}$ & $\begin{array}{l}0.01 \\
(0.01)\end{array}$ & $\begin{array}{l}0.01 \\
(0.01)\end{array}$ & $\begin{array}{l}0.01 \\
(0.01)\end{array}$ & $\begin{array}{c}0.01 \\
(0.01)\end{array}$ & $\begin{array}{l}0.01 \\
(0.02)\end{array}$ & $\begin{array}{l}0.01 \\
(0.01)\end{array}$ & $\begin{array}{l}0.02 \\
(0.02)\end{array}$ & $\begin{array}{l}0.02 \\
(0.02)\end{array}$ \\
\hline Continuidade & $\begin{array}{l}-0.31 \\
(0.51)\end{array}$ & & & & $\begin{array}{l}-0.28 \\
(0.53)\end{array}$ & $\begin{array}{l}-0.31 \\
(0.53)\end{array}$ & $\begin{array}{l}-0.20 \\
(0.53)\end{array}$ & $\begin{array}{l}-0.27 \\
(0.53)\end{array}$ \\
\hline $\begin{array}{l}\text { Distância entre eleito e } \\
\text { segundo mais votado }\end{array}$ & & $\begin{array}{l}-0.00 \\
(0.01)\end{array}$ & & & $\begin{array}{l}-0.00 \\
(0.01)\end{array}$ & $\begin{array}{c}0.00 \\
(0.01)\end{array}$ & $\begin{array}{c}0.00 \\
(0.01)\end{array}$ & $\begin{array}{c}0.00 \\
(0.01)\end{array}$ \\
\hline Antecedido pelo PSDB & & & $\begin{array}{l}-0.84 \\
(0.67)\end{array}$ & & $\begin{array}{l}-0.88 \\
(0.67)\end{array}$ & $\begin{array}{l}-0.49 \\
(0.68)\end{array}$ & $\begin{array}{l}-0.57 \\
(0.67)\end{array}$ & $\begin{array}{l}-0.37 \\
(0.68)\end{array}$ \\
\hline Antecedido pelo PT & & & & $\begin{array}{l}-0.33 \\
(0.82)\end{array}$ & $\begin{array}{l}-0.39 \\
(0.84)\end{array}$ & $\begin{array}{l}-0.23 \\
(0.85)\end{array}$ & $\begin{array}{l}-0.52 \\
(0.85)\end{array}$ & $\begin{array}{l}-0.32 \\
(0.85)\end{array}$ \\
\hline Governador do PMDB & & & & & $\begin{array}{l}-0.23 \\
(0.76)\end{array}$ & & & $\begin{array}{l}-0.57 \\
(0.79)\end{array}$ \\
\hline Governador do PSDB & & & & & & $\begin{array}{l}-1.27^{* * *} \\
(0.36)\end{array}$ & & $\begin{array}{l}-1.11^{* *} \\
(0.40)\end{array}$ \\
\hline Governador do PT & & & & & & & $\begin{array}{l}1.40^{*} \\
(0.58)\end{array}$ & $\begin{array}{c}0.96 \\
(0.62)\end{array}$ \\
\hline Constant & $\begin{array}{c}27.21^{* * *} \\
(2.70)\end{array}$ & $\begin{array}{c}27.07^{* * *} \\
(2.67)\end{array}$ & $\begin{array}{c}27.36^{* * *} \\
(2.69)\end{array}$ & $\begin{array}{c}27.08^{* * *} \\
(2.68)\end{array}$ & $\begin{array}{c}27.41^{* * *} \\
(2.73)\end{array}$ & $\begin{array}{c}29.28^{* * *} \\
(2.83)\end{array}$ & $\begin{array}{c}26.51^{* * *} \\
(2.71)\end{array}$ & $\begin{array}{c}28.08^{* * *} \\
(2.86)\end{array}$ \\
\hline r2 & 0.328 & 0.328 & 0.328 & 0.328 & 0.328 & 0.331 & 0.331 & 0.333 \\
\hline r2_a & 0.326 & 0.325 & 0.326 & 0.326 & 0.325 & 0.328 & 0.328 & 0.329 \\
\hline aic & 17969 & 17969 & 17968 & 17969 & 17975 & 17965 & 17966 & 17964 \\
\hline $\mathrm{N}$ & 2297 & 2297 & 2297 & 2297 & 2297 & 2297 & 2297 & 2297 \\
\hline
\end{tabular}

Os resultados mais interessantes, em relação ao inicialmente esperado, são observados nos modelos referentes aos gastos em educação infantil. Nestes modelos é possível observar que os prefeitos antecedidos pelo PSDB tendem a direcionar para a educação infantil $0,81 \%$ a menos que os antecedidos por prefeitos dos demais partidos e que os prefeitos antecedidos pelos prefeitos do PT tendem a direcionar para educação infantil 
$1,02 \%$ a mais que os antecedidos pelos demais prefeitos. A inexistência de relação entre estes partidos e o gasto em educação infantil (gráfico 5.21) ao mesmo tempo em que o efeito negativo da gestão prévia desses mesmos partidos sobre os gastos é estatisticamente significativo lembra novamente Rose (1990), que afirma que muitas vezes os governos influenciam as políticas anos após terem deixado o gabinete. Entretanto, a inconstância destas variáveis nos modelos referentes à criação de vagas impede que possa ser afirmado que esta relação estatisticamente significativa se mantém ao longo do tempo.

Os gráficos a seguir mostram o efeito estimado do partido político dos prefeitos sobre os gastos em educação e suas subfunções:
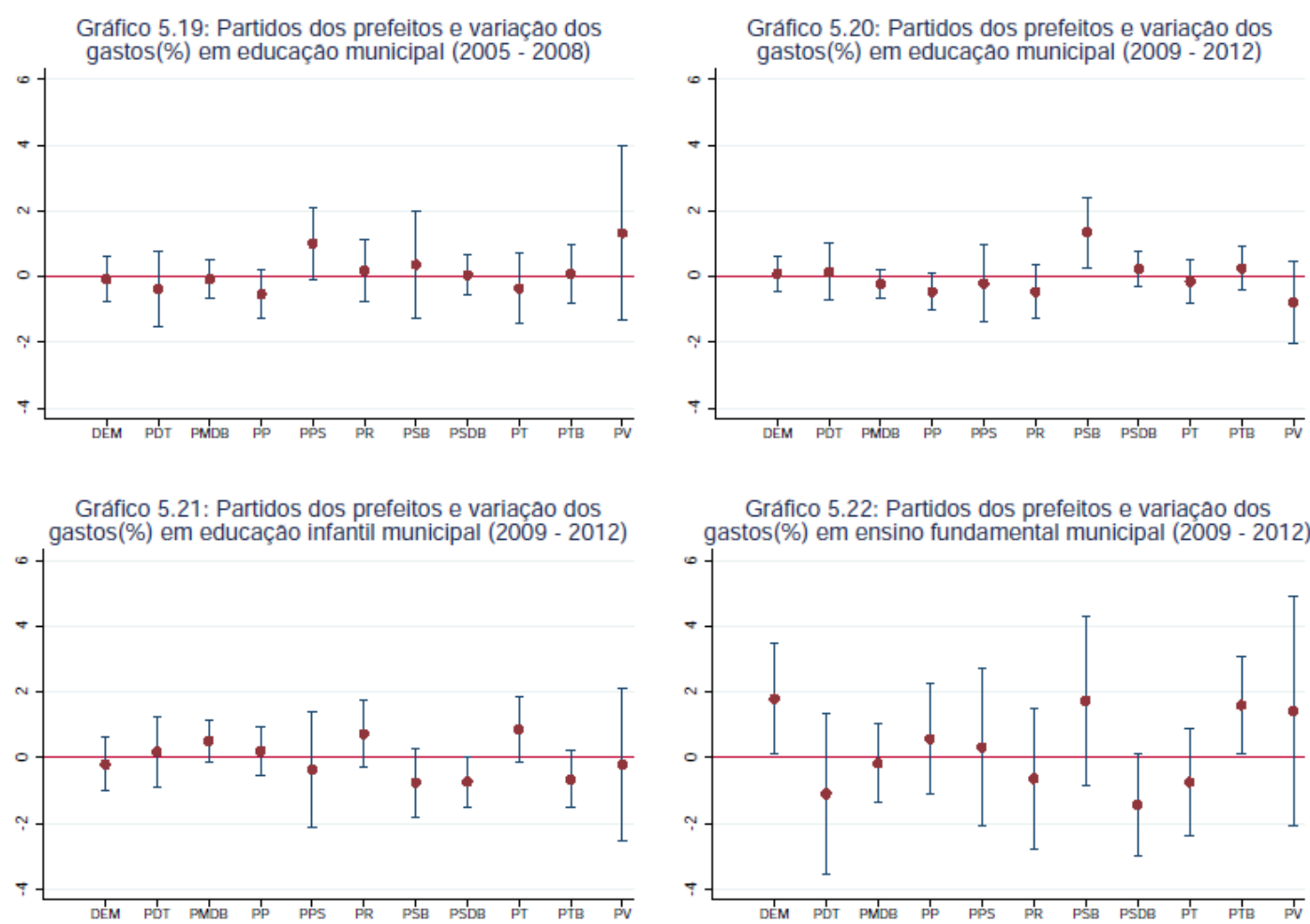

Fonte: Banco de Dados Matrículas e Gastos nos Municípios Brasileiros.

Apenas três partidos apresentam relação estatisticamente significativa com a variação nos gastos (DEM, PSB e PTB) e nenhum deles apresenta algo que possa ser identificado como um padrão ou como diferente do apresentado pelos demais partidos. 
A relação dos governadores com a variação ocorrida nos gastos em educação traz semelhanças com o observado na criação de vagas nas redes municipais de ensino. Os gráficos com os efeitos estimados dos partidos dos governadores são exibidos a seguir:
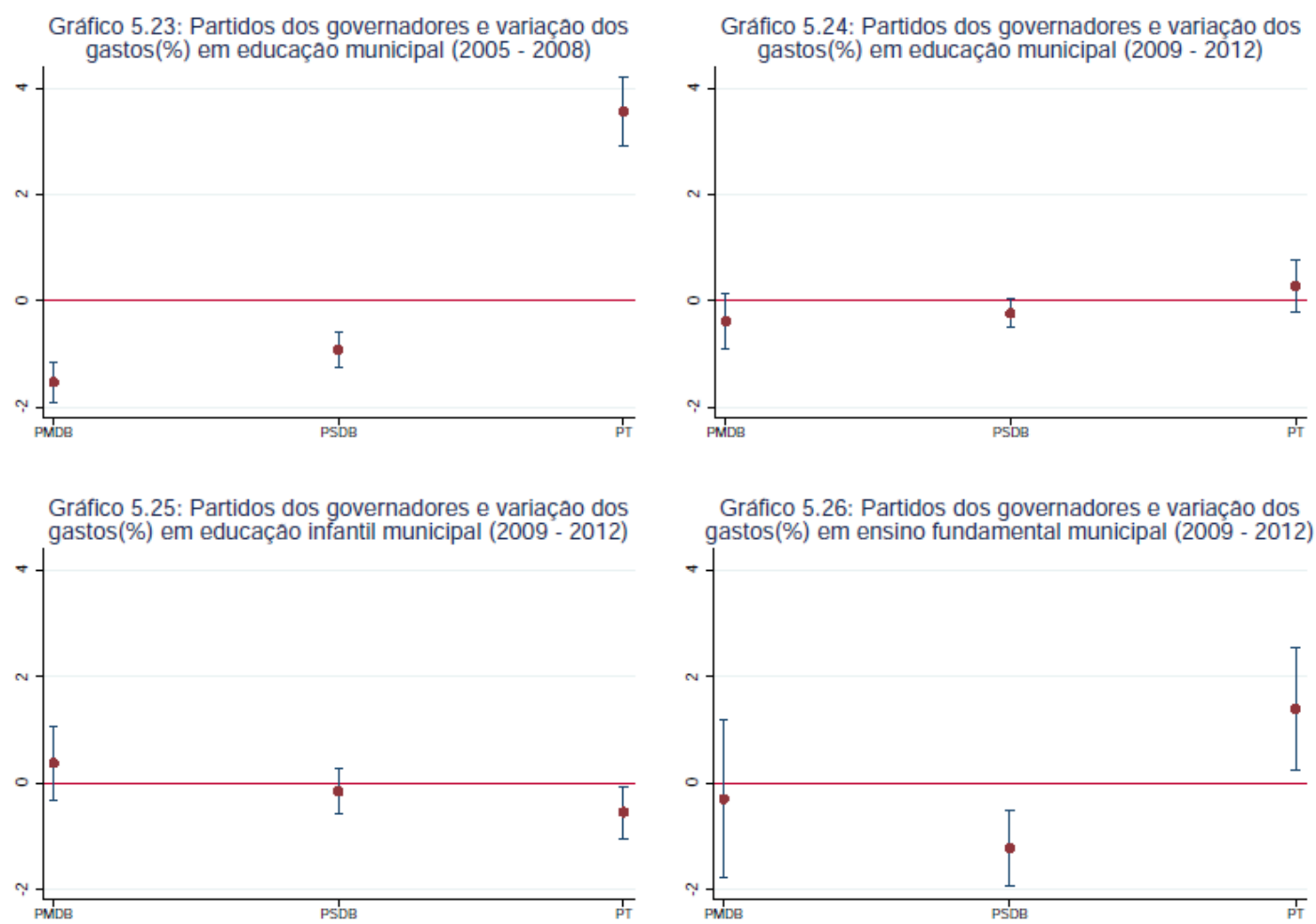

Fonte: Banco de Dados Matrículas e Gastos nos Municípios Brasileiros.

Os governadores do PT e do PSDB tenderam a se destacar em direções opostas nos gastos em educação no período de 2005 a 2008 e nos gastos em ensino fundamental no período de 2009 a 2012. Algo importante nos gráficos e nos modelos de regressão é que no período de 2005 a 2008 o percentual direcionado à educação na gestão anterior tinha pequena influência sobre os gastos na gestão atual. Por exemplo, a maioria dos modelos da tabela 5.10 mostra que em média o percentual da receita municipal direcionada à educação na gestão de 2001-2004 tendia a influenciar em 10\% os valores observados na gestão de 2005-2008. Entretanto, o percentual direcionado à educação na gestão de 2005-2008 passou a influenciar em 93\% dos valores observados na gestão de 2009-2012 (tabela 5.11). Isto mostra que no período de 2009-2012, os orçamentos ficaram bem mais engessados do que eles eram anteriormente. Consequentemente, apesar de os partidos dos governadores ainda apontarem na mesma direção que apontavam no 
período anterior, todos eles deixam de ter relação estatisticamente significativa com a variação da receita destinada à educação.

\subsection{Resultados dos Testes de Hipóteses}

É possível afirmar que o pertencimento partidário dos prefeitos tende a não influenciar a criação de vagas no ensino municipal nem a variação dos gastos em educação e em suas subfunções. A seguir discorre-se sobre os resultados das hipóteses apresentadas no capítulo anterior:

1) As transferências do FUNDEF e o FUNDEB tiveram efeitos distintos sobre as matrículas e sobre a forma como os prefeitos distribuíram seus gastos em educação.

Esta hipótese se confirma para o ensino fundamental. Nos dois últimos períodos observados, as transferências do Fundo estiveram negativamente correlacionadas com o aumento do ensino fundamental municipal, enquanto que no primeiro período o FUNDEF não apresentou correlação estatisticamente significativa. Os resultados observados também permitem um melhor entendimento da relação entre as transferências dos Fundos e a expansão das matrículas nos municípios.

O FUNDEF teve um papel importante na forma como influenciou a política local de educação. Exemplo disto está em Menezes-Filho e Pazello (2004) que mostram que, devido às regras de transferência do Fundo, mesmo os municípios que perderam receita tenderam a elevar o salário de seus professores de ensino fundamental.

Os resultados encontrados para as transferências do FUNDEB são contrários aos esperados, no sentido em que mais transferências não se relacionaram com a expansão das creches e pré escolas municipais. Um fator importante que pode explicar isto é que o FUNDEF agiu em um ambiente onde não haviam constrangimentos próximos daqueles que ele viria estabelecer. Ao vincular $60 \%$ dos repasses do Fundo ao salário dos professores de ensino fundamental, o Fundo criou um novo constrangimento nos gastos em educação que limitou os efeitos de seu sucessor, o FUNDEB. 
O capítulo 1 mostrou que a partir da implementação do FUNDEB houve crescimento no ritmo de expansão das creches municipais. O que foi mostrado no capítulo 5 é que, com tudo mais constante, o aumento das matrículas em creches municipais não está vinculado às transferências do FUNDEB recebidas pelos municípios. Um dos motivos para que isto ocorra é o fato de que o impacto do FUNDEB em comparação com o cenário que o antecedeu é menor que aquele do FUNDEF quando comparado com o período anterior à sua implementação. Quando o FUNDEF foi implementado expandir o ensino fundamental da rede municipal significava mais receita para o município, ao mesmo tempo que significava a obrigação de direcionar $60 \%$ desta receita para o salário dos atuantes neste nível de ensino. Quando o FUNDEB foi implementado expandir a educação básica significava mais receita para o município, mas os compromissos assumidos com os salários dos professores do ensino fundamental durante o período de vigência do fundo anterior criaram constrangimentos para que as transferências do Fundo tivessem maior impacto na expansão dos demais níveis de ensino da educação básica.

As transferências do Fundo serem recebidas apenas no ano seguinte à realização das matrículas poderia ser visto como outro fator que contribui para que as transferências tenham pouca relação com a expansão das redes de ensino. Neste caso, haveria um problema de causalidade reversa, onde as transferências são consequência das matrículas e não o contrário. Ainda assim, se o prefeito expande sua rede de ensino em um ano para receber mais transferências, é esperado que ele faça o mesmo no ano seguinte, logo esta característica das transferências não impediria que se observasse uma relação entre transferências e expansão de vagas.

2) Os prefeitos do PSDB se destacam na criação de vagas no ensino fundamental municipal.

Esta hipótese não se confirma. Em nenhum momento os prefeitos do PSDB apresentam relação estatisticamente significativa com a criação de vagas no ensino fundamental. Mesmo quando é observado se a gestão anterior foi do PSDB não é possível afirmar que há uma relação entre o partido e a criação de vagas no ensino fundamental municipal. 
3) Os prefeitos do PT tendem a ser mais responsivos na política educacional às demandas locais que os prefeitos dos demais partidos.

Esta hipótese também não se confirma. Para o teste desta hipótese foram realizadas interações entre a demanda por vagas nos diferentes níveis de ensino e os partidos dos prefeitos. Estes gráficos são apresentados nos apêndices $C$ e $D$, neles observa-se que, apesar de a demanda estar associada ao aumento de vagas nos diferentes níveis de ensino, o aumento da demanda não tende a gerar maior criação de vagas pelos prefeitos quando observamos seus comportamentos de acordo com o partido ao qual eles pertencem.

4) A variação na distribuição dos gastos dos prefeitos em educação, educação infantil e ensino fundamental refletem posicionamentos de seus respectivos partidos políticos adotados na arena federal.

Apenas no que diz respeito à variação do gasto em educação infantil é possível ver algo próximo de um efeito partidário quando se observa a relação entre uma gestão prévia do PSDB quando ela é comparada com uma gestão prévia do PT. A primeira sugere que os prefeitos antecedidos por prefeitos do PSDB tendem a gastar menos em educação infantil, a segunda sugere que prefeitos antecedidos por prefeitos do PT tendem a gastar mais. Ainda assim, este é o mais próximo que se chega da aprovação desta hipótese com os principais partidos observados neste trabalho. Como nas análises apresentadas em diferentes períodos muitas variáveis de interesse tenderam a apresentar sinais trocados, ou a perder significância estatística, a hipótese 4 é rejeitada. Os demais modelos mostraram que não é possível esperar regularidade na relação entre as variáveis de interesse.

5) Os governadores influenciam a criação de vagas na rede municipal de ensino $e$ os gastos em educação dos prefeitos de acordo com o posicionamento de seus respectivos partidos na arena federal.

Esta hipótese foi refutada, mas a observação do papel dos partidos dos governadores é uma das principais contribuições deste trabalho. Os governadores exercem papel central na decisão que os prefeitos tomam sobre a política de educação de seus municípios (ARRETCHE, 2000; GOMES, 2009). Observa-se que os governadores 
implementam diferentes políticas e que esta implementação é influenciada por seus respectivos partidos políticos. Entretanto, a influência do partido do governador não é exercida de forma constante nem em direção certa ao longo do tempo. Exemplo disto pode ser observado no comportamento dos governadores pertencentes ao PMDB e ao PT sobre a criação de vagas no ensino fundamental da rede municipal no período de 2004-2008. Neste período os governadores destes partidos passaram a apresentar relação oposta à que eles tinham com a expansão das redes municipais de ensino no período anterior (gráficos 5.16 e 5.17). Tecnicamente, isto pode ser interpretado como um viés de variável omitida nos modelos de regressão. Substantivamente, isto significa que há outros fatores além dos apresentados influenciando as preferências e o uso estratégico que os governadores fazem de suas políticas. Ou seja, a relação entre partidos políticos e políticas públicas sofre alterações ao longo do tempo influenciadas por fatores contextuais não observados.

6) A demanda por vagas é central na expansão da rede municipal de educação.

Em todos os modelos esta variável se mantém com sinal positivo e estatisticamente significativo. Como os gráficos nos apêndices C e D permitem observar, os partidos políticos não necessariamente se distinguem em relação à maneira como interagem com a demanda por mais vagas nas escolas e creches. Por isto, afirma-se que a demanda é importante para entender a criação de vagas em creches, independentemente do partido do prefeito que esteja governando.

Os resultados observados indicam que a principal preocupação dos prefeitos é atender a demanda de seus municípios. A existência de demanda resultou na expansão das redes municipais de ensino, indicando que maior número de crianças fora da escola tende a gerar maior esforço dos prefeitos para levar estas crianças para as salas de aula.

\subsection{Conclusões}

Neste capítulo foram apresentados os principais resultados deste trabalho. Concluiu-se que os partidos dos prefeitos não influenciam na política de educação dos municípios. Em parte, isto se deve ao comportamento dos prefeitos de atender a demanda por vagas. Em todos os níveis de ensino, a existência de demanda implicou a expansão da 
rede municipal de ensino, independentemente do partido do prefeito. Quando a tendência é de que os prefeitos reajam positivamente à demanda, é difícil que os partidos se destaquem dos demais. Seriam necessárias preferências intensas e forte coordenação para que isto ocorresse.

Também foi visto que o crescimento da rede estadual ou da rede particular de ensino pode afetar negativamente a expansão da rede municipal. Estes resultados mostraram a importância de que nas análises sobre a relação entre partidos políticos e políticas públicas observe-se como a concorrência com outras redes de serviços afeta a provisão desta política pelo nível de governo analisado.

Uma diferença importante que deve ser destacada na análise sobre o FUNDEF e FUNDEB no capítulo 1 em relação à apresentada no capítulo 5 é que no primeiro capítulo foi observada a relação dos Fundos com o crescimento das matrículas e com a variação dos gastos nos diferentes níveis de ensino mediante o uso de estatísticas descritivas. Desta forma, observou-se como se deu o comportamento dos gastos e matrículas a partir da implementação do FUNDEB sem que houvesse controle sobre como outros fatores também poderiam afetar ambos. No capítulo 5, foi observada a relação que as transferências dos Fundos apresentaram com a expansão da rede municipal de ensino quando os demais fatores que podem influenciar esta expansão são mantidos constantes. É importante destacar que estas análises são complementares. Ambas são auxiliares no processe de inferência sobre o papel que o FUNDEF e o FUNDEB tiveram sobre a expansão da rede municipal de ensino. Enquanto a análise apresentada no capítulo 5 deve ser interpretada de acordo com os critérios dos modelos de regressão utilizados, a análise dos Fundos no capítulo 1 reflete como os Fundos interagiram com a rede municipal de ensino quando nenhum outro fator importante é mantido constante.

É possível afirmar que o impacto que o FUNDEF teve sobre a política local de educação foi maior que o impacto do FUNDEB. O FUNDEF criou novos estímulos e constrangimentos à política de educação dos governos subnacionais tendo como prioridade a expansão do ensino fundamental. O FUNDEB basicamente se aproveitou dos mecanismos estabelecidos pelo primeiro e expandiu estes estímulos e constrangimentos para toda a educação básica. Desta forma, o impacto do FUNDEF foi maior porque ele estabeleceu constrangimentos sobre a política de educação dos 
governos subnacionais onde antes eles não existiam. Soma-se a isto o fato de que estes constrangimentos foram mantidos pelo FUNDEB. Por exemplo, o primeiro estabeleceu que $60 \%$ dos repasses do Fundo deveriam ser destinados ao salário dos professores atuantes no ensino fundamental, enquanto o segundo estabeleceu que este mesmo percentual dos repasses deveria ser destinado ao salário dos professores atuantes na educação básica. O primeiro significou a elevação do salário de professores do ensino fundamental, enquanto o segundo não necessariamente implicou que todos os professores da educação básica recebessem aumento, uma vez que seria possível que os prefeitos continuassem direcionando $60 \%$ dos recursos do Fundo apenas para o salário dos professores atuantes no ensino fundamental.

Outra contribuição importante desta pesquisa foi a constatação da importância que o partido do governador pode ter para a política local de educação. Enquanto estudos anteriores já mostraram que os governadores podem influenciar na agenda de educação dos municípios (ARRETCHE, 2000; GOMES, 2009), neste estudo foi mostrado que o partido do governador também pode ser importante para que se entenda a política local de educação. A relação entre partido do governador e política local de educação tende a ser inconstante ao longo do tempo. O comportamento desta relação sugere que há fatores contextuais importantes que não foram observados e que influenciam a forma como o partido do governador orienta sua política e se relaciona com as redes municipais de ensino.

Por fim, o modelo teórico desenvolvido no capítulo 3 se mostrou útil para interpretar os resultados apresentados. Ele estabeleceu a importância de que elementos contextuais fossem controlados como parte do conjunto de fatores que podem influenciar o cálculo dos prefeitos sobre os benefícios e custos da implementação de determinadas políticas. 


\title{
CONSIDERAÇÕES FINAIS
}

\begin{abstract}
"When you are studying any matter, or considering any philosophy, ask yourself only what are the facts and what is the truth that the facts bear out. Never let yourself be diverted either by what you wish to believe, or by what you think would have beneficent social effects if it were believed. But look only, and solely, at what are the facts"
\end{abstract}

(Bertrand Russell)

Esta dissertação examinou as políticas de expansão do acesso ao ensino e os gastos nos governos municipais brasileiros para analisar a extensão em que a filiação partidária dos prefeitos afetou a política local de educação no Brasil nos anos recentes.

Para esta finalidade, foi elaborado um modelo formal orientado a traduzir o comportamento esperado dos prefeitos e seus respectivos partidos políticos em relação à implementação de políticas públicas, uma vez que sejam atendidas certas condições. A intenção do modelo é servir de guia interpretativo para análises voltadas para o tema destacando fatores que estudos anteriores não deram a devida atenção - por exemplo, a coerência programática de um prefeito em relação às preferências de seus respectivos partidos deve ser investigada levando-se sempre em consideração os custos e estímulos para a adoção de determinadas políticas. Como foi demonstrado, a demanda por políticas deve sempre ser levada em consideração nessas análises. O modelo também sintetiza parte considerável das principais proposições existentes na literatura a respeito da influência dos partidos políticos sobre as políticas públicas.

A principal conclusão deste trabalho é que os partidos dos prefeitos não influenciam a política de educação dos municípios brasileiros. Em parte, isto se deve ao fato de que o comportamento dos prefeitos revela que sua principal motivação é atender a demanda por vagas. Em todos os níveis de ensino, a existência de demanda implicou a expansão da rede municipal de ensino, independentemente do partido do prefeito. Quando a tendência é de que os prefeitos reajam positivamente à demanda por vagas, é difícil que os partidos se destaquem uns dos outros, pois todos tendem a se mover na mesma direção. Seriam necessárias preferências intensas e forte coordenação para que 
ocorresse uma distinção do comportamento dos partidos políticos no atendimento à demanda por vagas.

O crescimento da rede estadual ou da rede particular de ensino tende a afetar negativamente a expansão da rede municipal. Ao alterar os custos e benefícios dos prefeitos em expandir suas redes de ensino, a concorrência com outras redes de serviços afeta a expansão da rede municipal de ensino.

É possível afirmar que o impacto que o FUNDEF teve sobre a política local de educação foi maior que o impacto do FUNDEB. O FUNDEF criou novos estímulos e constrangimentos à política de educação dos governos subnacionais tendo como prioridade a expansão do ensino fundamental. O FUNDEB basicamente se aproveitou dos mecanismos estabelecidos pelo primeiro e expandiu estes estímulos e constrangimentos para toda a educação básica. Desta forma, o impacto do FUNDEF foi maior porque ele estabeleceu constrangimentos sobre a política de educação dos governos subnacionais em um contexto em que estes não existiam. Soma-se a isto o fato de que estes constrangimentos foram mantidos pelo FUNDEB. Por exemplo, o primeiro estabeleceu que $60 \%$ dos repasses do Fundo deveriam ser destinados ao salário dos professores atuantes no ensino fundamental, enquanto o segundo estabeleceu que este mesmo percentual dos repasses deveria ser destinado ao salário dos professores atuantes na educação básica. O primeiro significou a elevação do salário de professores do ensino fundamental, enquanto o segundo não necessariamente implicou que todos os professores da educação básica recebessem aumento, uma vez que seria possível que os prefeitos continuassem direcionando $60 \%$ dos recursos do Fundo apenas para o salário dos professores atuantes no ensino fundamental.

A implementação da política de educação pelos governos subnacionais brasileiros não está diretamente associada à agenda dos partidos políticos na arena federal. Os partidos políticos não seguem uma agenda única quando comparamos suas políticas de educação na arena federal com suas políticas de educação no plano local. O objetivo de fazer com que o acesso ao ensino fundamental se universalizasse foi a motivação para a criação do FUNDEF pelo governo federal do PSDB. Posteriormente, esta mesma motivação para que isto também ocorresse com o acesso à educação básica pelo governo federal do PT 
deu origem ao FUNDEB. Entretanto, estas ações protagonizadas na arena federal não encontraram reflexo claro na agenda dos prefeitos e governadores destes partidos.

Como foi mostrado neste trabalho, ainda que as políticas dos governos estaduais afetem as políticas municipais e os governadores de um mesmo partido tendam a adotar estratégias semelhantes, a relação entre o partido do governador e política local de educação tende a ser inconstante ao longo do tempo. O comportamento desta relação sugere que há fatores contextuais importantes que não foram observados e que influenciam a forma como o partido do governador orienta sua política e se relaciona com as redes municipais de ensino.

Uma das principais conclusões deste trabalho é que estudos sobre a relação entre partidos políticos e políticas públicas devem ser orientados para que se entenda melhor quais são os fatores que fazem com que os primeiros sejam mais ou menos influentes sobre a implementação de políticas públicas. Entender melhor quais são os mecanismos que estimulam e inibem a influência dos partidos sobre políticas e como os partidos se comportam diante de tais mecanismos são pontos centrais nesta agenda de pesquisa para qual este trabalho deu sua modesta contribuição. 


\section{Referências Bibliográficas}

AGUIAR, Márcia Angela Da S. Avaliação do Plano Nacional de Educação 2001-2009: Questões para Reflexão. Educação \& Sociedade, v. 31, n. 112, p. 707-727, 2010.

ALDRICH, John. Why Parties? The Origin and Transformation of Political Parties in America. Chicago: University of Chicago Press, 1995.

ALT, James E. Political Parties, World Demand, and Unemployment: Domestic and International Sources of Economic Activity. v. 79, n. 4, p. 1016-1040, 2010.

ARRETCHE, Marta. Continuidades e descontinuidades da federação brasileira: de como 1988 facilitou 1995. Dados, v. 52, n. 2, p. 377-423, 2009.

- Estado Federativo e Políticas Sociais: Determinantes da Descentralização. Rio de Janeiro: Revan, 2000.

. Federalismo e igualdade territorial: uma contradição em termos?

Dados, v. 53, p. 587-620, 2010.

. Relações Federativas nas Politicas Sociais. Educação \& Sociedade, v. 23, n. 80, p. 25-48, 2002.

BRASIL. Congresso Nacional. Câmara dos Deputados. Diário da Câmara dos Deputados, Brasília, ano 51, n. 109, 19 de junho de 1996, p.17534. Disponível em: <http://imagem.camara.gov.br/Imagem/d/pdf/DCD19JUN1996. pdf\#page=90 >.

Acesso em: 23/10/2011. Discurso do deputado Elias Abrahão.

. Congresso Nacional. Câmara dos Deputados. Diário da Câmara dos Deputados, Brasília, ano 55, n. 108, 15 de junho de 2000, p.31505. Disponível em: <http://imagem.camara.gov.br/Imagem/d/pdf/DCD15JUN2000. pdf\#page=275>. Acesso em: 23/10/2011. Discurso do deputado Professor Luizinho.

. Congresso Nacional. Câmara dos Deputados. Diário da Câmara dos Deputados, Brasília, ano 61, n. 13, 25 de janeiro de 2006a, p.3733. Disponível em: <http://imagem.camara.gov.br/Imagem/d/pdf/DCD25JAN2006.pdf\#page=257>. Acesso em: 23/10/2011. Discurso do deputado Paulo Rubem Santiago.

. Congresso Nacional. Câmara dos Deputados. Diário da Câmara dos Deputados, Brasília, ano 61, n. 13, 25 de janeiro de 2006b, p.3741. Disponível em: <http://imagem.camara.gov.br/Imagem/d/pdf/DCD25JAN2006.pdf\#page=265>. Acesso em: 23/10/2011. Discurso do deputado Luiz Carlos Hauly.

Congresso Nacional. Câmara dos Deputados. Diário da Câmara dos Deputados, Brasília, ano 61, n. 13, 25 de janeiro de 2006c, p.3811. Disponível em: <http://imagem.camara.gov.br/Imagem/d/pdf/DCD25JAN2006.pdf\#page=335>. Acesso em: 23/10/2011. Discurso da deputada Almerinda de Carvalho. 
. Congresso Nacional. Câmara dos Deputados. Diário da Câmara dos Deputados, Brasília, ano 51, n. 80, 08 de maio de 2006d, p.12797. Disponível em: <http://imagem.camara.gov.br/Imagem/d/pdf/DCD08MAI1996.pdf\#page=165>. Acesso em: 23/10/2011. Discurso do deputado Ivan Valente.

. Congresso Nacional. Câmara dos Deputados. Diário da Câmara dos Deputados, Brasília, ano 61, n. 206, 07 de dezembro de 2006e, p.54153. Disponível em:

<http://imagem.camara.gov.br/Imagem/d/pdf/DCD07DEZ2006.pdf\#page=121>. Acesso em: 23/10/2011. Discurso do deputado Osmar Terra.

BOIX, Carles. Political Parties, Growth and Equality: Conservative and Social Democratic Strategies in the World Economy. New York: Cambridge University Press, 1998.

CAMPOS, Bruno Cesar; CRUZ, Breno De Paula Andrade. Impactos do Fundeb Sobre a Qualidade do Ensino Básico Público: Uma Análise Para os Municípios do Estado do Rio de Janeiro. Revista de Administração Pública, v. 43, n. 2, p. 371-393, 2009.

CASTLES, Francis; OBINGER, Herbert. Social expenditure and the politics of redistribution. Journal of European Social Policy, v. 17, n. 3, p. 206-222, 1 ago. 2007.

CAVALCANTE, Pedro. Os Partidos de Fato Fazem Diferença? Uma Análise do Desempenho Fiscal dos Municípios Brasileiros. 35 Encontro Anual da Anpocs, 2011.

COSTA, Bruno Lazzarotti Diniz; DUARTE, Vanda Catarina. Os Efeitos do Fundef nas Políticas Educacionais dos Municípios Mineiros. Educação em Revista, n. 48, p. 143170, 2008.

DOWNS, Anthony. An Economic Theory of Political Action in a Democracy. Journal of Political Economy, v. 65, p. 135-150, 1957.

DUARTE, Marisa Ribeiro Teixeira. Regulação Sistêmica e Política De Financiamento da Educação Básica. Educação \& Sociedade, v. 26, n. 92, p. 821-839, 2005.

DUVERGER, Maurice. Os Partidos Políticos. Brasília: UnB, 1980.

ENGLE, Robert; GRANGER, Clive. Co-Integration and Error Correction: Representation, Estimation, and Testing. Econometrica, v. 55, n. 2, p. 251-276, 1987.

ESPING-ANDERSEN, Gosta. As Três Economias Políticas do Welfare State. Lua Nova, v. 24, n. set, p. 85-116, 1991.

FRY, Brian R; WINTERS, Richard F. The Politics of Redistribution. American Political Science Review, v. 64, n. 2, p. 508-522, 1970.

GARRETT, Geoffrey; LANGE, Peter. Political responses to interdependence: what's "left" for the left? International Organization, v. 45, n. 4, p. 539-564, 1991. 
GERBER, Elisabeth R; HOPKINS, Daniel J. When Mayors Matter: Estimating the Impact of Mayoral Partisanship on City Policy. American Journal of Political Science, v. 55, n. 2, p. 326-339, 2011.

GOMES, Sandra. Políticas Nacionais e Implementação Subnacional: Uma Revisão da Descentralização Pós-Fundef. Dados, v. 52, n. 3, p. 659-690, 2009.

GREER, Scott L. The Politics of Divergent Policy. In: GREER, SCOTT L (Org.). . Territory, Democracy and Justice: Regionalism and Federalism in Western Democracies. [S.I.]: Palgrave Macmillan, 2005. p. 157-174.

HIBBS, Douglas A. Political Parties and Macroeconomic Policy. American Political Science Review, v. 71, n. 4, p. 1467-1487, 1977.

HOFFERBERT, Richard I. The Relation between Public Policy and Some Structural and Environmental Variables in the American States. American Political Science Review, v. 60, n. 1, p. 73-82, 1966.

HOFSTADTER, Richard. The Idea of a Party System. Berkeley: University of California Press, 1969.

IMBEAU, LM; ÉTRY, François; LAMARI, Moktar. Left-right party ideology and government policies: A meta-analysis. European Journal of Political Research, v. 40, n. 1, p. 1-29, 2001.

IZUMI, Maurício. Os determinantes do comportamento parlamentar no senado brasileiro (1989-2010). Dissertação (Mestrado). Programa de pós graduação em Ciência Política. Departamento de Ciência Política, Universidade de São Paulo. 2013.

KATZ, R. S.; MAIR, P. Changing Models of Party Organization and Party Democracy: The Emergence of the Cartel Party. Party Politics, v. 1, n. 1, p. 5-28, 1 jan. 1995.

KIRCHHEIMER, Otto. A Transformação dos Sistemas Partidários da Europa Ocidental. Revista Brasileira de Ciência Política, n. 7, p. 349-385, 2012.

KRASA, Stefan; POLBORN, Mattias K. Competition Between Specialized Candidates. American Political Science Review, v. 104, n. 4, p. 745-765, 2010.

LAVER, Michael; SCHOFIELD, Norman. Multiparty Government: The Politics of Coalition in Europe. [S.I.]: University of Michigan Press, 1998. p. 308

LEONI, Eduardo. Ideologia, democracia e comportamento parlamentar: a câmara dos deputados (1991-1998). Dados, v. 45, n. 3, p. 361-386, 2002.

LIMONGI, Fernando; CORTEZ, Rafael. As eleições de 2010 e o quadro partidário. Novos Estudos, v. 88, n. Dezembro, p. 21-37, 2010. 
LIPSET, Seymour Martin; ROKKAN, Stein. Party systems and voter alignments: Crossnational perspectives. Toronto: The Free Press, 1967. p. 554

MENEZES-FILHO, Naércio; PAZELLO, E. Does Money in Schools Matter? Evaluating the Effects of a Funding Reform on Wages and Test Scores in Brazil. Disponível em: $<$ http://www.econ.puc-rio.br/pdf/seminario/2004/fundef3.pdf>. Acesso em 02/02/14.

MICHELS, Robert. Os Partidos Políticos. São Paulo: Editora Senzala, 1982.

NEIVA, Pedro. Coesão e disciplina partidária no senado federal. Dados, v. 54, n. 1, p. 289-318, 2011.

OBINGER, H.; LIEBFRIED, S.; CASTLES, F. Federalism and The Welfare State: New World and European Experiences. Cambridge: Cambridge University Press, 2005.

OLIVEIRA, Romualdo Luiz Portela De. Direito à Educação e Federalismo no Brasil. Revista Retratos da Escola, v. 6, n. 10, p. 39-47, 2012.

PERSSON, Torsten; SVENSSON, Lars E O. Why a Stubborn Conservative would Run a Deficit: Policy with Time- Inconsistent. The Quarterly Journal of Economics, v. 104, n. 2, p. 325-345, 1989.

PIERSON, Paul. Politics in Time: History, Institutions, and Social Analysis. [S.I.]: Princeton University Press, 2004.

PINTO, José Marcelino De Rezende. A Política Recente De Fundos Para O Financiamento Da Educação E Seus Efeitos No Pacto Federativo. Educação \& Sociedadea, v. 28, n. 100, p. 877-897, 2007.

PINTO, José Marcelino de Rezende. Financiamento da Educação no Brasil: Um Balanço do Governo FHC (1995-2002). Educaçao \& Sociedade, v. 23, n. 80, p. 108-135, 2002.

RIBEIRO, Leandro Molhano. Partidos e Políticas Sociais nos Municípios Brasileiros (19962003). 2005. IUPERJ. Rio de Janeiro, 2005.

RODRIGUES, Gilmar. Democracia e Partidos Políticos: os gastos publicos municipais como instrumento de análise politico-ideológico. In: HOCHMAN, GILBERTO; ARRETCHE, MARTA; MARQUES, EdUARdo (Org.). . Políticas Públicas no Brasil. Rio de Janeiro: Fiocruz, 2007. p. 275-302.

RODRIGUEZ, Vicente. Financiamento da Educaçao e Politicas Públicas: O Fundef e a Politica de Descentralizaçao. Cadernos CEDES, n. 55, p. 42-57, 2001.

ROSE, Richard. Do Parties Make a Difference?. 2nd Revise ed. [S.I.]: Palgrave Macmillan, 1984. 
ROSE, Richard. Inheritance Before Choice in Public Policy. Journal of Theoretical Politics, v. 2, n. 3, p. 263-291, 1990.

SAÉZ, Lawrence; SINHA, Aseema. Political Cycles, Political Institutions and Public Expenditure in India, 1980-2000. British Journal of Political Science., v. 40, n. 1, p. 91113, 2010.

SÁTYRO, Natália Guimarães Duarte. Política e Instituições e a Dinâmica das Políticas Sociais nos Estados Brasileiros Uma Análise após a Redemocratização. 2008. IUPERJ/UCAM, 2008.

SCHATTSCHNEIDER, Elmer. Party Government. New York: Rinehart, 1942.

SCHMIDT, Manfred G. When Parties Matter: A Review of the Possibilities and Limits of Partisan Influence on Public Policy. European Journal of Political Research, v. 30, n. 2, p. 155-183, 1996.

SOUZA, Donaldo Bello De; FARIA, Lia Ciomar Macedo De. Reforma do Estado, Descentralização e Municipalização do Ensino no Brasil: A Gestão Política dos Sistemas Públicos de Ensino Pós-LDB 9.394/96. Ensaio: Avaliação e Políticas Públicas em Educação, v. 12, n. 45, p. 925-944, 2004.

STOKES, Donald E. Spatial Models of Party Competition. American Political Science Review, v. 57, n. 2, p. 368-377, 1963.

TURNER, Ed. Political Parties and Public Policy in the German Länder: When Parties Matter. New York: Palgrave Macmillan, 2011. p. 272

VAZQUEZ, Daniel Arias. Desequilíbrios Regionais no Financiamento da Educaçao: A Politica Nacional de Equidade do Fundef. Revista de Sociologia e Política, n. 24, p. 149-164, 2005.

WHITTEN, Guy; WILLIAMS, Laron. Buttery Guns and Welfare Hawks: The Politics of Defense Spending in Advanced Industrial Democracies. American Journal of Political Science, v. 55, n. 1, p. $117-134,2011$.

WILENSKI, Harold. The Welfare State and Equality. Berkeley: University of California Press, 1975.

WINTERS, Richard. Party Control and Policy Change. American Journal of Political Science, v. 20, n. 4, p. 597-636, 1976. 


\section{APÊNDICE A: ESTATÍSTICAS DESCRITIVAS DAS VARIÁVEIS UTILIZADAS NOS MODELOS DE REGRESSÃO}

Nesta seção são apresentadas estatísticas descritivas das variáveis utilizadas em todos os modelos apresentados neste trabalho para todos os municípios com até 50 mil moradores.

Tabela A1: Estatísticas descritivas das variáveis utilizadas nos modelos de regressão

\begin{tabular}{|c|c|c|c|c|c|c|c|}
\hline Variável & Período & Obs. & Mediana & Média & DP. & Min. & Max. \\
\hline \multirow{3}{*}{$\begin{array}{c}\text { Vagas criadas nas creches } \\
\text { municipais }\end{array}$} & 2000-2004 & 4439 & 0,00 & 12,12 & 73,05 & -1189 & 660 \\
\hline & 2004-2008 & 4095 & 0,00 & 15,66 & 74,00 & -999 & 567 \\
\hline & 2008-2012 & 3829 & 9,00 & 27,14 & 70,98 & -356 & 700 \\
\hline \multirow{3}{*}{$\begin{array}{c}\text { Vagas criadas nas creches } \\
\text { estaduais }\end{array}$} & $2000-2004$ & 4952 & 0,00 & $-0,18$ & 6,61 & -190 & 120 \\
\hline & 2004-2008 & 4975 & 0,00 & $-0,13$ & 6,20 & -333 & 81 \\
\hline & 2008-2012 & 4950 & 0,00 & $-0,05$ & 3,36 & -81 & 156 \\
\hline \multirow{3}{*}{$\begin{array}{c}\text { Vagas criadas nas creches } \\
\text { particulares }\end{array}$} & $2000-2004$ & 4952 & 0,00 & 5,77 & 43,32 & -444 & 694 \\
\hline & 2004-2008 & 4975 & 0,00 & 0,49 & 47,48 & -1010 & 461 \\
\hline & 2008-2012 & 4950 & 0,00 & 1,65 & 33,16 & -543 & 294 \\
\hline \multirow{3}{*}{$\begin{array}{l}\text { Vagas criadas nas pré } \\
\text { escolas municipais }\end{array}$} & $2000-2004$ & 4259 & 19,00 & 40,63 & 162,14 & -1268 & 1662 \\
\hline & 2004-2008 & 4051 & $-16,00$ & $-33,65$ & 155,98 & -1276 & 1193 \\
\hline & 2008-2012 & 3924 & $-3,00$ & $-21,96$ & 132,06 & -1237 & 558 \\
\hline \multirow{3}{*}{$\begin{array}{c}\text { Vagas criadas nas pré } \\
\text { escolas estaduais }\end{array}$} & $2000-2004$ & 4952 & 0,00 & $-4,61$ & 38,78 & -457 & 486 \\
\hline & 2004-2008 & 4975 & 0,00 & $-12,44$ & 44,63 & -535 & 165 \\
\hline & 2008-2012 & 4950 & 0,00 & $-4,34$ & 24,12 & -420 & 108 \\
\hline \multirow{3}{*}{$\begin{array}{l}\text { Vagas criadas nas pré } \\
\text { escolas particulares }\end{array}$} & $2000-2004$ & 4952 & 0,00 & 15,14 & 55,68 & -519 & 707 \\
\hline & 2004-2008 & 4975 & 0,00 & $-11,42$ & 63,87 & -1156 & 616 \\
\hline & 2008-2012 & 4950 & 0,00 & $-1,22$ & 38,63 & -648 & 338 \\
\hline \multirow{3}{*}{$\begin{array}{l}\text { Vagas criadas no ensino } \\
\text { fundamental municipal }\end{array}$} & $2000-2004$ & 4838 & 2,00 & 71,43 & 511,75 & -7521 & 5909 \\
\hline & 2004-2008 & 4755 & $-53,00$ & $-173,75$ & 515,80 & -6759 & 3532 \\
\hline & 2008-2012 & 4684 & $-71,00$ & $-122,82$ & 338,99 & -3607 & 2927 \\
\hline \multirow{3}{*}{$\begin{array}{l}\text { Vagas criadas no ensino } \\
\text { fundamental estadual }\end{array}$} & $2000-2004$ & 4952 & $-110,50$ & $-234,56$ & 470,30 & -5998 & 6773 \\
\hline & 2004-2008 & 4975 & $-79,00$ & $-162,61$ & 301,67 & -4802 & 1508 \\
\hline & 2008-2012 & 4950 & $-84,00$ & $-148,00$ & 237,66 & -3839 & 1208 \\
\hline \multirow{3}{*}{$\begin{array}{l}\text { Vagas criadas no ensino } \\
\text { fundamental particular }\end{array}$} & $2000-2004$ & 4952 & 0,00 & 11,85 & 84,39 & -1017 & 1565 \\
\hline & 2004-2008 & 4975 & 0,00 & 19,61 & 70,80 & -891 & 701 \\
\hline & 2008-2012 & 4950 & 0,00 & 10,93 & 67,82 & -667 & 849 \\
\hline \multirow{3}{*}{$\begin{array}{c}\text { Demanda por vagas em } \\
\text { creches (\%) }\end{array}$} & 2000 & 4899 & 96,93 & 91,89 & 12,36 & $-40,82$ & 100 \\
\hline & 2004 & 4439 & 93,02 & 89,51 & 12,69 & $-8,82$ & 100 \\
\hline & 2008 & 4095 & 89,38 & 86,77 & 12,80 & $-1,28$ & 100 \\
\hline
\end{tabular}


Tabela A20: Continuação

\begin{tabular}{|c|c|c|c|c|c|c|c|}
\hline Variável & Período & Obs. & Mediana & Média & DP. & Min. & Max. \\
\hline \multirow{3}{*}{$\begin{array}{c}\text { Demanda por vagas em pré } \\
\text { escolas }(\%)\end{array}$} & 2000 & 4825 & 56,48 & 54,83 & 24,24 & $-79,25$ & 100 \\
\hline & 2004 & 4259 & 50,00 & 48,51 & 22,94 & $-99,66$ & 100 \\
\hline & 2008 & 4051 & 53,18 & 51,50 & 20,19 & $-51,67$ & 100 \\
\hline \multirow{3}{*}{$\begin{array}{l}\text { Demanda por vagas em } \\
\text { ensino fundamental (\%) }\end{array}$} & 2000 & 4960 & $-30,14$ & $-34,46$ & 24,10 & $-245,87$ & 50 \\
\hline & 2004 & 4838 & $-21,32$ & $-24,81$ & 23,94 & $-212,98$ & 51,70 \\
\hline & 2008 & 4755 & $-26,17$ & $-27,72$ & 17,06 & $-267,57$ & 70,75 \\
\hline \multirow{3}{*}{$\begin{array}{c}\text { Pop. em idade ideal para as } \\
\text { creches (\%) }\end{array}$} & 2000 & 4982 & 7,69 & 7,93 & 1,79 & 3,21 & 17,42 \\
\hline & 2004 & 5004 & 7,68 & 7,92 & 1,79 & 3,27 & 17,44 \\
\hline & 2008 & 4979 & 6,93 & 7,10 & 1,87 & 2,56 & 17,01 \\
\hline \multirow{3}{*}{$\begin{array}{l}\text { Pop. em idade ideal para as } \\
\text { pré escolas (\%) }\end{array}$} & 2000 & 4982 & 6,27 & 6,38 & 1,22 & 3,02 & 12,36 \\
\hline & 2004 & 5004 & 6,26 & 6,38 & 1,22 & 2,88 & 12,35 \\
\hline & 2008 & 4979 & 3,63 & 3,71 & 0,82 & 1,55 & 7,96 \\
\hline \multirow{3}{*}{$\begin{array}{l}\text { Pop. em idade ideal para o } \\
\text { ensino fundamental (\%) }\end{array}$} & 2000 & 4982 & 17,27 & 17,46 & 2,66 & 10,20 & 26,75 \\
\hline & 2004 & 5004 & 17,26 & 17,44 & 2,67 & 10,28 & 26,74 \\
\hline & 2008 & 4979 & 16,05 & 16,26 & 2,84 & 8,05 & 32,29 \\
\hline \multirow{3}{*}{ Receita per capita média } & 2001-2004 & 4889 & 11,22 & 13,53 & 17,21 & 3,59 & 803,33 \\
\hline & $2005-2008$ & 4939 & 15,00 & 17,66 & 9,40 & 5,71 & 154,64 \\
\hline & 2009-2012 & 4796 & 19,02 & 22,17 & 12,40 & 8,52 & 460,35 \\
\hline \multirow{3}{*}{ Gasto com pessoal (\%) } & 2000 & 4775 & 38,16 & 38,86 & 10,32 & 0,00 & 99,43 \\
\hline & 2004 & 4545 & 42,93 & 42,82 & 8,21 & 0,41 & 78,80 \\
\hline & 2008 & 4873 & 41,94 & 42,15 & 7,85 & 2,15 & 100,00 \\
\hline \multirow{3}{*}{$\begin{array}{l}\text { Gasto médio (\%) dos } \\
\text { governadores em educação }\end{array}$} & 2001-2004 & 5004 & 18,33 & 18,40 & 3,18 & 9,62 & 25,21 \\
\hline & $2005-2008$ & 4979 & 14,34 & 15,15 & 3,23 & 10,18 & 21,62 \\
\hline & 2009-2012 & 4951 & 14,52 & 15,08 & 3,69 & 9,14 & 24,80 \\
\hline $\begin{array}{c}\text { Gasto médio (\%) dos } \\
\text { governadores em ensino } \\
\text { fundamental }\end{array}$ & 2009-2012 & 4951 & 31,35 & 36,32 & 19,80 & 0,66 & 91,75 \\
\hline \multirow{3}{*}{$\begin{array}{l}\text { Média de Transferências do } \\
\text { FUNDEF/FUNDEB }\end{array}$} & 2001-2004 & 3426 & 1378728,00 & 1942573,00 & 1813714,00 & 0 & 16200000,00 \\
\hline & $2005-2008$ & 2832 & 2080705,00 & 3002992,00 & 2739996,00 & 0 & 23200000,00 \\
\hline & 2009-2012 & 2573 & 3156683,00 & 4582991,00 & 4189625,00 & 0 & 28800000,00 \\
\hline \multirow{2}{*}{$\begin{array}{c}\text { Crescimento das creches } \\
\text { municipais }\end{array}$} & 2004 & 5004 & 0,00 & 0,46 & 0,50 & 0 & 1 \\
\hline & 2008 & 4979 & 0,00 & 0,45 & 0,50 & 0 & 1 \\
\hline \multirow{2}{*}{$\begin{array}{l}\text { Crescimento das pré- } \\
\text { escolas municipais }\end{array}$} & 2004 & 5004 & 1,00 & 0,62 & 0,48 & 0 & 1 \\
\hline & 2008 & 4979 & 0,00 & 0,35 & 0,48 & 0 & 1 \\
\hline \multirow{2}{*}{$\begin{array}{l}\text { Crescimento do ensino } \\
\text { fundamental municipal }\end{array}$} & 2004 & 5004 & 1,00 & 0,50 & 0,50 & 0 & 1 \\
\hline & 2008 & 4979 & 0,00 & 0,31 & 0,46 & 0 & 1 \\
\hline \multirow{3}{*}{ Continuidade } & 2001-2004 & 5004 & 0,00 & 0,35 & 0,48 & 0 & 1 \\
\hline & $2005-2008$ & 4979 & 0,00 & 0,28 & 0,45 & 0 & 1 \\
\hline & 2009-2012 & 4951 & 0,00 & 0,36 & 0,48 & 0 & 1 \\
\hline \multirow{3}{*}{$\begin{array}{l}\text { Distância entre eleito e } \\
\text { segundo mais votado }\end{array}$} & 2001-2004 & 4998 & 12,30 & 18,51 & 20,11 & 0 & 100 \\
\hline & $2005-2008$ & 4975 & 10,41 & 15,62 & 17,91 & 0 & 100 \\
\hline & 2009-2012 & 4943 & 11,43 & 19,49 & 23,56 & 0 & 100 \\
\hline
\end{tabular}


Tabela A1: Continuação

\begin{tabular}{|c|c|c|c|c|c|c|c|}
\hline Variável & Período & Obs. & Mediana & Média & DP. & Min. & Max. \\
\hline \multirow{3}{*}{ Antecedido pelo PSDB } & 2001-2004 & 5004 & 0,00 & 0,16 & 0,37 & 0 & 1 \\
\hline & $2005-2008$ & 4979 & 0,00 & 0,18 & 0,38 & 0 & 1 \\
\hline & 2009-2012 & 4951 & 0,00 & 0,15 & 0,36 & 0 & 1 \\
\hline \multirow{3}{*}{ Antecedido pelo PT } & 2001-2004 & 5004 & 0,00 & 0,02 & 0,13 & 0 & 1 \\
\hline & $2005-2008$ & 4979 & 0,00 & 0,02 & 0,16 & 0 & 1 \\
\hline & 2009-2012 & 4951 & 0,00 & 0,07 & 0,25 & 0 & 1 \\
\hline \multirow{3}{*}{ Governador do PMDB } & 2001-2004 & 5004 & 0,00 & 0,28 & 0,51 & 0 & 2 \\
\hline & $2005-2008$ & 4979 & 0,00 & 0,33 & 0,69 & 0 & 2 \\
\hline & 2009-2012 & 4951 & 0,00 & 0,13 & 0,40 & 0 & 2 \\
\hline \multirow{3}{*}{ Governador do PSDB } & 2001-2004 & 5004 & 0,00 & 0,62 & 0,80 & 0 & 2 \\
\hline & $2005-2008$ & 4979 & 0,00 & 0,62 & 0,80 & 0 & 2 \\
\hline & 2009-2012 & 4951 & 0,00 & 0,58 & 0,70 & 0 & 2 \\
\hline \multirow{3}{*}{ Governador do PT } & 2001-2004 & 5004 & 0,00 & 0,08 & 0,33 & 0 & 2 \\
\hline & $2005-2008$ & 4979 & 0,00 & 0,20 & 0,50 & 0 & 2 \\
\hline & 2009-2012 & 4951 & 0,00 & 0,28 & 0,62 & 0 & 2 \\
\hline \multirow{2}{*}{$\begin{array}{l}\text { Variação (\%) do gasto } \\
\text { médio em educação }\end{array}$} & $2002-2008$ & 4044 & $-1,02$ & $-5,40$ & 15,56 & $-80,63$ & 29,45 \\
\hline & 2005-2012 & 4180 & 1,35 & 1,46 & 4,22 & $-24,87$ & 28,22 \\
\hline \multirow{3}{*}{$\begin{array}{c}\text { Gasto (\%) médio em } \\
\text { educação }\end{array}$} & $2002-2004$ & 4382 & 29,54 & 33,44 & 15,58 & 6,84 & 99,88 \\
\hline & $2005-2008$ & 4556 & 26,79 & 28,05 & 7,40 & 1,88 & 62,35 \\
\hline & 2009-2012 & 4506 & 27,88 & 29,53 & 8,71 & 3,42 & 72,33 \\
\hline \multirow{3}{*}{$\begin{array}{l}\text { Média das matrículas na } \\
\text { rede municipal }\end{array}$} & 2001-2004 & 3593 & 1182,00 & 1891,54 & 2015,81 & 0 & 17180,33 \\
\hline & $2005-2008$ & 3234 & 1089,88 & 1730,82 & 1827,29 & 0 & 17066,25 \\
\hline & 2009-2012 & 3039 & 962,25 & 1514,00 & 1519,41 & 0 & 11967 \\
\hline \multicolumn{8}{|l|}{ Variação (\%) do gasto } \\
\hline \multirow{2}{*}{$\begin{array}{l}\text { Gasto (\%) médio em } \\
\text { educação infantil }\end{array}$} & $2005-2008$ & 4588 & 5,09 & 8,21 & 8,95 & 0 & 70,98 \\
\hline & 2009-2012 & 4531 & 7,51 & 10,65 & 10,49 & 0 & 65,93 \\
\hline \multirow{3}{*}{$\begin{array}{l}\text { Pop. idade ideal para o } \\
\text { ensino infantil (\%) }\end{array}$} & 2001-2004 & 4783 & 11,91 & 12,22 & 2,58 & 5,08 & 25,17 \\
\hline & $2005-2008$ & 4977 & 10,54 & 10,81 & 2,69 & 4,11 & 24,97 \\
\hline & 2009-2012 & 4951 & 8,71 & 8,97 & 2,14 & 2,81 & 23,09 \\
\hline \multirow{3}{*}{$\begin{array}{l}\text { Média de matrículas na } \\
\text { educação infantil municipal }\end{array}$} & 2001-2004 & 3681 & 244,00 & 369,17 & 366,14 & 0 & 3763 \\
\hline & $2005-2008$ & 3344 & 246,00 & 368,93 & 357,13 & 0 & 3134,25 \\
\hline & 2009-2012 & 3177 & 234,50 & 341,89 & 313,91 & 0 & 2353,25 \\
\hline \multirow{3}{*}{$\begin{array}{l}\text { Média de matrículas na } \\
\text { educação infantil estadual }\end{array}$} & 2001-2004 & 4783 & 0,00 & 21,14 & 61,96 & 0 & 716 \\
\hline & $2005-2008$ & 4817 & 0,00 & 11,71 & 41,45 & 0 & 730,25 \\
\hline & 2009-2012 & 4943 & 0,00 & 2,14 & 13,67 & 0 & 368,75 \\
\hline $\begin{array}{l}\text { Variação (\%) do gasto } \\
\text { médio em ensino } \\
\text { fundamental }\end{array}$ & 2005-2012 & 4224 & $-2,52$ & $-3,17$ & 14,08 & $-85,70$ & 87,27 \\
\hline \multirow{2}{*}{$\begin{array}{c}\text { Gasto (\%) médio em ensino } \\
\text { fundamental }\end{array}$} & $2005-2008$ & 4588 & 85,47 & 82,21 & 14,52 & 0 & 100 \\
\hline & 2009-2012 & 4531 & 81,85 & 79,16 & 15,85 & 0 & 100 \\
\hline
\end{tabular}


Tabela A1: Conclusão

\begin{tabular}{crrrrrrr}
\hline Variável & Período & Obs. & Mediana & Média & DP. & Min. & Max. \\
\hline & $2001-2004$ & 4626 & 1092,00 & 1830,71 & 2026,82 & 15805 \\
$\begin{array}{c}\text { Média de matrículas no } \\
\text { ensino fundamental } \\
\text { municipal }\end{array}$ & $2005-2008$ & 4604 & 1051,75 & 1708,96 & 1825,09 & 0 & 14495,75 \\
\hline $\begin{array}{c}\text { Média de matrículas no } \\
\text { ensino fundamental }\end{array}$ & $2009-2012$ & 4676 & 953,38 & 1513,78 & 1554,23 & 10863,25 \\
\hline estadual & $2001-2004$ & 4783 & 667,75 & 1001,95 & 1021,42 & 0 & 8508,25 \\
\hline
\end{tabular}

Fonte: Banco de Dados Matrículas e Gastos nos Municípios Brasileiros. 


\section{APÊNDICE B: MATRIZES DE CORRELAÇÃO DAS VARIÁVEIS UTILIZADAS NOS MODELOS DE REGRESSÃO}

\begin{tabular}{|c|c|c|c|c|c|c|c|c|c|c|c|c|c|c|c|c|}
\hline & $\begin{array}{l}\quad \text { Matriz } \\
\text { Vagas } \\
\text { criadas } \\
\text { nas } \\
\text { creches } \\
\text { municipais }\end{array}$ & $\begin{array}{l}\text { Gasto médio } \\
\text { (\%) dos } \\
\text { governadores } \\
\text { em educação }\end{array}$ & $\begin{array}{l}\text { ão das } \mathbf{V a} \\
\text { Vagas } \\
\text { criadas } \\
\text { nas } \\
\text { creches } \\
\text { estaduais } \\
\end{array}$ & $\begin{array}{l}\text { Vagas } \\
\text { criadas nas } \\
\text { creches } \\
\text { particulares }\end{array}$ & lizadas nos & $\begin{array}{l}\text { L4.Pop. } \\
\text { em idade } \\
\text { ideal (\%) }\end{array}$ & $\begin{array}{l}\text { Receita } \\
\text { per capita } \\
\text { média }\end{array}$ & $\begin{array}{l}\text { L4.Gasto } \\
\text { com } \\
\text { pessoal } \\
(\%)\end{array}$ & $\begin{array}{l}\text { Média de } \\
\text { Transferências } \\
\text { do FUNDEF/ } \\
\text { FUNDEB }\end{array}$ & $\begin{array}{l}\text { gas em C } \\
\text { Distância } \\
\text { entre } \\
\text { eleito e } \\
\text { segundo } \\
\text { mais } \\
\text { votado }\end{array}$ & $\begin{array}{l}\text { Governador } \\
\text { do PMDB }\end{array}$ & $\begin{array}{l}\text { Governador } \\
\text { do PSDB }\end{array}$ & $\begin{array}{l}\text { Governador } \\
\text { do PT }\end{array}$ & $\begin{array}{l}\text { Antecedido } \\
\text { pelo PSDB }\end{array}$ & $\begin{array}{l}\text { Antecedido } \\
\text { pelo PT }\end{array}$ & Continuidade \\
\hline $\begin{array}{l}\text { Vagas criadas nas creches municipais } \\
\text { Gasto médio (\%) dos governadores em } \\
\text { educação }\end{array}$ & $\begin{array}{r}1,0000 \\
-0,0956\end{array}$ & 1,0000 & & & & & & & & & & & & & & \\
\hline Vagas criadas nas creches estaduais & $-0,0328$ & $-0,0381$ & 1,0000 & & & & & & & & & & & & & \\
\hline Vagas criadas nas creches particulares & $-0,1561$ & $-0,0130$ & 0,0081 & 1,0000 & & & & & & & & & & & & \\
\hline L4.Demanda (\%) & 0,2103 & $-0,1453$ & 0,0534 & 0,0817 & 1,0000 & & & & & & & & & & & \\
\hline L4.Pop. em idade ideal (\%) & $-0,0005$ & $-0,0627$ & $-0,0021$ & $-0,0374$ & 0,1219 & 1,0000 & & & & & & & & & & \\
\hline Receita per capita média & 0,0003 & 0,0348 & 0,0013 & $-0,0341$ & $-0,1853$ & $-0,3096$ & 1,0000 & & & & & & & & & \\
\hline $\begin{array}{l}\text { L4.Gasto com pessoal (\%) } \\
\text { Média de Transferências do }\end{array}$ & 0,0197 & $-0,0817$ & 0,0466 & 0,0423 & 0,0189 & $-0,1193$ & $-0,0257$ & 1,0000 & & & & & & & & \\
\hline $\begin{array}{l}\text { FUNDEF/FUNDEB } \\
\text { Distância entre eleito e segundo mais } \\
\text { votado }\end{array}$ & 0,1121 & $-0,1632$ & 0,0656 & 0,1550 & 0,0555 & 0,3460 & $-0,2914$ & 0,1368 & 1,0000 & 1,0000 & & & & & & \\
\hline Governador do PSDB & $-0,0371$ & 0,4129 & $-0,0349$ & 0,0653 & $-0,0667$ & $-0,2032$ & 0,1195 & 0,0499 & $-0,0845$ & 0,0054 & $-0,4602$ & 1,0000 & & & & \\
\hline Governador do PT & $-0,0369$ & 0,1960 & $-0,0119$ & $-0,0086$ & $-0,0272$ & 0,1920 & $-0,0342$ & $-0,0990$ & 0,0228 & 0,0200 & $-0,1089$ & $-0,1933$ & 1,0000 & & & \\
\hline Antecedido pelo PSDB & $-0,0065$ & 0,1168 & 0,0081 & $-0,0166$ & $-0,0605$ & $-0,0145$ & 0,0252 & $-0,0001$ & 0,0219 & 0,0249 & $-0,1306$ & 0,2081 & $-0,0008$ & 1,0000 & & \\
\hline Antecedido pelo PT & $-0,0418$ & $-0,0277$ & 0,0023 & $-0,0165$ & $-0,0180$ & 0,0088 & $-0,0303$ & 0,0242 & $-0,0123$ & $-0,0413$ & 0,0053 & $-0,0250$ & 0,0263 & $-0,0588$ & 1,0000 & \\
\hline Continuidade & 0,0088 & 0,0785 & 0,0041 & $-0,0215$ & 0,0280 & 0,0103 & 0,0720 & $-0,1274$ & $-0,0322$ & 0,1347 & $-0,0271$ & $-0,0001$ & 0,0806 & 0,0297 & 0,0040 & 1,0000 \\
\hline
\end{tabular}

Fonte: Banco de Dados Matrículas e Gastos nos Municípios Brasileiros.

$\mathrm{N}=1993$ 


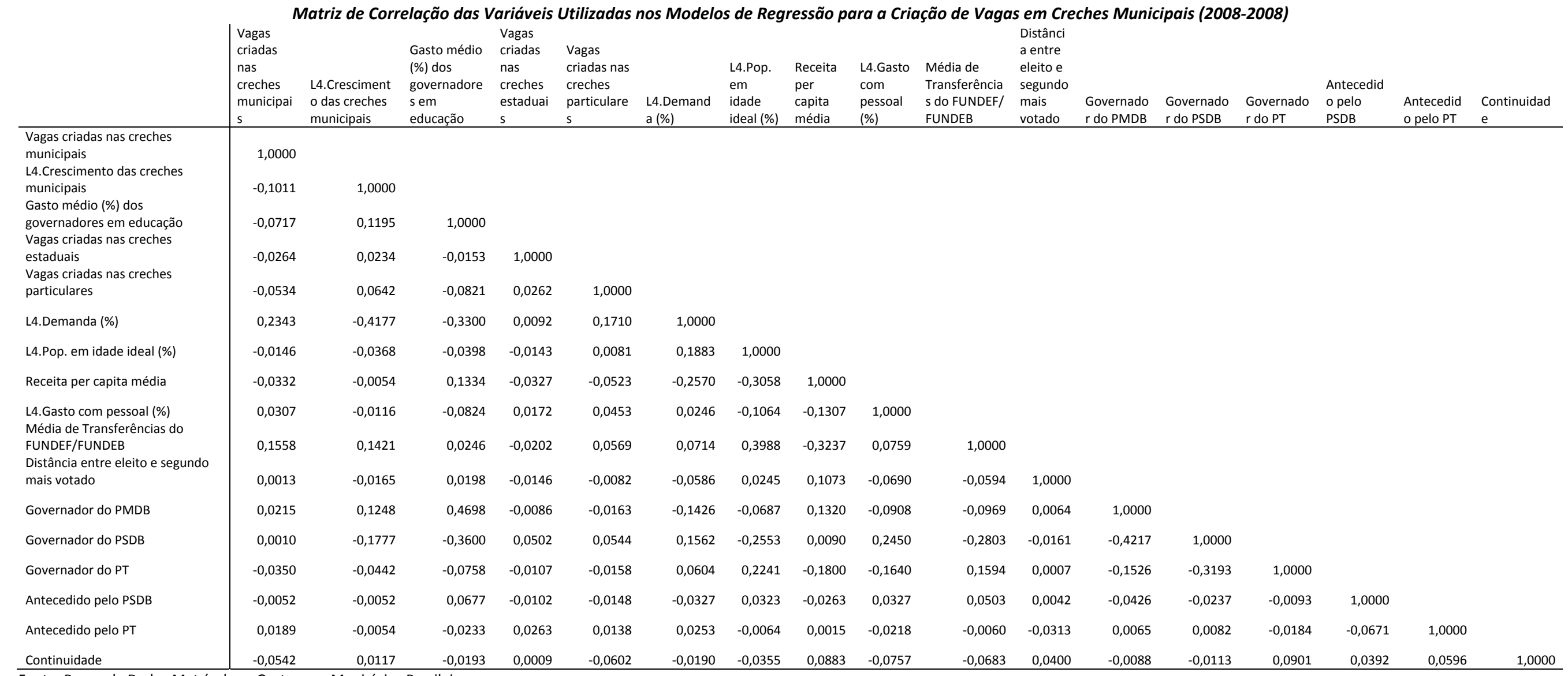

Fonte: Banco de Dados Matrículas e Gastos nos Municípios Brasileiros.

$\mathrm{N}=1993$ 
Matriz de Correlação das Variáveis Utilizadas nos Modelos de Regressão para a Criação de Vagas em Creches Municipais (2008-2012)

\begin{tabular}{|c|c|c|c|c|c|c|c|c|c|c|c|c|c|c|c|c|c|}
\hline & \multicolumn{17}{|c|}{ Matriz de Correlação das Variáveis Utilizadas nos Modelos de Regressão para a Criação de Vagas em Creches Municipais (2008-2012) } \\
\hline & $\begin{array}{l}\text { Vagas } \\
\text { criadas } \\
\text { nas } \\
\text { creches } \\
\text { municipai } \\
\mathrm{s}\end{array}$ & $\begin{array}{l}\text { L4.Cresciment } \\
\text { o das creches } \\
\text { municipais }\end{array}$ & $\begin{array}{l}\text { Gasto médio } \\
\text { (\%) dos } \\
\text { governadore } \\
\text { s em } \\
\text { educação }\end{array}$ & $\begin{array}{l}\text { Vagas } \\
\text { criadas } \\
\text { nas } \\
\text { creches } \\
\text { estaduai } \\
\mathrm{s}\end{array}$ & $\begin{array}{l}\text { Vagas } \\
\text { criadas nas } \\
\text { creches } \\
\text { particulare } \\
\mathrm{s}\end{array}$ & $\begin{array}{l}\text { L4.Demand } \\
\text { a (\%) }\end{array}$ & $\begin{array}{l}\text { L4.Pop. } \\
\text { em idade } \\
\text { ideal (\%) }\end{array}$ & $\begin{array}{l}\text { Receita } \\
\text { per } \\
\text { capita } \\
\text { média }\end{array}$ & $\begin{array}{l}\text { L4.Gasto } \\
\text { com } \\
\text { pessoal } \\
(\%)\end{array}$ & $\begin{array}{l}\text { Média de } \\
\text { Transferência } \\
\text { s do FUNDEF/ } \\
\text { FUNDEB }\end{array}$ & $\begin{array}{l}\text { Distância } \\
\text { entre } \\
\text { eleito e } \\
\text { segundo } \\
\text { mais } \\
\text { votado }\end{array}$ & $\begin{array}{l}\text { Governado } \\
\text { rdo PMDB }\end{array}$ & $\begin{array}{l}\text { Governado } \\
\text { rdo PSDB }\end{array}$ & $\begin{array}{l}\text { Governado } \\
\text { rdo PT }\end{array}$ & $\begin{array}{l}\text { Antecedid } \\
\text { o pelo } \\
\text { PSDB }\end{array}$ & $\begin{array}{l}\text { Antecedid } \\
\text { o pelo PT }\end{array}$ & $\begin{array}{l}\text { Continuidad } \\
\text { e }\end{array}$ \\
\hline $\begin{array}{l}\text { Vagas criadas nas creches } \\
\text { municipais } \\
\text { L4.Crescimento das creches }\end{array}$ & 1,0000 & & & & & & & & & & & & & & & & \\
\hline municipais & 0,0197 & 1,0000 & & & & & & & & & & & & & & & \\
\hline $\begin{array}{l}\text { Gasto médio (\%) dos } \\
\text { governadores em educação }\end{array}$ & 0,0311 & $-0,0094$ & 1,0000 & & & & & & & & & & & & & & \\
\hline $\begin{array}{l}\text { Vagas criadas nas creches } \\
\text { estaduais }\end{array}$ & $-0,0549$ & 0,0024 & $-0,0258$ & 1,0000 & & & & & & & & & & & & & \\
\hline $\begin{array}{l}\text { Vagas criadas nas creches } \\
\text { particulares }\end{array}$ & 0,0450 & 0,0407 & $-0,0076$ & $-0,0113$ & 1,0000 & & & & & & & & & & & & \\
\hline L4.Demanda (\%) & 0,0229 & $-0,3972$ & $-0,2267$ & 0,0104 & 0,0511 & 1,0000 & & & & & & & & & & & \\
\hline L4.Pop. em idade ideal (\%) & $-0,0635$ & $-0,0398$ & $-0,0520$ & 0,0050 & $-0,0254$ & 0,3094 & 1,0000 & & & & & & & & & & \\
\hline Receita per capita média & $-0,0103$ & $-0,0479$ & 0,0157 & 0,0332 & $-0,0136$ & $-0,2508$ & $-0,3543$ & 1,0000 & & & & & & & & & \\
\hline $\begin{array}{l}\text { L4.Gasto com pessoal (\%) } \\
\text { Média de Transferências do }\end{array}$ & $-0,0286$ & $-0,0056$ & $-0,0578$ & $-0,0531$ & 0,0151 & 0,1248 & 0,1807 & $-0,2393$ & 1,0000 & & & & & & & & \\
\hline segundo mais votado & 0,0108 & $-0,0050$ & 0,0189 & $-0,0209$ & 0,0311 & $-0,0052$ & 0,0121 & 0,0823 & $-0,0587$ & $-0,0065$ & 1,0000 & & & & & & \\
\hline Governador do PMDB & 0,0738 & 0,0507 & $-0,0656$ & 0,0098 & 0,0305 & 0,0356 & 0,1327 & 0,0520 & $-0,0422$ & 0,1214 & 0,0414 & 1,0000 & & & & & \\
\hline Governador do PSDB & 0,0982 & $-0,0307$ & 0,0090 & 0,0000 & 0,0176 & $-0,0831$ & $-0,1584$ & 0,1543 & $-0,0744$ & $-0,0756$ & 0,0106 & $-0,2534$ & 1,0000 & & & & \\
\hline Governador do PT & $-0,0896$ & $-0,0130$ & $-0,1012$ & 0,0332 & 0,0418 & 0,1052 & 0,0746 & $-0,0915$ & 0,0350 & 0,1944 & $-0,0395$ & $-0,1072$ & $-0,3502$ & 1,0000 & & & \\
\hline Antecedido pelo PSDB & 0,0114 & $-0,0073$ & 0,0708 & $-0,0105$ & 0,0112 & 0,0141 & $-0,0282$ & $-0,0125$ & $-0,0066$ & 0,0001 & $-0,0161$ & $-0,0639$ & 0,1527 & $-0,1148$ & 1,0000 & & \\
\hline Antecedido pelo PT & 0,0237 & 0,0222 & $-0,0374$ & 0,0062 & 0,0239 & 0,0255 & 0,0091 & $-0,0133$ & $-0,0524$ & 0,0151 & $-0,0110$ & 0,0583 & 0,0315 & 0,0076 & $-0,1112$ & 1,0000 & \\
\hline Continuidade & 0,0292 & 0,0125 & 0,0272 & $-0,0232$ & 0,0394 & $-0,0471$ & $-0,0763$ & 0,0743 & $-0,1121$ & $-0,0287$ & 0,1271 & $-0,0168$ & 0,0091 & $-0,0591$ & 0,0001 & 0,1226 & 1,0000 \\
\hline
\end{tabular}

Fonte: Banco de Dados Matrículas e Gastos nos Municípios Brasileiros.

$\mathrm{N}=1993$ 


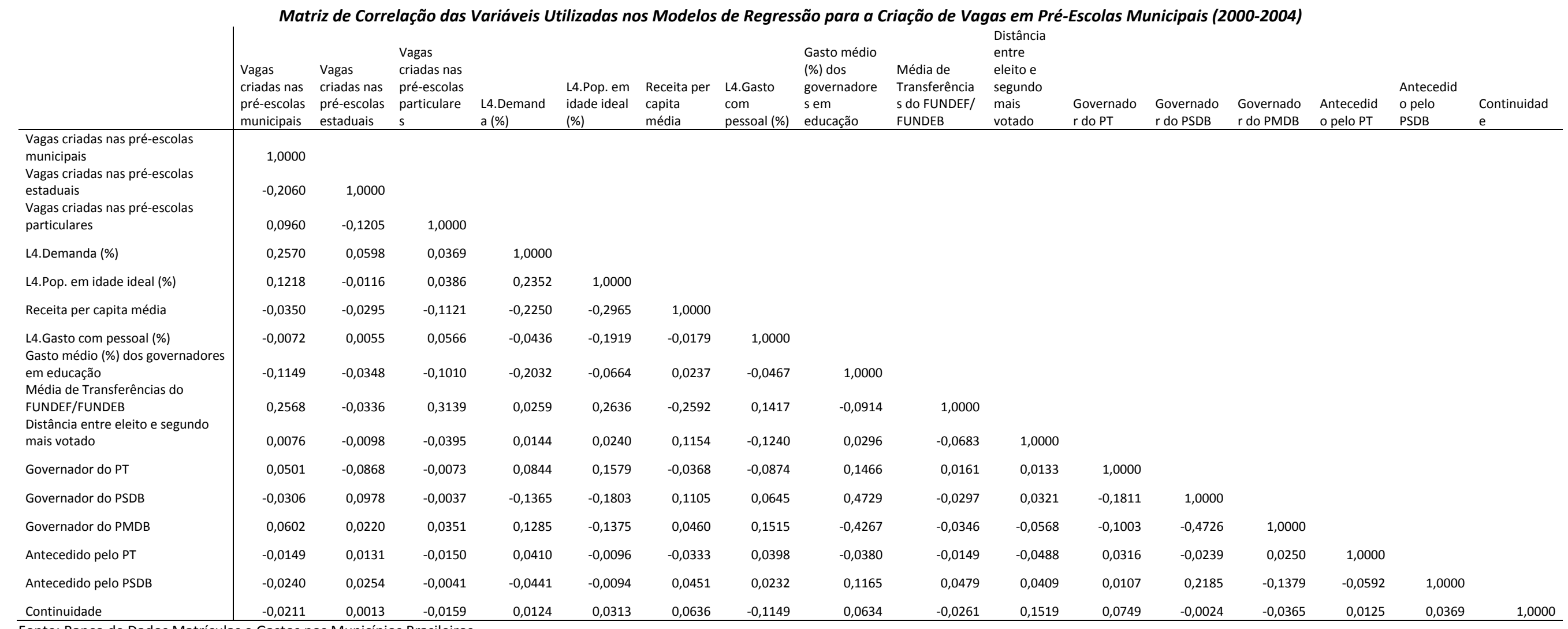

Fonte: Banco de Dados Matrículas e Gastos nos Municípios Brasileiros.

$\mathrm{N}=2067$ 


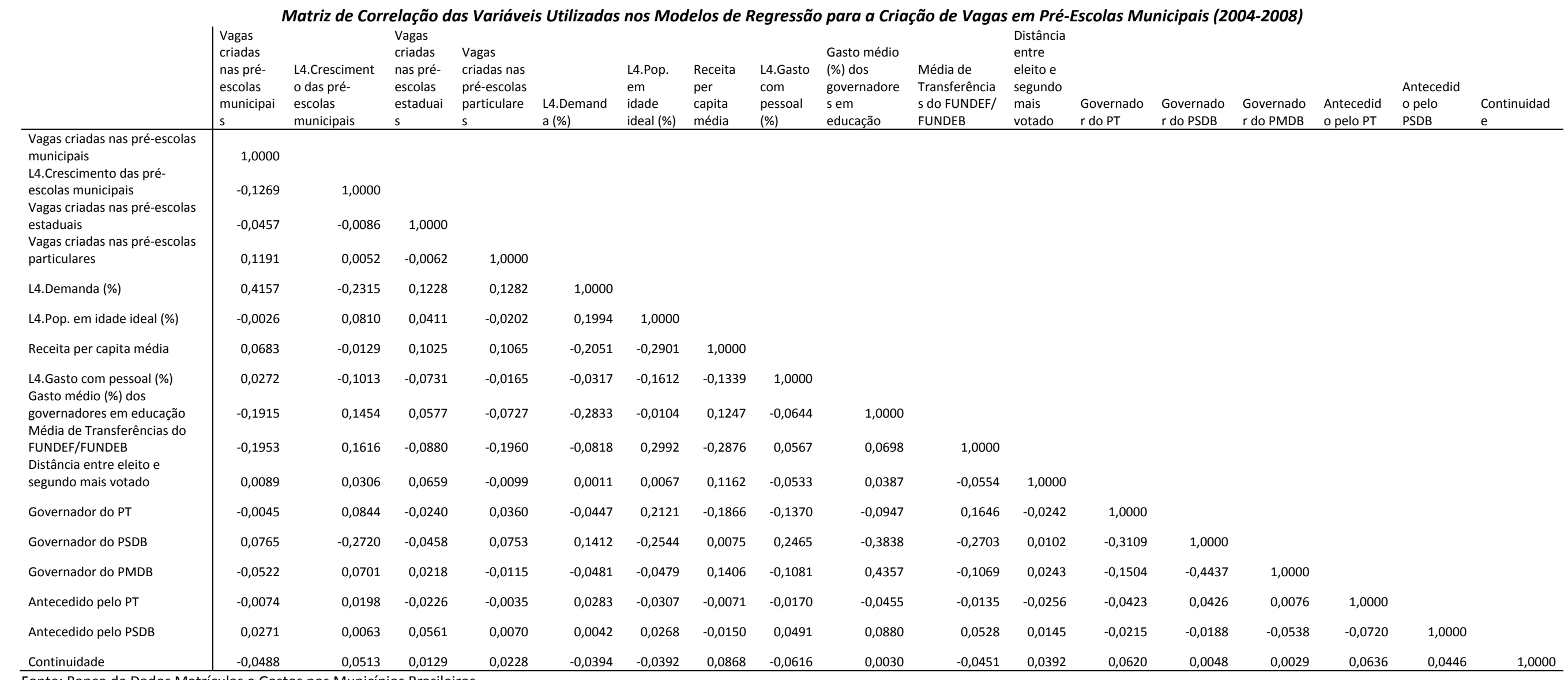

Fonte: Banco de Dados Matrículas e Gastos nos Municípios Brasileiros.

$\mathrm{N}=2067$ 


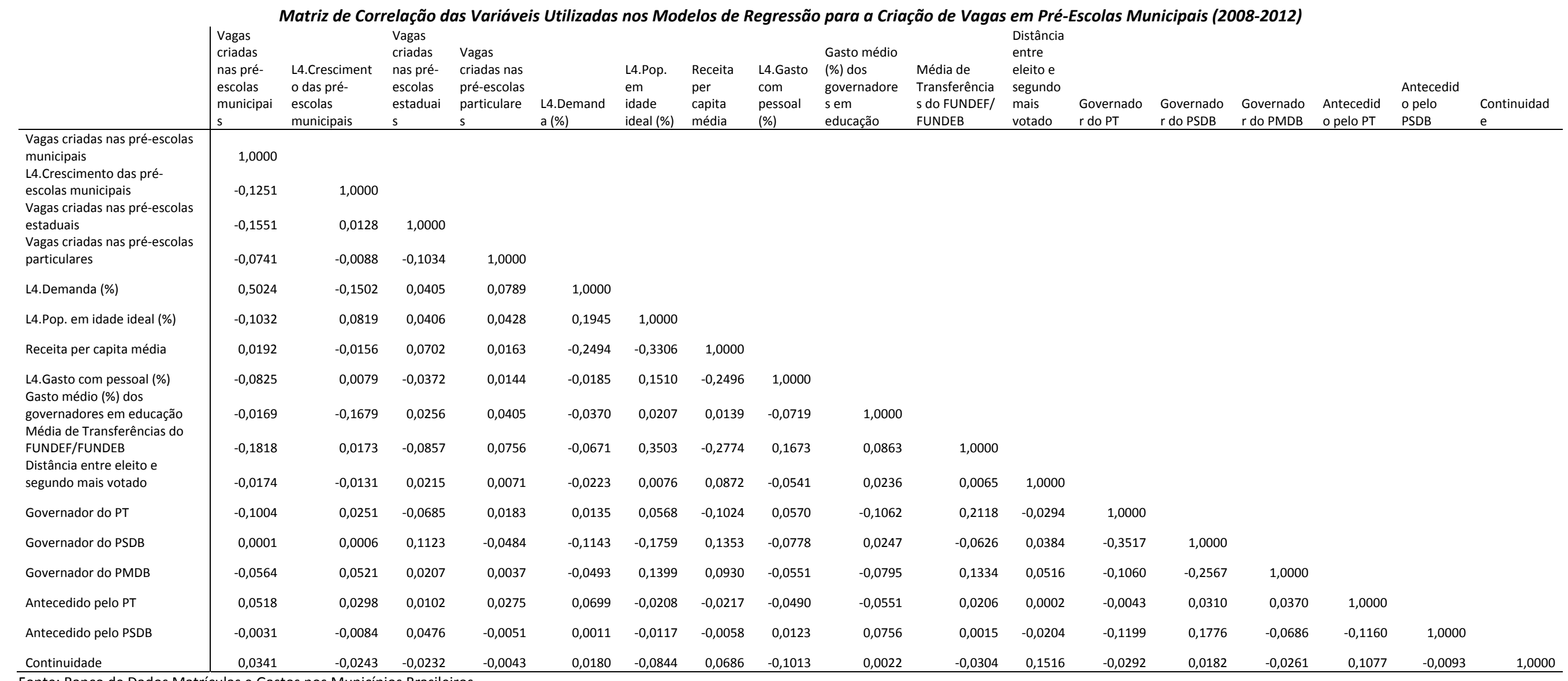

Fonte: Banco de Dados Matrículas e Gastos nos Municípios Brasileiros.

$\mathrm{N}=2067$ 


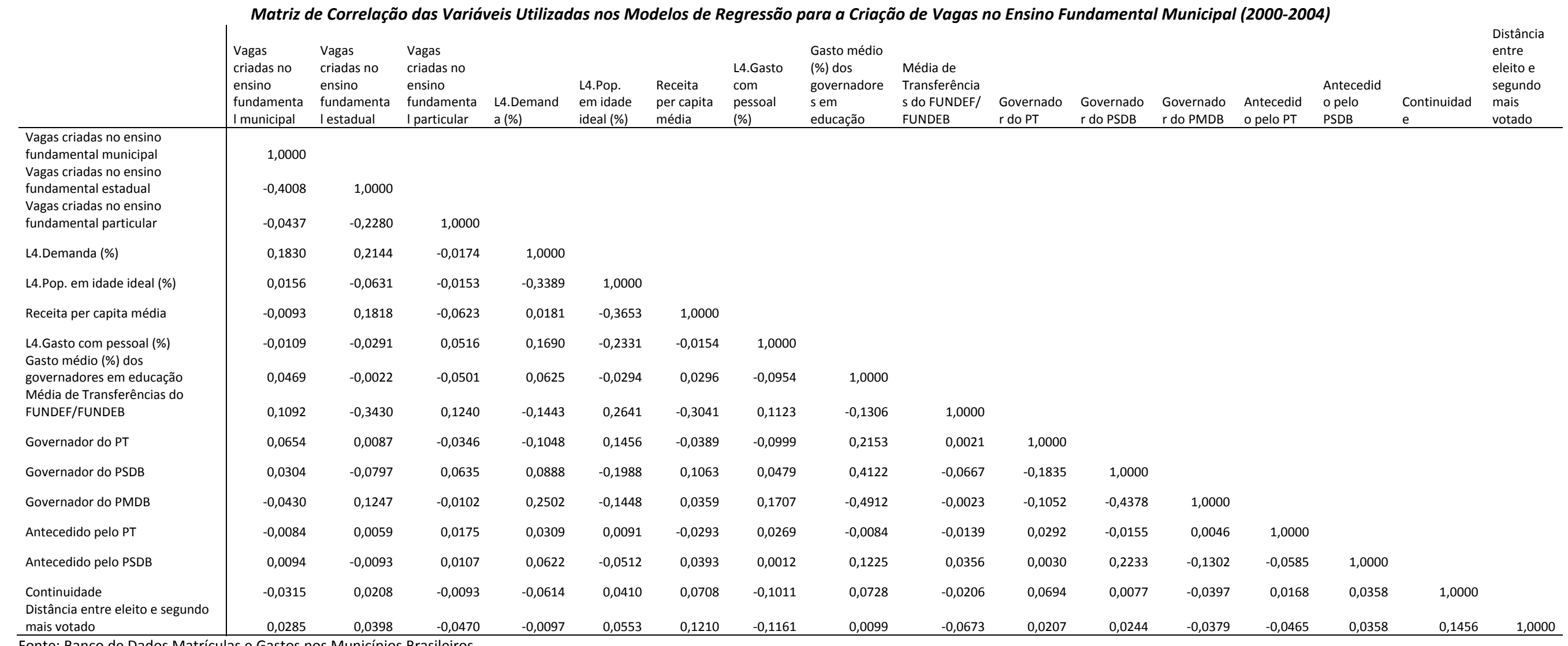

Fonte: Banco de Dados Matrículas e Gastos nos Municípios Brasileiros.

$\mathrm{N}=2514$ 


\begin{tabular}{|c|c|c|c|c|c|c|c|c|c|c|c|c|c|c|c|c|c|}
\hline \multicolumn{17}{|c|}{ Matriz de Correlação das Variáveis Utilizadas nos Modelos de Regressão para a Criação de Vagas no Ensino Fundamental Municipal (2004-2008) } & \multirow[b]{2}{*}{$\begin{array}{l}\text { Distânci } \\
\text { a entre } \\
\text { eleito e } \\
\text { segundo } \\
\text { mais } \\
\text { votado }\end{array}$} \\
\hline & $\begin{array}{l}\text { Vagas } \\
\text { criadas no } \\
\text { ensino } \\
\text { fundamenta } \\
\text { Imunicipal } \\
\end{array}$ & $\begin{array}{l}\text { L4.Cresciment } \\
\text { o do ensino } \\
\text { fundamental } \\
\text { municipal }\end{array}$ & $\begin{array}{l}\text { Vagas } \\
\text { criadas no } \\
\text { ensino } \\
\text { fundamenta } \\
\text { lestadual } \\
\end{array}$ & $\begin{array}{l}\text { Vagas } \\
\text { criadas no } \\
\text { ensino } \\
\text { fundamenta } \\
\text { I particular }\end{array}$ & $\begin{array}{l}\text { L4.Demand } \\
\text { a (\%) }\end{array}$ & $\begin{array}{l}\text { L4.Pop. } \\
\text { em } \\
\text { idade } \\
\text { ideal (\%) }\end{array}$ & $\begin{array}{l}\text { Receita } \\
\text { per } \\
\text { capita } \\
\text { média }\end{array}$ & $\begin{array}{l}\text { L4.Gasto } \\
\text { com } \\
\text { pessoal } \\
(\%)\end{array}$ & $\begin{array}{l}\text { Gasto médio } \\
\text { (\%) dos } \\
\text { governadore } \\
\text { s em } \\
\text { educação }\end{array}$ & $\begin{array}{l}\text { Média de } \\
\text { Transferência } \\
\text { s do FUNDEF/ } \\
\text { FUNDEB }\end{array}$ & $\begin{array}{l}\text { Governado } \\
\text { rdo PT }\end{array}$ & $\begin{array}{l}\text { Governado } \\
\text { rdo PSDB }\end{array}$ & $\begin{array}{l}\text { Governado } \\
\text { rdo PMDB }\end{array}$ & $\begin{array}{l}\text { Antecedid } \\
\text { o pelo PT }\end{array}$ & $\begin{array}{l}\text { Antecedid } \\
\text { o pelo } \\
\text { PSDB }\end{array}$ & $\begin{array}{l}\text { Continuidad } \\
\text { e }\end{array}$ & \\
\hline $\begin{array}{l}\text { Vagas criadas no ensino } \\
\text { fundamental municipal }\end{array}$ & 1,0000 & & & & & & & & & & & & & & & & \\
\hline $\begin{array}{l}\text { L4.Crescimento do ensino } \\
\text { fundamental municipal }\end{array}$ & $-0,0191$ & 1,0000 & & & & & & & & & & & & & & & \\
\hline Vagas criadas no ensino & & & & & & & & & & & & & & & & & \\
\hline fundamental estadual & $-0,1134$ & $-0,0123$ & 1,0000 & & & & & & & & & & & & & & \\
\hline fundamental particular & $-0,0076$ & 0,0263 & $-0,1375$ & 1,0000 & & & & & & & & & & & & & \\
\hline L4.Demanda (\%) & 0,3946 & $-0,1433$ & 0,1079 & 0,0699 & 1,0000 & & & & & & & & & & & & \\
\hline L4.Pop. em idade ideal (\%) & $-0,3386$ & 0,0071 & $-0,1124$ & $-0,0752$ & $-0,3535$ & 1,0000 & & & & & & & & & & & \\
\hline Receita per capita média & 0,2587 & $-0,0460$ & 0,2392 & $-0,0845$ & 0,0139 & $-0,3393$ & 1,0000 & & & & & & & & & & \\
\hline $\begin{array}{l}\text { L4.Gasto com pessoal (\%) } \\
\text { Gasto médio (\%) dos }\end{array}$ & 0,0215 & $-0,0191$ & $-0,0344$ & 0,0493 & 0,0876 & $-0,1527$ & $-0,1372$ & 1,0000 & & & & & & & & & \\
\hline $\begin{array}{l}\text { governadores em educação } \\
\text { Média de Transferências do }\end{array}$ & 0,0913 & 0,0140 & 0,1132 & 0,0513 & 0,1831 & $-0,0455$ & 0,1214 & $-0,0810$ & 1,0000 & & & & & & & & \\
\hline FUNDEF/FUNDEB & $-0,2843$ & 0,1792 & $-0,3056$ & 0,1945 & $-0,1383$ & 0,2981 & $-0,3302$ & 0,0548 & 0,0400 & 1,0000 & & & & & & & \\
\hline Governador do PT & $-0,2847$ & 0,0303 & $-0,0348$ & $-0,0162$ & $-0,2927$ & 0,2981 & $-0,2000$ & $-0,1471$ & $-0,1019$ & 0,1837 & 1,0000 & & & & & & \\
\hline Governador do PSDB & 0,1599 & $-0,0652$ & 0,0382 & 0,0240 & 0,0918 & $-0,2409$ & 0,0385 & 0,2344 & $-0,3509$ & $-0,2983$ & $-0,3296$ & 1,0000 & & & & & \\
\hline Governador do PMDB & 0,1524 & $-0,0613$ & 0,1335 & 0,0682 & 0,2134 & $-0,1205$ & 0,1634 & $-0,0823$ & 0,4513 & $-0,1228$ & $-0,1628$ & $-0,3846$ & 1,0000 & & & & \\
\hline Antecedido pelo PT & 0,0228 & 0,0180 & $-0,0262$ & 0,0131 & 0,0313 & $-0,0234$ & $-0,0077$ & $-0,0319$ & $-0,0360$ & $-0,0056$ & $-0,0358$ & 0,0345 & 0,0065 & 1,0000 & & & \\
\hline Antecedido pelo PSDB & 0,0258 & 0,0238 & 0,0057 & 0,0002 & 0,0169 & $-0,0085$ & $-0,0179$ & 0,0303 & 0,1048 & 0,0482 & $-0,0128$ & $-0,0358$ & $-0,0466$ & $-0,0725$ & 1,0000 & & \\
\hline $\begin{array}{l}\text { Continuidade } \\
\text { Distância entre eleito e }\end{array}$ & $-0,0022$ & 0,0302 & 0,0463 & $-0,0001$ & $-0,0316$ & $-0,0140$ & 0,0790 & $-0,0690$ & 0,0016 & $-0,0451$ & 0,0751 & $-0,0136$ & $-0,0056$ & 0,0658 & 0,0552 & 1,0000 & \\
\hline segundo mais votado & 0,0401 & 0,0049 & 0,0372 & $-0,0271$ & $-0,0359$ & 0,0208 & 0,1192 & $-0,0620$ & 0,0310 & $-0,0545$ & $-0,0111$ & $-0,0022$ & 0,0171 & $-0,0199$ & 0,0057 & 0,0589 & 1,0000 \\
\hline
\end{tabular}

Fonte: Banco de Dados Matrículas e Gastos nos Municípios Brasileiros.

$\mathrm{N}=2514$ 


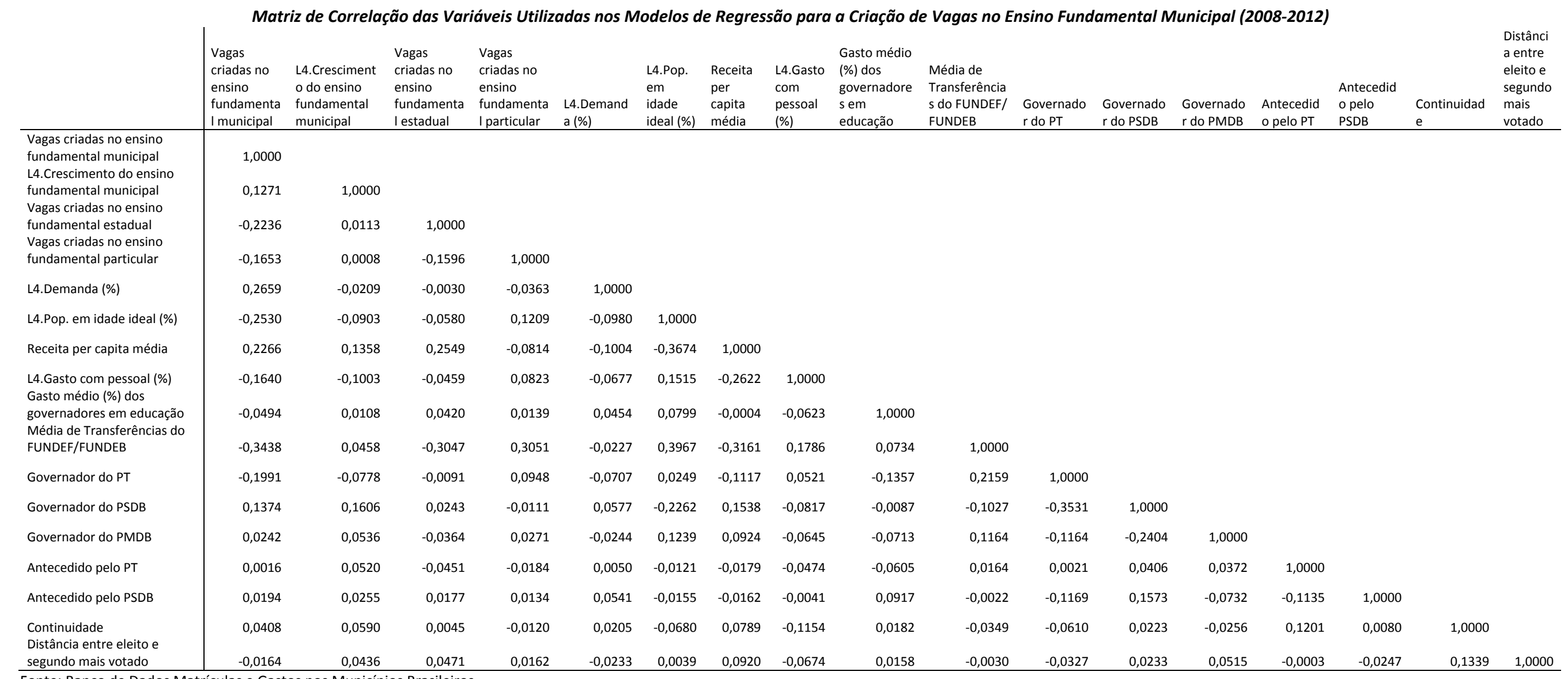

Fonte: Banco de Dados Matrículas e Gastos nos Municípios Brasileiros.

$\mathrm{N}=2514$ 


\begin{tabular}{|c|c|c|c|c|c|c|c|c|c|c|c|c|}
\hline & \multicolumn{12}{|c|}{ Matriz de Correlação das Variáveis Utilizadas nos Modelos de Regressão para a Variação dos Gastos na Educação Municipal (2005-2008) } \\
\hline & $\begin{array}{l}\text { Gasto (\%) } \\
\text { médio em } \\
\text { educação }\end{array}$ & $\begin{array}{l}\text { L4.Gasto (\%) } \\
\text { médio em } \\
\text { educação }\end{array}$ & $\begin{array}{l}\text { Média das } \\
\text { matrículas na } \\
\text { rede } \\
\text { municipal }\end{array}$ & $\begin{array}{l}\text { Gasto médio } \\
\text { (\%) dos } \\
\text { governadores } \\
\text { em educação }\end{array}$ & $\begin{array}{l}\text { Receita per } \\
\text { capita média }\end{array}$ & Continuidade & $\begin{array}{l}\text { Distância } \\
\text { entre eleito e } \\
\text { segundo mais } \\
\text { votado }\end{array}$ & $\begin{array}{l}\text { Governador } \\
\text { do PMDB }\end{array}$ & $\begin{array}{l}\text { Governador } \\
\text { do PSDB }\end{array}$ & $\begin{array}{l}\text { Governador } \\
\text { do PT }\end{array}$ & $\begin{array}{l}\text { Antecedido } \\
\text { pelo PT }\end{array}$ & $\begin{array}{l}\text { Antecedido } \\
\text { pelo PSDB }\end{array}$ \\
\hline Gasto (\%) médio em educação & 1,0000 & & & & & & & & & & & \\
\hline L4.Gasto (\%) médio em educação & 0,2408 & 1,0000 & & & & & & & & & & \\
\hline $\begin{array}{l}\text { municipal } \\
\text { mand }\end{array}$ & 0,5580 & $-0,0164$ & 1,0000 & & & & & & & & & \\
\hline $\begin{array}{l}\text { Gasto medio } \% \text { dos governadores } \\
\text { em educação }\end{array}$ & 0,0033 & 0,0086 & $-0,0020$ & 1,0000 & & & & & & & & \\
\hline Receita per capita média & $-0,4108$ & $-0,0083$ & $-0,3387$ & 0,1396 & 1,0000 & & & & & & & \\
\hline 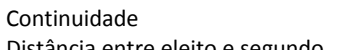 & $-0,0156$ & 0,0525 & $-0,0490$ & $-0,0226$ & 0,0947 & 1,0000 & & & & & & \\
\hline mais votado & $-0,0279$ & 0,0240 & $-0,0686$ & 0,0340 & 0,1194 & 0,0197 & 1,0000 & & & & & \\
\hline Governador do PMDB & $-0,2167$ & $-0,0869$ & $-0,1289$ & 0,4999 & 0,1294 & 0,0035 & 0,0139 & 1,0000 & & & & \\
\hline Governador do PSDB & $-0,2290$ & $-0,0156$ & $-0,2542$ & $-0,4203$ & $-0,0298$ & $-0,0079$ & $-0,0069$ & $-0,4708$ & 1,0000 & & & \\
\hline Governador do PT & 0,3806 & 0,1484 & 0,2157 & $-0,0712$ & $-0,1560$ & 0,0679 & $-0,0049$ & $-0,1424$ & $-0,2966$ & 1,0000 & & \\
\hline Antecedido pelo PT & $-0,0575$ & $-0,0569$ & $-0,0324$ & $-0,0318$ & 0,0050 & 0,0634 & $-0,0353$ & $-0,0009$ & 0,0298 & $-0,0337$ & 1,0000 & \\
\hline Antecedido pelo PSDB & 0,0235 & 0,0140 & 0,0331 & 0,0655 & $-0,0248$ & 0,0394 & 0,0031 & $-0,0437$ & 0,0007 & $-0,0284$ & $-0,0701$ & 1,0000 \\
\hline
\end{tabular}

Fonte: Banco de Dados Matrículas e Gastos nos Municípios Brasileiros.

$\mathrm{N}=1501$ 


\begin{tabular}{|c|c|c|c|c|c|c|c|c|c|c|c|c|}
\hline & \multicolumn{12}{|c|}{ Matriz de Correlação das Variáveis Utilizadas nos Modelos de Regressão para a Variação dos Gastos na Educação Municipal (2009-2012) } \\
\hline & $\begin{array}{l}\text { Gasto (\%) } \\
\text { médio em } \\
\text { educação }\end{array}$ & $\begin{array}{l}\text { L4.Gasto (\%) } \\
\text { médio em } \\
\text { educação }\end{array}$ & $\begin{array}{l}\text { Média das } \\
\text { matrículas na } \\
\text { rede } \\
\text { municipal }\end{array}$ & $\begin{array}{l}\text { Gasto médio } \\
\text { (\%) dos } \\
\text { governadores } \\
\text { em educação }\end{array}$ & $\begin{array}{l}\text { Receita per } \\
\text { capita média }\end{array}$ & Continuidade & $\begin{array}{l}\text { Distância } \\
\text { entre eleito e } \\
\text { segundo mais } \\
\text { votado }\end{array}$ & $\begin{array}{l}\text { Governador } \\
\text { do PMDB }\end{array}$ & $\begin{array}{l}\text { Governador } \\
\text { do PSDB }\end{array}$ & $\begin{array}{l}\text { Governador } \\
\text { do PT }\end{array}$ & $\begin{array}{l}\text { Antecedido } \\
\text { pelo PT }\end{array}$ & $\begin{array}{l}\text { Antecedido } \\
\text { pelo PSDB }\end{array}$ \\
\hline Gasto (\%) médio em educação & 1,0000 & & & & & & & & & & & \\
\hline L4.Gasto (\%) médio em educação & 0,8791 & 1,0000 & & & & & & & & & & \\
\hline municipal & 0,5144 & 0,4989 & 1,0000 & & & & & & & & & \\
\hline em educação & 0,1025 & 0,1020 & 0,0479 & 1,0000 & & & & & & & & \\
\hline Receita per capita média & $-0,4681$ & $-0,4084$ & $-0,3225$ & 0,0299 & 1,0000 & & & & & & & \\
\hline 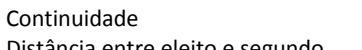 & $-0,0793$ & $-0,0753$ & $-0,0311$ & 0,0107 & 0,0701 & 1,0000 & & & & & & \\
\hline mais votado & $-0,0191$ & $-0,0265$ & $-0,0070$ & 0,0203 & 0,0791 & 0,1594 & 1,0000 & & & & & \\
\hline Governador do PMDB & $-0,0082$ & 0,0070 & 0,1604 & $-0,0726$ & 0,0596 & $-0,0206$ & 0,0325 & 1,0000 & & & & \\
\hline Governador do PSDB & $-0,1761$ & $-0,1753$ & $-0,0863$ & 0,0100 & 0,1252 & 0,0146 & 0,0265 & $-0,2693$ & 1,0000 & & & \\
\hline Governador do PT & 0,2312 & 0,2459 & 0,2024 & $-0,0830$ & $-0,0708$ & $-0,0405$ & $-0,0340$ & $-0,1027$ & $-0,3489$ & 1,0000 & & \\
\hline Antecedido pelo PT & $-0,0153$ & $-0,0363$ & 0,0210 & $-0,0477$ & $-0,0108$ & 0,1219 & $-0,0115$ & 0,0544 & 0,0410 & $-0,0073$ & 1,0000 & \\
\hline Antecedido pelo PSDB & 0,0120 & $-0,0071$ & $-0,0050$ & 0,0430 & 0,0022 & $-0,0222$ & $-0,0085$ & $-0,0666$ & 0,1599 & $-0,1193$ & $-0,1146$ & 1,0000 \\
\hline
\end{tabular}

Fonte: Banco de Dados Matrículas e Gastos nos Municípios Brasileiros.

$\mathrm{N}=1501$ 


\begin{tabular}{|c|c|c|c|c|c|c|c|c|c|c|c|c|c|c|}
\hline & $\begin{array}{l}\text { Matriz de } \\
\text { Gasto (\%) } \\
\text { médio em } \\
\text { educação } \\
\text { infantil }\end{array}$ & $\begin{array}{l}\text { Correlação dc } \\
\text { L4.Gasto (\%) } \\
\text { médio em } \\
\text { educação } \\
\text { infantil }\end{array}$ & Is Variáveis L & $\begin{array}{l}\text { Itilizadas nos } \\
\text { Média de } \\
\text { matrículas na } \\
\text { educação } \\
\text { infantil } \\
\text { municipal }\end{array}$ & $\begin{array}{l}\text { Modelos de } \\
\text { Média de } \\
\text { matrículas na } \\
\text { educação } \\
\text { infantil } \\
\text { estadual }\end{array}$ & $\begin{array}{l}\text { Receita per } \\
\text { capita média }\end{array}$ & $\begin{array}{l}\text { Ira a Variaçã } \\
\text { Gasto médio } \\
\text { (\%) dos } \\
\text { governadores } \\
\text { em educação }\end{array}$ & o dos Gastos & $\begin{array}{l}\text { na Educação } \\
\text { Distância } \\
\text { entre eleito e } \\
\text { segundo mais } \\
\text { votado }\end{array}$ & $\begin{array}{l}\text { Governador } \\
\text { do PMDB }\end{array}$ & $\begin{array}{l}\text { Governador } \\
\text { do PSDB }\end{array}$ & $\begin{array}{l}\text { Governador } \\
\text { do PT }\end{array}$ & $\begin{array}{l}\text { Antecedido } \\
\text { pelo PT }\end{array}$ & $\begin{array}{l}\text { Antecedido } \\
\text { pelo PSDB }\end{array}$ \\
\hline $\begin{array}{l}\text { Gasto (\%) médio em educação } \\
\text { infantil } \\
\text { L4.Gasto (\%) médio em educação } \\
\text { infantil }\end{array}$ & $\begin{array}{l}1,0000 \\
0,7829\end{array}$ & 1,0000 & & & & & & & & & & & & \\
\hline $\begin{array}{l}\text { Pop. em idade ideal (\%) } \\
\text { Média de matrículas na educação } \\
\text { infantil municipal } \\
\text { Média de matrículas na educação } \\
\text { infantil estadual }\end{array}$ & $\begin{array}{r}0,1267 \\
-0,0261\end{array}$ & $\begin{array}{l}-0,2921 \\
0,1804 \\
-0,0382\end{array}$ & $\begin{array}{l}1,0000 \\
0,2650 \\
0,0492\end{array}$ & $\begin{array}{l}1,0000 \\
0,0752\end{array}$ & 1,0000 & & & & & & & & & \\
\hline $\begin{array}{l}\text { Receita per capita média } \\
\text { Gasto médio (\%) dos governadores } \\
\text { em educação }\end{array}$ & 0,1235 & 0,1061 & $\begin{array}{l}-0,1876 \\
-0,0028\end{array}$ & $-0,2354$ & $\begin{array}{l}-0,0690 \\
-0,0050\end{array}$ & $\begin{array}{l}1,0000 \\
0,0024\end{array}$ & 1,0000 & & & & & & & \\
\hline $\begin{array}{l}\text { Continuidade } \\
\text { Distância entre eleito e segundo } \\
\text { mais votado }\end{array}$ & 0,0928 & 0,0726 & $\begin{array}{l}-0,0927 \\
-0,0273\end{array}$ & $\begin{array}{l}-0,0415 \\
-0,0270\end{array}$ & $\begin{array}{l}-0,0018 \\
-0,0165\end{array}$ & $\begin{array}{l}0,0377 \\
0,0604\end{array}$ & $\begin{array}{l}0,0095 \\
0,0505\end{array}$ & $\begin{array}{l}1,0000 \\
0,1566\end{array}$ & 1,0000 & & & & & \\
\hline Governador do PMDB & $-0,0481$ & $-0,0694$ & 0,1931 & 0,1678 & $-0,0372$ & 0,0405 & $-0,1129$ & $-0,0255$ & 0,0099 & 1,0000 & & & & \\
\hline Governador do PSDB & 0,2746 & 0,3665 & $-0,1402$ & $-0,0260$ & $-0,0944$ & 0,0555 & 0,1456 & 0,0267 & 0,0833 & $-0,2620$ & 1,0000 & & & \\
\hline Governador do PT & $-0,1356$ & $-0,1629$ & $-0,0426$ & 0,0284 & 0,1310 & 0,0232 & $-0,1379$ & $-0,0399$ & $-0,0553$ & $-0,1160$ & $-0,3908$ & 1,0000 & & \\
\hline Antecedido pelo PT & 0,0301 & 0,0101 & 0,0052 & 0,0094 & $-0,0113$ & $-0,0162$ & $-0,0138$ & 0,0838 & $-0,0094$ & 0,0722 & 0,0121 & $-0,0009$ & 1,0000 & \\
\hline Antecedido pelo PSDB & 0,0032 & 0,0417 & 0,0056 & 0,0073 & $-0,0067$ & $-0,0113$ & 0,0202 & 0,0095 & $-0,0029$ & $-0,0730$ & 0,1986 & $-0,1361$ & $-0,1125$ & 1,0000 \\
\hline
\end{tabular}

Fonte: Banco de Dados Matrículas e Gastos nos Municípios Brasileiros.

$\mathrm{N}=2785$ 


\begin{tabular}{|c|c|c|c|c|c|c|c|c|c|c|c|c|c|c|}
\hline & $\begin{array}{l}\text { Matriz de C } \\
\text { Gasto (\%) } \\
\text { médio em } \\
\text { ensino } \\
\text { fundamental } \\
\end{array}$ & $\begin{array}{l}\text { orrelação das } \\
\text { L4.Gasto (\%) } \\
\text { médio em } \\
\text { ensino } \\
\text { fundamental }\end{array}$ & Variáveis Ut & $\begin{array}{l}\text { ilizadas nos I } \\
\text { Média de } \\
\text { matrículas no } \\
\text { ensino } \\
\text { fundamental } \\
\text { municipal }\end{array}$ & $\begin{array}{l}\text { Modelos de } R \\
\text { Média de } \\
\text { matrículas no } \\
\text { ensino } \\
\text { fundamental } \\
\text { estadual } \\
\end{array}$ & $\begin{array}{l}\text { Receita per } \\
\text { capita média }\end{array}$ & $\begin{array}{l}\text { a a Variação } \\
\text { Gasto médio } \\
\text { (\%) dos } \\
\text { governadores } \\
\text { em educação }\end{array}$ & dos Gastos n & $\begin{array}{l}\text { o Ensino Fun } \\
\text { Distância } \\
\text { entre eleito e } \\
\text { segundo mais } \\
\text { votado }\end{array}$ & $\begin{array}{l}\text { Governador } \\
\text { do PMDB }\end{array}$ & $\begin{array}{l}\text { Governador } \\
\text { do PSDB }\end{array}$ & $\begin{array}{l}\text { Governador } \\
\text { do PT }\end{array}$ & $\begin{array}{l}\text { Antecedido } \\
\text { pelo PT }\end{array}$ & $\begin{array}{l}\text { Antecedido } \\
\text { pelo PSDB }\end{array}$ \\
\hline $\begin{array}{l}\text { Gasto (\%) médio em ensino } \\
\text { fundamental } \\
\text { L4.Gasto (\%) médio em ensino } \\
\text { fundamental }\end{array}$ & $\begin{array}{l}1,0000 \\
0,5435\end{array}$ & 1,0000 & & & & & & & & & & & & \\
\hline $\begin{array}{l}\text { Pop. em idade ideal (\%) } \\
\text { Média de matrículas no ensino } \\
\text { fundamental municipal } \\
\text { Média de matrículas no ensino } \\
\text { fundamental estadual }\end{array}$ & $\begin{array}{l}0,2561 \\
0,0907\end{array}$ & $\begin{array}{r}0,2075 \\
0,0461 \\
-0,1453\end{array}$ & $\begin{array}{l}1,0000 \\
0,4191 \\
0,0169\end{array}$ & $\begin{array}{l}1,0000 \\
0,1299\end{array}$ & 1,0000 & & & & & & & & & \\
\hline $\begin{array}{l}\text { Receita per capita média } \\
\text { Gasto médio (\%) dos governadores } \\
\text { em educação }\end{array}$ & $\begin{array}{l}-0,1548 \\
-0,0131\end{array}$ & $\begin{array}{l}-0,1176 \\
-0,0143\end{array}$ & $\begin{array}{r}-0,3342 \\
0,0265\end{array}$ & $\begin{array}{l}-0,3314 \\
-0,2558\end{array}$ & $\begin{array}{r}-0,2953 \\
0,1896\end{array}$ & $\begin{array}{r}1,0000 \\
-0,0204\end{array}$ & 1,0000 & & & & & & & \\
\hline $\begin{array}{l}\text { Continuidade } \\
\text { Distância entre eleito e segundo } \\
\text { mais votado }\end{array}$ & $\begin{array}{r}-0,0351 \\
0,0091\end{array}$ & $-0,0270$ & $\begin{array}{l}-0,0642 \\
-0,0086\end{array}$ & $\begin{array}{l}-0,0371 \\
-0,0055\end{array}$ & $\begin{array}{l}-0,0248 \\
-0,0525\end{array}$ & 0,0747 & $\begin{array}{l}0,0285 \\
0,0279\end{array}$ & 1,0000 & 1,0000 & & & & & \\
\hline Governador do PMDB & $-0,0024$ & 0,0060 & 0,0979 & 0,1034 & 0,0664 & 0,0999 & 0,0972 & $-0,0237$ & 0,0426 & 1,0000 & & & & \\
\hline Governador do PSDB & $-0,2024$ & $-0,2027$ & $-0,2072$ & $-0,1480$ & 0,0922 & 0,1426 & 0,0725 & 0,0122 & 0,0224 & $-0,2412$ & 1,0000 & & & \\
\hline Governador do PT & 0,1213 & 0,0929 & 0,0595 & 0,2380 & $-0,1226$ & $-0,1058$ & $-0,3709$ & $-0,0643$ & $-0,0407$ & $-0,1173$ & $-0,3516$ & 1,0000 & & \\
\hline Antecedido pelo PT & $-0,0281$ & $-0,0273$ & $-0,0173$ & 0,0075 & 0,0922 & $-0,0153$ & 0,0959 & 0,1290 & 0,0036 & 0,0375 & 0,0452 & 0,0036 & 1,0000 & \\
\hline Antecedido pelo PSDB & $-0,0214$ & $-0,0080$ & $-0,0208$ & 0,0025 & $-0,0472$ & $-0,0198$ & $-0,0366$ & 0,0065 & $-0,0212$ & $-0,0809$ & 0,1507 & $-0,1122$ & $-0,1164$ & 1,0000 \\
\hline
\end{tabular}

Fntecedido pelo PSB

$\mathrm{N}=2297$ 
APÊNDICE C: GRÁFICOS DE EFEITO MARGINAL DA DEMANDA SOBRE A CRIAÇÃO DE VAGAS EM CRECHES, PRÉ-ESCOLAS E ENSINO FUNDAMENTAL NO GOVERNO DOS PREFEITOS DOS PARTIDOS DESTACADOS
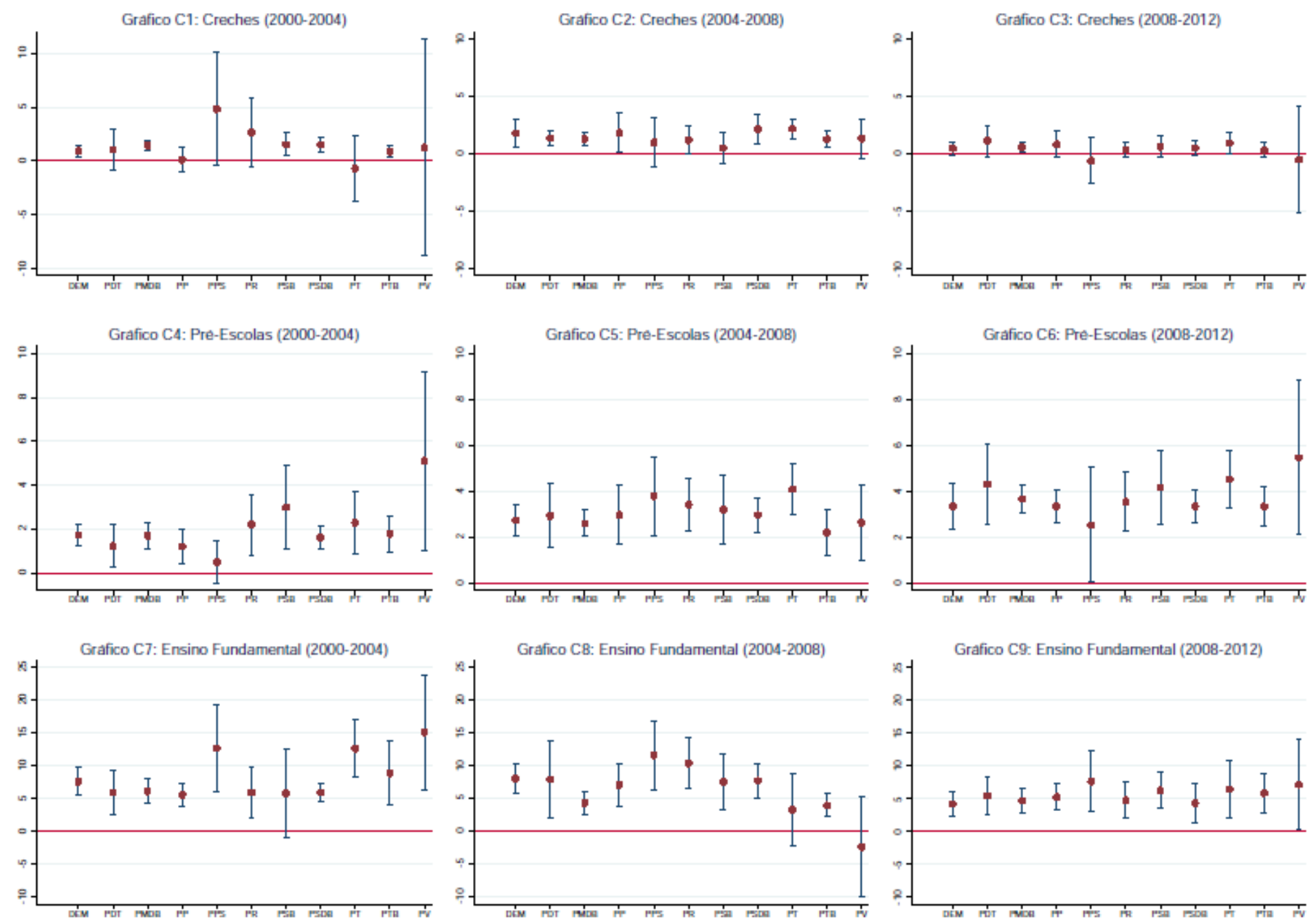

Fonte: Banco de Dados Matrículas e Gastos nos Municípios Brasileiros. 
APÊNDICE D: GRÁFICOS DE EFEITO MARGINAL DOS PARTIDOS DOS PREFEITOS SOBRE A CRIAÇÃO DE VAGAS EM CRECHES, PRÉ-ESCOLAS E ENSINO FUNDAMENTAL QUANDO A DEMANDA POR VAGAS VARIA

Gráfico D1: Efeito marginal dos partidos dos prefeitos sobre a criação de vagas em creches quando a demanda por vagas varia (2000 - 2004)
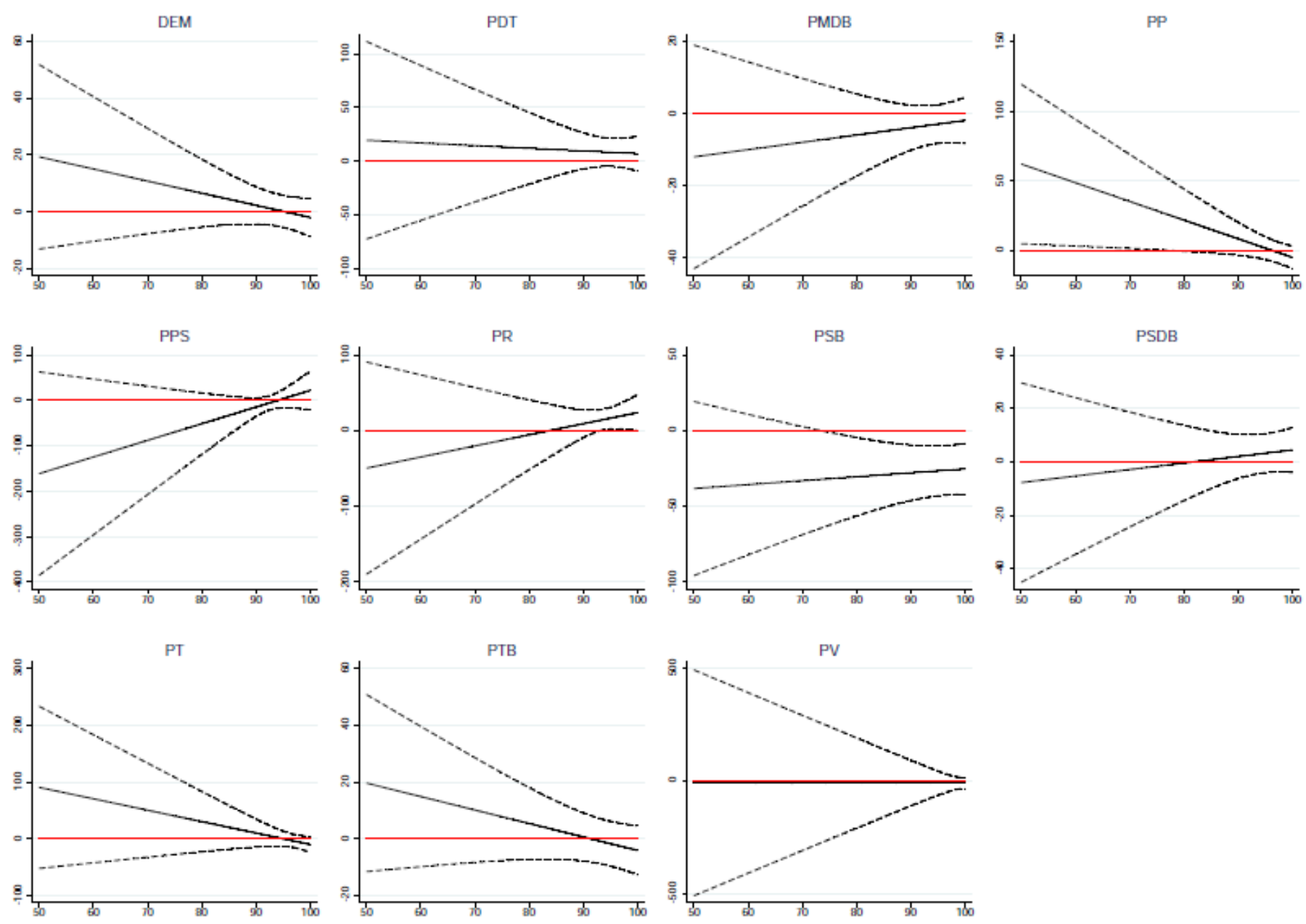

Fonte: Banco de Dados Matrículas e Gastos nos Municípios Brasileiros. 
Gráfico D2: Efeito marginal dos partidos dos prefeitos sobre a criação de vagas em creches quando a demanda por vagas varia (2004 - 2008)
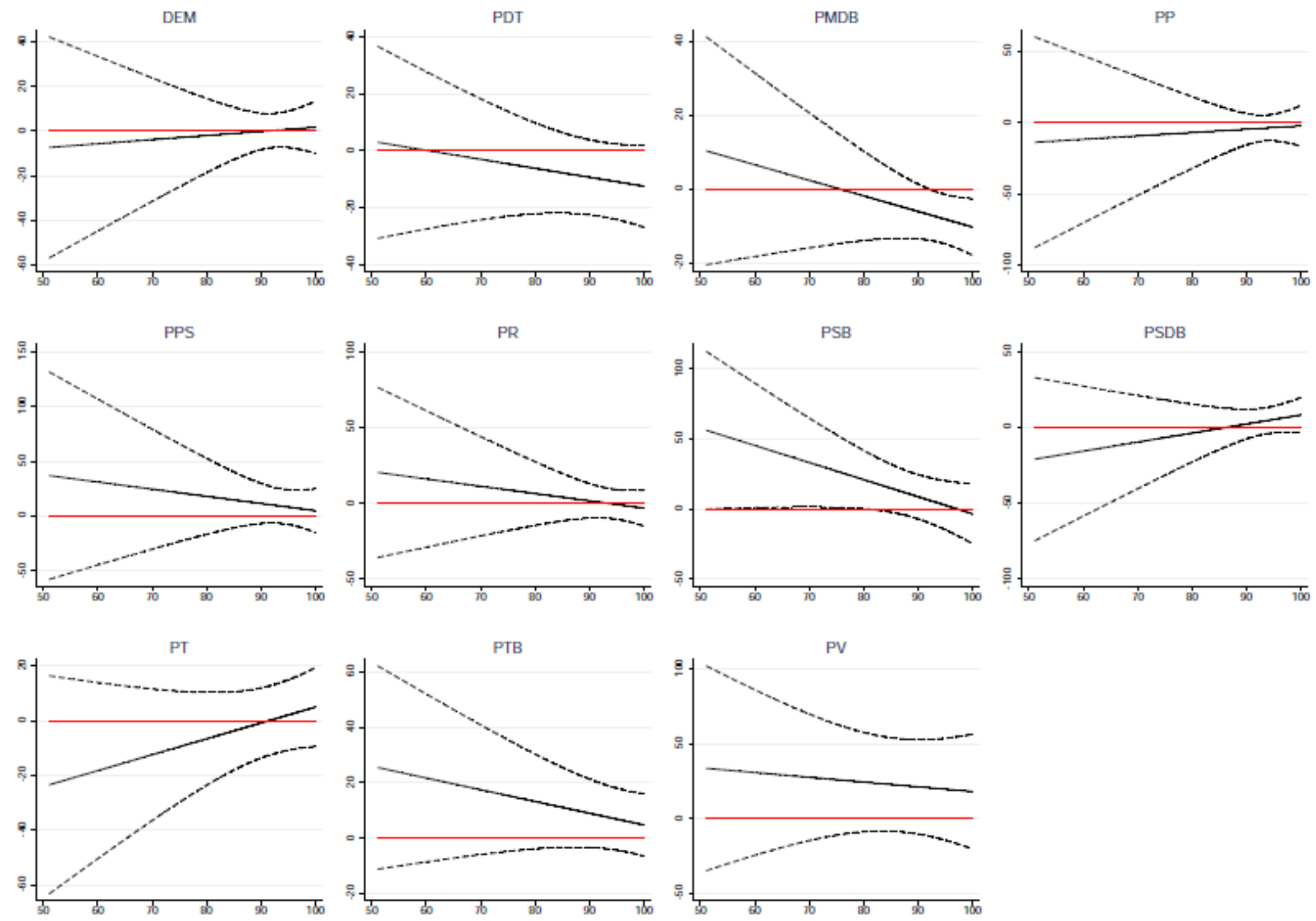

Fonte: Banco de Dados Matrículas e Gastos nos Municípios Brasileiros. 
Gráfico D3: Efeito marginal dos partidos dos prefeitos sobre a criação de vagas em creches quando a demanda por vagas varia (2008 - 2012)
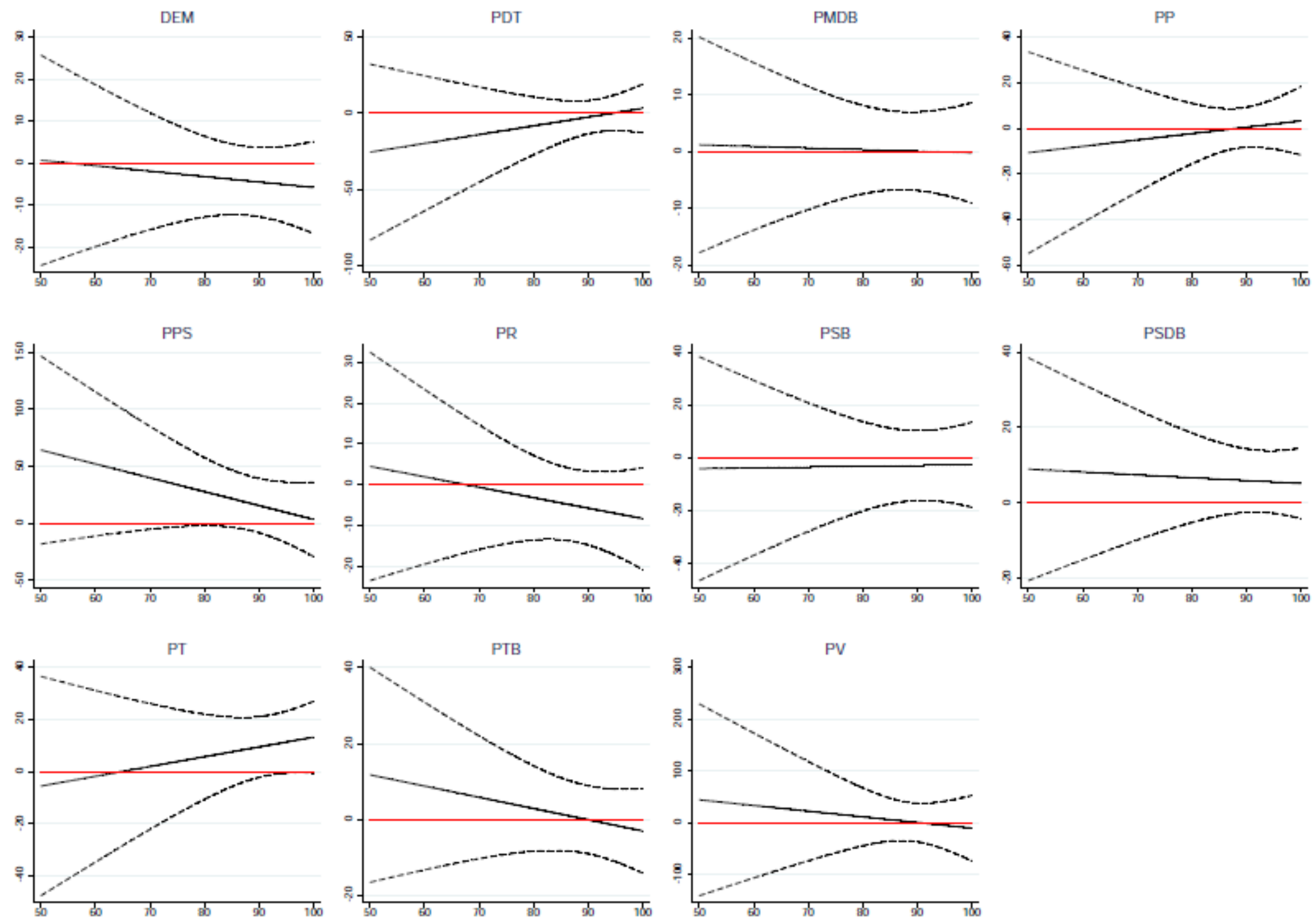

Fonte: Banco de Dados Matrículas e Gastos nos Municípios Brasileiros. 
Gráfico D4: Efeito marginal dos partidos dos prefeitos sobre a criação de vagas em pré escolas quando a demanda por vagas varia (2000 - 2004)
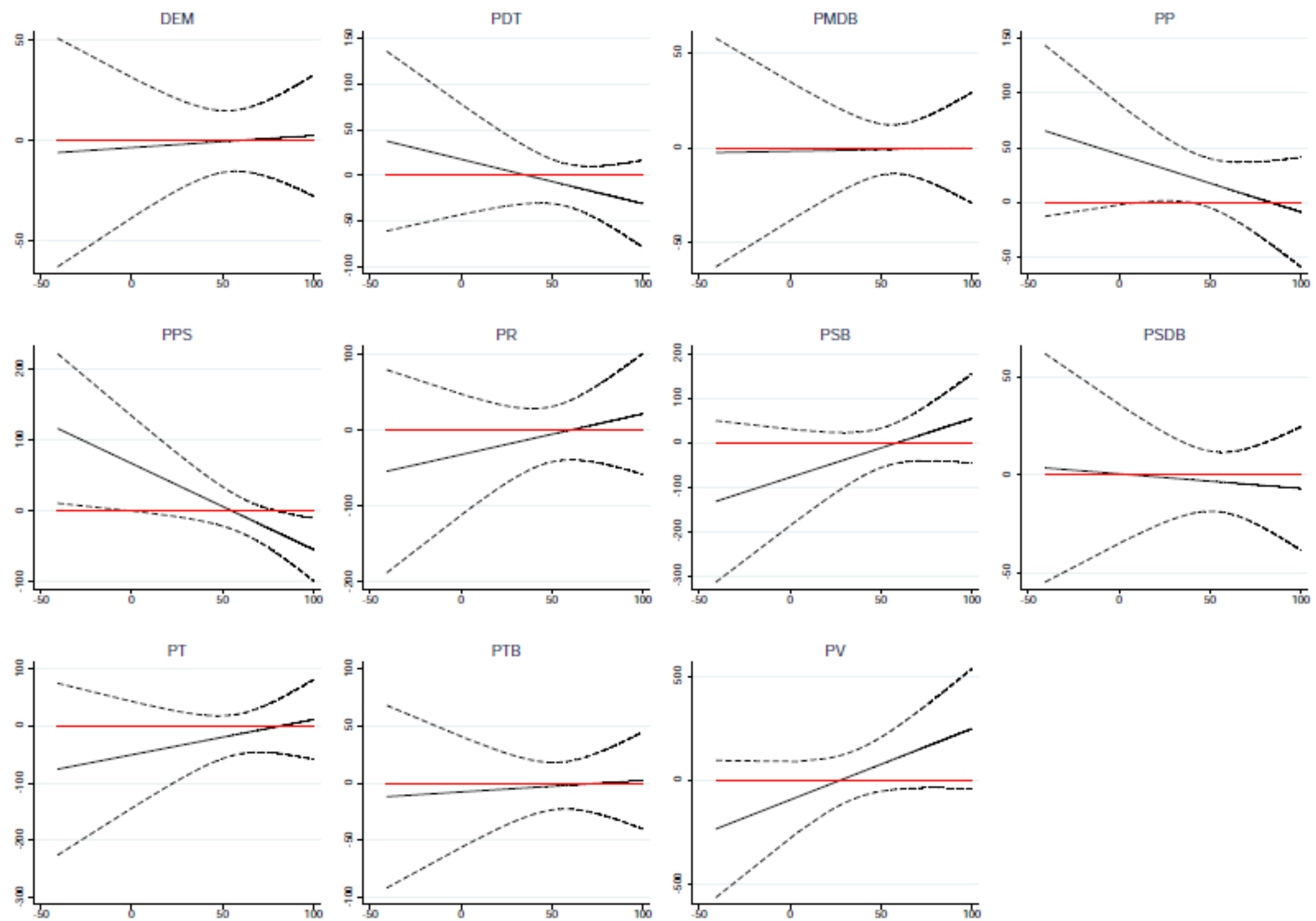

Fonte: Banco de Dados Matrículas e Gastos nos Municípios Brasileiros. 
Gráfico D5: Efeito marginal dos partidos dos prefeitos sobre a criação de vagas em pré escolas quando a demanda por vagas varia (2004 - 2008)

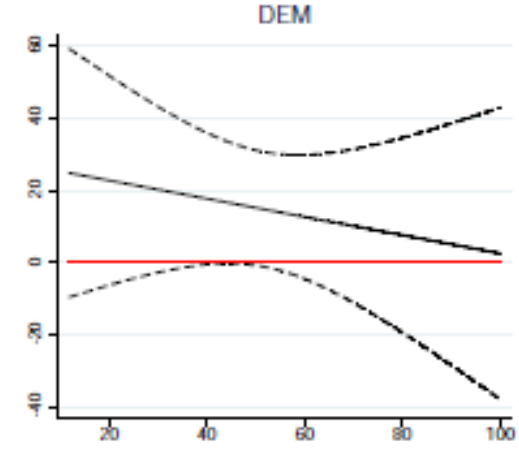

PPS

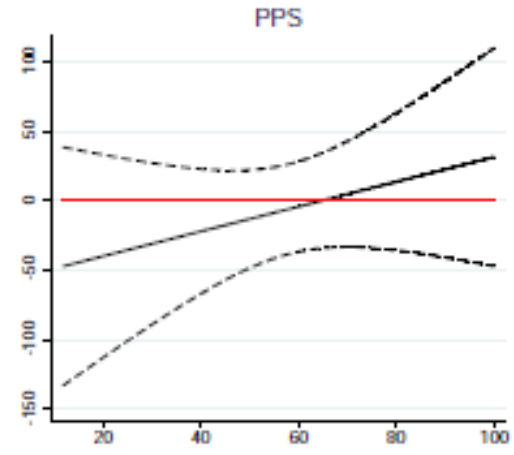

PT

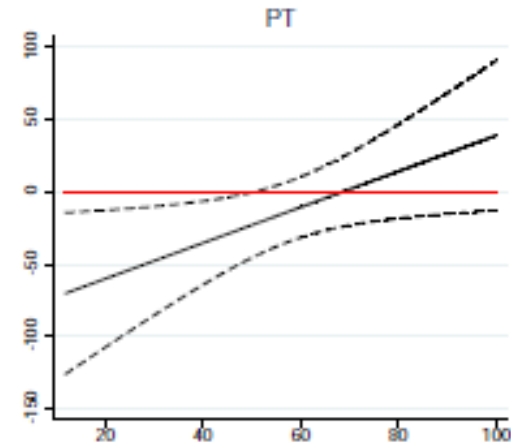

PDT

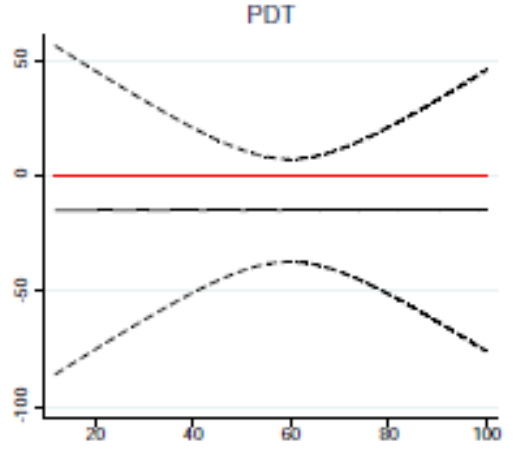

PR
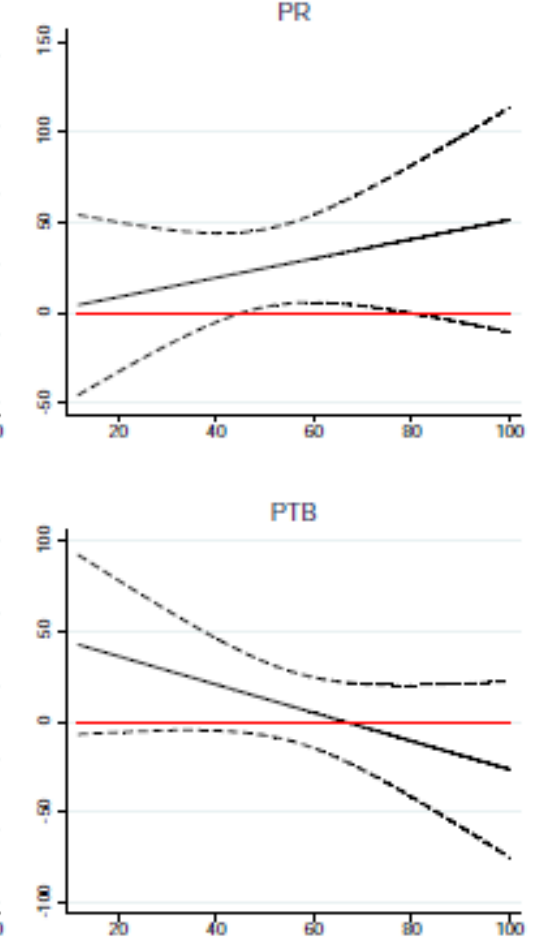

PMDB

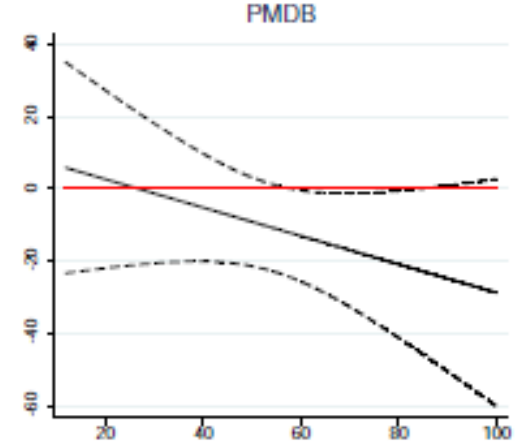

PSB

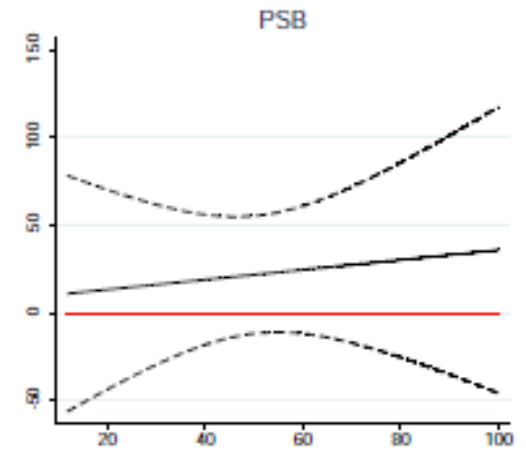

PV

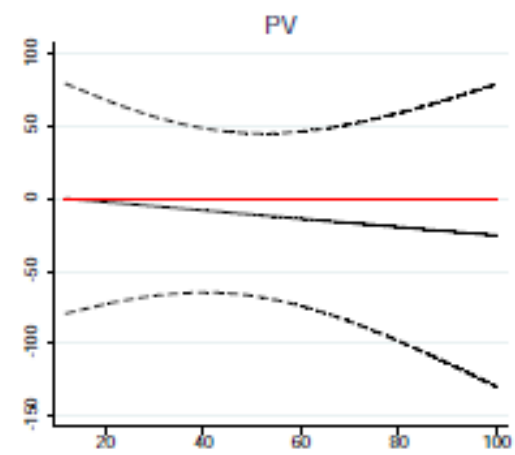

PP

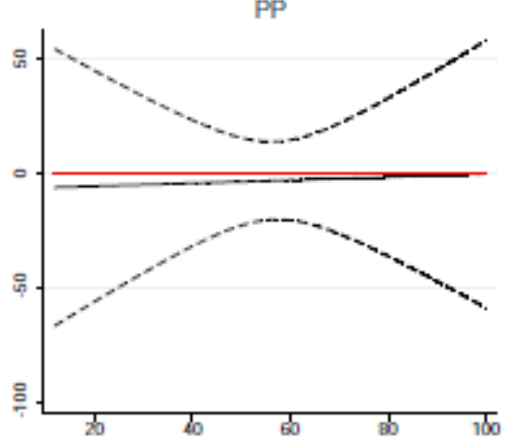

PSDB

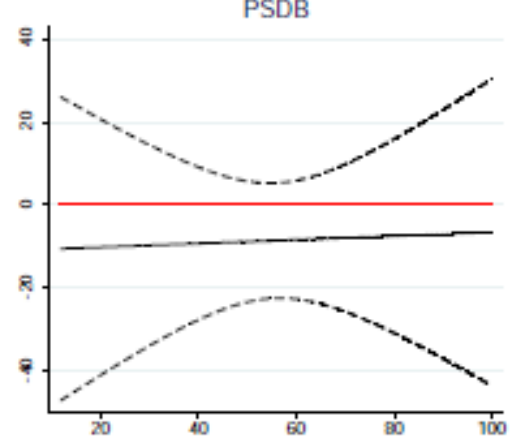

Fonte: Banco de Dados Matrículas e Gastos nos Municípios Brasileiros. 
Gráfico D6: Efeito marginal dos partidos dos prefeitos sobre a criação de vagas em pré escolas quando a demanda por vagas varia (2008 - 2012)
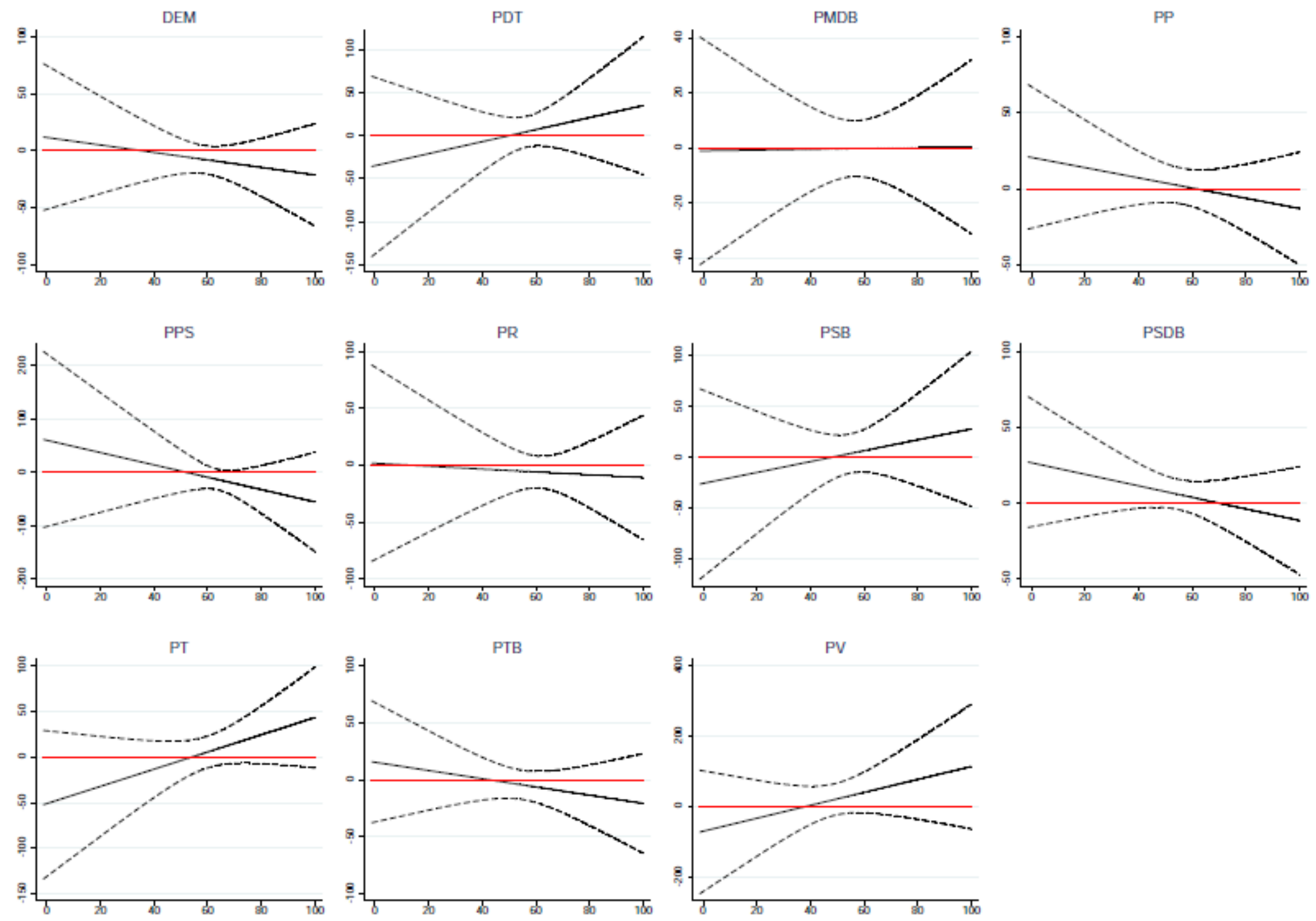

Fonte: Banco de Dados Matrículas e Gastos nos Municípios Brasileiros. 
Gráfico D7: Efeito marginal dos partidos dos prefeitos sobre a criação de vagas em ensino fundamental quando a demanda por vagas varia (2000 - 2004)
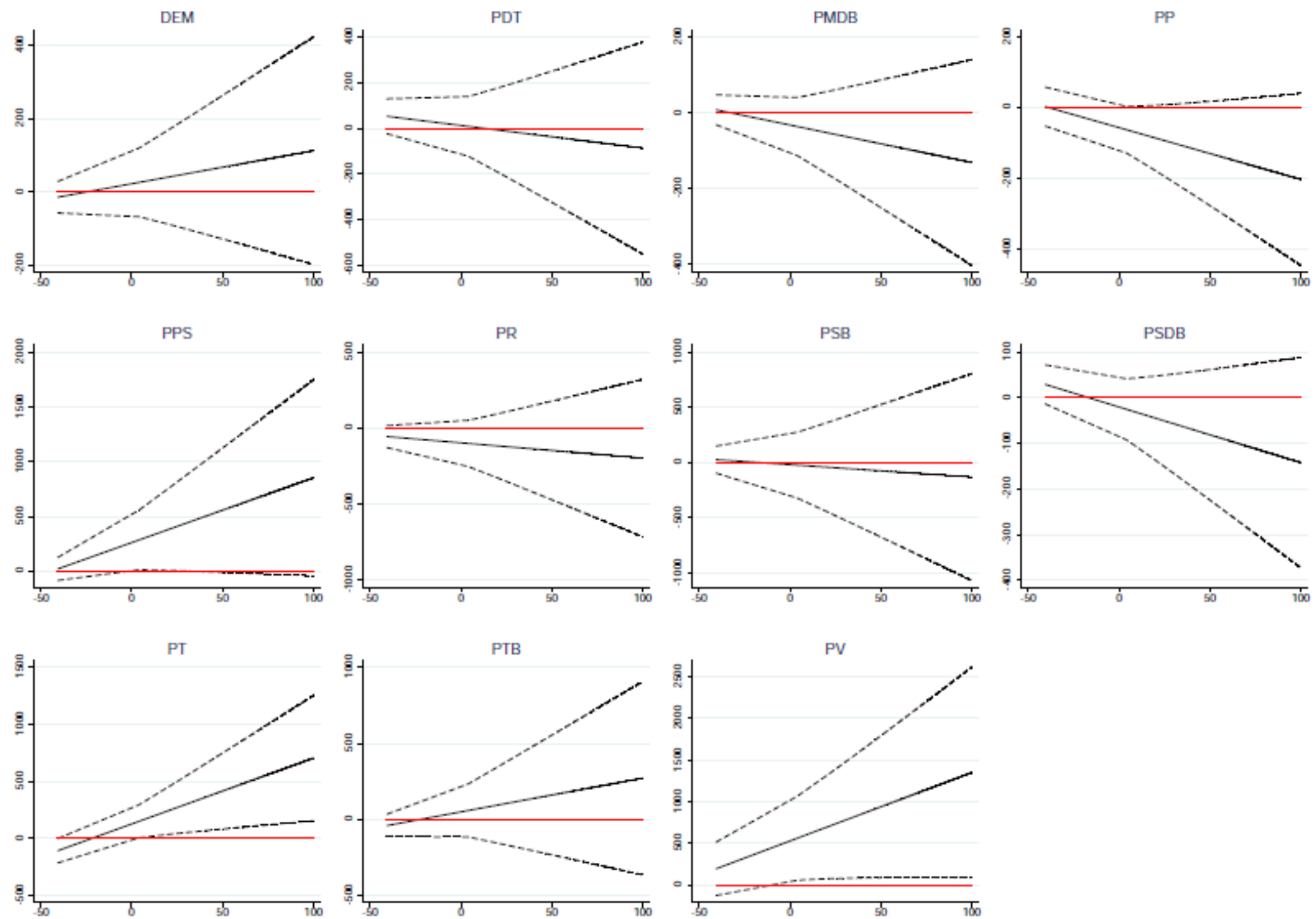

Fonte: Banco de Dados Matrículas e Gastos nos Municípios Brasileiros. 
Gráfico D8: Efeito marginal dos partidos dos prefeitos sobre a criação de vagas em ensino fundamental quando a demanda por vagas varia (2004 - 2008)
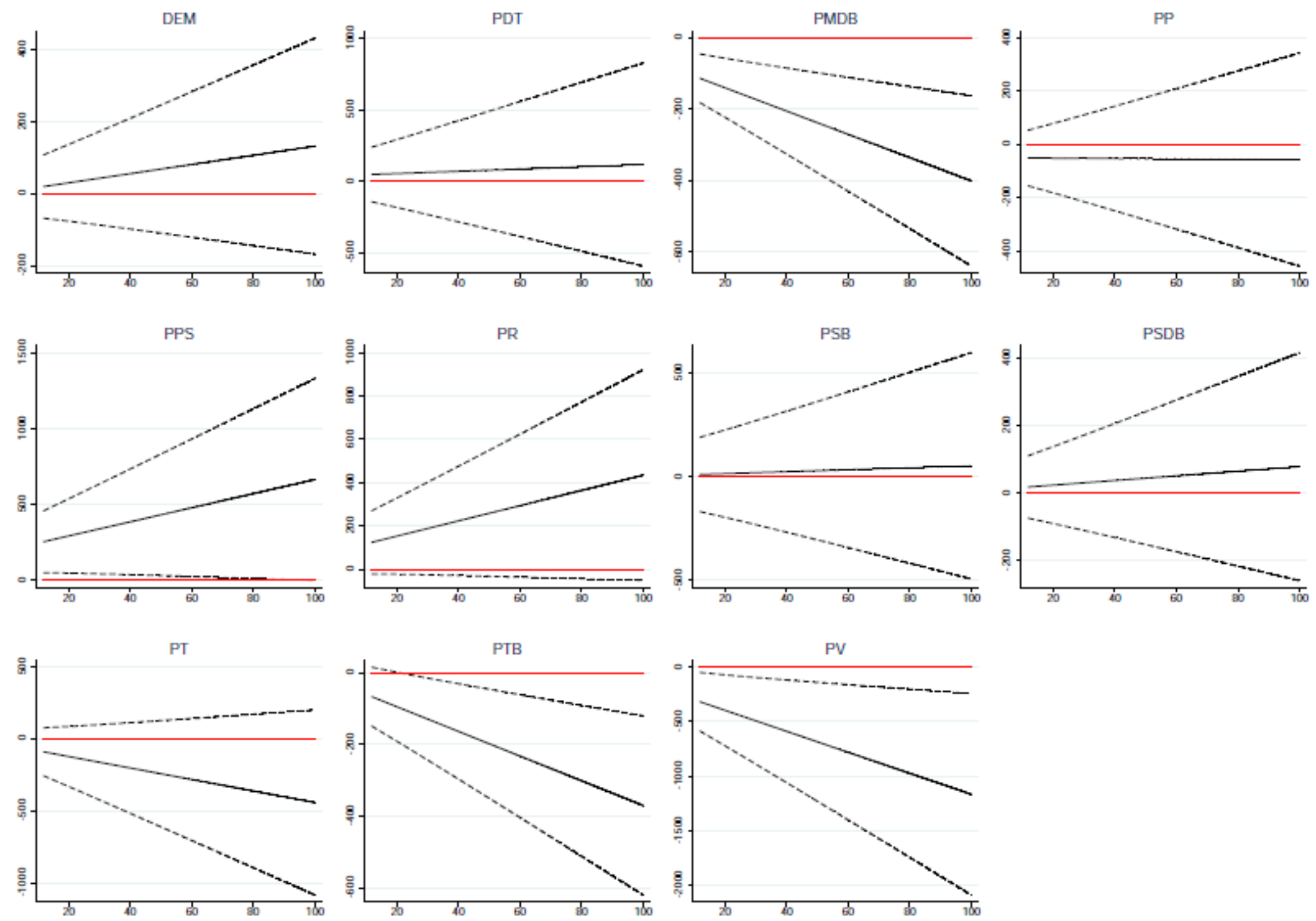

Fonte: Banco de Dados Matrículas e Gastos nos Municípios Brasileiros. 
Gráfico D9: Efeito marginal dos partidos dos prefeitos sobre a criação de vagas em ensino fundamental quando a demanda por vagas varia (2008 - 2012)
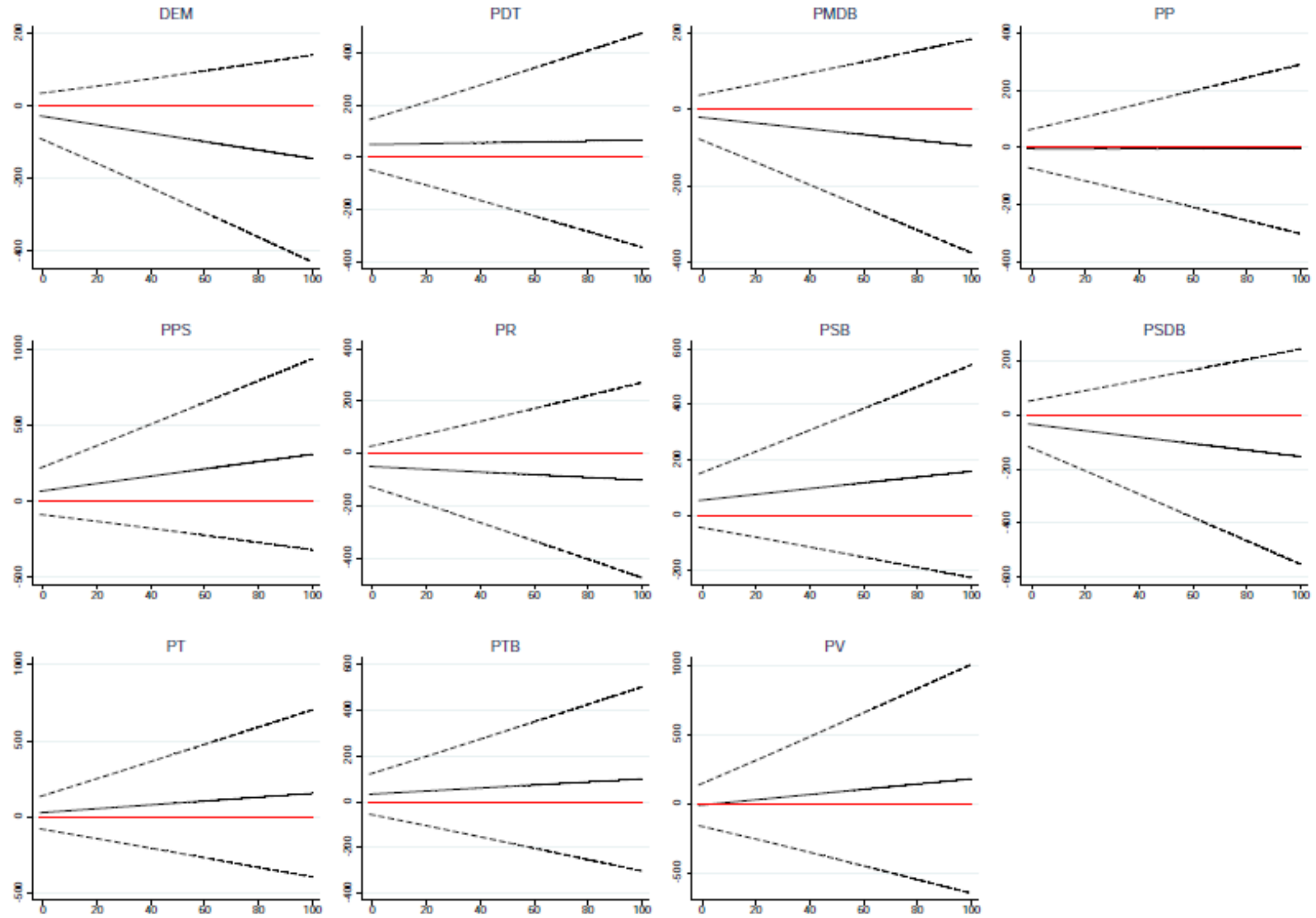

Fonte: Banco de Dados Matrículas e Gastos nos Municípios Brasileiros. 
APÊNDICE E: ESTADOS GOVERNADOS PELO PMDB, PSDB E PT (1999-2014)

Figura E10: Estados Governados pelo PMDB

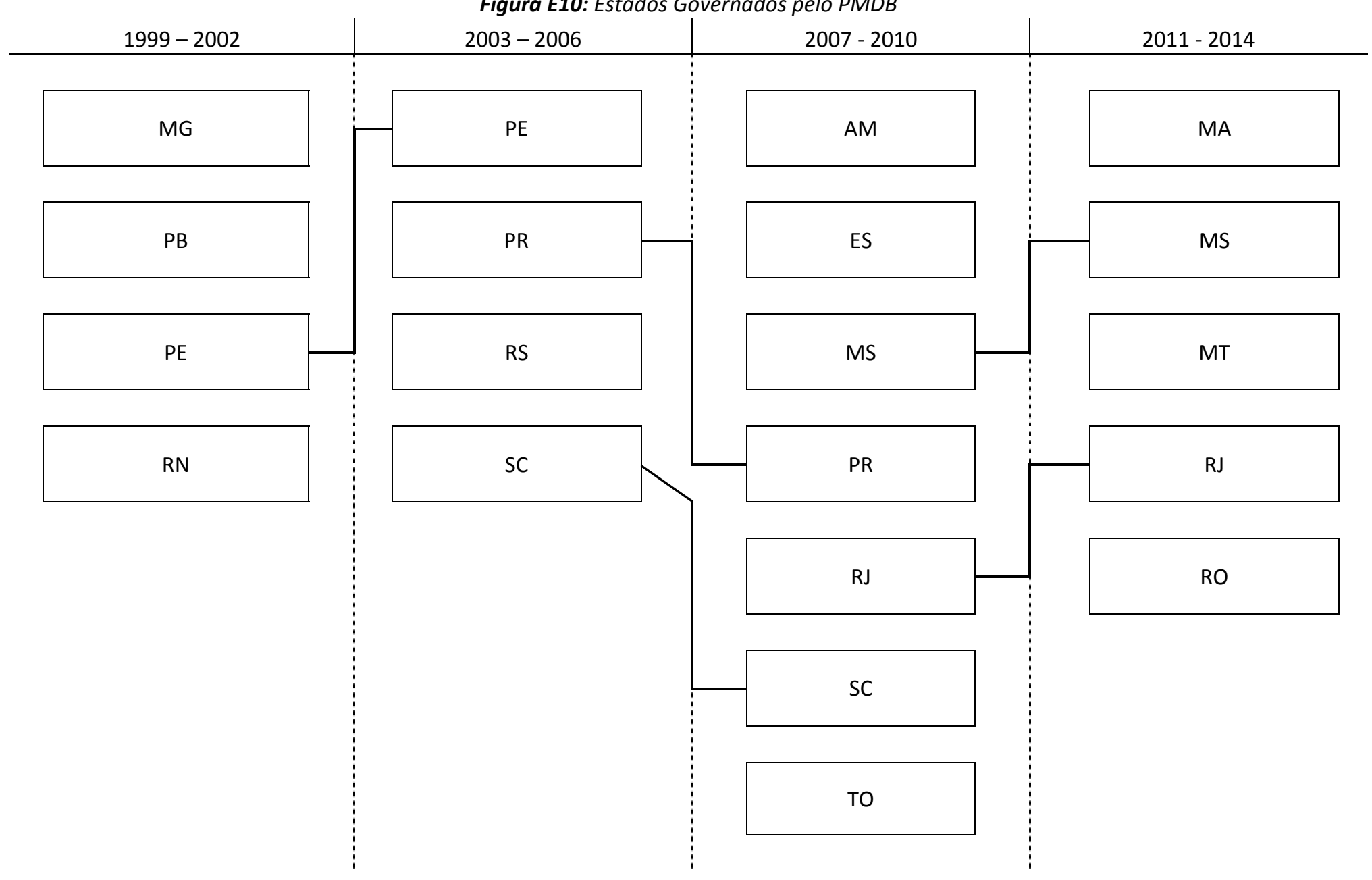

Fonte: www.tse.jus.br. 


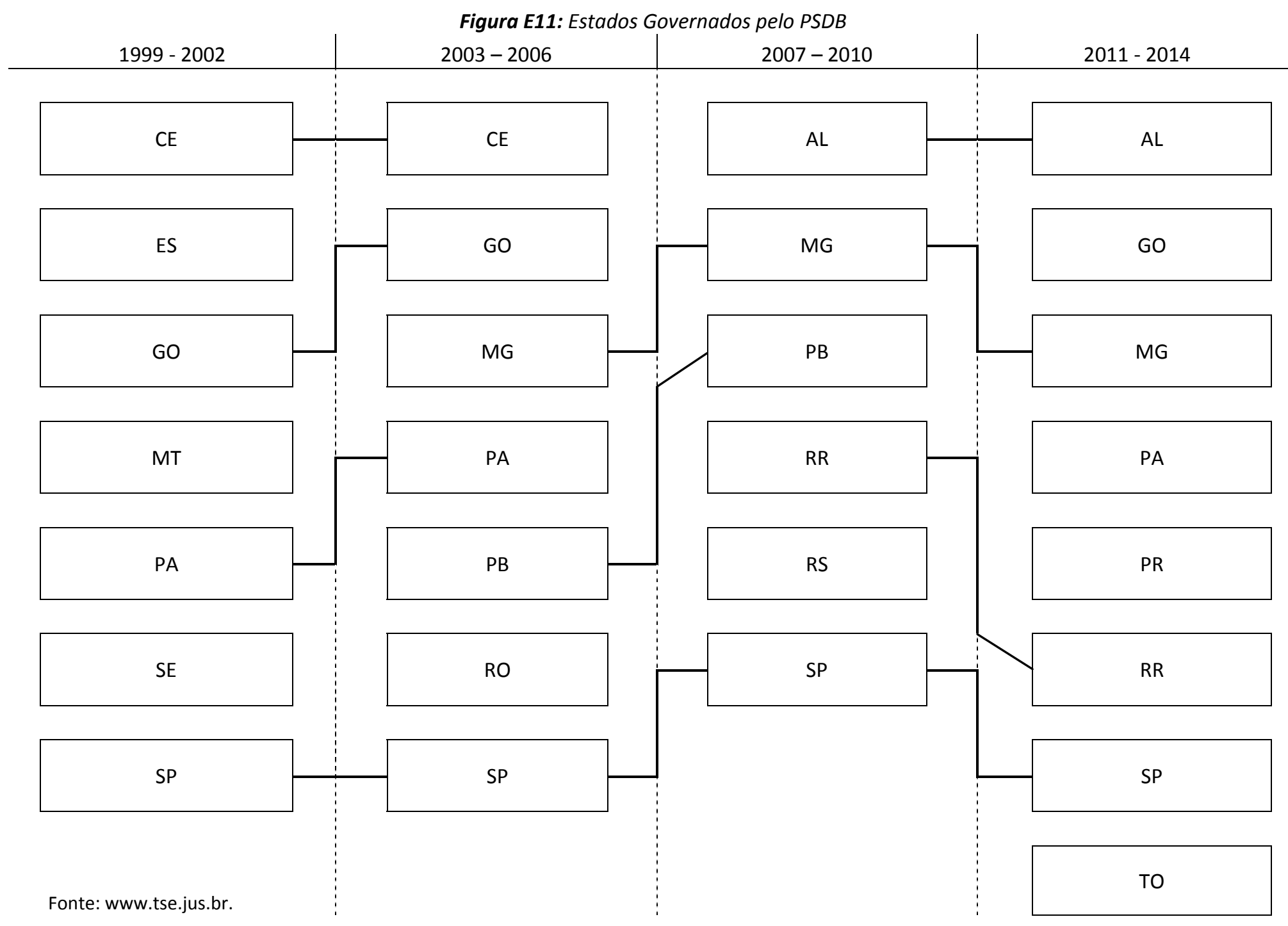




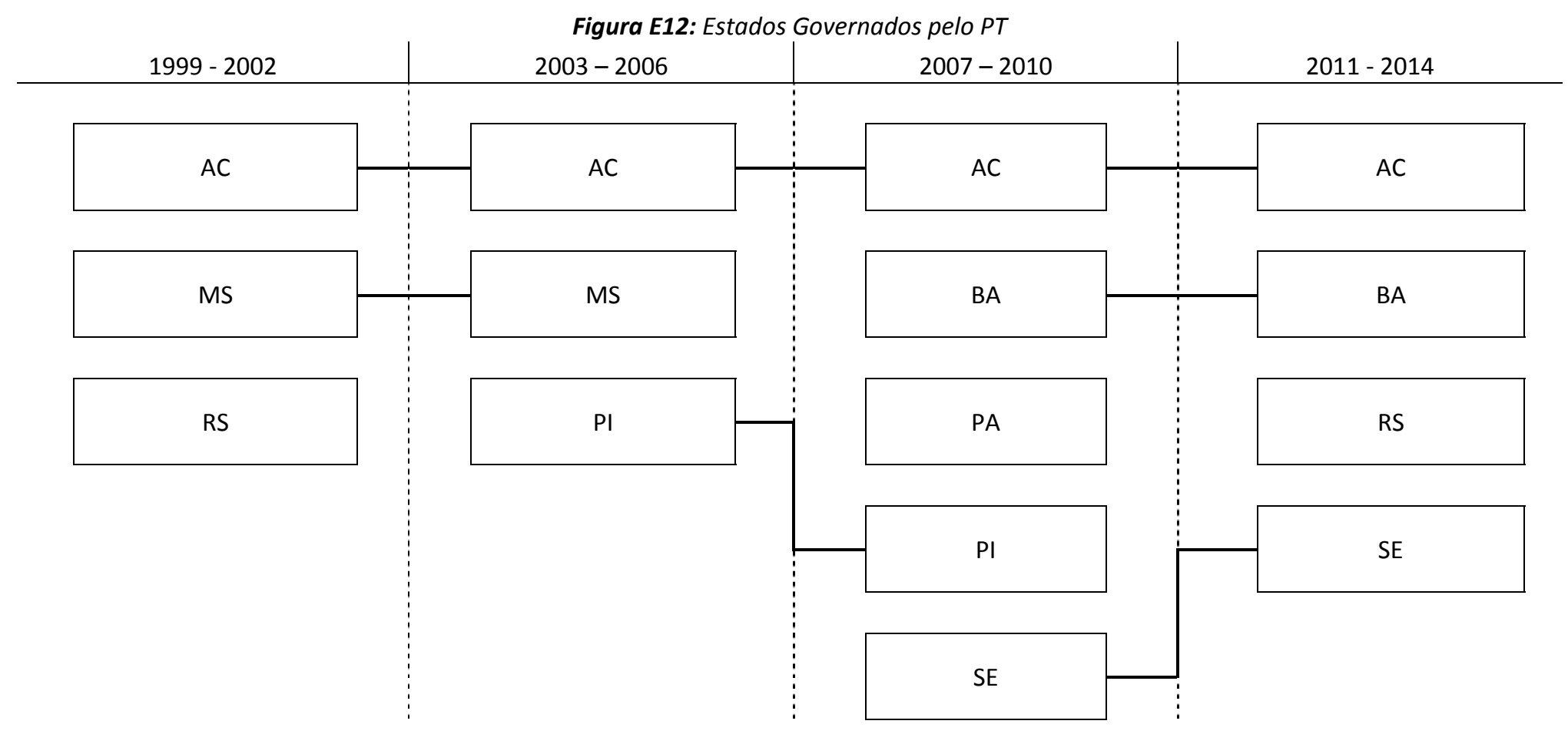

Fonte: www.tse.jus.br. 